\title{
Strategies for sustainable professional development programs to promote effective pedagogical use of instructional technology in teaching
}

\author{
Karla R. Assis Cezarino \\ West Virginia University
}

Follow this and additional works at: https://researchrepository.wvu.edu/etd

\section{Recommended Citation}

Assis Cezarino, Karla R., "Strategies for sustainable professional development programs to promote effective pedagogical use of instructional technology in teaching" (2004). Graduate Theses, Dissertations, and Problem Reports. 2646.

https://researchrepository.wvu.edu/etd/2646

This Dissertation is protected by copyright and/or related rights. It has been brought to you by the The Research Repository @ WVU with permission from the rights-holder(s). You are free to use this Dissertation in any way that is permitted by the copyright and related rights legislation that applies to your use. For other uses you must obtain permission from the rights-holder(s) directly, unless additional rights are indicated by a Creative Commons license in the record and/ or on the work itself. This Dissertation has been accepted for inclusion in WVU Graduate Theses, Dissertations, and Problem Reports collection by an authorized administrator of The Research Repository @ WVU.

For more information, please contact researchrepository@mail.wvu.edu. 
Strategies for Sustainable Professional Development Programs to Promote Effective Pedagogical Use of Instructional Technology in Teaching

Karla R. Assis Cezarino

\author{
Dissertation submitted to the \\ College of Human Resources and Education \\ at West Virginia University \\ in partial fulfillment of the requirements \\ for the degree of
}

\author{
Doctor of Education \\ in \\ Technology Education
}

John Wells, Ph.D., Chair Judy Abbott, Ph.D.

Cheryl Prichard, Ed.D.

Neal Shambaugh, Ph.D.

Richard Walls, Ph.D.

Department of Advanced Educational Studies

\author{
Morgantown, West Virginia \\ 2004
}

Keywords: Professional Development, High-Level Use of Technology, Instructional Technology, Inservice Training

Copyright 2004 Karla R. Assis Cezarino 


\title{
ABSTRACT \\ Strategies for Sustainable Professional Development Programs to Promote Effective Pedagogical Use of Instructional Technology in Teaching
}

\author{
Karla R. Assis Cezarino
}

The purpose of this study was to determine a set of common strategies employed by sustainable instructional technology professional development programs that are found to successfully promote educators' high-level use of technology in their teaching practice. Two questions guided this study: (a) Research Question 1: What do successful instructional technology professional development programs recognize as indicators of high-level use of technology?, and (b) Research Question 2: Which instructional technology professional development strategies successfully promote high-level use of instructional technology in participants' teaching practice?

An online questionnaire consisting of close-ended questions and open-ended questions was used as the means of data collection. The online questionnaire was completed by 70 instructional professional development programs' directors or their designees. The professional development programs participating in this study were awardees of PT3 1999 and 2000 implementation grants.

The data from the close-ended questions of the questionnaire were analyzed using central tendency measures and were used to answer to Research Question 1. For each survey's closeended questions there was a corresponding open-ended question. The open-ended questions were analyzed using qualitative content analysis and the data coming from this section of the questionnaire were used to answer to Research Question 2.

The results from the analysis of the close-ended section of the questionnaire indicated that the majority of instructional technology professional development programs participating in this study were successful in preparing their participants to address 22 out of the 27 indicators of high-level use of technology presented in this study. The analysis of the open-ended responses indicated that out of the 26 strategies mentioned by participants the most successfully used strategies across indicators were: Strategy 9: Appropriate Lesson/Learning Activity Development; Strategy 6: Presentation/Demo/Hands on; Strategy 1: Identifying/Defining Appropriate Use of IT; Strategy 3: Evaluation/Critique/Assessment; Strategy 14: ProblemBased Learning/ Project-Based Learning; and Strategy 26: Lesson Implementation. Each of the strategies had multiple approaches depending on factors as context and goals of the professional development programs participating in this study. Further study was recommended. 


\section{DEDICATION}

To the woman I most admire and love, my mom Alzenir, I am but a reflection of her kind soul and her immense strength. To my brothers, Rodrigo and Aleksandro, whose friendship, love and support helped me discover the true meaning of family. To my father, Joao Carlos, who has always encouraged my academic efforts. To my mother-in-law, Dona Elvira, for making me feel as a loved daughter since the first time we met. To the person whose eyes reflect my soul, my true and eternal love, my soul mate, my husband Herval. This dissertation would not be possible without all of the love and support from the people mentioned here.

Para a mulher que mais admiro e amo, minha mãe Alzenir, de quem sou somente um reflexo da sua alma bondosa e sua imensa força. Para meus irmãos, Rodrigo e Aleksandro, que através de seu amor e amizade me ajudaram a descobrir o significado real da palavra família. Para meu pai, João Carlos, que sempre incentivou a minha educação. Para minha sogra, Dona Elvira, por me fazer sentir como uma filha querida desde o primeiro momento que a conheci. Para a pessoa cujos olhos refletem a minha alma, meu verdadeiro e eterno amor, minha alma gêmea, meu esposo Herval. Sem o amor e o apoio de todas estas pessoas aqui mencionadas esta dissertação não seria uma realidade.

In memory of Francisco Freire (vovô), the man who showed me I had wings... $\&$

Maria Ines Iaquinta (Mara Maravilha) the wild butterfly who showed me how to fly.

Em memória de Francisco Freire (vovô) o homen que me mostrou que eu tinha asas... \&

Maria Inês Iaquinta (Mara Maravilha) a borboleta “doida” que me ensinou a voar. 


\section{ACKNOWLEDGEMENTS}

There are many things behind each word in this dissertation. Each word contains a universe of feelings and experiences that are not represented in its written form but that were felt by me and the people I love. In the process of writing this dissertation, I discovered the meaning of love, care, strength, support, and family. I understood the meaning of sacrifice and devotion. I was immersed in a universe of controversial feelings so far unknown to me. This dissertation is much more than an academic work; it is a portrait of my weaknesses and strengths that were revealed to me during its writing process.

This dissertation is a collaborative work of the many people who contributed in so many ways to its completion. I cannot visualize going through the process of writing it without the immense support of my committee members. I do not think there is a word yet to describe the deep gratitude I have for Dr. John Wells. His role as my advisor was exceeded in many different instances. I learned from him the meaning of devotion and love for the academic life. For the hours of enlightening discussions and guidance I cannot thank him enough. To his family who kindly shared his time with his graduate advisees, I cannot express how grateful I am.

I was very blessed for having such wonderful committee members who are extraordinary professors besides being phenomenal human beings. Therefore, I would like to express my deepest gratitude to Dr. Cheryl Prichard for her kindness and caring. Her support made me see the light at the end of the tunnel. For being there for me and devoting so many hours in guiding me through the process of my dissertation I will always be thankful. Dr. Judy Abbott, I was blessed for having her as a professor and as a committee member for my thesis and now for my dissertation. Her classes inspired me to rediscover the meaning of education and helped me realize my true passion for teaching. My deepest gratitude to Dr. Richard Walls who showed me that even graduate classes can be fun and that the true educator is the one who does not complicate what is simple. Thank you for pushing me to aim for the close to perfection in whatever I do. Finally, I would like to thank Dr. Neal Shambaugh, his support was immeasurable. I have to thank him for caring so much and helping me to believe in myself. To

all my committee members I consider you models whose footstep I will be proud to follow. I am very blessed for having you as part of my life. I will miss each of you immensely. 
My special thanks to Dr. David J. Ayersman, I cannot thank him enough for taking the time to help me to make the online version of the questionnaire possible. His help was an essential to the conduction of this study.

I would also want to express my gratitude to the Council of International Program for making possible my first coming to the USA. My deepest gratitude to the staff and friends of the Intense English Program at West Virginia University, working with such wonderful people was a blessing. I am eternally indebt to the Teaching and Technology Learning Center and all Human Resources and Education professors and staff. Special thanks to Tim Mitchem, my boss, and dearest friend. I am truly thankful for all his support and understanding. Working with him added a lot to my professional life. To my co-workers Smiti, Angie, Rong Ye, Rodolfo, Francis and Ying Ying, my deepest gratitude for being there for me when I needed most.

I truly believe that we are but an extension of the many people who are part of our lives. To all these people who somehow contributed to whom I am today, although, your names are not written here you know who you are and I am eternally grateful. I would like to special thank the friends I made during the five years I have lived in Morgantown. To my dearest friend Lisa Dunn, thanks for brightening my days when what I could only see were dark clouds. My Turkish friend, Sabah Karayegen-Giraldo, you are one of a kind. I just want you to know that I am very blessed to have you as my friend. I never thought that I would find true friendship so far away from home. Raquel Alo, thank you for finding my laugh when I could not even smile. You are very special to me. Joao Neto, Carlos Eduardo, Sérgio and Circe for bringing so many happy moments to my and Herval's life. Marcia Franklin and Vana Blanker, we have lived so much during such a short time. I have learned so much from you two. I cannot thank you enough for letting me be part of your lives.

Special thanks to Dr. Sandra Dixon, whose Latin soul and passion for Brazilian culture have made me feel at home whenever in her company. I have learned so much just observing her kindness towards the world. Thanks for devoting so much of your time proofreading my dissertation. I am eternally in debt to you. You will always be considered part of my family.

To Marina and Eric Spears, my special thanks for supporting my efforts during the tough times. I will always be thankful for your friendship. To Patricia and Martinha for supporting me through the earlier days of my teaching practice, your guidance and friendship were really appreciated. 
I thank each of the friends I mentioned for not letting me be lonely even when I was alone. For bringing sunshine to the snow days, and for being just true friends... I would also thank all my family whose support and love made this dissertation possible.

Finally, my deepest gratitude to the participants of this study who took time from their busy schedules to complete this study's survey, their help and support were deeply appreciated.

Agradeço imensamente meus avós Antônio e Anna Ribeiro que encheram a minha vida de doces memórias e me deram a pessoa mais preciosa da minha vida, minha mãe Alzenir. Minha mãe é a heroína de minhas estórias é o porto seguro que sei sempre posso ancorar. Agradeço minha avó Penha por me mostrar a doçura nas pessoas. Agradeço especialmente meus irmãos por estarem sempre ao meu lado, e ao meu pai por sempre acreditar em mim. A família do meu esposo e aos seus amigos obrigado por me aceitar sem restrições. A minha sogra agradeço o carinho e o apoio imenso. Finalmente, agradeço ao meu amor, meu esposo Herval por me fazer entender o que é o amor cada vez que seus olhos encontram os meus. Te amo! 


\section{TABLE OF CONTENTS}

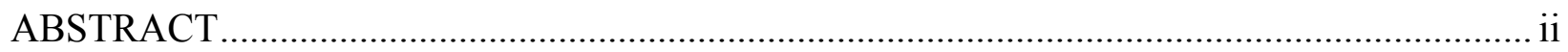

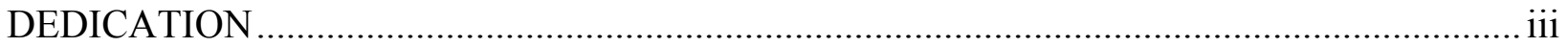

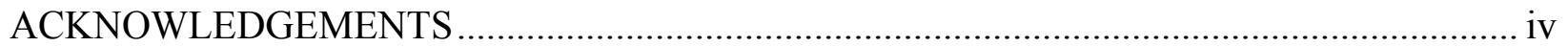

TABLE OF CONTENTS .................................................................................................... vii

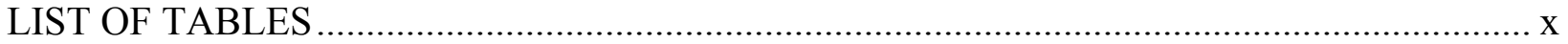

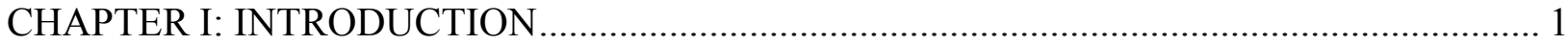

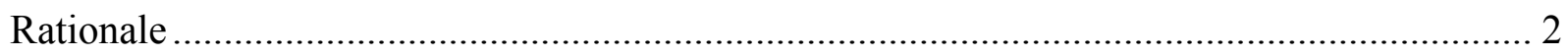

Successful Instructional Technology Professional Development Characteristics ................. 3

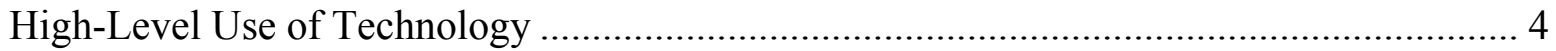

Instructional Professional Development Programs' Problems ........................................... 4

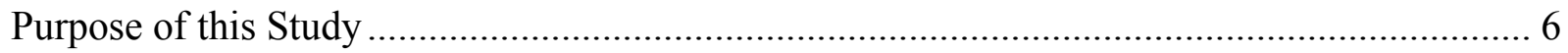

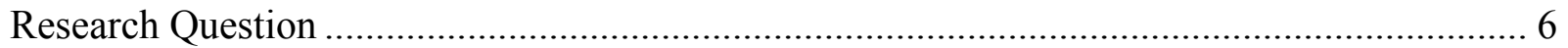

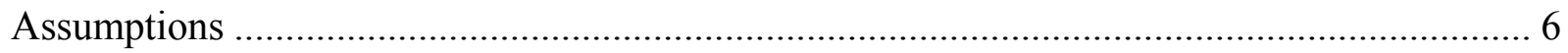

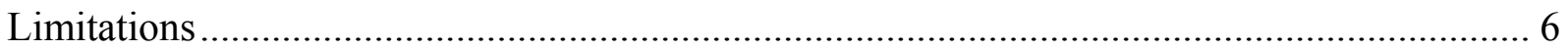

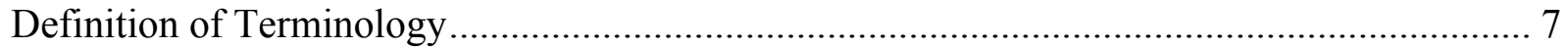

CHAPTER II: REVIEW OF LITERATURE …............................................................ 9

Pedagogical Principles and Instructional Technologies ................................................... 9

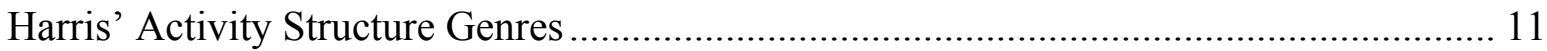

Indicators of High-level Use of Instructional Technology in Teaching .............................. 16

National Technology Standards for Teachers.............................................................. 19

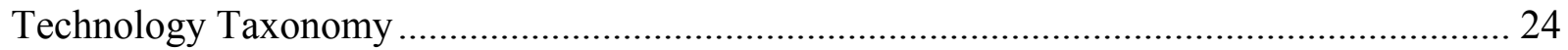

Research Findings about Characteristics of Effective and Successful Professional

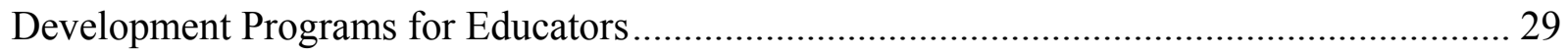

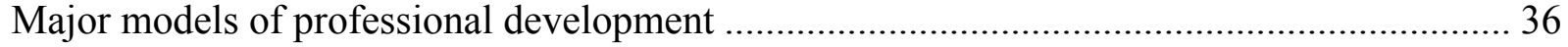

CHAPTER III: METHOD AND PROCEDURE ................................................................... 41

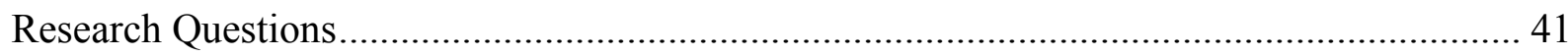

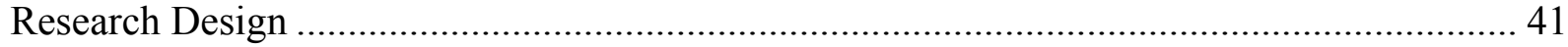

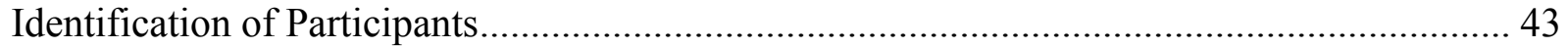

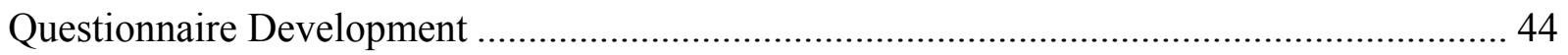




\section{TABLE OF CONTENTS (CONTINUED)}

High-Level Use of Technology and NETS for Teachers ..................................................... 45

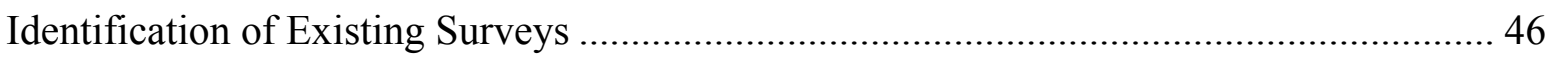

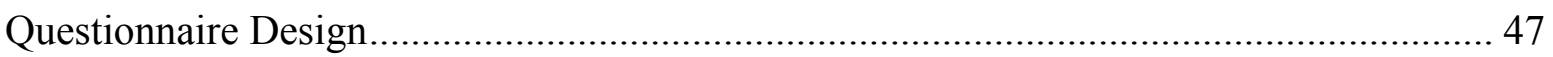

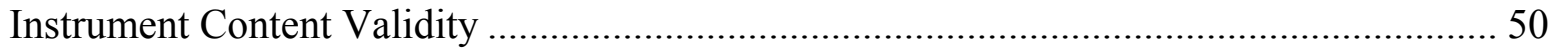

Posting on Password Protected University Server and Questionnaire Revisions................. 57

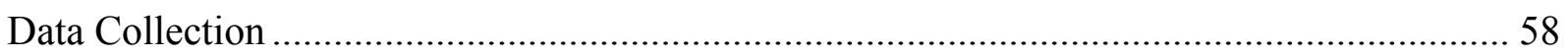

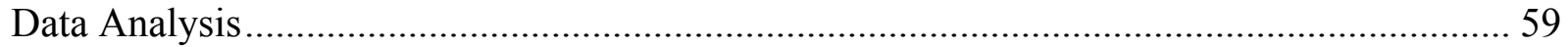

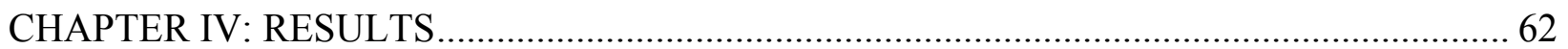

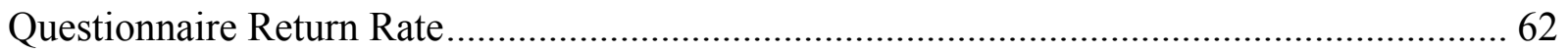

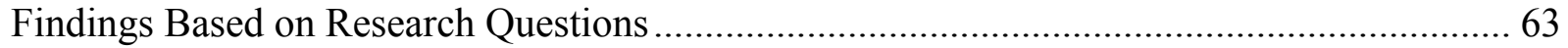

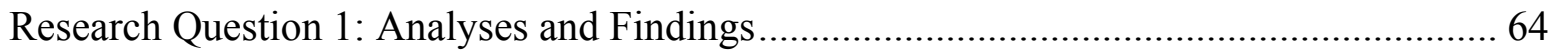

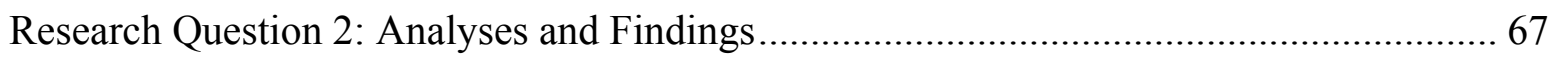

CHAPTER V: SUMMARY, DISCUSSION, AND RECOMMENDATIONS ............................. 89

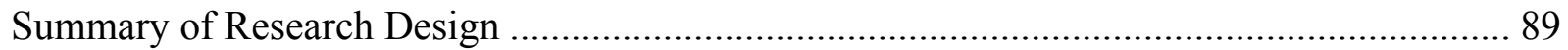

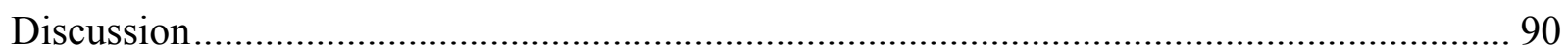

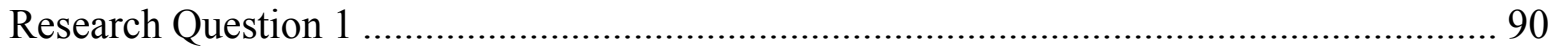

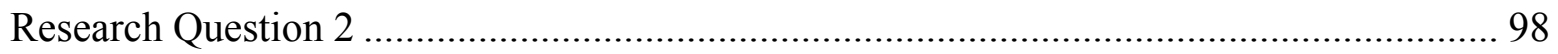

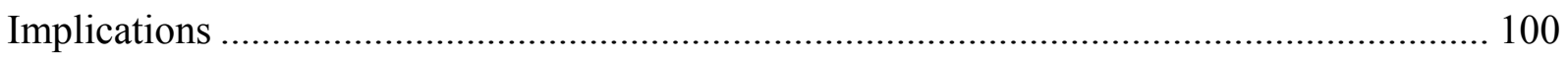

Recommendations for Further Research ................................................................... 102

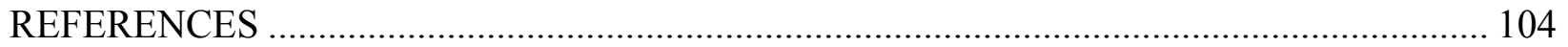

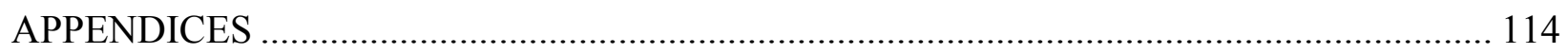

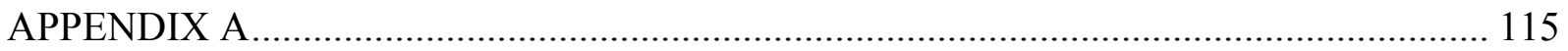

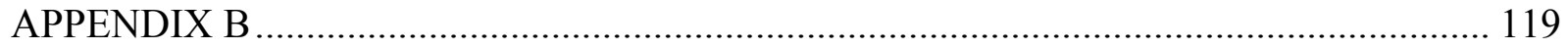

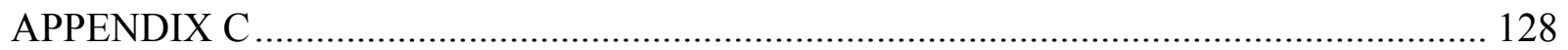

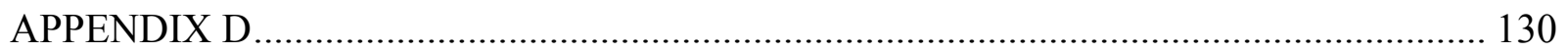

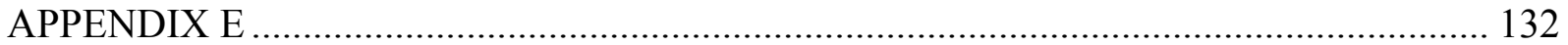

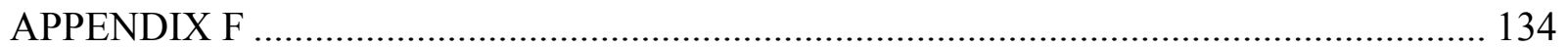

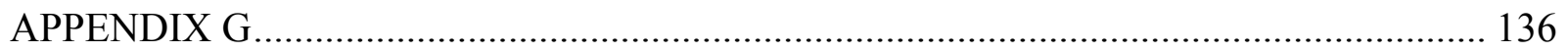

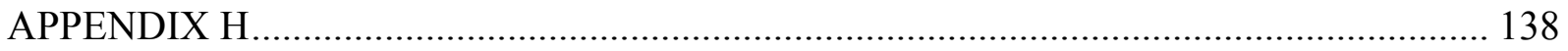

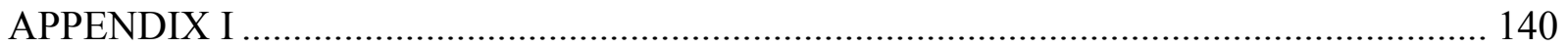




\section{TABLE OF CONTENTS (CONTINUED)}

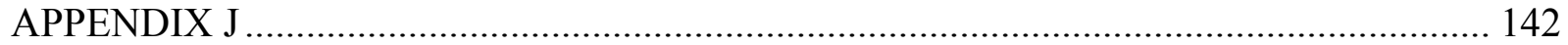

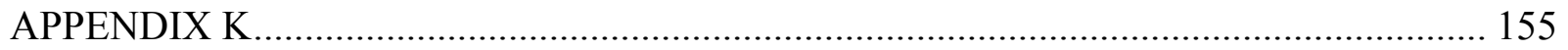

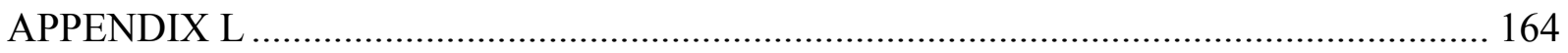

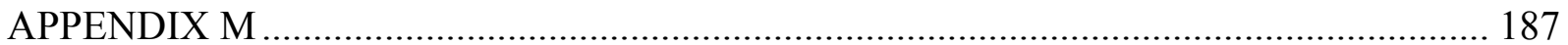

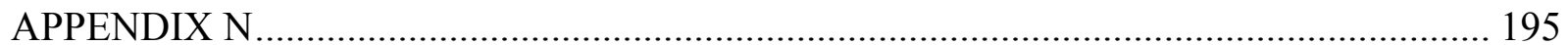

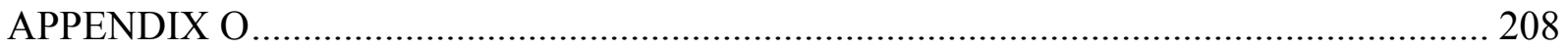




\section{LIST OF TABLES}

Table 1 : Judi Harris' (1998) Activity Structure..................................................................... 12

Table 2 : National Educational Technology Standards for Teachers ................................... 21

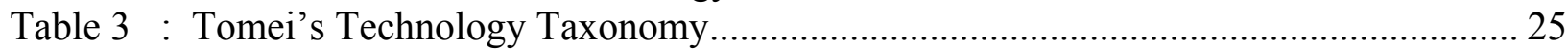

Table 4 : The Technology Domain ...................................................................................... 26

Table 5 : Methodology Overview ......................................................................................... 42

Table 6 : High-Level Use of Technology Categories and Questionnaire's Items (Before

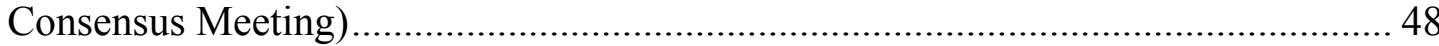

Table 7 : High-Leve Use of Technology Categories and Quesionnaire's Items (After

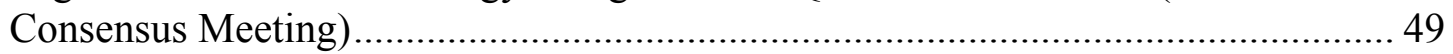

Table 8 : Results of Assessment of Questionnaire's Content Validity .................................... 53

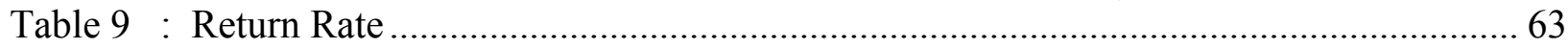

Table 10 : Recognized Indicators of High-Level Use of Technology .................................. 64

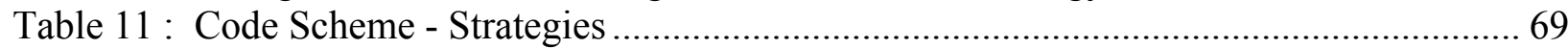

Table 12 : Number of Responses per Indicator ................................................................. 71

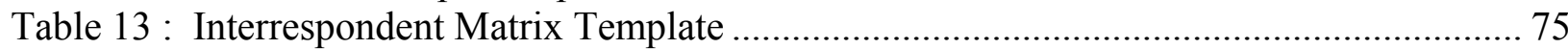

Table 14 : Example of Interrespondent Matrix Analysis ................................................... 75

Table 15 : Percentage of Strategies Used per Indicator ................................................... 78

Table 16: Summary of Frequency of Strategies Used per Ranges ....................................... 81

Table 17 : Weighted Values Assigned to the Range Intervals............................................... 82

Table 18: Weight Assigned to the Percentage of Strategies Used per Indicator ....................... 84

Table 19: Rank of Strategies Use Across Indicators and Within the Quartiles ....................... 86

Table 20 : Rank of the Top Six Used Strategies Across Indicators........................................ 87

Table 21 : Indicators Recognized by Professional Development Programs Aligned with NETs

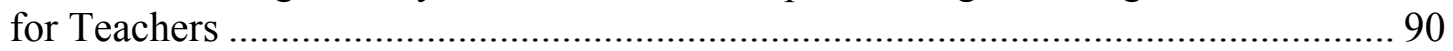

Table 22: NETS for Teachers not Covered by Professional Development Programs ............... 94

Table 23 : Indicators of High-Level Use of Technology not Addressed by Professional Development Programs 


\section{CHAPTER I: INTRODUCTION}

Educators have been facing what seems to be a never-ending battle to achieve a technological comfort level in their teaching practices. Technology imposes constant revision in the ways of best promoting learning in a content area, demanding educators to be more skilled decision makers (Roblyer \& Edwards, 2000; Tomei, 2002).

In the past 10 years, significant increases in the number of computers per student and in the number of schools that have access to the Internet could be seen throughout the United States (Barron, Kember, Harmers, \& Kalaydjian, 2003). Schools are spending millions of dollars on computers and software, yet "only 9 percent of their technology budgets go toward teacher preparation... and what limited preparation teachers do receive is still in the form of skills and competencies instead of curriculum application" (Tomei, 2002, p. 206).

The Web-Based Education Commission (2000) suggested that teachers have to feel comfortable with technology; they have to be able to envision the application of technology in their teaching in a natural way. If teachers are not prepared to use technology comfortably as a tool to support students' learning experience, their professional preparation cannot be considered successful for they could not help prepare their students to succeed in the Digital Age (CEO Forum on Education \& Technology, 2000).

Nevertheless, in most of the schools, although educators recognize the important role of technology in education, they do not feel well prepared to use it effectively as part of their teaching. Most educators cannot envision the implementation of instructional technology (IT) in a way that supports their teaching approach (North Central Regional Educational Laboratory, 2003; Web-Based Education Commission, 2000). 
As a result, there has been an increased focus on the importance of high quality professional development for educators. The US Department of Education (2000) has called attention to the fact that quality professional development programs are essential for educators to be able to keep up with the demands of today's society. According to Mouza, (2002-2003), "it is only through professional development that teachers can acquire the skills necessary to make the most of the digital resources available in their classroom" (p. 275).

Professional development programs for educators face a common problem of a top down design and the disconnection between what is learned during professional development programs and what is implemented in classroom practices (Guskey, 2000). It seems that most of the instructional technology professional development programs forget that top of the line computers and high speed Internet connection do not themselves promote learning, they are just tools that can be used to help facilitate the learning process. As Kleiman and Johnson (1998) state "the power of any tool is not inherent in the tool itself; it is a function of the user's ability to put the tool to good use for specific purpose" (para. 1).

\section{Rationale}

Cradler, Freeman, Cradler, and McNabb (2002) reported an increase in educators' interest for technology, and thus an increase in opportunities for learning the how, when and why of implementing technologies into their teaching. On the other hand, one of the findings from a study conducted by Lam (2000) was that the main reason for educators not using computers for teaching was a lack of knowledge about how to integrate computers in their respective subject areas. 


\section{Successful Instructional Technology Professional Development Characteristics}

Professional development programs for educators must meet educators' different needs and support them through the challenges that technology brings to their teaching, introduce to them the pedagogical issues related to the instructional technology tools; give them hands on experience on using the instructional technology tools, and guide the process of redefining or strengthening their teaching beliefs and practice (Kleiman \& Johnson, 1998). "Only ongoing teacher learning through professional development can make current teachers aware of changing expectations and validated, effective, teaching methods" (National Conference of State Legislatures, 2002, para. 1).

The importance of successful teachers' instructional technology training is to promote the implementation of technology in education and to "ensure that teachers are able to integrate technology into the curriculum to improve student achievement" (U. S. Department of Education, No Child Left Behind, 2000, para 2). A report by the North Central Regional Educational Laboratory (2003), suggests that educators need to understand the different ways in which technology can support their own pedagogical practice and belief.

Among the critical components of any faculty development plan suggested by Preparing Tomorrow's Teacher to Use Technology (2002) is the need for emphasis on the pedagogical aspect in the process of technology integration. As Harris (1998) pointed out "the tool in and of itself, no matter how powerful its features, cannot make learning happen. The teacher, no matter how technically competent, enters a related but distinct realm for inquiry when he or she plans for the educational application of any new tool" (p. 6). 


\section{High-Level Use of Technology}

The term "pedagogical use of technology" in this research implies the high-level use of technology in teaching. It refers to the use of technology as "a classroom tool for research, communication, productivity, and problem-solving" (Barron, et. al., 2003, p. 489). It is the use of technology for promoting critical thinking, "higher order, cognitive processes, alternative assessment schemes, interdisciplinary/integrated instruction, and/or the changing role of the teacher in the classroom" (Moersh, 2002, p. 12). The terms "high-level use of technology" and "pedagogical use of technology" are used interchangeably throughout the study.

\section{Instructional Professional Development Programs’ Problems}

There is consensus among some noted researchers (Harris, 1998; Mouza, 2002-2003; Roblyer \& Edwards, 2000; Tomei, 2002) in mentioning that practice with instructional technologies and an understanding of their pedagogical applications are essential to the success of any professional development program. However, "there has been little carryover into the classroom, and new technologies have remained on the periphery of school life, and been used only sporadically by teachers despite the high expectations of trainers, reformers and the teachers themselves" (Grant, 1996, para. 1). Unfortunately, most of the IT professional developments consider the integration of instructional technology tools into teaching as an obvious process that does not need to be addressed once the tools are mastered (Harris, 1998).

Mckenzie (2001) mentions that most of the IT professional development programs focus on the development and mastery of software rather than on the guidance of the effective integration of the technology being presented in the curriculum as part of the instruction practice. Although numerous studies have pointed out the importance of focusing on pedagogical principles when implementing technology into teaching, Mouza, (2002-2003) suggests, "teachers 
often feel uncomfortable using computers and are unaware of the teaching and learning pedagogies that computers and the Internet are able to support" (p. 273).

Almost two decades have passed since computers were first used in education. Today, in the U.S. more than 90 percent of schools have computers that are connected to the Internet (Web-Based Education Commission, 2000). However, educators still do not feel ready to use computers in a confident, creative and competent way, due most of the time to the lack of proper pedagogical training and technical support (Tomei, 2002).

One of the problems faced by professional development programs is the difficulty in determining "best practices" in this area since "what works always depends on where, when and with whom" (Guskey, 2002, p. 51). Although there are a number of studies (Crawford, 2003; Feist, 2003; Grant, 1996; Guskey, 2000) that list the overall characteristics of high quality professional development programs, there have been few systematic research efforts aimed at determining the relationship between these characteristics and educators' outcomes (e.g., classroom applications). Furthermore, not many systematic studies have been conducted focusing on the efficacy of the content and activities presented during a professional development program (Garet, Porter, Desimone, Birman, \& Yoon, 2001).

Educators at all levels face the problem of lack of proper preparation and support for efficient integration of technology in the classroom. The access to information on instructional professional developments' best practices could help guide the decisions about the strategies and activities to use when designing future instructional technology (IT) professional development programs (Brush, Glazewski, Rutowski, Berg, Stromfors, Van-Nest, Stock, \& Sutton, 2003; Seels, Campbell, \& Talsma, 2003). 
Although studies (Schrum, 1999; Sparks, 2002; U.S. Department of Education, 2000) have identified the characteristics of successful instructional technology professional development programs, none to this researcher's knowledge have determined strategies that can best guarantee the high-level use of technology in teachers' practice.

$$
\text { Purpose of this Study }
$$

The purpose of this study was to determine a set of common strategies employed by sustainable instructional technology professional development programs that are found to successfully promote educators' high-level use of technology in their teaching practice. Moreover, this research offers an initial resource for other instructional technology professional development programs to reflect upon when designing and defining their own strategies.

\section{Research Question}

The research questions guiding this study were:

1. What do successful instructional technology professional development programs recognize as indicators of high-level use of technology?

2. Which instructional technology professional development strategies successfully promote high-level use of instructional technology in participants' teaching practice?

$$
\text { Assumptions }
$$

The following assumption was made in this study:

1. The professional development programs participating in the study achieved their goal of preparing teachers who can integrate technology successfully as part of their teaching practice.

\section{Limitations}

This study was limited in the following ways: 
1. This study is restricted to Instructional Technology Professional Development in the USA.

2. The sample size does not allow generalizations.

\section{Definition of Terminology}

The following terms were used throughout the study:

Sustainable and Effective Professional Development: "is defined as those processes and activities designed to enhance the professional knowledge, skills, and attitudes of educators so that they might, in turn improve the learning of students...it is a process that is intentional, ongoing and systemic" (Guskey, 2000, p.16).

Instructional Technology: "Instructional technology is another instructional strategy another tool for teaching elementary, secondary or adult learner” (Tomei, 2002, p. 5). It “combines educational technology with learning strategies, developmental principles, and pedagogical ideals" (Tomei, 2002, p. 7).

Learning: "the process of gaining knowledge and/or expertise" (Knowles, Holton, \& Swanson, 1998, p. 17).

Learning Theory: "a set of constructs linking observed changes in performance with what is thought to bring about those changes" (Driscoll, 2000, p. 11).

Integrating Instructional Technology: "refers to the process of determining which electronic tools and which methods for implementing them are appropriate for given classroom situations and problems" (Roblyer \& Edwards, 2000, p. 8).

Pedagogy: "the functions and work of teaching" (Shambaugh \& Magliaro, 1997, p. 293). “A set of assumptions about learning and strategies for teaching” (Knowles, et. al., 1998, p. 36). 
High-level use of technology: term that is used interchangeably with pedagogical use of technology. It refers to the use of technology as "a classroom tool for research, communication, productivity, and problem-solving" (Barron, et. al., 2003, p. 489). It is the use of technology for promoting critical thinking, "higher-order cognitive processes, alternative assessment schemes, interdisciplinary/integrated instruction, and/or the changing role of the teacher in the classroom" (Moersh, 2002, p. 12).

Learning beliefs: "a set of convictions about what learning is, how it occurs, and ways to promote it in humans" (Shambaugh \& Magliaro, 1997, p. 292).

Critical Thinking: "involves the dynamic reorganization of knowledge in meaningful and usable ways. It involves three general skills: evaluating, analyzing, and connecting” (Jonassen, 2000, p. 27).

Interactive Professional Development Program: are programs that "encourage reflection, provide control, direct attention, and add dimension to content” (Driscoll, 1998, p. 99).

Education: "is an activity undertaken or initiated by one or more agents that is designed to effect changes in the knowledge, skill, and attitudes of individuals, groups, or communities" (Knowles, et. al., 1998, p. 10). 


\section{CHAPTER II: REVIEW OF LITERATURE}

\section{Pedagogical Principles and Instructional Technologies}

According to Trilling and Hood (1999), in the Industrial Age learning happened through lectures, facts, drills, rules and procedures, in today's Information Age learning happens through projects and problems, inquiry and design, discovery, and invention. In today's educational system various methods and theories of learning are applied in different circumstances to address students' unique needs. Old and new methods are used with a focus on problem-based collaborative activities that reflect students' realities and make their learning experience more relevant (Trilling \& Hood, 1999).

Educators are still dealing with the problems of a great number of choices offered by technology and the changing in the roles of teachers and learners imposed by technology use. Thus, often there is not enough time left for the discussion of the pedagogical issues and implications related to the use of a certain instructional technology tool in their classroom (Firdyiwek, 1999). Although technology is seen as a great learning tool, educators must remember that "it's the practice and the results, not the tools that make a difference" (Trilling $\&$ Hood, 1999, p. 12).

Educators must perceive the contribution of technology to their teaching practice and the rationale for the use of technology if they are to allocate time and resources on the planning and implementation of instructional technology in their instruction (Roblyer \& Edwards, 2000). Among the reasons for educators to use technology are: (a) the motivational aspect of technology, (b) the contribution that technology can make in the creation of a learner-centered environment, (c) the support that technology can give to new instructional practices such as collaborative learning, problem solving, and higher-order skills, (d) the assistance that 
technology can provide to increase teachers' productivity, and (e) the need to prepare students' with the skills demanded by today's society (Roblyer \& Edwards, 2000).

The education system has been compelled to change in order to reflect the needs of today's society. In this transition, educators have questioned their own instructional practices and teaching beliefs. Although changes in education are seen as a natural process there is a lot of controversy in defining the best way to promote these changes in order to enhance learning (Roblyer \& Edwards, 2000).

As a result three distinctive lines of thoughts have arisen: (a) directed instruction: is based primarily on behaviorist and information processing theories and posits that "learning is transmitted knowledge, teacher should be teacher-directed, systematic and structured; and that discovery learning is too unstructured and unsystematic" (Roblyer \& Edwards, 2000, p. 50). The directed instruction model "emphasizes individualized environment in which information is presented in a clearly sequenced series of explicit instructions with feedback, reinforcement, and statistically valid and reliable testes" (Firdyiwek, 1999, p. 30); (b) constructivist: is based on cognitive and constructivist theories, and suggests that "leaning is constructed knowledge, teaching should let students participate in activities that are meaningful so they can generate their own knowledge, and that directed instruction is too rigid and teacher-centered" (Roblyer \& Edwards, 2000, p. 50). The constructivist model "emphasizes interactivity as a way of developing a general and unified understanding of a domain and favors organizing information to match the developmental stages of the learner. Assessment, involves performance and is relative to the background and developmental stage of the learner" (Firdyiwek, 1999, p. 30); (c) humanist: is based on the belief that "learning is a two-step process involving the acquisition of knowledge followed by individual personalization" (Tomei, 1997, p. 57). The teacher has to 
promote a classroom environment free of threats with abundance of materials from which students could choose to build up their own learning.

According to Roblyer and Edwards (2000) "drill and practice and tutorials are associated only with directed instruction; most others (problem solving, multimedia production, Web-based learning) can enhance either directed instruction or constructivist learning, depending on how they are used" (p. 49). Tomei (1997) adds to this thought by mentioning that instructional technologies such as audio and video conferencing can be used in the humanistic level to enhance and encourage interpersonal skills.

Therefore, it is educators' responsibility to choose the instructional technology tool that will best promote students' learning based on their own beliefs and judgment of how learning should take place. A mixed approach merging directed, constructivist and humanist activities is advisable in order to address students' different needs (Roblyer \& Edwards, 2000).

Unfortunately, most of the teachers do not know how to integrate technology in a way that would reflect their teaching beliefs. The assumption that the availability of resources would naturally lead to their integration into the teaching and learning environment has been proved wrong (Earle, 2002).

\section{Harris’ Activity Structure Genres}

Harris (1998) states that as with any other educational tool computer-mediated communication (CMC) instructional technologies tools can only make a difference in the learning and teaching process if they are chosen wisely based on careful thinking by the educator in answering a simple question: Is using instructional technology worth it? Harris (1998) mentions that this question can only be answered after answering the following ones: Is this computer instructional technology tool going to allow my students to do something that they 
could not do before? Or is it going to allow my students to do better something that they would do before using other educational tools? If the answer for one of these questions is yes, and if the educator can pedagogically sustain it, then the implementation of instructional technology in the educator's class is likely to be successful and worth the time, effort and expense.

Harris (1998) classifies the computer-mediated communication tools according to the kind of activity that each one can promote. It is important to notice though that a $\mathrm{CMC}$ instructional technology tool can have as many uses as the imagination and creativity of an educator. Harris (1998) explores computer-mediated communication tools and places them under three major categories: (a) interpersonal exchange, (b) information collection and analysis, and (c) problem solving. In an overview of these categories, the activities and tools that go under them are presented below:

Table 1

Judi Harris' (1998) Activity Structure

\section{Interpersonal Exchange}

Interpersonal Exchanges are those activities in which individuals communicate electronically with other individuals, with another group, or when groups communicate electronically with other groups.

Key Pals $\quad$ Electronic (email, chat, etc.) communication between individual students who attend different schools, or who live in different parts of the state, country, or world.

Global Electronic communication between groups of students, usually two or more Classrooms classrooms, about topics of common interest 
Table 1 (continued)

Judi Harris' (1998) Activity Structure

Electronic Inviting authors, teachers, scientists, or other professionals who appear

Appearances online to answer student questions or participate in discussions relevant to their own professional lives

Telementoring Subject area specialists act as "online" mentors for students

Question \& Brief communication from students to an "online" expert asking a quick, Answer specific question

$\underline{\text { Activities }}$

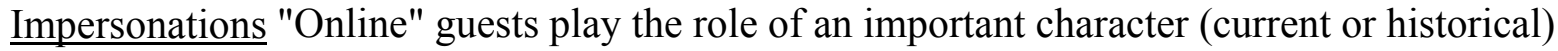
and communicate with students

\section{Information Collection and Analysis}

Information Collection and Analysis activities are those that involve students collecting, compiling, and comparing different types of interesting information.

Information Students send or receive information such as local weather conditions, book

Exchanges reviews, favorite quotations, recipes, etc.

Database Students gather or receive information and put it into an online database

Creation where it is available for students in other schools to use 
Table 1 (continued)

Judi Harris' (1998) Activity Structure

Electronic Students create online publications, such as a newspaper, literary magazines,

Publishing electronic journals, or ethnic cookbooks

Telefieldtrips Students electronically "tag along" on fieldtrips with other students in far away places. Students participate by emailing questions to those taking the fieldtrip, who then send back pictures, data and reports about the trip.

Pooled Data Students collect information on a specific topic from students and classes Analysis around the world, analyze it to find patterns, similarities, or differences, and then report their findings online

\section{Problem Solving}

Problem Solving activities promote critical thinking, collaboration, and problem-based learning.

Information Students are presented with a problem and then given clues to help locate

Searches important online information they will use to solve it

Peer Feedback Students share their work (compositions, art, design plans, projects) online

Activities with other students or subject area experts who are asked to provide constructive feedback

Parallel Students in several different locations are electronically presented with a

Problem similar problem, which they must solve independently using any and all

Solving resources available to them. The different approaches students used to solved the problem are then shared and compared. 
Table 1 (continued)

Judi Harris’ (1998) Activity Structure

Sequential Students electronically share in the creation of a new document (story, poem,

Problem art piece, etc.) by adding a part to it and then passing it on to others in

Solving different locations around the world

Telepresent Students in different geographical locations around the world work together

$\underline{\text { Problem }} \quad$ electronically (asynchronously or real-time) on a common project using

Solving many types of multimedia, from remote sensing to chat

Simulations Students participate in real-time collaborations that simulate actual/fictional events such as a space shuttle launch, Mars mission, United Nations meeting, or interactive mathematical modeling software

Social Action Students around the world focus on real and immediate global problems and Projects together take action on solutions to these social problems

Note: From “Virtual Architecture: Designing and Directing Curriculum-based Telecomputing” by J. Harris, 1998, International Society for Technology in Education (ISTE) as presented on http://www.trek-

21.wvu.edu/html/support/IT_exemplar.htm

In sum, when choosing the instructional technology for a certain activity, educators must focus on the content and purpose of the activity, aiming effective instructional practice. "The focus of integration is on pedagogy - effective practices for teaching and learning. Teachers need to be able to make choices about technology integration without becoming technocentric by placing undue emphasis on the technology for its own sake without connections to learning and the curriculum" (Earle, 2002, p. 10). 
Indicators of High-level Use of Instructional Technology in Teaching

According to the results from a study conducted by the International Society for Technology in Education (ISTE), commissioned by the Milken Exchange on Education Technology, "the technology infrastructure of education has increased more quickly than the incorporation of IT tools into teaching and learning” (Moursund \& Bielefeldt, 1999, p.2).

Although there is a great range of literature that address the problem of the lack of highlevel use of technology in teaching (Moursund \& Bielefeldt, 1999; Office of Technology Assessment, 1995) there is not a clear guideline of what the indicators of high-level use of technology might be. To address this problem a review of the literature surrounding the indicators of high-level use of technology was conducted. From this review high-level use of technology may be organized in 5 main categories (Boettcher, 2003; Bull, Bull, Cochran, \& Bell, 2002; Cradler, 2003; Earle, 2002; Harris, 1998; International Society for Technology Education [ISTE], 2000; Jonassen, 2000; Keefe, 2003; Kimball, Cohen, Dimmick, \& Mills, 2003-2004; McGrath, 2004; Mckenzie, 2002; Moursund \& Bielefeldt, 1999; Roblyer \& Edwards, 2000; Salomon, 2002; Thombs, 2003; Tomei, 1997; Trilling \& Hood, 1999; Woodell \& Garofoli, 2003).

1. Learner-centered: teachers use technology to promote hands on learning and learners' independence to explore and learn in an active way. Promoting learning through the access, interpretation, organization, and representation of information in a way that reflects students' own understanding of the information available to them.The ITs used by the learners give them the control over their own learning offering endless possibilities for learners to construct their learning experiences. Technology is used to engage learners in activities that lead them to the creation of their own technology-based product, 
promoting creativity, self-expression, and feelings of self-efficacy. Different ITs are offered to support different learning styles and needs, which also address students with limited English proficiency, gifted students, and students physically or mentally impaired.

2. Community of learners: teachers use technology as a facilitator of the human and social aspects of learning, creating an atmosphere that favors the interpersonal relation among the learners through collaborative work. Favoring the creation of knowledge based communities, in which learners articulate and negotiate the understanding of a subject and the use of technology to solve authentic problems related to the subject area. Teachers can also use technology to help bridge cultural differences and increase the students' understanding of the issues concerning a multicultural society. Encouraging and supporting the understanding of others beliefs and world perspectives. They can offer different opportunities for students to "craft effective communications in a variety of media for diverse audiences" (Trilling \& Hood, 1999, p.8). Instructional technology can be used to encourage conversations and discussions, offering an environment where learners can collaborate, argue and build consensus.

3. High-order thinking skills: teachers choose the instructional technology that would best help students to reorganize "knowledge in meaningful and usable ways. It involves three general skills: evaluating, analyzing, and connecting” (Jonassen, 2000, p. 27).

Technology is used to promote authentic learning tasks offering a learning environment that gives "a wide variety of contextualized opportunities for discovery, inquiry, design, practice, instruction, and constructive exploration" (Trilling \& Hood, 1999, p. 9). Teachers "must respect and encourage critical thinking and personal knowledge 
construction as meaningful goals" using technology to motivate students to engage in thinking and learning activities that reflect students' realities" (Jonassen, 2000, p. 278). ITs are used to guide their students to define their projects and to establish the project's evaluation criteria helping them to refine their problem solving skills and their ability to work collaboratively. Most of the time project-based learning involves cross-curricula activities offering learners the possibility of refining their knowledge and understanding about the content they are studying.

4. Appropriate use of instructional technology: Teachers use technology as a means to establish contact with other teachers and experts in the field in order to exchange ideas and thoughts about teaching, sharing their experiences, thus, broadening their horizons and becoming lifelong learners. They critically evaluate and choose the technology that best addresses their instructional goals answering to the whys and hows of the use of a specific IT as part of a learning activity. Teachers use technology as a tool for supporting the students' learning experiences. ITs that best support the achievement of a certain curriculum goal are chosen as part of content related activities to facilitate students' learning process.

5. Assessment: Teachers use different measures to evaluate students' technology-based products.

Instructional technology professional development programs play a crucial role in shaping the next generations' pedagogical use of technology. The focus of any instructional technology professional development should include the development of awareness of the importance of building activities that incorporate the high-level use of technology in the classroom. As stated by Bober (2002) “A teacher whose technology training has positively 
influenced pedagogy knows how to manage instructional time, how to ensure equitable access, how to encourage student initiative. Thinking about professional development as constructivist in nature and competency-based can dramatically alters how we plan for and what we expect from technology training" (p. 96).

\section{National Technology Standards for Teachers}

Federal funds have been allocated to equip schools to cope with the changes of a technological society. Most of schools have now access to computers and the Internet. However, few of them know how to use technology as an instructional tool to enhance instruction. The need for parameters in evaluating the use of technology in the classroom and the technology skills that are important for teachers to acquire have been the focus of many grant funders, specially the federal government (Bielefeldt, 2002; Bober, 2002). One way to address the need of high-quality teacher training has been the development of state, local and national standards concerning the integration of technology in the classroom (Moursund \& Bielefeldt, 1999).

In 1989 International Society for Technology Education (ISTE) was created having among its goals the establishment of technology standards for teachers (Roblyer, 2003). In 1998, the first National Educational Technology Standards (NETS) for students were established. In 2000, "with funding from the U.S. Department of Education PT3 grant and NETS Partners, NETS for teachers are reviewed and revised" (Roblyer, 2003). Later that year, the ISTE releases NETS for teachers. NETS for administrators were released in 2001.

In 1990, ISTE became a member of the National Council for the Accreditation of Teacher Education (NCATE). The NCATE is responsible for certifying teacher preparation programs in colleges and universities throughout the United States. "NCATE 2000 requires the conceptual framework to address six indicators specified in the NCATE standards. One of these 
indicators is "Commitment to Technology." One way a teacher education program can demonstrate its commitment to technology is by providing evidence that its graduates can meet the NETS for Teachers" (Roblyer, 2003, p. 10). Moreover, international well-known organizations such as UNESCO is adopting NETS for teachers and administrators and translating them into eight languages to be distributed among the 185 nations that are members of UNESCO (Roblyer, 2003).

The National Educational Technology Standards (NETS) for teachers are aligned with a related set of NETS for students (Bielefeldt, 2002; Roblyer, 2003). "At the state level, 48 of the 51 states have adopted, adapted, aligned with, or otherwise referenced at least one set of standards in their state technology plans, certification, licensure, curriculum plans, assessment plans, or other official state documents" (International Society for Technology in Education [ISTE], 2003a, para 1).

The focus of this study is on instructional technology professional development programs and the strategies they use to prepare teachers to integrate technology into the classroom. The NETS for teachers were designed having preservice teachers in mind, but it also suitable for inservice teachers. The goal is to have every teacher candidate meet the national technology educational standards. The standards were designed to be very general allowing customizations in order to fit the different state, university or district realities (ISTE, 2000). An overview of NETS for teachers is provided on Table 2. 
Table 2

National Educational Technology Standards for Teachers

\section{Technology Operations and Concepts}

Teachers demonstrate a sound understanding of technology operations and concepts. Teachers:

A. demonstrate introductory knowledge, skills, and understanding of concepts related to technology (as described in the ISTE National Educational Technology Standards for Students).

B. demonstrate continual growth in technology knowledge and skills to stay abreast of current and emerging technologies.

\section{Planning and Designing Learning Environments and Experiences}

Teachers plan and design effective learning environments and experiences supported by technology. Teachers:

A. design developmentally appropriate learning opportunities that apply technology-enhanced instructional strategies to support the diverse needs of learners.

B. apply current research on teaching and learning with technology when planning learning environments and experiences.

C. identify and locate technology resources and evaluate them for accuracy and suitability.

D. plan for the management of technology resources within the context of learning activities.

E. plan strategies to manage student learning in a technology-enhanced environment. 
Table 2 (continued)

National Educational Technology Standards for Teachers

\section{Teaching, Learning, and the Curriculum}

Teachers implement curriculum plans that include methods and strategies for applying technology to maximize student learning. Teachers:

A. facilitate technology-enhanced experiences that address content standards and student technology standards.

B. use technology to support learner-centered strategies that address the diverse needs of students.

C. apply technology to develop students' higher-order skills and creativity.

D. manage student learning activities in a technology-enhanced environment.

\section{Assessment and Evaluation}

Teachers apply technology to facilitate a variety of effective assessment and evaluation strategies. Teachers:

A. apply technology in assessing student learning of subject matter using a variety of assessment techniques.

B. use technology resources to collect and analyze data, interpret results, and communicate findings to improve instructional practice and maximize student learning.

C. apply multiple methods of evaluation to determine students' appropriate use of technology resources for learning, communication, and productivity. 
Table 2 (continued)

National Educational Technology Standards for Teachers

\section{Productivity and Professional Practice}

Teachers use technology to enhance their productivity and professional practice. Teachers:

A. use technology resources to engage in ongoing professional development and lifelong learning.

B. continually evaluate and reflect on professional practice to make informed decisions regarding the use of technology in support of student learning.

C. apply technology to increase productivity.

D. use technology to communicate and collaborate with peers, parents, and the larger community in order to nurture student learning.

\section{Social, Ethical, Legal, and Human Issues}

Teachers understand the social, ethical, legal, and human issues surrounding the use of technology in PK-12 schools and apply that understanding in practice. Teachers:

A. model and teach legal and ethical practice related to technology use.

B. apply technology resources to enable and empower learners with diverse backgrounds, characteristics, and abilities.

C. identify and use technology resources that affirm diversity.

D. promote safe and healthy use of technology resources.

E. facilitate equitable access to technology resources for all students.

Note: Reprinted with permission from National Educational Technology Standards for Teachers - Preparing Teachers to Use Technology, copyright (C) 2002, ISTE International Society for Technology in Education), 800.336.51.91 (U.S. \& Canada) or 541.302.3777 (International), iste@,iste.org, www.iste.org. All rights reserved. Permission does not constitute an endorsement by ISTE. 
According to Bober (2002) "NETS for teachers do not presently include strategies for measuring competence or attainment of standards or advocate training interventions that promote competence or proficiency. The path to excellence, whether pre-service or in-service, is left to individual schools, districts, and states to fashion" (p. 98). Therefore this study will offer suggestions of strategies that could be used in training interventions to promote high-level use o technology in teaching practice and thus addressing in a way standards II to VI of NETS for teachers.

\section{Technology Taxonomy}

According to Tomei (2002) the chances of establishing clear and doable objectives are increased when teachers use taxonomy to guide the objectives writing process. Therefore, Tomei (2002) developed the Technology Taxonomy based on Bloom's Cognitive Domain Taxonomy, Krathwohl's Affective Domain Taxonomy, and Kibler, Baker, and Miles' Psychomotor Domain Taxonomy.

The result is a six level technology taxonomy: (a) level one: technology for literacy, (b) level two: technology for collaboration, (c) level three: technology for decision-making, (d) level four: technology for infusion, (e) level five: technology for integration, (f) level six: tech-ology (Tomei, 2003). The levels of the Technology Taxonomy are interrelated. According to Tomei (2002) "the sooner we adopt a taxonomy for instructional technology and begin to rely on a new directory of action verbs to classify our technology-based learning objectives, the sooner we will ensure that technology mature into a successful teaching and learning strategy in its own right" (p.74). Below is the overview of Tomei's (2003) Technology Taxonomy: 
Table 3

Tomei's Technology Taxonomy

\begin{tabular}{|c|c|}
\hline Taxonomy Classification & Definition of the Level of the Technology Taxonomy \\
\hline $\begin{array}{c}\text { Literacy } \\
\text { Understanding Technology }\end{array}$ & $\begin{array}{l}\text { Level 1.0 The minimum degree of competency expected of } \\
\text { teachers and students with respect to technology, computers, } \\
\text { educational programs, office productivity software, the Internet, } \\
\text { and their synergistic effectiveness as a learning strategy. }\end{array}$ \\
\hline $\begin{array}{l}\text { Collaboration } \\
\text { Sharing Ideas }\end{array}$ & $\begin{array}{l}\text { Level 2.0 The ability to employ technology for effective } \\
\text { interpersonal interaction. }\end{array}$ \\
\hline $\begin{array}{l}\text { Decision-Making } \\
\text { Solving Problems }\end{array}$ & $\begin{array}{l}\text { Level 3.0 Ability to use technology in new and concrete } \\
\text { situations to analyze, assess, and judge. }\end{array}$ \\
\hline $\begin{array}{c}\text { Infusion } \\
\text { Learning with Technology }\end{array}$ & $\begin{array}{l}\text { Level 4.0 Identification, harvesting, and application of existing } \\
\text { technology to unique learning situations. }\end{array}$ \\
\hline $\begin{array}{c}\text { Integration } \\
\text { Teaching with Technology }\end{array}$ & $\begin{array}{l}\text { Level 5.0 The creation of new technology-based materials, } \\
\text { combining otherwise disparate technologies to teach. }\end{array}$ \\
\hline $\begin{array}{l}\text { Tech-ology } \\
\text { The Study of Technology }\end{array}$ & $\begin{array}{l}\text { Level 6.0 The ability to judge the universal impact, shared } \\
\text { values, and social implications of technology use and its } \\
\text { influence on teaching and learning. }\end{array}$ \\
\hline
\end{tabular}

Note: From “Taxonomy for the Technology Domain” by L. D. Tomei, 2003. Retrieved on June, 04, 2004 from http://www.duq.edu/\%7Etomei/taxonomy/ Reprinted with permission of the author. 
Table 4

The Technology Domain

\section{Action Verbs That Represent Intellectual}

Taxonomy Classification Activity On This Level

Access online course materials, change default system settings, link to web sites, launch

Literacy

Understanding technology

Collaboration

Sharing ideas software applications, bookmark web sites, participate in a chat session, construct a visual presentation, fill and graph a spreadsheet, populate a database, locate sites using search engines, program function keys on a keyboard, adjust mouse speed and scroll, insert clip art and images, change font and text size, cut/copy/paste, operate a printer.

Send electronic messages, post ideas to a bulletin board, word process a research synopsis, populate and subscribe to an educational listserve, electronically exchange spreadsheet data, capture and incorporate sound bytes, attach an electronic signature, participate in an online chat. 
Table 4 (continued)

The Technology Domain

Prepare an electronic spreadsheet, prepare a decision paper, find information in a CDROM encyclopedia, search online newspapers, create

Decision-Making

Solving problems

Infusion

Learning with Technology an inquiry-based science project, prepare a digital resume, create a digital Venn diagram, diagnose a simulated illness using anatomical software, develop a logarithm formula for calculating proper dosages, use brainstorming software to support a plan of action.

Take a distance education course, appraise educational software, select appropriate multimedia resources, integrate online learning environments, create web-based lesson home page, create text-based handouts and study guides, create visual-based classroom presentations, download digital maps for exploration, use the digital camera to prepare an electronic insect collection. 
Table 4 (continued)

The Technology Domain

Create an interactive workbook, fashion an interactive visual lesson, create a web-based

Integration

Teaching with Technology virtual tour, build a language arts portfolio, download maps and originate a digital atlas of the US, produce an educational software package.

Debate the impact of online chat on language development, debate the use of internet filters in schools, advocate for distance learning in the

Tech-ology

The study of technology community at large, develop a personal position concerning the impact of technology on society, argue for the ethical use of technology in medicine, predict technology's probable future roles in society, examine the uses and abuses of technology, copyright and fair use laws for using technology.

Note: From “Taxonomy for the Technology Domain” by L. D. Tomei, 2003. Retrieved on June, 04, 2004 from http://www.duq.edu/\%7Etomei/taxonomy/ Reprinted with permission of the author.

There is a close relation between Tomei's taxonomy for the technology domain and the NETS for teachers. While the NETS for teachers focus on the goals to be achieved by the teachers, Tomei's taxonomy for the technology domain list the actions that would lead to the 
achievement of the NETS for teachers' goals. Together they are powerful tools that can facilitate the implementation of technology in today's education system.

Research Findings about Characteristics of Effective and Successful Professional Development

Programs for Educators

Although professional development is considered to be one of the main factors in the improvement of education, educators still face the misfortune of participating in professional developments that lack planning, support, resources or/and an adequate structure offering to educators nothing but a meaningless and wasteful experience (Guskey, 2000). The fact is that "schools can be no better than the teachers and administrators who work in them" (Guskey, 2003, p. 40). Thus, in order to see any significant change in teachers' practice there is a need for high quality professional development efforts as part of any education improvement planning (Guskey, 2003).

There are a number of teachers and school administrators that still have a restricted view of professional development as being short term workshops conducted as special events and without prior involvement of the participants in its planning, resulting in most of the times in a disconnection between what is presented and what is actually considered a need in the classroom daily educational practices. It is important to realize that workshops, lectures, and presentations are as effective as any other approach to professional development when considering the goals for which they are designed and their sustainability throughout times. Teachers need support in the process of attempting to apply the knowledge gained in their daily classroom practice (Guskey, 2000; Holland, 2001).

According to the Office of Technology Assessment (1995), most technology professional developments have succeeded in the aim of helping teachers to master instructional technology 
tools such as word processing, database, spreadsheet, and Internet search. Nevertheless a great majority struggles in finding the best approach to promote an effective and pedagogically sound integration of instructional technology into the curriculum.

Guskey (2003) states that "the criteria for determining the effectiveness of professional development vary depending on the intended audience" (p. 46). According to Guskey (2003) "effectiveness, like beauty, is in the eye of the beholder" (p. 46).

The following list addressing the most common characteristics of successful and effective instructional technology professional development programs was resulted from an in-depth literature review on the topic (Bray, 1998; Bybee, 2001; Crawford, 2003; Feist, 2003; Garet, et. al., 2001; Knowles, Holton, \& Swanson, 1998; Gonzales, Pickett, Hupert, \& Martin, 2002; Guskey, 2000; Mckenzie, 1998; Mckenzie, 2001; National Foundation for the Improvement of Education, 2000; North Central Regional Education Laboratory, 2003; Sparks, 2002; Whitfield \& Latimer, 2003). Effective and successful professional development must:

1. Be intentional and focused on broadening teachers knowledge and pedagogical skills to promote students' learning and the integration of technology into the curriculum rather than focusing on building up skills on a specific software - when establishing the goals of any professional development one must understand that they should focus on issues related to learning and learners (Bybee, 2001; Gonzales, et. al, 2002; Guskey, 2000; Mckenzie, 1998; National Foundation for the Improvement of Education, 2000; Sparks, 2002).

a. Begin with a clear statement of purpose and goals

b. Ensure that the goals are worthwhile

c. Determine how the goals can be assessed (Guskey, 2000, p.19) 
d. Ensure that the goals are achievable (Sparks, 2002)

2. Be an ongoing process - it goes beyond a 3 or 4 days workshop, and the concept of "one shot" or short duration workshop. It usually involves a significant number of hours and the sessions are related to each other as well as to the classroom practice. It is continuous and can take a formal shape as a workshop or informal one as on site visits or the help desk. It is sustainable over time through ongoing support for participants in order for them to apply what is learned in their instruction and later modify it to better adapt it to his/her educational practice. (Crawford, 2003; Garet, et. al., 2001; Guskey, 2000; Grant, 1996; National Foundation for the Improvement of Education, 2000; Whitfield \& Latimer, 2003)

3. Be a systemic process that believes that change happens over an extended period of time and takes into account all levels of the organization. The changes that happen in a large scale are guided by a series of small steps that focus on the learning process and the learner. Thus it is sustained over time through the process of continuous incorporation of the technology into the school culture (Garet, et. al, 2001; Guskey, 2000; National Foundation for the Improvement of Education, 2000; Sparks, 2002; Office of Technology Assessment, 1995)

4. Be flexible and have a multimodal approach, offering different strategies to achieve a goal and support the different learning style of learners participating in the professional development (Crawford, 2003; Feist, 2003; Grant, 1996; Guskey, 2000; National Foundation for the Improvement of Education, 2000).

5. Be designed in line with the andragogical principles, respecting the adult learners and their learning characteristics. Adult learners build new knowledge upon connection to old 
ones and are more likely to learn when what is offered is directly linked to their perceived needs, offering them the opportunity to apply immediately the new knowledge to their current practices. (Bray, 1998; Bybee, 2001; Crawford, 2003; Feist, 2003; Garet, et. al., 2001; Knowles, Holton, \& Swanson, 1998; Mckenzie, 1998; Mckenzie, 2001; North Central Regional Education Laboratory, 2003; Sparks, 2002; Whitfield \& Latimer, 2003)

6. Have the following preconditions:

a. Adequate time to dedicate to the professional development and flexible scheduling fitting teachers' busy schedule

b. Structured in a coherent long term plan

c. Ready access to technology equipment by the participants

d. Access to on-demand, onsite technical and pedagogical assistance. Participants want help in whatever topic or program they might be having problems.

e. The choice of certain hardware or software should be based on the school's educational goals. The decisions on the purchase of any software or hardware must be guided by sound educational reasons.

f. Participants should be trained on the software and hardware they have access in their school and that they are using or planning to use with their students.

g. The learning resulted from the participation on the professional development should be of immediate application on their teaching

h. Incentives as release time or money bonus for teachers to learn and apply what is learned in their instruction

i. Adequate funding for technology as well as human resources 
j. An infrastructure and administrators that support collaboration, inquiry and innovation

k. An approach that emphasizes the development of confidence, comfort and competence in the use of technology (Bray, 1998; Feist, 2003; Garet, et. al, 2001; Goodale, Carbonaro, \& Snart, 2003; Grant, 1996; Holland, 2001; Mckenzie, 1998; National Foundation for the Improvement of Education, 2000; Office of Technology Assessment [OTA], 1995; Sparks, 2002; Schrum, 1999; U.S. Department of Education, 2000; Whitfield \& Latimer, 2003)

7. Be a collaborative process and be based on constructivist theories providing opportunities for teachers to discuss, practice, research, reflect, try things out, analyze the success or failure, revise and try the use of instructional technology in their school context again (Mouza, 2002-2003; North Central Regional Education Laboratory, 2003; OTA, 1995; Sparks, 2002)

8. Provide follow-up support and further mentoring to promote participants' integration of instructional technologies into their teaching. Professional development activities should have built in follow-up procedures (Feist, 2003; Goodale et. al, 2003; Mouza, 2002-2003; OTA, 1995)

9. Provide technical and pedagogical support to assure the efficient use of technology in the classroom by the teachers participating in the professional development. The integration of technology should reflect and directly relate to curriculum goals. First should come the emphasis on the curriculum and then on the use of technology to support it (Feist, 2003; Mouza, 2002-2003; OTA, 1995) 
10. Be designed in a way to offer significant support that will lead to the use of technology in a pedagogically sound way. Examples of good practices on the use of technology to empower teachers and students is a must to guarantee the success of professional development (Grant, 1996; Gonzales, et. al, 2002; OTA, 1995)

11. Create a community of learners from the same school subject or grade, thus having a districtwide and site based approach. Allowing educators who are undergoing the experience of technology professional development to share their experiences (Garet, et. al, 2001; Gonzales, et. al, 2002). "A thoughtful combination of large-scale and contextspecific approaches can optimize the potential benefits of each and drastically improve both the efficiency and effectiveness of professional development practices" (Guskey, 2000, p. 31).

12. Be designed with the cooperation of the participants, incorporating their needs, and allowing them to shape their own learning. It must take into account participants' knowledge level and perceptions that they have during their different developmental stage. Learners take an active and responsible role in planning, acting and learning within the context of the curriculum they have to teach (Bray, 1998; Bybee, 2001; Grant, 1996; Holland, 2001; Mckenzie, 2001; National Foundation for the Improvement of Education, 2000; Schrum, 1999; U. S. Department of Education, 2000)

13. Be coherent, thus making a connection between technology and the school curriculum as well as to national, state and local educational standards (Feist, 2003; Garet, et. al., 2001; National Foundation for the Improvement of Education, 2000) 
14. Require repeated cycles of shared professional development to support teachers to keep up with the new technologies, practices and research on the area of instructional technology (National Foundation for the Improvement of Education, 2000)

15. Have a subject matter focus. It should make a connection between theory and practice bringing to the participants issues relevant to their own instruction deepening their subject area knowledge and offering instructional strategies that could enhance students' learning. Educators learn by solving pertinent problems to the subject and grade level that they teach (Bray, 1998; Garet, et. al, 2001; National Foundation for the Improvement of Education, 2000; Sparks, 2002)

16. Recognize the teacher as a main facilitator of students' learning. It must recognize how important it is for teachers, the community, and the administrator to work together on the accomplishment of the efficient use of technology and how it might better be used to support their educational philosophy (Bybee, 2001; Feist, 2003; OTA, 1995; Sparks, 2002; U.S. Department of Education, 2000).

17. Have a continuous evaluation process. Evaluations should take place before, during and after any professional development. It should gauge the changes and the planning process (Bray, 1998; Bybee, 2001; Guskey, 2000; Mckenzie, 1998; National Foundation for the Improvement of Education, 2000)

18. Involve active learning. Technology not only requires relevant hands-on training but also the development of critical thinking on the application of the tools in which participants are going to be exposed and trained. It requires an interactive approach where learners feel as conducting their own learning experience (Bybee, 2001; Garet, et. al, 2001; Goodale, et. al, 2003; Grant, 1996; Mouza, 2002-3003; OTA, 1995) 
19. Be designed based on the latest research evidences available (Guskey, 2003).

In today's educational settings the concept of effective professional development has dramatically changed from the, "one fits all approach" to deliver information to educators, to "systematic effort to bring about change", an opportunity for educators to "discuss, think about, try out, and hone new practices in an environment that values inquiry and experimentation" (Guskey, 2000, p. 7). Furthermore, as stated by Schrum (1999) one of the most difficult challenges of technology professional developments is "to support many different models of technology use to meet the needs of different students, teachers, classroom situations, and learning goals; and to support each teacher in the complex and long term process of refining one's own beliefs and teaching practices" (para. 14). Nevertheless, professional development is essential for the effective integration of instructional technology in teaching practice (Mouza, 2002-2003).

\section{Major models of professional development}

Due to the different kinds of professional needs, different approaches are used to professional development. All have at least one common characteristic: the need to be ongoing (Salpeter, 2003). The major approaches are the following:

1. Training (Conferences, Institutes and Workshops): most of the time it consists of one or more presenters that share their ideas and practices about a subject and guide a series of group-oriented activities. It is considered to be one of the most efficient and cost effective approaches of professional development. However it lacks flexibility and opportunities for customized learning. To be truly effective these approach to professional development has to provide follow-up activities and help, giving participants enough support for the 
actual implementation of what was learned in their teaching (Grant, 1996; Guskey, 2000; National Foundation for the Improvement of Education, 2000)

2. Observation/Assessment: one can learn a lot by observing and being observed, receiving constructive feedback, and analyzing and reflecting on one's own practice. When the purpose of the observation is set, the kind of feedback that one will receive is more likely to be more relevant to the area or issue in which he/she is trying to improve. However, observation has its constraints it is limited to certain settings and might encounter problems as scheduling time for the observations to take place without overlapping teachers' class hours if one wants to avoid hiring substitutes (Garet, et. al, 2001; Grant, 1996; Guskey, 2000).

3. Involvement in a development/improvement process: a group of educators get together to discuss the improvement of a certain area in the curriculum or their instruction. Most of the time it is a very successful approach since the people involved are interested in the outcomes and have expertise in the area that is being discussed. "School-university partnerships and collaborative relationships, as well as educational cooperatives, are especially useful for these purposes" (Guskey, 2000, p. 25). This kind of partnership can promote an exchange in learning experiences and foster effective practices (Grant, 1996).

4. Study groups: the search for a solution for a determined problem by the school staff. To be successful it should be well structured, the groups should be well supported and well trained (Guskey, 2000; National Foundation for the Improvement of Education, 2000).

5. Inquiry/Action Research: Teachers study what they do in order to improve their own practice (National Foundation for the Improvement of Education, 2000). According to Calhoun (as cited in Guskey, 2000) the inquiry professional development usually 
includes five steps that overlap. "Educators are required to a) select a problem question of collective interest; b) collect, organize, and interpret information related to the problem; c) study the relevant professional literature and research ; d) determine possible actions that are likely to achieve commonly valued goals; e) take action and document results".

6. Individually guided activities: educators drive their own learning by choosing what they will learn and the activities that will best lead to their learning goals. According to Sparks and Loucks-Horsley (as cited in Guskey, 2000) this professional development include the following: (a) identification of a need of interest, (b) development of a plan to meet the need or interest, (c) learning activities, and (d) assessment of whether the learning meets the identified need or interest" (p. 27).

7. Mentoring: Based on the close relationship between human and learning, less experienced educators are paired up with more experienced ones who have the opportunity to observe, share ideas and strategies; and to have an individualized learning experience filled with challenges and support through guided and constructive feedback. However one has to keep in mind that significant time is needed to nurture the relationship between a mentor and the person being mentored. Besides the ideal mentoring matches are not always easy to find (Grant, 1996; Guskey, 2000; National Foundation for the Improvement of Education, 2000).

8. Teacher Network and Online Communities: teachers share their ideas, problems and solutions with other teachers forming a network that can communicate online or face-toface. These "anytime, anywhere" learning communities help teachers to share experiences, collaborate and determine best practices. The success of an online community can be seen when its members keep communicating with each other even 
when the main issue for which the community was created has been solved (National Foundation for the Improvement of Education, 2000; Salpeter, 2003).

9. Train the Teachers: a group of teachers are selected based on their motivation and enthusiasm of learning a certain topic. In terms of technology they are mostly energetic early adopters. They are given training and are requested to provide onsite training in what they have learned to other teachers, inspiring their colleagues in the different uses of technology in teaching. They are given time and administrative support once they return to their buildings to share their knowledge with other teachers. The pitfall of this approach is that trainers have different timing concerning achieving a comfort level with the new information they received in order to feel ready to convey what they have learned to others. Therefore time and support are essential to guarantee the success of this approach (Grant, 1996; OTA, 1995; Salpeter, 2003).

The context where the professional development is going to take place can strongly influence the characteristics that contribute to professional development's effectiveness (Guskey, 2003). Nevertheless, according to Guskey (2000) a combination of the models above is essential to bring effectiveness to any professional development and promote the expected changes.

Professional development programs are considered to be essential for any educational settings where educators' development and success are considered to be one of the institutions' main goals. "At the core of each and every successful educational improvement effort is a thoughtfully conceived, well-designed, and well-supported professional development component" (Guskey, 2000, p. 4). However "seldom is the professional development component thoroughly described or evaluated in sufficient detail to offer practical guidance for those wishing to understand the complexities of the improvement process" (Guskey, 2000, p. 5). 
Therefore, this study aims to investigate the strategies employed by successful IT professional development that promote pedagogically appropriate use of ITs as part of teachers' teaching practice. 


\section{CHAPTER III: METHOD AND PROCEDURE}

The purpose of this study was to determine a set of common strategies employed by sustainable instructional technology professional development programs that are found to successfully promote educators' high-level use of technology in their teaching practice.

\section{Research Questions}

The research questions guiding this study were:

1. What do successful instructional technology professional development programs recognize as indicators of high-level use of technology?

2. Which instructional technology professional development strategies successfully promote high-level use of instructional technology in participants' teaching practice?

\section{Research Design}

This research used a mixed-method approach. The main source of data collection was a self-administrated, self-reporting, cross-sectional (one fixed point in time) electronic survey. The electronic survey had close-ended questions scored using a 5-point Likert scale. The quantitative data collected from this section were analyzed using central tendency measures. For each survey's close-ended questions there was a corresponding open-ended question. The open-ended questions were analyzed using qualitative content analysis.

An overview of this study's methodology is provided in Table 5: 
Table 5

Methodology Overview

\begin{tabular}{|c|c|c|c|}
\hline Research Questions & Data Source & Data analyses & Expected outcomes \\
\hline 1. What do successful instructional & Self-explanatory, self- & Descriptive analyses & List of the indicators of high- \\
\hline technology professional & administrated cross-sectional & & level use of technology most \\
\hline development programs recognize & Pedagogical Use of & & used by the participants \\
\hline as indicators of high-level use of & Instructional Technology in & & \\
\hline \multirow[t]{2}{*}{ technology? } & Teaching Questionnaire & & \\
\hline & close-ended questions. & & \\
\hline 2. Which instructional technology & Pedagogical Use of & Content Analysis & Matrix of the most common \\
\hline professional development & Instructional Technology in & & strategies used to achieve the \\
\hline strategies successfully promote & Teaching Questionnaire & & identified indicator of high-level \\
\hline high-level use of instructional & open-ended questions. & & use of technology. \\
\hline \multicolumn{4}{|l|}{ technology in participants' } \\
\hline teaching practice? & & & \\
\hline
\end{tabular}


The participants of this study were purposefully sampled; they were selected as "informationrich cases whose study will illuminate the questions under study" (Patton, 2002, p. 46). The first research question was answered using data from the survey's close-ended responses and the second research question was answered using data generated from the survey's open-ended responses. This study determined the indicators of high-level use of technology as identified by the participants, and the most common strategies used to achieve them. The following steps were taken in order to conduct this study: (a) identification of participants, (b) questionnaire development, (c) administration of questionnaire, and (d) data collection and analyses.

\section{Identification of Participants}

As recognized by many researchers (Garet et al., 2001; Guskey, 2000; National Foundation for the Improvement of Education, 2000; Office of Technology Assessment, 1995; Sparks, 2002) professional development for teachers is essential in improving the quality of education. Following this perspective, the current study focused on the professional development for teachers.

The pool of potential participants was purposefully selected, and was comprised of 179 directors or their designees of the PT3 1999 and 2000 implementation grant awardees from across the United States and its territories. PT3 awarded three different kinds of grants: "capacity-building grants to lay the initial groundwork for a teacher preparation reform strategy, implementation grants to encourage systemic reform of teacher preparation programs, and catalyst grants to stimulate largescale, innovative improvements for preparing technology-proficient teachers" (U.S. Department of Education, 2000, para. 3). These grants were awarded through a careful screening of participants who offered a well-detailed and high-quality proposal explaining how they would prepare prospective faculty to effectively integrate technology into their future teaching practice. 
The implementation grants awarded in 1999 and 2000 were required to provide strong evidence that they would accomplish the following: (a) establish clear and feasible teaching and learning goals, (b) develop a well structured plan to help k-12 and higher education faculty to incorporate technology into their teaching and thus improve prospective teachers' learning experience, (c) prepare a careful and detailed plan concerning the budget necessary to support the learning experiences, (d) design an ongoing evaluation plan, (e) participate in regional meetings and a national conference, and (f) promote the formation of a community of learners (Preparing Tomorrow's Teacher to Use Technology [PT3], 1998). The criteria described above reflect the characteristics of successful professional programs found through the conducting a careful and indepth literature review on this topic by the researcher.

This study focused specifically on implementation grants awarded in 1999 and 2000 because (a) they have already been identified by PT3 as successful programs, (b) their evaluation process is over, and (c) they had time to reflect upon their program and perfecting it.

\section{Questionnaire Development}

A questionnaire was developed to answer this study's research questions. The questionnaire was comprised of both close-ended and open-ended questions. Data from the close-ended questions were used to answer Research Question 1 and the data from the open-ended questions were used to answer Research Question 2. The close-ended and open-ended questions were interrelated. The questionnaire was administered online. Measures, described further on this study, were taken to guarantee the confidentiality and anonymity of the responses. In order to develop the instrument used for data collection the researcher took the following steps:

1. Identification of the high-level use of technology indicators presented in the literature. 
2. Establishment of the connection between NETS for teachers and the high-level use of technology indicators identified in the literature.

3. Identification of reliable and valid surveys related to the assessment of high-level use of instructional technology in teaching practice.

4. Identification of the questions in the surveys that dealt with high-level use of instructional technology.

5. Cross-referencing of the selected questions with the high-level use of technology indicators found in the literature.

6. Elimination of overlapping questions.

7. Testing for content validity.

8. Posting the questionnaire on password protected university server.

9. Tested questionnaire design and assured the efficiency of the method of delivery.

10. Revision and modification of the survey.

11. Contact of participants.

12. Completion of survey by participants.

High-Level Use of Technology and NETS for Teachers

An in-depth literature review was conducted to identify the indicators of high-level use of instructional technology in teaching practice. The rationale for using instruments related to NETS for teachers (International Society for Technology Educational [ISTE], 2000) for development of this study's data collection instrument is: (a) the accreditation of International Society for Technology Educational (ISTE) by the National Council for the Accreditation of Teacher Education (NCATE) and the recognition of the importance of NETS for teacher by NCATE (ISTE, 2003b); (b) "at the state level, 48 of the 51 states have adopted, adapted, aligned with, or otherwise referenced at least 
one set of standards in their state technology plans, certification, licensure, curriculum plans, assessment plans, or other official state documents" (ISTE, 2003a, para. 1); (c) that well-known international organizations such as the United Nations Educational, Scientific and Cultural Organization (UNESCO) are adopting NETS for teachers and administrators and translating them into eight languages to be distributed among the 185 nations that are members of UNESCO (Roblyer, 2003), and (d) the partnership between the Department of Education PT3 Programs and ISTE.

\section{Identification of Existing Surveys}

In order to have a fair sample of the domain an in-depth review of literature was conducted to identify surveys that addressed high-level use of technology. From this review, the researcher evaluated a set of surveys and identified possible questions that were adapted for the purpose of this study. Among the surveys that were evaluated, the ones that most closely addressed NETS for teachers and had questions that dealt with the high-level use of technology were the following:

1. The National Educational Standards for Teachers Profiles created by ISTE for assessing the level of compliance of teachers with the NETS standards (International Society for Technology in Education [ISTE], 2003).

2. The Professional Competency Continuum (PCC) Assessment Tool survey commissioned by the Milken Exchange on Education Technology. This survey was designed to allow educators to assess their "professional competency in the use of education technology" and indicate the areas in which educators need support for effective integration of technology in learning (Coughlin \& Lemke, 1999, p. 10). The statements that were used in the construction of this study's instrument dealt with 
higher use of technology and can be found under the transformation category of the PCC tool.

3. The Levels of Technology Implementation Questionnaire (LoTi) was designed by Moersch (1996-1997) with the objective of providing "a fair approximation of teacher behaviors related to technology implementation" (p. 41). Thus, assisting "school districts in restructuring their staff's curricula to include concept/ process-based instruction, authentic, uses of technology, and qualitative assessment" (p. 41).

None of the surveys above dealt solely with the issue of high-level use of technology. Therefore it was necessary to carefully select the questions and to adapt them in order to address this study's needs.

\section{Questionnaire Design}

The design of the questionnaire utilized both close-ended and open-ended questions. The questionnaire's close-ended questions were adapted from (a) the National Educational Standards for Teachers Profiles created by ISTE, (b) Level of Technology Implementation Questionnaire (LoTi) Preservice Teacher, Higher-Education Teacher, and Inservice Teacher, version 4.0, created by Moersh, and (c) the Professional Competency Continuum (PCC) Assessment Tool survey commissioned by the Milken Exchange on Education Technology. The PCC Assessment tool assesses different areas of technology integration. For the purpose of this survey, the questions adapted from the PCC Assessment tools were the ones that dealt with the assessment of technology integration in relation to curriculum, learning and assessment, and professional practice.

The survey questions identified for inclusion were those that best matched the high-level use of technology indicators described in this study's literature review (see pp. 26-28). The list of indicators was used to evaluate each of the selected instruments' questions. Selected questions from 
the different instruments were compared among themselves for similarities. Overlapping questions, those that were stated differently but meant the same, were eliminated (see Appendix A).

The questions identified for inclusion were classified under five categories created based on the review of literature on high-level use of technology indicators (see pp. 26-28 of this document). The classification process was done as follows: (a) a panel of three experts reviewed the categories for appropriateness of used terminology, (b) each of the three experts placed the questionnaire's question under the category he/she found to be most appropriate, (c) the researcher and the panel of experts met to reach a consensus regarding the questionnaire's questions and the categories in which they belong, (d) a consensus was achieved when three of the four people meeting agreed regarding the category in which the questionnaire's question belonged. Following the consensus meeting the 13 categories that were first conceptualized by the researcher, were collapsed to 5 categories (see Table 6; Table 7).

Table 6

High-Level Use of Technology Categories and Questionnaire's Items (Before Consensus Meeting)

\section{Categories of High-Level Use of Technology}

Questionnaire's Items

\begin{tabular}{lll}
\hline 1. & Learner-centered - Learning to learn instruction & 6 \\
\hline 2. & Creation of community of learners & $13,17,21,26$ \\
\hline 3. & Creation of community of practice & 10 \\
\hline 4. & Learner autonomy & 14 \\
\hline 5. & Appropriate use of Instructional Technology & $1,22,23,24,27$ \\
\hline 6. & Development of critical thinking & 2 \\
\hline 7. & Development of cross-cultural understanding & 15 \\
\hline 8. & Enhancement of communication skills & 12,16 \\
\hline 9. & Enhancement of problem solving skills & $3,18,25$ \\
\hline 10. Implementation of project-based learning & 19,20 \\
\hline 11. Multiple learning approach & 8,11 \\
\hline 12. The use of ITs aligned to curriculum goals, and national and state standards & $4,5,7$ \\
\hline 13. Multiple measures for evaluating students & 9 \\
\hline
\end{tabular}


Table 7

High-Level Use of Technology Categories and Questionnaire's Items (After Consensus Meeting)

\section{Categories of High-Level Use of Technology Questionnaire's Items}

1. Learner-centered: (merged: 1 Learner-centered, 4 Learner $\quad 6,8,11,14$, autonomy, 11 Multiple learning approach)

2. Community of learners: (merged: 2 Creation of community of $12,13,15,16,17,21,26$ learners, 8 Enhancement of communication skills, 7 Development of cross-cultural understanding)

3. High-order thinking skills: (merged: 6 Development of critical 2, 3, 18, 19, 20, 25 thinking, 9 Enhancement of problem solving skills, 10 Implementation of project-based learning)

4. Appropriate use of Instructional Technology: (merged: 3 $1,4,5,7,10,22,23,24,27$ Creation of community of practice, 5 Appropriate use of Instructional Technology, 12 The use of ITs aligned to curriculum goals, and national and state standards)

5. Assessment: (13 Multiple measures for evaluating students) 9

Note: Detailed explanation of the above categories is given on pp. 26-28 of this document. Refer to Appendix A for individual questionnaire items.

The following criteria were used when determining the panel of experts: (a) deep understanding and exposure to the area of research, (b) use of instructional technology in their own practice for communications, decision-making, instruction, integration and acculturation as described by Tomei (2002), (c) influence others, such as, pre-service teachers, in the high-level use of technology in the classroom. 
As stated earlier the questionnaire had two interrelated sections. For each close-ended question there was an open-ended that requested a description of the strategies used to address the close-ended questions. Responses to the close-ended questions took the form of a continuous ordinal rating scale. Following Fowler's (1995) advice, the questionnaire had open-ended questions because "the list of possible answers is not known or is very long" (p. 59).

\section{Instrument Content Validity}

According to Hittleman and Simon (2002) in order to establish the content validity of the questionnaire the instrument creator has to "demonstrate that the specific items or questions represent an accurate sampling of specific bodies of knowledge. Creators of instruments establish content validity by submitting the instruments' items to a group of authorities in the content areas. It is their expert opinions that determine whether the instruments have content validity" (p. 112).

Therefore, the researcher asked a panel of three "specialists in the area to review the instrument and agree that 'yes, these are the appropriate items to get what is desired'"(Cox, 1996, p. 35). The same experts that guided categorizing the questionnaire's questions participated in establishing the content validity of the questionnaire. The following criteria were used when determining the panel of experts: (a) deep understanding and exposure to the area of research, (b) use of instructional technology in their own practice for communications, decision-making, instruction, integration and acculturation as described by Tomei (2002), and (c) in a position to influence others, such as, pre-service teachers, in the high-level use of technology in the classroom.

The researcher met with the three experts and explained the purpose and objective of the study, and reviewed the content validity process to be carried out. A folder including the following content was given to each of the experts: (a) a copy of the original instruments used to construct the questionnaire, (b) comparison table of questionnaire's items and instruments used to create them (see 
Appendix A), (c) assessment of questionnaire's content validity tool (see Table 8), and (d) explanation of categories (see pp. 20-23).

The experts were asked to categorize the questions and to evaluate each question according to the criteria suggested by Yaghmaie (2003). Each item was judged for its content domain with the criteria of relevance (R), clarity (C), simplicity (S), and ambiguity (A). Experts rated the questions using a 4-point scale where the value of 1 was attributed to Strongly Disagree, 2 to Disagree, 3 to Agree, and 5 to Strongly Agree (see Table 8). For the criteria of ambiguity a reversed scale was used where 4 was attributed to Strongly Disagree, 3 to Disagree, 2 to Agree, and 1 to Strongly Agree.

The following definitions were used by the experts when assessing the questionnaire items: (a) relevance: relation to the matter at hand, (b) clarity: free of confusion, the comprehensibility of clear expression, (c) simplicity: directness of expression, uncomplicated, readily understood (d) ambiguity: capable of being understood in two or more possible senses or ways (Merriam-Webster, 1995).

The experts were given one week to analyze the questions, rate them, and comment on the categorization process. Analysis of the results of the content validity process was done using the Content Validity Index (CVI), developed by Waltz and Bausell (1983), which is the "proportion of items given a rating of 3 or 4 by the raters involved" (p. 71). As suggested by Yaghmaie (2003) only those items receiving CVI 0.75 or higher were considered suitable for the study without questioning (see Table 8).

$\mathrm{CVI}=\quad$ number of items given a rating of 3 or 4 by raters

Total number of items for which the question is being evaluated

A second meeting was arranged to present the results and discuss the questionnaire until an agreement was met concerning each item that would be included and those that would be excluded from the questionnaire. A consensus was reached when two of the three experts agreed. 
Of the 29 items 12 (questions 5, 10, 12, 14, 16, 17, 18, 19, 23, 25, 27, and 29) had a CVI below 0.75 . However, only two (questions 12 and 23) of the twelve were eliminated. The other 10 were considered by the experts worth keeping with modifications, or clarifications. Even when the CVI was above 0.75 the experts still went over the questions together to check for appropriate language and a broader consensus, as a result slight modifications were made on the questions under the supervision and agreement of the panel of experts (see Table 8). 
Table 8

Results of Assessment of Questionnaire's Content Validity

\begin{tabular}{|c|c|c|c|c|c|c|c|c|c|c|c|c|c|}
\hline \multirow{2}{*}{$\begin{array}{c}\text { Questionnaire Items } \\
\text { Our professional development prepared } \\
\text { participants to: }\end{array}$} & \multicolumn{4}{|c|}{ Expert 1} & \multicolumn{4}{|c|}{ Expert 2} & \multicolumn{4}{|c|}{ Expert 3} & \multirow{2}{*}{$\begin{array}{l}\text { Content Validity } \\
\text { Index (n. of } 3 \text { and } \\
4 \text { divided by 12) }\end{array}$} \\
\hline & $\mathbf{R}^{*}$ & $\mathbf{C}^{*}$ & $\mathbf{S}^{*}$ & $\mathbf{A}^{*}$ & $\mathbf{R}^{*}$ & $\mathrm{C}^{*}$ & $\mathbf{S}^{*}$ & $\mathbf{A}^{*}$ & $\mathbf{R}^{*}$ & $\mathbf{C}^{*}$ & $\mathbf{S}^{*}$ & $\mathbf{A}^{*}$ & \\
\hline $\begin{array}{l}\text { 1. differentiate between appropriate and } \\
\text { inappropriate uses of technology for } \\
\text { students' grade level and content area. }\end{array}$ & 4 & 4 & 4 & 4 & 4 & 3 & 3 & 4 & 4 & 3 & 4 & 4 & $12 / 12=1$ \\
\hline $\begin{array}{l}\text { 2. design and implement learning activities } \\
\text { that integrate technology to support and } \\
\text { expand students' critical thinking }\end{array}$ & 4 & 4 & 4 & 4 & 4 & 4 & 4 & 4 & 4 & 4 & 4 & 4 & $12 / 12=1$ \\
\hline $\begin{array}{l}\text { 3. design and implement learning activities } \\
\text { that integrate technology to support and } \\
\text { expand students' } \\
\text { skills }\end{array}$ & 4 & 3 & 3 & 4 & 3 & 3 & 3 & 3 & 4 & 4 & 4 & 4 & $12 / 12=1$ \\
\hline $\begin{array}{l}\text { 4. design and implement learner-centered } \\
\text { lessons that are based on the current best } \\
\text { practices for integrating the learning of } \\
\text { subject matter and student technology } \\
\text { standards }\end{array}$ & 4 & 4 & 4 & 4 & 3 & 3 & 2 & 2 & 4 & 4 & 3 & 4 & $10 / 12=\mathbf{0 . 8 3}$ \\
\hline $\begin{array}{l}\text { 5. assess learner-centered lessons that are } \\
\text { based on the current best practices for } \\
\text { integrating the learning of subject matter } \\
\text { and student technology standards }\end{array}$ & 4 & 4 & 4 & 4 & 2 & 2 & 2 & 2 & 4 & 4 & 4 & 4 & $8 / 12=\mathbf{0 . 6 6}$ \\
\hline $\begin{array}{l}\text { 6. design and implement student-centered, } \\
\text { instructional materials that take advantage } \\
\text { of computers to engage students in their } \\
\text { own learning }\end{array}$ & 4 & 4 & 4 & 4 & 4 & 4 & 4 & 4 & 4 & 3 & 3 & 3 & $12 / 12=1$ \\
\hline $\begin{array}{l}\text { 7. design and teach technology-enriched } \\
\text { learning activities that connect content, state } \\
\text { and national standards with student } \\
\text { technology standards }\end{array}$ & 4 & 4 & 4 & 4 & 4 & 4 & 4 & 4 & 4 & 4 & 4 & 4 & $12 / 12=1$ \\
\hline
\end{tabular}

R: relevance; C: clarity; S: simplicity; A: ambiguity

Shaded Area: Item eliminated 
Table 8 (continued)

Results of Assessment of Questionnaire's Content Validity

\begin{tabular}{|c|c|c|c|c|c|c|c|c|c|c|c|c|c|c|}
\hline \multirow{2}{*}{\multicolumn{2}{|c|}{$\begin{array}{c}\text { Questionnaire Items } \\
\text { Our professional development prepared } \\
\text { participants to: }\end{array}$}} & \multicolumn{4}{|c|}{ Expert 1} & \multicolumn{4}{|c|}{ Expert 2} & \multicolumn{4}{|c|}{ Expert 3} & \multirow{2}{*}{$\begin{array}{l}\text { Content Validity } \\
\text { Index (n. of } 3 \text { and } 4 \\
\quad \text { divided by 12) }\end{array}$} \\
\hline & & $\mathbf{R}^{*}$ & $\mathrm{C}^{*}$ & $\mathrm{~S}^{*}$ & $\mathrm{~A}^{*}$ & $\mathbf{R}^{*}$ & $\mathrm{C}^{*}$ & $\mathbf{S}^{*}$ & $\mathbf{A}^{*}$ & $\mathbf{R}^{*}$ & $\mathrm{C}^{*}$ & $\mathrm{~S}^{*}$ & $\mathbf{A}^{*}$ & \\
\hline 8. & $\begin{array}{l}\text { design and teach technology-enriched } \\
\text { learning activities that meet the } \\
\text { individual diverse- needs of students }\end{array}$ & 4 & 4 & 4 & 4 & 3 & 3 & 3 & 2 & 4 & 4 & 4 & 4 & $11 / 12=\mathbf{0 . 9 2}$ \\
\hline & $\begin{array}{l}\text { design an evaluation plan that applies } \\
\text { multiple measures for evaluating } \\
\text { technology-based students' products }\end{array}$ & 4 & 4 & 4 & 4 & 4 & 4 & 4 & 4 & 4 & 4 & 4 & 4 & $12 / 12=1$ \\
\hline 10. & $\begin{array}{l}\text { participate in online professional } \\
\text { collaborations with peers and experts (kept } \\
\text { without modification- consensus of } \\
\text { experts) }\end{array}$ & 4 & 4 & 4 & 4 & $?$ & $?$ & $?$ & $?$ & 4 & 4 & 4 & 4 & $8 / 12=\mathbf{0 . 6 6}$ \\
\hline & $\begin{array}{l}\text { design and facilitate learning experiences } \\
\text { that use assistive technologies to meet the } \\
\text { special physical needs of students }\end{array}$ & 4 & 4 & 4 & 4 & 4 & 3 & $?$ & 2 & 4 & 4 & 4 & 4 & $10 / 12=\mathbf{0 . 8 3}$ \\
\hline & $\begin{array}{l}\text { design, manage, and facilitate learning } \\
\text { experiences that affirm diversity } \\
\text { (redundant } 12 \text { and } 16-12 \text { was eliminated) }\end{array}$ & 4 & 4 & 4 & 3 & $?$ & $?$ & $?$ & $?$ & 4 & 4 & 4 & 4 & $8 / 12=\mathbf{0 . 6 6}$ \\
\hline 13. & $\begin{array}{l}\text { guide collaborative learning activities in } \\
\text { which students use technology resources to } \\
\text { solve authentic problems in the subject } \\
\text { area (s) }\end{array}$ & 4 & 4 & 4 & 3 & 3 & $?$ & $?$ & $?$ & 4 & 4 & 4 & 4 & $9 / 12=\mathbf{0 . 7 5}$ \\
\hline 14. & $\begin{array}{l}\text { arrange equitable access to appropriate } \\
\text { technology resources that enable students } \\
\text { to engage successfully in learning activities } \\
\text { across subject/content areas and grade } \\
\text { levels (kept without modification- } \\
\text { consensus of experts) }\end{array}$ & 4 & 4 & 4 & 4 & $?$ & $?$ & $?$ & $?$ & 4 & 3 & 3 & 4 & $8 / 12=\mathbf{0 . 6 6}$ \\
\hline
\end{tabular}

${ }^{*}$ R: relevance; C: clarity; S: simplicity; A: ambiguity

Shaded Area: Item eliminated. 
Table 8 (continued)

Results of Assessment of Questionnaire's Content Validity

\begin{tabular}{|c|c|c|c|c|c|c|c|c|c|c|c|c|c|}
\hline \multirow{2}{*}{$\begin{array}{l}\text { Questionnaire Items } \\
\text { Our professional development prepared participants to: }\end{array}$} & \multicolumn{4}{|c|}{ Expert 1} & \multicolumn{4}{|c|}{ Expert 2} & \multicolumn{4}{|c|}{ Expert 3} & \multirow{2}{*}{$\begin{array}{l}\text { Content Validity } \\
\text { Index (n. of } 3 \text { and } \\
4 \text { divided by 12) }\end{array}$} \\
\hline & $\mathbf{R}^{*}$ & $\mathrm{C}^{*}$ & $\mathrm{~S}^{*}$ & $\mathbf{A}^{*}$ & $\mathbf{R}^{*}$ & $\mathrm{C}^{*}$ & $\mathbf{S}^{*}$ & $A^{*}$ & $\mathbf{R}^{*}$ & $\mathrm{C}^{*}$ & $\mathbf{S}^{*}$ & $\mathrm{~A}^{*}$ & \\
\hline $\begin{array}{l}\text { 15. plan and implement technology-based learning } \\
\text { activities that promote student engagement in analysis, } \\
\text { synthesis, interpretation, and creation of original } \\
\text { products }\end{array}$ & 4 & 4 & 4 & 4 & 4 & 4 & 4 & 4 & 4 & 4 & 4 & 4 & $12 / 12=1$ \\
\hline $\begin{array}{l}\text { 16. facilitate students' use of technology that addresses } \\
\text { their social needs and cultural identity (kept without } \\
\text { modification- consensus of experts) }\end{array}$ & 4 & 4 & 4 & 4 & $?$ & $?$ & $?$ & $?$ & 4 & 4 & 4 & 4 & $8 / 12=\mathbf{0 . 6 6}$ \\
\hline $\begin{array}{l}\text { 17. facilitate students' use of technology that promotes } \\
\text { their interaction with the global community (kept } \\
\text { without modification- consensus of experts) }\end{array}$ & 4 & 4 & 4 & 4 & $?$ & $?$ & $?$ & $?$ & 4 & 4 & 4 & 4 & $8 / 12=\mathbf{0 . 6 6}$ \\
\hline $\begin{array}{l}\text { 18. structure a learning environment where student } \\
\text { collaboration is the }{ }^{\text {common practice }} \text { norm when using } \\
\text { technology }\end{array}$ & 4 & 4 & 4 & 4 & 2 & $?$ & $?$ & $?$ & 4 & 4 & 4 & 4 & $8 / 12=\mathbf{0 . 6 6}$ \\
\hline $\begin{array}{l}\text { 19. use students' interests, experiences and desire to solve } \\
\text { atthentic and relevant problems when planning a } \\
\text { variety of computer-related activities in their classroom }\end{array}$ & 4 & 4 & 3 & 4 & 2 & 1 & 1 & 1 & 4 & 4 & 4 & 4 & $8 / 12=\mathbf{0 . 6 6}$ \\
\hline $\begin{array}{l}\text { 20. implement project-based learning in a elassreom } \\
\text { situation that emphasizes critical content and higher- } \\
\text { order thinking skills (e.g., analysis, synthesis, } \\
\text { evaluation) using the available computers }\end{array}$ & 4 & 4 & 4 & 4 & 3 & 4 & 3 & 4 & 4 & 4 & 4 & 4 & $12 / 12=1$ \\
\hline $\begin{array}{l}\text { 21. design and implement web-based projects that } \\
\text { emphasize complex thinking skill strategies such as } \\
\text { problem-solving, scientific inquiry, or decision-making }\end{array}$ & 4 & 4 & 4 & 4 & 3 & 4 & 3 & 3 & 4 & 4 & 4 & 4 & $12 / 12=1$ \\
\hline $\begin{array}{l}\text { 22. Guide students' use of the Internet for collaboration } \\
\text { with others }\end{array}$ & 4 & 4 & 4 & 4 & 4 & 4 & 4 & 4 & 4 & 4 & 4 & 4 & $12 / 12=1$ \\
\hline $\begin{array}{l}\text { 23. design projects in which students use the elassroem } \\
\text { computer(s) for research purpose that require them to } \\
\text { investigate an issue/problem, think creatively, take a } \\
\text { position, make decisions, and/or seek out a } \\
\text { solution(redundant } 23 \text { and } 20-23 \text { was eliminated) }\end{array}$ & 4 & 4 & 4 & 4 & $?$ & $?$ & $?$ & $?$ & 4 & 3 & 3 & 3 & $8 / 12=\mathbf{0 . 6 6}$ \\
\hline
\end{tabular}

R: relevance; C: clarity; S. simplicity; A: ambiguity

Shaded Area: Item eliminated 
Table 8 (continued)

Results of Assessment of Questionnaire's Content Validity

\begin{tabular}{|c|c|c|c|c|c|c|c|c|c|c|c|c|c|c|}
\hline \multirow{2}{*}{\multicolumn{2}{|c|}{$\begin{array}{c}\text { Questionnaire Items } \\
\text { Our professional development prepared } \\
\text { participants to: }\end{array}$}} & \multicolumn{4}{|c|}{ Expert 1} & \multicolumn{4}{|c|}{ Expert 2} & \multicolumn{4}{|c|}{ Expert 3} & \multirow{2}{*}{$\begin{array}{l}\text { Content Validity } \\
\text { Index (n. of } 3 \text { and } 4 \\
\text { divided by 12) }\end{array}$} \\
\hline & & $\mathbf{R}^{*}$ & $\mathrm{C}^{*}$ & $\mathbf{S}^{*}$ & $\mathbf{A}^{*}$ & $\mathbf{R}^{*}$ & $\mathbf{C}^{*}$ & $\mathbf{S}^{*}$ & $\mathbf{A}^{*}$ & $\mathbf{R}^{*}$ & $\mathbf{C}^{*}$ & $\mathbf{S}^{*}$ & $A^{*}$ & \\
\hline 24. & $\begin{array}{l}\text { use content-specific tools (e.g., software, } \\
\text { simulation, web tools) to support learning. }\end{array}$ & 4 & 4 & 4 & 4 & 4 & 4 & 4 & 4 & 4 & 4 & 4 & 4 & $12 / 12=1$ \\
\hline & $\begin{array}{l}\text { use technology resources to facilitate } \\
\text { knowledge construction. (kept without } \\
\text { modification- consensus of experts) }\end{array}$ & 4 & 4 & 4 & 4 & $?$ & 1 & 1 & 1 & 4 & 4 & 4 & 4 & $8 / 12=\mathbf{0 . 6 6}$ \\
\hline 26. & $\begin{array}{l}\text { apply technology tools and resources to } \\
\text { collect, analyze, and interpret data and } \\
\text { report results to parents and students }\end{array}$ & 4 & 4 & 4 & 3 & 3 & 3 & 3 & 4 & 4 & 4 & 4 & 4 & $12 / 12=1$ \\
\hline 27. & $\begin{array}{l}\text { take into consideration the process of } \\
\text { transferring transfer what students' have } \\
\text { learned in the classroom to real world } \\
\text { situation (e.g., student-generated recycling } \\
\text { program, student-generated business) when } \\
\text { planning the use of technology in the } \\
\text { classroom (e.g., student-generated } \\
\text { recycling program, student-generated } \\
\text { business) }\end{array}$ & 4 & 4 & 4 & 4 & 1 & 1 & 1 & 1 & 4 & 4 & 4 & 4 & $8 / 12=\mathbf{0 . 6 6}$ \\
\hline 28. & $\begin{array}{l}\text { design online collaborative projects with } \\
\text { other entities (e.g., schools, businesses, } \\
\text { organizations) to find solutions, make } \\
\text { decisions, or seek a resolution to an issue } \\
\text { of importance to the students. }\end{array}$ & 4 & 4 & 4 & 4 & 4 & 4 & 4 & 4 & 4 & 4 & 4 & 4 & $12 / 12=1$ \\
\hline 29. & $\begin{array}{l}\text { use technology in instruction to provide } \\
\text { students with increased levels of interactivity } \\
\text { that are much higher than those that } \\
\text { previously existed in the classroom. }\end{array}$ & 4 & 4 & 4 & 3 & $?$ & 1 & $?$ & 1 & 4 & 3 & 3 & 3 & $8 / 12=\mathbf{0 . 6 6}$ \\
\hline
\end{tabular}

R: relevance; C: clarity; S: simplicity; A: ambiguity

Shaded Area: Item eliminated

Note: Adapted from "Content validity and its estimation" by F. Yaghmaie. Retrieved on March, 09, 2004 from http://www.sbmu.ac.ir/Journal/MedEdu/jme7no1/Content $\% 20$ validity $\% 20$ and $\% 20$ its $\% 20$ estimation.htm 


\section{Posting on Password Protected University Server and Questionnaire Revisions}

After the establishment of the questionnaire's content validity, the questionnaire was posted to a secure password protected university server. Electronic survey was chosen as the means of data collection for the following reasons: (a) participants have access to the required technology, (b) participants feel comfortable using the technology, (c) rapid response time, and (d) it is less expensive than mail surveys (Shannon \& Bradshaw, 2002).

The online survey had close-ended questions in the form of radio buttons from which the participants chose their response. It also had open-ended questions in the form of text box where participants typed their answers. The questions were shown all at once and for each close-ended question there was a corresponding open-ended question. Participants could complete the survey at their own pace; so long as they did not exit the program. They would not be timed out, but if they exited the questionnaire's screen they would lose the data. After completing the questionnaire, participants had to click on the submit button in order to submit their final answers. An automatic e-mail message was sent to the researcher every time a participant completed the questionnaire and hit the submit button.

To test the questionnaire design and assure the efficiency of the method of delivery a trial session was conducted. The trial session consisted of having three Technology Education doctoral students fill out the online questionnaire and e-mail the researcher their suggestions concerning the ease of completing the questionnaire, and layout. Revisions were made to the online questionnaire based on the doctoral students' suggestions and on the results of the trial session. 


\section{Data Collection}

According to Fink and Koseccoff (1985) a survey is used to "help set policy and formulate rules, provide data on the merits of services and programs, or offer new insights into thoughts and behavior" (p. 20). Surveys are "systems for collecting information to describe, compare and predict attitudes, opinion, values, knowledge and behavior" (Fink, 1995c, p. 21). Therefore, due to the focus of this study this researcher decided to use survey as the major method of collecting data.

The instrument used in this study was a self-administrated cross-sectional (one point in time) online questionnaire (see Appendix B) that was available for completion to all 179 potential participants (Fink \& Kosecoff, 1985). The questionnaire was available online for 2 weeks during the 2004-summer semester to 179 directors or their designees of 1999 and 2000 PT3 implementation grants. The researcher posted the survey online using a password protected university server as the main means of survey distribution and data collection. The crosssectional (one point in time) design was chosen as the best way to portray one's opinion at a particular time (Fink, 1995c).

The instrument, as well as an explanation of the research, was submitted to the Institutional Review Board for its approval. To assure participants' privacy and confidentiality the following was done: (a) an e-mail was sent to all 179 potential participants requesting their participation on the study with "a fair explanation of the procedures to be followed and their

purposes, (b) a description of any risk and benefits, (c) an offer to answer any inquiries, (d) and instruction that the person is free to withdraw the consent and to discontinue participation without prejudice" (p. 51). Refer to Appendix C to see the e-mail sent to participants, and Appendix D for the Institutional Review Board approval to conduct this research. 
The e-mail was sent to each participant individually, and it also contained instructions regarding how to access the online questionnaire including each participant's username and password. They were asked to indicate a proxy who could answer in their name and complete the survey in case they were willing to participate but could not, for some reason, complete the survey. Participants were encouraged to complete the survey within the period of a week (see Appendix C). Data collection was over in a two-week period. After the second week, the data collection was considered completed.

A thank-you card and a request to answer the survey were mailed on the first week of data collection together with a thank-you magnet, as a follow-up and an incentive for participating in the study (see Appendix E). At the end of the first week of data collection, an email was sent for those who had not completed the survey, asking for their participation and giving them one more week to complete the survey (Appendix F). A final reminder e-mail was sent three days before the day assigned as the final day of data collection, encouraging participants to complete the questionnaire (see Appendix G). A Thank-you e-mail was sent to each of the participants who completed the survey (See Appendix H). This procedure was used to attempt to increase response rate (Cox, 1996; Patten, 2001).

\section{Data Analysis}

This study used a parallel mixed analyses method in which the open-ended and closeended responses were analyzed separately and then "the findings are integrated after both sets of analyses have been undertaken" (Onwuegbuzie \& Teddlie, 2003, p. 366). The close-ended questions were analyzed using a 5-point Likert scale where the value of 1 was attributed to Strongly Disagree, 2 to Disagree, 3 to Not Applied in my Professional Development, 4 to Agree, and 5 to Strongly Agree. As suggested by Patten (2001), it was stated in the directions on the 
instrument that the participants might choose the option that closest corresponds to their opinion. The percentage of the responses was calculated as well as the median (Patten, 2001). The median score was used because "Since the median always falls in the middle, it is used when you want to describe 'typical' performance” (Fink \& Kosecoff, 1985, p. 79).

A list of the high-level use of technology indicators identified by the participants was generated from the questionnaire items that had a median of 3.5 or higher, which represents more than $50 \%$ of the respondents answering Agree or Strongly Agree to a question. The other items in the questionnaire that did not score a median of 3.5 or higher were disregarded. In order to capture all possible strategies all open-ended responses were analyzed.

Content analysis was the approach used to analyze the open-ended questions. The openended data were coded and categorized. According to Miles and Huberman (1994), "codes are tags or labels for assigning units of meaning to the descriptive or inferential information compiled during a study" (p. 56). Categories were created interactively, at different phases of the mixed methods research process, a priori and a posteriori of the data collection (Onwuegbuzie \& Teddlie, 2003). In this study the data were placed under the five pre-established categories that were created based on the related literature review on the topic, and reviewed by a panel of experts who agreed on them (see pp. 20-23 of this document).

Codes were generated by reading the first seven survey responses ( $10 \%$ of the total responses) and completing the intrarespondent matrix template for each question (see Appendix I). The coding was discussed with the researcher's adviser. After establishing the sub-categories (strategies types), an expert in the area of research was asked to code the answers from the seven analyzed surveys to establish consensus regarding the code system to be used for analysis of the 
remaining surveys. A meeting was held to establish consensus regarding the coding system. Consensus was reached when both the researcher and the expert agreed on coding the same data. After consensus on the coding scheme was reached and the remaining data were collected, the researcher and the expert used the developed coding scheme to analyze one more response. Another meeting between the researcher and the expert was held to compare the results and resolve differences in coding.

The percent agreement was calculated as a measure of interrater reliability. This measure is the ratio of the number of items on which the raters agreed divided by the total number of items: ((Total number of agreements) / (Total number of observations)) X 100. An overall percentage agreement equal to or higher than $80 \%$ was desired. In this study an agreement of $85 \%$ was achieved.

A descriptive report was generated from the collected data containing text and tables (Cox, 1996; Fink, 1995a; Fink \& Kosecoff, 1985). As a result of data analysis a matrix of the most common strategies to address the high-level use of technology identified by the participants was generated. 


\section{CHAPTER IV: RESULTS}

This study was guided by two research questions. The first research question dealt with the identification of the indicators of high-level use of technology by professional development programs participating in this study. Data from the quantitative portion of the questionnaire were

analyzed, and the median was calculated in order to answer this question. The second question of this study addressed the identification of the strategies used by professional development programs to promote high-level use of instructional technology in participants' teaching practice. To answer this question, a qualitative analysis of the questionnaire's open-ended responses was conducted. The following is an in-depth description of the findings.

\section{Questionnaire Return Rate}

The potential participants of this study were 179 directors or their designees, awardees of the PT3 1999 and 2000 implementation grants, from all over the United States and its territories. From 179 potential participants, 64 were 1999 implementation grants whereas 115 were implementation grants awarded in 2000.

Data collection was conducted in the summer of 2004, and it lasted two weeks. At the end of the first week, a total of 25 (13.96\%) participants had responded to the questionnaire. Following a thank-you note to all potential participants (see Appendix E) and an e-mail reminder to non-respondents (see Appendix F), the number increased to $21(11.73 \%)$ more participants. After the final e-mail reminder (see Appendix G), 24 (13.41\%) more participants responded. A total of $70(39.11 \%)$ people responded to the questionnaire. From the 70 people who responded to the questionnaire, $19(27.14 \%)$ were those who received grants in 1999 whereas $46(65.71 \%)$ were those who received them in 2000, and 5 (7.14\%) could not be identified. A thank-you email was sent to each participant who completed the survey (see Appendix H). 
From 179 potential participants, 8 (4.47\%) forwarded the e-mail or indicated another person who could complete the questionnaire. Unfortunately, nine (5.02\%) participants refused to participate for the following reasons: (a) too busy, (b) on a field trip, (c) on vacation, (d) felt that their PT3 did not fit the research, (e) not part of the project any longer, or (f) program was not a success. There were $20(11.17 \%)$ of the 179 participants who could not be contacted. The e-mails sent came back as undelivered e-mails. Although further efforts were made to contact other people responsible for the project, the e-mail addresses listed on PT3 web site gave the same error. One participant, when trying to submit the questionnaire electronically, experienced technical problems and decided to print out the questionnaire to send it by mail. For a summary of the return rate see Table 9:

Table 9

Return Rate

Contact Attempts Number of Surveys Received Response Rate

Introduction e-mail 25

$13.97 \%$

Thank-you card/ incentive/ e-mail reminder

$11.73 \%$

Final e-mail reminder

24

$13.41 \%$

Total 70

$39.11 \%$

Findings Based on Research Questions

The following is the description of the findings from the two questions that guided this study. A brief statement of the analysis procedures involved in each of the questions is presented along with the research findings. 


\section{Research Question 1: Analyses and Findings}

Research Question 1: What do successful instructional technology professional development programs recognize as indicators of high-level use of technology? was answered by analyzing the data from the close-ended questions from the Pedagogical Use of Instructional Technology in Teaching Questionnaire (see Appendix B). The close-ended questions of the questionnaire were analyzed using a 5-point Likert scale in which the value of 1 was attributed to Strongly Disagree, 2 to Disagree, 3 to Not Applied in my Professional Development, 4 to Agree, and 5 to Strongly Agree. The percentage of the responses was calculated (see Appendix J) as well as the median (see Table 10).

Table 10

Recognized Indicators of High-level Use of Technology

\begin{tabular}{|c|c|c|c|c|}
\hline & $\begin{array}{c}\text { Questionnaire Items } \\
\text { Our professional development prepared participants to: }\end{array}$ & $n$ Valid & n Missing & Median \\
\hline 1. & $\begin{array}{l}\text { differentiate between appropriate and inappropriate uses of } \\
\text { technology for students' grade level and content area. }\end{array}$ & 70 & $\mathbf{0}$ & 4 \\
\hline 2. & $\begin{array}{l}\text { design and implement learning activities that integrate } \\
\text { technology to support and expand students' critical } \\
\text { thinking. }\end{array}$ & 70 & $\mathbf{0}$ & 4 \\
\hline 3. & $\begin{array}{l}\text { design and implement learning activities that integrate } \\
\text { technology to support and expand students' problem solving } \\
\text { skills. }\end{array}$ & 70 & $\mathbf{0}$ & 4 \\
\hline 4. & $\begin{array}{l}\text { design and implement learner-centered lessons that are } \\
\text { based on the current best practices for integrating the } \\
\text { learning of subject matter and student technology } \\
\text { standards. }\end{array}$ & 67 & 3 & 4 \\
\hline
\end{tabular}

\footnotetext{
* Items with a median lower than 3.5 were excluded from the list of high-level use of technology indicators.
} 
Table 10 (continued)

Recognized Indicators of High-level Use of Technology (Table 10 - continued)

\begin{tabular}{|c|c|c|c|c|}
\hline & $\begin{array}{c}\text { Questionnaire Items } \\
\text { Our professional development prepared participants to: }\end{array}$ & n Valid & n Missing & Median \\
\hline 5. & $\begin{array}{l}\text { assess learner-centered lessons that are based on the current } \\
\text { best practices for integrating subject matter and student } \\
\text { technology standards. }\end{array}$ & 69 & 1 & 4 \\
\hline 6. & $\begin{array}{l}\text { design and implement student-centered, instructional } \\
\text { materials that take advantage of computers to engage } \\
\text { students in their own learning. }\end{array}$ & 69 & 1 & 4 \\
\hline . & $\begin{array}{l}\text { design and teach technology-enriched learning activities that } \\
\text { connect content, state and national standards with student } \\
\text { technology standards. }\end{array}$ & 65 & 5 & 5 \\
\hline 8. & $\begin{array}{l}\text { design and teach technology-enriched learning activities that } \\
\text { meet the individual needs of students. }\end{array}$ & 69 & 1 & 4 \\
\hline 9. & $\begin{array}{l}\text { design an evaluation plan that applies multiple measures for } \\
\text { evaluating technology-based students' products. }\end{array}$ & 69 & 1 & 4 \\
\hline 10. & $\begin{array}{l}\text { participate in online professional collaborations with peers } \\
\text { and experts. }\end{array}$ & 70 & $\mathbf{0}$ & 4 \\
\hline 11. & $\begin{array}{l}\text { design and facilitate learning experiences that use assistive } \\
\text { technologies to meet the special physical needs of students. }\end{array}$ & 69 & 1 & $3^{*}$ \\
\hline 12. & $\begin{array}{l}\text { guide collaborative learning activities in which students use } \\
\text { technology resources to solve authentic problems in the } \\
\text { subject area (s). }\end{array}$ & 70 & $\mathbf{0}$ & 4 \\
\hline 13. & $\begin{array}{l}\text { arrange equitable access to appropriate technology } \\
\text { resources that enable students to engage successfully in } \\
\text { learning activities across subject/content areas and grade } \\
\text { levels. }\end{array}$ & 70 & $\mathbf{0}$ & 4 \\
\hline
\end{tabular}

\footnotetext{
Items with a median lower than 3.5 were excluded from the list of high-level use of technology indicators.
} 
Table 10 (continued)

Recognized Indicators of High-level Use of Technology

\begin{tabular}{|c|c|c|c|}
\hline $\begin{array}{c}\text { Questionnaire Items } \\
\text { Our professional development prepared participants to: }\end{array}$ & $n$ Valid & n Missing & Median \\
\hline $\begin{array}{l}\text { 14. plan and implement technology-based learning activities } \\
\text { that promote student engagement in analysis, synthesis, } \\
\text { interpretation, and creation of original products. }\end{array}$ & 69 & 1 & 4 \\
\hline $\begin{array}{l}\text { 15. facilitate students' use of technology that addresses their } \\
\text { social needs and cultural identity. }\end{array}$ & 67 & 3 & $3^{*}$ \\
\hline $\begin{array}{l}\text { 16. facilitate students' use of technology that promotes their } \\
\text { interaction with the global community. }\end{array}$ & 70 & $\mathbf{0}$ & $3^{*}$ \\
\hline $\begin{array}{l}\text { 17. structure a learning environment where student } \\
\text { collaboration is the common practice when using } \\
\text { technology. }\end{array}$ & 68 & 2 & 4 \\
\hline $\begin{array}{l}\text { 18. use students' interests, experiences when planning a variety } \\
\text { of computer-related activities. }\end{array}$ & 68 & 2 & 4 \\
\hline $\begin{array}{l}\text { 19. implement project-based learning that emphasizes critical } \\
\text { content and higher-order thinking skills (e.g., analysis, } \\
\text { synthesis, evaluation) using the available computers. }\end{array}$ & 68 & 2 & 4 \\
\hline $\begin{array}{l}\text { 20. design and implement web-based projects that emphasize } \\
\text { complex thinking skill strategies such as problem-solving, } \\
\text { scientific inquiry, or decision-making. }\end{array}$ & 65 & 5 & 4 \\
\hline $\begin{array}{l}\text { 21. guide students' use of the Internet for collaboration with } \\
\text { others. }\end{array}$ & 67 & 3 & 4 \\
\hline $\begin{array}{l}\text { 22. use content-specific tools (e.g., software, simulation, web } \\
\text { tools) to support learning. }\end{array}$ & 69 & 1 & 4 \\
\hline $\begin{array}{l}\text { 23. use technology resources to facilitate knowledge } \\
\text { construction. }\end{array}$ & 66 & 4 & 4 \\
\hline
\end{tabular}

\footnotetext{
Items with a median lower than 3.5 were excluded from the list of high-level use of technology indicators.
} 
Table 10 (continued)

Recognized Indicators of High-level Use of Technology

\begin{tabular}{|c|c|c|c|}
\hline $\begin{array}{l}\text { Questionnaire Items } \\
\text { Our professional development prepared participants to: } \\
\text { 24. apply technology tools and resources to collect, analyze, and } \\
\text { interpret data and report results. }\end{array}$ & $\begin{array}{l}n \text { Valid } \\
67\end{array}$ & $\begin{array}{l}n \text { Missing } \\
3\end{array}$ & $\begin{array}{c}\text { Median } \\
4\end{array}$ \\
\hline $\begin{array}{l}\text { 25. transfer what students' have learned in the classroom to real } \\
\text { world situation when planning the use of technology in the }\end{array}$ & 66 & 4 & $3^{*}$ \\
\hline $\begin{array}{l}\text { classroom(e.g., student-generated recycling program, } \\
\text { student-generated business). }\end{array}$ & & & \\
\hline $\begin{array}{l}\text { 26. design online collaborative projects with other entities (e.g., } \\
\text { schools, businesses, organizations) to find solutions, make } \\
\text { decisions, or seek a resolution to an issue of importance to }\end{array}$ & 68 & 2 & $3^{*}$ \\
\hline the students. & & & \\
\hline $\begin{array}{l}\text { 27. use technology in instruction to provide students with } \\
\text { increased levels of interactivity. }\end{array}$ & 69 & 1 & 4 \\
\hline
\end{tabular}

* Items with a median lower than 3.5 were excluded from the list of high-level use of technology indicators.

The items in the questionnaire that had a median above 3.5 were those indicators of highlevel use of technology recognized as part of participating professional development programs. Research Question 1 inquired about what indicators of high-level use of technology instructional technology professional development programs recognized as part of their programs. Analysis of the quantitative data presented in Table 10, indicated that from the 27 indicators of high-level use of technology a total of 22 were recognized as part of the professional development programs participating in this study.

\section{Research Question 2: Analyses and Findings}

Following the methods described in Chapter 3, the open-ended questions from the Pedagogical Use of Instructional Technology in Teaching Questionnaire (see Appendix B) were 
analyzed to answer Research Question 2: Which instructional technology professional development strategies successfully promote high-level use of instructional technology in participants' teaching practice? The analyses were divided into the following steps: (a) establishment of a coding scheme, (b) analysis of participants' responses per indicator, and (c) analysis of strategies across indicators. Following is an in-depth description of these steps. Establishment of Coding Scheme

The establishment of the coding scheme was divided into the following steps:

1. Content analysis of the first seven responses, which corresponded to $10 \%$ of the total responses, was conducted and a coding scheme was generated. The use of the intrarespondent matrix (see Appendix I) helped to organize the data, facilitating the analysis process.

2. The same set of questions was analyzed and coded by an expert in the area of research, and a meeting conducted in to compare the coding schemes generated from the analyses of the questions.

3. After discussing the differences in coding, a consensus was achieved resulting in the final coding scheme that was used to analyze the remainder of the responses.

4. This final coding scheme was tested by having the researcher and the expert code one additional question independently.

5. A final follow-up meeting was conducted to assess the reliability of the coding scheme. The resulting interrater reliability was $85 \%$.

A total of 28 codes were generated. During the process of analysis some codes were collapsed resulting in the 26 codes that are presented in Table 11. 


\section{Table 11}

Code Scheme - Strategies

\begin{tabular}{lll}
\hline Code & \multicolumn{1}{c}{ Strategies } & \multicolumn{1}{c}{ Description } \\
\hline 1. & $\begin{array}{l}\text { Identifying/Defining appropriate use } \\
\text { of IT }\end{array}$ & $\begin{array}{l}\text { Reasoning behind choosing a technology, and/or } \\
\text { learning theory involving the use of technology. }\end{array}$ \\
2. & Exemplars/Models/Experts & $\begin{array}{l}\text { Best examples of IT integration, including examples } \\
\text { given by experts and models developed by credible } \\
\text { institutes. }\end{array}$
\end{tabular}

3. Evaluation/Critique/Assessment

Assessment of technology use or the evaluation of any process involving the choice of IT implementation.

4. Observation

Observation of IT use by others.

5. Modeling

Providing example of IT use through their teaching.

6. Presentation/Demo/Hands on

Presenting the software/hardware, demonstrating its use and allowing time for hands on activities with the software/hardware that was introduced.

7. Examples

Example of work done (not necessarily excellent work in the area).

8. Mentoring/Consultation

Providing individual assistance and support.

9. Appropriate (Lesson/Learning Activity) Development

Development of lessons in which technology is used to contribute to the overall learning experience, with ITs that are chosen to support students' learning goal.

10. Referencing Standards

Standards were referenced but not taught directly.

11. Team Work/Group Discussion/Peer Discussion

Any kind of organized discussion that enhanced the learning experience, and/or any work done collaboratively.

12. Grouping

Facilitating the learning experience by directing activities to certain group that fits under certain criteria.

13. Appropriate lesson development and Development of lesson assessment was part of lesson assessment development plan. 


\section{Table 11}

Code Scheme - Strategies (Table 11 - continued)

\begin{tabular}{|c|c|c|}
\hline Code & Strategies & Description \\
\hline 14. & $\begin{array}{l}\text { Problem- Based Learning/Project- } \\
\text { Based Learning }\end{array}$ & $\begin{array}{l}\text { Learning Activities that promote problem-solving } \\
\text { and/or project based learning. i.e: WebQuest. }\end{array}$ \\
\hline 15. & Standards Specific Training & $\begin{array}{l}\text { Formal training on standards and how to better } \\
\text { address them. }\end{array}$ \\
\hline 16. & Present/Develop/Use Rubrics & Any kind of activity that involves rubrics. \\
\hline 17. & Special Funding/Special Incentives & $\begin{array}{l}\text { Financial funding or special incentives awarded to } \\
\text { those participating in the professional development } \\
\text { program. }\end{array}$ \\
\hline 18. & Collaborative Learning & $\begin{array}{l}\text { Any activity that promotes collaborate learning, } \\
\text { except the ones involving telecollaboration. }\end{array}$ \\
\hline 19. & Telecollaboration & $\begin{array}{l}\text { Relates to the telecollaborative activities classified } \\
\text { by Judi Harris (see Table 1). }\end{array}$ \\
\hline 20. & Made Technology Available & Any effort towards providing software and hardware. \\
\hline 21. & Technology Support Teams & Offering technical support during and after training. \\
\hline 22. & Specific Assessment Tool & Development/use of a specific assessment tool. \\
\hline 23. & $\begin{array}{l}\text { Faculty Research } \\
\text { (Presentations/Conferences) }\end{array}$ & $\begin{array}{l}\text { Require participants to present their work and/or } \\
\text { participate in conferences. }\end{array}$ \\
\hline 24. & Course/Curriculum Modification & $\begin{array}{l}\text { Adapted a course/curriculum to address the use of } \\
\text { instructional technology. }\end{array}$ \\
\hline 25. & Resources Development & $\begin{array}{l}\text { Development of instructional technology activities } \\
\text { that could later be used by others in the field. }\end{array}$ \\
\hline 26. & Lesson Implementation & $\begin{array}{l}\text { Lessons that were developed and then implemented } \\
\text { into participants' teaching. }\end{array}$ \\
\hline
\end{tabular}

\section{Analysis of Participants' Responses per Indicator}

In order to better answer Research Question 2, the responses for all 27 indicators were analyzed, including the five indicators that did not make the final list of high-level use of 
technology indicators. The analysis of all 27 indicators was done to ensure that all successful strategies described by professional development programs were captured.

Table 12 shows the number of participants who answered Agree or Strongly Agree to an indicator and the number of participants who provided responses to the open-ended questions. For all questions, participants were asked to respond to those open-ended questions if they Agree or Strongly Agree, however, not all of them did. Therefore, the number of participants marking Agree or Strongly Agree and the number of open-ended responses differ for each indicator. For instance, as shown in Table 12, from the 70 participants of this study 53 answered Agree or Strongly Agree to indicator 1. Although it was expected that all 53 would provide the strategies that they used to address indicator one, only $51 \mathrm{did}$.

Thus, because there are discrepancies in the number of participants who marked Agree or Strongly Agree and the number of open-ended responses, any calculation involving number of responses used the values from the number of responses to the open-ended reponses column in Table 12.

Table 12

Number of Responses per Indicator

\begin{tabular}{llc}
\hline \multicolumn{1}{c}{ Indicators } & $\begin{array}{c}\text { Number and } \\
\text { Percentages of } \\
\text { Agreed/Strongly } \\
\text { Agreed Reponses }\end{array}$ & $\begin{array}{c}\text { Number and } \\
\text { Percentage of } \\
\text { Open-Ended } \\
\text { Responses }\end{array}$ \\
\hline $1 . \quad \begin{array}{l}\text { differentiate between appropriate and inappropriate uses of } \\
\text { technology for students' grade level and content area. }\end{array}$ & $53(75.71 \%)$ & $51(72.86 \%)$ \\
\hline $2 . \quad \begin{array}{l}\text { design and implement learning activities that integrate technology } \\
\text { to support and expand students' critical thinking. }\end{array}$ & $63(90.00 \%)$ & $60(85.71 \%)$ \\
\hline $3 . \quad \begin{array}{l}\text { design and implement learning activities that integrate technology } \\
\text { to support and expand students' problem solving skills. }\end{array}$ & $63(90.00 \%)$ & $56(80.00 \%)$ \\
\hline $4 . \quad \begin{array}{l}\text { design and implement learner-centered lessons that are based on } \\
\text { the current best practices for integrating the learning of subject } \\
\text { matter and student technology standards. }\end{array}$ & $57(81.43 \%)$ & $51(72.86 \%)$ \\
\hline
\end{tabular}


Table 12 (continued)

Number of Responses per Indicator

\begin{tabular}{|c|c|c|}
\hline Indicators & $\begin{array}{l}\text { Number and } \\
\text { Percentages of } \\
\text { Agree/Strongly } \\
\text { Agree Reponses }\end{array}$ & $\begin{array}{l}\text { Number and } \\
\text { Percentages of } \\
\text { Open-Ended } \\
\text { Responses }\end{array}$ \\
\hline $\begin{array}{l}\text { 5. assess learner-centered lessons that are based on the current best } \\
\text { practices for integrating subject matter and student technology } \\
\text { standards. }\end{array}$ & $44(62.86 \%)$ & $41(58.57 \%)$ \\
\hline $\begin{array}{l}\text { 6. design and implement student-centered, instructional materials } \\
\text { that take advantage of computers to engage students in their own } \\
\text { learning. }\end{array}$ & $57(81.43 \%)$ & $49(70.00 \%)$ \\
\hline $\begin{array}{l}\text { 7. design and teach technology-enriched learning activities that } \\
\text { connect content, state and national standards with student } \\
\text { technology standards. }\end{array}$ & $56(80.00 \%)$ & $53(75.71 \%)$ \\
\hline $\begin{array}{l}\text { 8. design and teach technology-enriched learning activities that meet } \\
\text { the individual needs of students. }\end{array}$ & $54(77.14 \%)$ & $40(57.14 \%)$ \\
\hline $\begin{array}{l}\text { 9. design an evaluation plan that applies multiple measures for } \\
\text { evaluating technology-based students' products. }\end{array}$ & $35(50.00 \%)$ & $28(40.00 \%)$ \\
\hline $\begin{array}{l}\text { 10. participate in online professional collaborations with peers and } \\
\text { experts. }\end{array}$ & $41(58.57 \%)$ & $33(47.14 \%)$ \\
\hline $\begin{array}{l}\text { 11. design and facilitate learning experiences that use assistive } \\
\text { technologies to meet the special physical needs of students. }\end{array}$ & $34(48.57 \%)$ & $25(35.72 \%)$ \\
\hline $\begin{array}{l}\text { 12. guide collaborative learning activities in which students use } \\
\text { technology resources to solve authentic problems in the subject } \\
\text { area (s). }\end{array}$ & $52(74.29 \%)$ & $42(60.00 \%)$ \\
\hline $\begin{array}{l}\text { 13. arrange equitable access to appropriate technology resources that } \\
\text { enable students to engage successfully in learning activities across } \\
\text { subject/content areas and grade levels. }\end{array}$ & $40(57.14 \%)$ & $27(38.57 \%)$ \\
\hline $\begin{array}{l}\text { 14. plan and implement technology-based learning activities that } \\
\text { promote student engagement in analysis, synthesis, interpretation, } \\
\text { and creation of original products. }\end{array}$ & $54(77.14 \%)$ & $41(58.57 \%)$ \\
\hline $\begin{array}{l}\text { 15. facilitate students' use of technology that addresses their social } \\
\text { needs and cultural identity. }\end{array}$ & $28(40.00 \%)$ & $15(21.43 \%)$ \\
\hline $\begin{array}{l}\text { 16. facilitate students' use of technology that promotes their } \\
\text { interaction with the global community. }\end{array}$ & $33(47.14 \%)$ & $21(30.00 \%)$ \\
\hline
\end{tabular}


Table 12 (continued)

Number of Responses per Indicator

\begin{tabular}{|c|c|c|}
\hline Indicators & $\begin{array}{l}\text { Number and } \\
\text { Percentages of } \\
\text { Agree/Strongly } \\
\text { Agree Reponses }\end{array}$ & $\begin{array}{l}\text { Number and } \\
\text { Percentages of } \\
\text { Open-Ended } \\
\text { Responses } \\
\end{array}$ \\
\hline $\begin{array}{l}\text { 17. structure a learning environment where student collaboration is } \\
\text { the common practice when using technology. }\end{array}$ & $54(77.14 \%)$ & $37(52.86 \%)$ \\
\hline $\begin{array}{l}\text { 18. use students' interests, experiences when planning a variety of } \\
\text { computer-related activities. }\end{array}$ & $45(64.29 \%)$ & $33(47.14 \%)$ \\
\hline $\begin{array}{l}\text { 19. implement project-based learning that emphasizes critical content } \\
\text { and higher-order thinking skills (e.g., analysis, synthesis, } \\
\text { evaluation) using the available computers. }\end{array}$ & $48(68.57 \%)$ & $29(41.43 \%)$ \\
\hline $\begin{array}{l}\text { 20. design and implement web-based projects that emphasize } \\
\text { complex thinking skill strategies such as problem-solving, } \\
\text { scientific inquiry, or decision-making. }\end{array}$ & $41(58.57 \%)$ & $29(41.43 \%)$ \\
\hline 21. guide students' use of the Internet for collaboration with others. & $40(57.14 \%)$ & $26(37.14 \%)$ \\
\hline $\begin{array}{l}\text { 22. use content-specific tools (e.g., software, simulation, web tools) to } \\
\text { support learning. }\end{array}$ & $61(87.14 \%)$ & $46(65.71 \%)$ \\
\hline 23. use technology resources to facilitate knowledge construction. & $50(71.43 \%)$ & $30(42.86 \%)$ \\
\hline $\begin{array}{l}\text { 24. apply technology tools and resources to collect, analyze, and } \\
\text { interpret data and report results. }\end{array}$ & $47(67.14 \%)$ & $32(45.71 \%)$ \\
\hline $\begin{array}{l}\text { 25. transfer what students' have learned in the classroom to real } \\
\text { world situation when planning the use of technology in the } \\
\text { classroom(e.g., student-generated recycling program, student- } \\
\text { generated business). }\end{array}$ & $25(35.71 \%)$ & $16(22.86 \%)$ \\
\hline $\begin{array}{l}\text { 26. design online collaborative projects with other entities (e.g., } \\
\text { schools, businesses, organizations) to find solutions, make } \\
\text { decisions, or seek a resolution to an issue of importance to the } \\
\text { students. }\end{array}$ & $24(34.29 \%)$ & $13(18.57 \%)$ \\
\hline $\begin{array}{l}\text { 27. use technology in instruction to provide students with increased } \\
\text { levels of interactivity. }\end{array}$ & $46(65.71 \%)$ & $30(42.86 \%)$ \\
\hline
\end{tabular}

Intrarespondent and interrespondent matrixes - Analyses of participants' choice of

strategies per indicator. As a means for an efficient analysis of qualitative data, Onwuegbuzie

and Teddlie (2003) suggested the use of intrarespondent matrices for coding purposes and the 
use of interrespondent matrices for the purpose of analysis. Therefore, for each indicator, an intrarespondent matrix was used to organize the open-ended responses for coding (see Appendix I). During the process of coding, participants were assigned codes in order to assure their anonymity.

Following the coding process an interrespondent matrix was generated for each of the 27 indicators with the purpose of better visualizing and understanding the results of coding. "The interrespondent matrix indicates which individuals contribute to each emerging theme" (Onwuegbuzie \& Teddlie, 2003, p. 356). From the analysis of participants' responses the researcher could determine when a strategy was mentioned by a participant (see Appendix K). A value of one was attributed to a strategy if it was present in the participant's response; otherwise a value of zero was attributed to the strategy. Participants could choose more than one strategy to address a particular indicator. Table 13 shows the interrespondent matrix template used in this study and Table 14 gives an example on how the template was used. 
Table 13

Interrespondent Matrix Template

Indicator \#: Indicator statement.

\section{Strategies Addressed in Indicator \#}

\begin{tabular}{|c|c|c|c|c|}
\hline $\begin{array}{c}\text { Participants } \\
\text { (code of participants } \\
\text { who responded to the } \\
\text { question) }\end{array}$ & 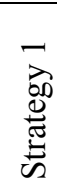 & 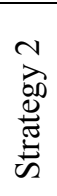 & 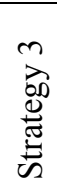 & 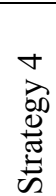 \\
\hline & & & & \\
\hline $\begin{array}{c}\text { Percentage (sum of } 1 \mathrm{~s} \\
\text { related to the strategy/ } \\
\text { number of responses) X } \\
100\end{array}$ & & & & \\
\hline
\end{tabular}

Table 14

Example of Interrespondent Matrix Analysis

Indicator 1: O ur professional development program prepared participants to differentiate between appropriate and inappropriate uses of technology for students' grade level and content area. If you Agreed or Strongly Agreed with this statement please list the strategy(ies) that you used to accomplish it.

\section{Strategies Addressed in Indicator 1}

\begin{tabular}{|c|c|c|c|c|}
\hline Participants' Code & 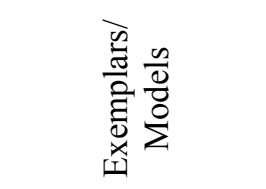 & $\begin{array}{l}\tilde{0} \\
\stackrel{0}{0} \\
D_{0}^{0} \\
0 \\
0 \\
0\end{array}$ & $\begin{array}{l}\stackrel{\infty}{:} \\
\frac{0}{0} \\
\frac{0}{2}\end{array}$ & 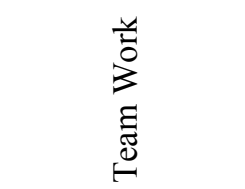 \\
\hline Participant 1 & 0 & 1 & 1 & 0 \\
\hline Participant 4 & 1 & 1 & 1 & 1 \\
\hline $\begin{array}{c}\text { Percentage of } \\
\text { participants selecting a } \\
\text { strategy }\end{array}$ & $1 / 2 \times 100=50 \%$ & $2 / 2 \times 100=100 \%$ & $2 / 2 \times 100=100 \%$ & $1 / 2 \times 100=50 \%$ \\
\hline
\end{tabular}

The example in Table 14 leads to the following conclusion: Participant 1 chose

Observation and Modeling to address Indicator 1, whereas Participant 4 chose

Exemplars/Models, Observation, Modeling, and Team Work as the strategies to address Indicator

1. In the example provided in Table 14, there were only two responses for indicator one. 
For each strategy the percentage was calculated by summing the number of participants who selected a particular strategy, dividing the result by the total number of responses to that indicator, which in this case was 2 , and multiplying it by 100 . This procedure was followed to analyze the indicators separately. A sample analysis of raw data for indicators 1, 2, and 3 is found in Appendix K.

Summarizing interrespondent results. Table 15, summarizes the analysis of all raw data and shows the percentage of strategy use per indicator. Table 15 provides a better visualization and assessment of the levels of use of a strategy per indicator. To distinguish among levels of use, there was a need to determine a suitable range. The procedures used to determine this range are as follows:

1. Natural data cut-offs were determined. By analyzing the data in Table 15, the researcher found that the maximum percentage of use of a strategy for an indicator was $82 \%$, and the minimum was $0 \%$. Since the study focused on those strategies used, the value of $0 \%$ was not considered when determining the range. Thus, the range of percentage usage was set as $1 \%$ to $82 \%$.

2. The mid-point in the range was determined to be $41 \%$, and data were organized into two columns: percentages above and below $41 \%$. When divided into these two columns, the data revealed that only 16 out of the 702 percentages presented in Table 15 were above $41 \%$, with the remaining 686 below $41 \%$.

3. The final range used to analyze the data on Table 15 was: 1-10, 11-20, 21-30, 31-40, and $>41$.

4. The range intervals were classified in the following manner: $>40$ Very Often Used, 40-31 Often Used, 30-21 Occasionally Used, 20-11 Rarely Used, 10-1 Very Rarely Used. 
This classification allowed the data from Table 15 to be read in the following manner: Looking at Indicator 2 (I-2) in the second row of Table $15,42 \%$ of the total number of participants who responded to the open-ended question for Indicator 2 used Strategy 9 to address this particular indicator. According to the established ranges of percentage, $42 \%$ is classified as Very Often Used. Therefore, the results suggest that Strategy 9 was used very often to address Indicator 2. On the other hand, Strategy 4 was only used by $2 \%$ of the participants who provided open-ended responses to this particular indicator, classifying it as a Rarely Used strategy for Indicator 2. 
Table 15

Percentage of Strategies Used per Indicator

\begin{tabular}{|c|c|c|c|c|c|c|c|c|c|c|c|c|c|c|c|c|c|c|c|c|c|c|c|c|c|c|}
\hline 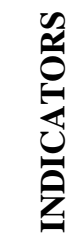 & & م્ & 趈 & 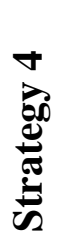 & مِ & 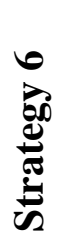 & م) & 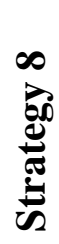 & 品 & 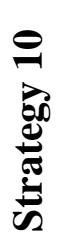 & 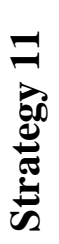 & 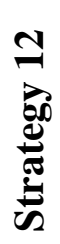 & 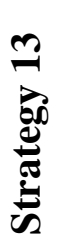 & 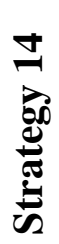 & 号 & 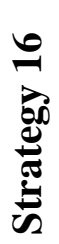 & 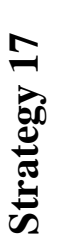 & 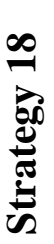 & 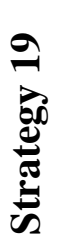 & 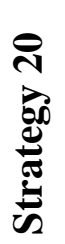 & 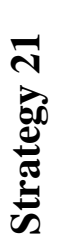 & 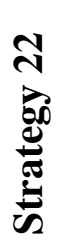 & 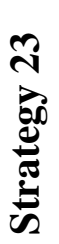 & 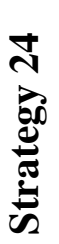 & 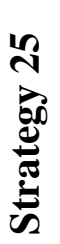 & 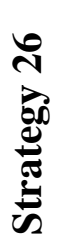 \\
\hline I-1 & 45 & 4 & 39 & 4 & 4 & 22 & 4 & 8 & 27 & 22 & 8 & 10 & 2 & 6 & 0 & 2 & 4 & 0 & 0 & 4 & 2 & 8 & 2 & 0 & 0 & 10 \\
\hline I-2 & 42 & 7 & 30 & 2 & 8 & 22 & 5 & 10 & 42 & 3 & 8 & 3 & 2 & 17 & 0 & 0 & 5 & 2 & 0 & 3 & 5 & 2 & 2 & 0 & 0 & 15 \\
\hline I-3 & 13 & 4 & 23 & 2 & 14 & 20 & 4 & 11 & 46 & 2 & 11 & 4 & 4 & 18 & 0 & 2 & 4 & 2 & 2 & 0 & 9 & 5 & 2 & 2 & 0 & 11 \\
\hline I-4 & 18 & 16 & 20 & 2 & 14 & 18 & 12 & 6 & 45 & 24 & 6 & 0 & 4 & 8 & 4 & 0 & 0 & 4 & 0 & 0 & 2 & 0 & 2 & 2 & 4 & 14 \\
\hline I-5 & 5 & 20 & 34 & 2 & 2 & 10 & 5 & 5 & 17 & 39 & 2 & 0 & 20 & 2 & 5 & 20 & 0 & 2 & 0 & 0 & 2 & 12 & 0 & 0 & 2 & 12 \\
\hline I-6 & 12 & 8 & 16 & 4 & 14 & 18 & 8 & 6 & 47 & 6 & 10 & 0 & 0 & 18 & 0 & 4 & 4 & 4 & 0 & 2 & 6 & 0 & 2 & 4 & 10 & 10 \\
\hline I-7 & 6 & 6 & 21 & 0 & 4 & 13 & 8 & 4 & 36 & 77 & 8 & 2 & 19 & 2 & 6 & 4 & 2 & 2 & 2 & 0 & 2 & 0 & 0 & 6 & 4 & 19 \\
\hline I-8 & 18 & 8 & 30 & 0 & 5 & 20 & 15 & 8 & 53 & 13 & 3 & 3 & 0 & 5 & 0 & 8 & 3 & 3 & 3 & 5 & 3 & 5 & 0 & 3 & 0 & 13 \\
\hline I-9 & 7 & 4 & 39 & 0 & 4 & 11 & 4 & 0 & 0 & 4 & 0 & 0 & 25 & 0 & 4 & 46 & 0 & 0 & 0 & 0 & 0 & 11 & 0 & 0 & 0 & 4 \\
\hline I-10 & 3 & 0 & 0 & 0 & 3 & 12 & 0 & 3 & 9 & 0 & 0 & 0 & 0 & 0 & 0 & 0 & 9 & 6 & 82 & 9 & 3 & 0 & 0 & 0 & 3 & 0 \\
\hline I-11 & 20 & 8 & 4 & 0 & 4 & 20 & 12 & 16 & 20 & 0 & 0 & 8 & 0 & 0 & 0 & 0 & 8 & 8 & 8 & 16 & 0 & 0 & 0 & 0 & 0 & 0 \\
\hline I-12 & 14 & 17 & 12 & 0 & 19 & 17 & 12 & 10 & 21 & 2 & 5 & 2 & 0 & 33 & 0 & 0 & 2 & 7 & 5 & 0 & 0 & 0 & 0 & 5 & 5 & 10 \\
\hline
\end{tabular}

Percentage Range: >40 Very Often Used, 40-31 Often Used, 30-21 Occasionally Used, 20-11 Rarely Used, 10-1 Very Rarely Used 
Table 15 (continued)

Percentage of Strategies Used per Indicator

\begin{tabular}{|c|c|c|c|c|c|c|c|c|c|c|c|c|c|c|c|c|c|c|c|c|c|c|c|c|c|c|}
\hline 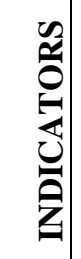 & 吾 & 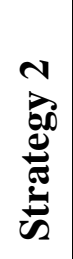 & 艿 & & 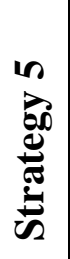 & 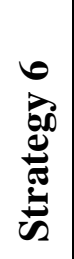 & مَ & 苞 & 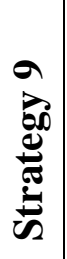 & 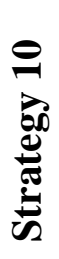 & 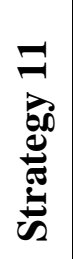 & 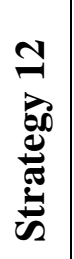 & م) & 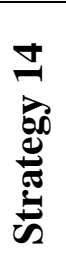 & 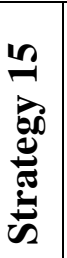 & 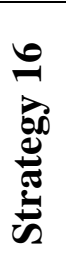 & 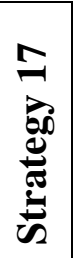 & 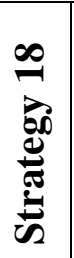 & 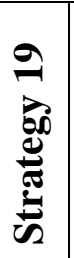 & 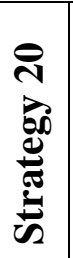 & 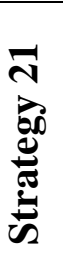 & 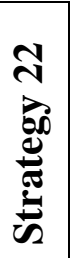 & 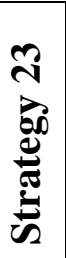 & 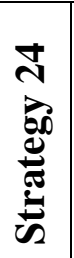 & 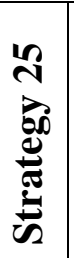 & 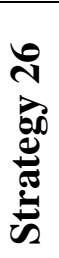 \\
\hline I-13 & 26 & 7 & 11 & 0 & 4 & 19 & 7 & 7 & 0 & 4 & 11 & 0 & 0 & 7 & 0 & 0 & 4 & 4 & 4 & 41 & 0 & 0 & 0 & 0 & 0 & 4 \\
\hline I-14 & 22 & 20 & 15 & 2 & 10 & 20 & 12 & 7 & 46 & 7 & 7 & 0 & 2 & 22 & 0 & 7 & 7 & 5 & 5 & 2 & 5 & 0 & 0 & 0 & 0 & 17 \\
\hline I-15 & 27 & 7 & 7 & 0 & 7 & 33 & 7 & 27 & 27 & 0 & 13 & 0 & 0 & 7 & 0 & 0 & 7 & 7 & 7 & 0 & 7 & 0 & 0 & 0 & 7 & 20 \\
\hline I-16 & 24 & 14 & 14 & 0 & 0 & 19 & 0 & 10 & 5 & 0 & 0 & 0 & 0 & 10 & 0 & 0 & 0 & 10 & 43 & 0 & 5 & 0 & 5 & 0 & 0 & 5 \\
\hline I-17 & 22 & 8 & 8 & 0 & 16 & 16 & 5 & 11 & 14 & 3 & 16 & 0 & 0 & 16 & 0 & 0 & 5 & 14 & 11 & 8 & 8 & 0 & 0 & 0 & 0 & 5 \\
\hline I-18 & 12 & 9 & 15 & 0 & 15 & 15 & 6 & 15 & 36 & 3 & 9 & 0 & 0 & 12 & 0 & 0 & 3 & 3 & 3 & 0 & 3 & 0 & 0 & 3 & 0 & 12 \\
\hline I-19 & 14 & 14 & 24 & 0 & 28 & 31 & 17 & 3 & 28 & 7 & 3 & 0 & 0 & 24 & 0 & 3 & 0 & 3 & 0 & 0 & 0 & 0 & 0 & 0 & 0 & 7 \\
\hline I-20 & 10 & 7 & 7 & 0 & 3 & 17 & 14 & 3 & 52 & 3 & 7 & 0 & 0 & 55 & 0 & 0 & 0 & 0 & 10 & 0 & 3 & 0 & 0 & 3 & 0 & 17 \\
\hline I-21 & 27 & 4 & 15 & 0 & 4 & 15 & 8 & 4 & 8 & 0 & 12 & 0 & 0 & 12 & 0 & 0 & 0 & 19 & 46 & 0 & 4 & 4 & 0 & 0 & 0 & 12 \\
\hline I-22 & 28 & 7 & 13 & 0 & 7 & 39 & 7 & 11 & 24 & 0 & 7 & 0 & 0 & 11 & 0 & 0 & 2 & 0 & 0 & 7 & 4 & 0 & 0 & 4 & 4 & 20 \\
\hline I-23 & 23 & 7 & 13 & 0 & 17 & 23 & 10 & 7 & 27 & 0 & 10 & 0 & 0 & 13 & 0 & 0 & 0 & 0 & 3 & 0 & 3 & 0 & 0 & 7 & 0 & 20 \\
\hline I-24 & 9 & 6 & 34 & 0 & 6 & 25 & 9 & 9 & 16 & 3 & 6 & 3 & 0 & 3 & 0 & 3 & 0 & 0 & 0 & 0 & 0 & 19 & 9 & 0 & 0 & 13 \\
\hline I-25 & 13 & 13 & 19 & 0 & 25 & 25 & 19 & 31 & 25 & 6 & 6 & 6 & 0 & 13 & 0 & 0 & 0 & 0 & 0 & 6 & 6 & 6 & 0 & 0 & 0 & 25 \\
\hline I-26 & 8 & 0 & 8 & 0 & 23 & 23 & 23 & 8 & 8 & 0 & 0 & 0 & 0 & 0 & 0 & 0 & 0 & 8 & 38 & 8 & 8 & 8 & 0 & 0 & 0 & 15 \\
\hline I-27 & 20 & 7 & 7 & 0 & 17 & 7 & 17 & 7 & 20 & 0 & 10 & 3 & 0 & 13 & 0 & 0 & 0 & 3 & 17 & 0 & 0 & 0 & 0 & 3 & 0 & 13 \\
\hline
\end{tabular}

Percentage Range: $>40$ Very Often Used, 40-31 Often Used, 30-21 Occasionally Used, 20-11 Rarely Used, 10-1 Very Rarely Used 
By analyzing the data from Table 15 the top strategies used to address each indicator could be identified. As an example, for Indicator 20 (I-20), Strategy 9 was used by $52 \%$ of the participants who provided open-ended responses to Indicator 20, and Strategy 14 was used by $55 \%$ of those participants who provided open-ended responses to this indicator, classifying these strategies as those Very Often Used for this particular indicator. On the other hand, Strategies 6, 7 , and 26 were used by $17 \%, 14 \%$, and $17 \%$ respectively of the participants who provided openended responses to Indicator 20, classifying these strategies as those Rarely Used for this particular indicator. Strategies used for each of the indicators were ranked based on their level of use as determined by the established range intervals (see Appendix L). The analysis of Table 15 showed that Indicators 11 (I-11) and 27 (I-27) were the only two indicators in which all the strategies used fell within the ranges of Rarely Used and Very Rarely Used.

In order to have an understanding of the number of strategies used per indicator and the number of strategies in a given range interval, the data from Table 15, were redisplayed in Table 16. Table 16 can be read in the following manner: For Indicator 4 (I-4) out of the 26 strategies, a total of 20 were used to address that particular indicator: one strategy was Very Often Used (>40\%), one strategy was Occasionally Used (30\%-21\%), seven were Rarely Used (20\%-11\%), and 11 were Very Rarely Used (10\%-1\%) by the participants who answered to this specific indicator. 
Table 16

Summary of Frequency of Strategies Used per Ranges

\begin{tabular}{|c|c|c|c|c|c|}
\hline Indicators & $\begin{array}{c}>40 \\
\text { Very Often Used }\end{array}$ & $\begin{array}{c}\text { 40-31 } \\
\text { Often Used }\end{array}$ & $\begin{array}{c}30-21 \\
\text { Occasionally } \\
\text { Used }\end{array}$ & $\begin{array}{c}\text { 20-11 } \\
\text { Rarely Used }\end{array}$ & $\begin{array}{c}10-1 \\
\text { Very Rarely } \\
\text { Used }\end{array}$ \\
\hline I-1 & 1 & 1 & 3 & 0 & 16 \\
\hline I-2 & 2 & 0 & 2 & 2 & 15 \\
\hline I-3 & 1 & 0 & 1 & 7 & 14 \\
\hline I-4 & 1 & 0 & 1 & 7 & 11 \\
\hline I-5 & 0 & 2 & 0 & 6 & 12 \\
\hline I-6 & 1 & 0 & 0 & 5 & 15 \\
\hline I-7 & 1 & 1 & 1 & 3 & 16 \\
\hline I-8 & 1 & 0 & 1 & 5 & 14 \\
\hline I-9 & 1 & 1 & 1 & 2 & 7 \\
\hline I-10 & 1 & 0 & 0 & 1 & 9 \\
\hline I-11 & 0 & 0 & 0 & 6 & 7 \\
\hline I-12 & 0 & 1 & 1 & 6 & 10 \\
\hline I-13 & 1 & 0 & 1 & 3 & 10 \\
\hline I-14 & 1 & 0 & 3 & 4 & 12 \\
\hline I-15 & 0 & 1 & 3 & 2 & 10 \\
\hline I-16 & 1 & 1 & 0 & 3 & 7 \\
\hline I-17 & 0 & 0 & 0 & 8 & 8 \\
\hline I-18 & 0 & 0 & 0 & 7 & 9 \\
\hline I-19 & 0 & 1 & 4 & 3 & 6 \\
\hline I-20 & 2 & 0 & 0 & 3 & 10 \\
\hline I-21 & 1 & 0 & 1 & 6 & 7 \\
\hline I-22 & 0 & 1 & 2 & 4 & 9 \\
\hline I-23 & 0 & 0 & 3 & 4 & 7 \\
\hline I-24 & 0 & 1 & 1 & 3 & 11 \\
\hline I-25 & 0 & 1 & 4 & 5 & 6 \\
\hline I-26 & 0 & 1 & 3 & 1 & 8 \\
\hline I-27 & 0 & 0 & 0 & 7 & 8 \\
\hline
\end{tabular}

The data presented in the first three columns of Table 16 suggest that there were only selected few strategies used by a large number of professional development programs to address 
certain indicators. Contrasting with the large number of strategies that fell within the last two columns of Table 16, suggesting that the majority of strategies for an indicator were used by a low number of professional developments to address their specific context needs.

Analyses of Strategies Across Indicators

Research Question 2 inquires about the strategies used to promote successful integration of technology in teaching. Although the data from the analysis of the strategies use per indicator offers us important information it does not show the strategies most used to address a different number of indicators. To identify the most often used strategies overall, data needed to be analyzed across indicators. The differences in the intensity of use of a strategy across indicators led to the necessity of assigning weighted values to the percentages in Table 15. Table 17 shows the weighted values assigned to the range intervals.

Table 17

Weighted Values Assigned to the Range Intervals

\begin{tabular}{ccc}
\hline Weighted Values & Range Intervals & $\begin{array}{c}\text { Total Number of Percentages per } \\
\text { Range Intervals }\end{array}$ \\
\hline $\mathbf{5}$ & $41 \%-82 \%$ (Very Often Used) & 16 \\
$\mathbf{4}$ & $31 \%-40 \%$ (Often Used) & 13 \\
$\mathbf{3}$ & $21 \%-30 \%$ (Occasionally Used) & 37 \\
$\mathbf{2}$ & $11 \%-20 \%$ (Rarely Used) & 115 \\
$\mathbf{1}$ & $1 \%-10 \%$ (Very Rarely Used) & 272 \\
\hline
\end{tabular}

The assignment of the weighted values to the percentages in Table 15 is represented in Table 18. Table 18 can be read in the following manner: For Indicator 2 (I-2) more than $40 \%$ of the total number of participants who provided open-ended responses to Indicator 2 used Strategy 
9; therefore, weight of 5 was assigned to that strategy. At the other extreme, for the same indicator Strategy 4 received a 1 because it was used by less than $10 \%$ of the total number of participants who provided open-ended responses to Indicator 2.

After assigning weighted values to the percentages, sums were calculated for each strategy across all indicators. The results of the sum of weights are represented in the last line of Table 18. To determine the overall strength of each strategy a range based on the sum of weights was established. The following steps were taken to establish the range:

1. Natural data cut-offs were determined. By analyzing the sum of weights in the last line of Table 18 the researcher found that the highest value resulting from the sum of weights of a strategy was 78 , and the lowest was 4 . Thus, the range was determined to be 4 to 78 ;

2. The range was then divided into quartiles which allowed the distinction of a strategy's level of use across indicators: 78-60 Very Often Used, 59-41 Often Used, 40-22 Occasionally Used, and 21-4 Rarely Used. 
Table 18

Weight Assigned to the Percentage of Strategies Used per Indicator

\begin{tabular}{|c|c|c|c|c|c|c|c|c|c|c|c|c|c|c|c|c|c|c|c|c|c|c|c|c|c|c|}
\hline 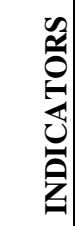 & 苞 & ڤ્م & 承 & 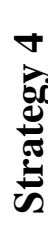 & 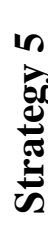 & 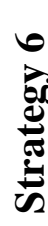 & 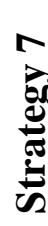 & 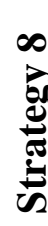 & م) & 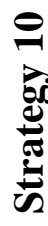 & 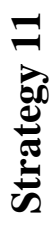 & 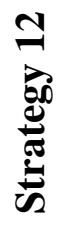 & 承 & 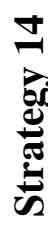 & 임 & 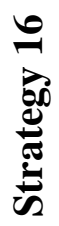 & స్요 & 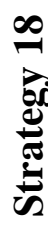 & مَ & 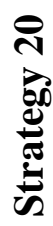 & 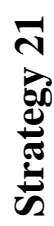 & 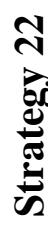 & 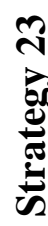 & 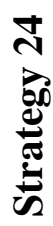 & 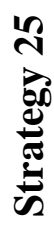 & 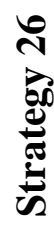 \\
\hline I-1 & 5 & 1 & 4 & 1 & 1 & 3 & 1 & 1 & 3 & 3 & 1 & 1 & 1 & 1 & 0 & 1 & 1 & 0 & 0 & 1 & 1 & 1 & 1 & 0 & 0 & 1 \\
\hline I-2 & 5 & 1 & 3 & 1 & 1 & 3 & 1 & 1 & 5 & 1 & 1 & 1 & 1 & 2 & 0 & 0 & 1 & 1 & 0 & 1 & 1 & 1 & 1 & 0 & 0 & 2 \\
\hline I-3 & 2 & 1 & 3 & 1 & 2 & 2 & 1 & 2 & 5 & 1 & 2 & 1 & 1 & 2 & 0 & 1 & 1 & 1 & 1 & 0 & 1 & 1 & 1 & 1 & 0 & 2 \\
\hline I-4 & 2 & 2 & 2 & 1 & 2 & 2 & 2 & 1 & 5 & 3 & 1 & 0 & 1 & 1 & 1 & 0 & 0 & 1 & 0 & 0 & 1 & 0 & 1 & 1 & 1 & 2 \\
\hline I-5 & 1 & 2 & 4 & 1 & 1 & 1 & 1 & 1 & 2 & 4 & 1 & 0 & 2 & 1 & 1 & 2 & 0 & 1 & 0 & 0 & 1 & 2 & 0 & 0 & 1 & 2 \\
\hline I-6 & 2 & 1 & 2 & 1 & 2 & 2 & 1 & 1 & 5 & 1 & 1 & 0 & 0 & 2 & 0 & 1 & 1 & 1 & 0 & 1 & 1 & 0 & 1 & 1 & 1 & 1 \\
\hline I-7 & 1 & 1 & 3 & 0 & 1 & 2 & 1 & 1 & 4 & 5 & 1 & 1 & 2 & 1 & 1 & 1 & 1 & 1 & 1 & 0 & 1 & 0 & 0 & 1 & 1 & 2 \\
\hline I-8 & 2 & 1 & 3 & 0 & 1 & 2 & 2 & 1 & 5 & 2 & 1 & 1 & 0 & 1 & 0 & 1 & 1 & 1 & 1 & 1 & 1 & 1 & 0 & 1 & 0 & 2 \\
\hline I-9 & 1 & 1 & 4 & 0 & 1 & 2 & 1 & 0 & 0 & 1 & 0 & 0 & 3 & 0 & 1 & 5 & 0 & 0 & 0 & 0 & 0 & 2 & 0 & 0 & 0 & 1 \\
\hline I-10 & 1 & 0 & 0 & 0 & 1 & 2 & 0 & 1 & 1 & 0 & 0 & 0 & 0 & 0 & 0 & 0 & 1 & 1 & 5 & 1 & 1 & 0 & 0 & 0 & 1 & 0 \\
\hline I-11 & 2 & 1 & 1 & 0 & 1 & 2 & 2 & 2 & 2 & 0 & 0 & 1 & 0 & 0 & 0 & 0 & 1 & 1 & 1 & 2 & 0 & 0 & 0 & 0 & 0 & 0 \\
\hline I-12 & 2 & 2 & 2 & 0 & 2 & 2 & 2 & 1 & 3 & 1 & 1 & 1 & 0 & 4 & 0 & 0 & 1 & 1 & 1 & 0 & 0 & 0 & 0 & 1 & 1 & 1 \\
\hline I-13 & 3 & 1 & 2 & 0 & 1 & 2 & 1 & 1 & 0 & 1 & 2 & 0 & 0 & 1 & 0 & 0 & 1 & 1 & 1 & 5 & 0 & 0 & 0 & 0 & 0 & 1 \\
\hline
\end{tabular}

${ }^{€}$ Level of Use: 5 Very Often Used, 4 Often Used, 3 Occasionally Used, 2 Rarely Used, 1 Very Rarely Used, and 0 Never Used 
Table 18 (continued)

Weight Assigned to the Percentage of Strategies Used per Indicator

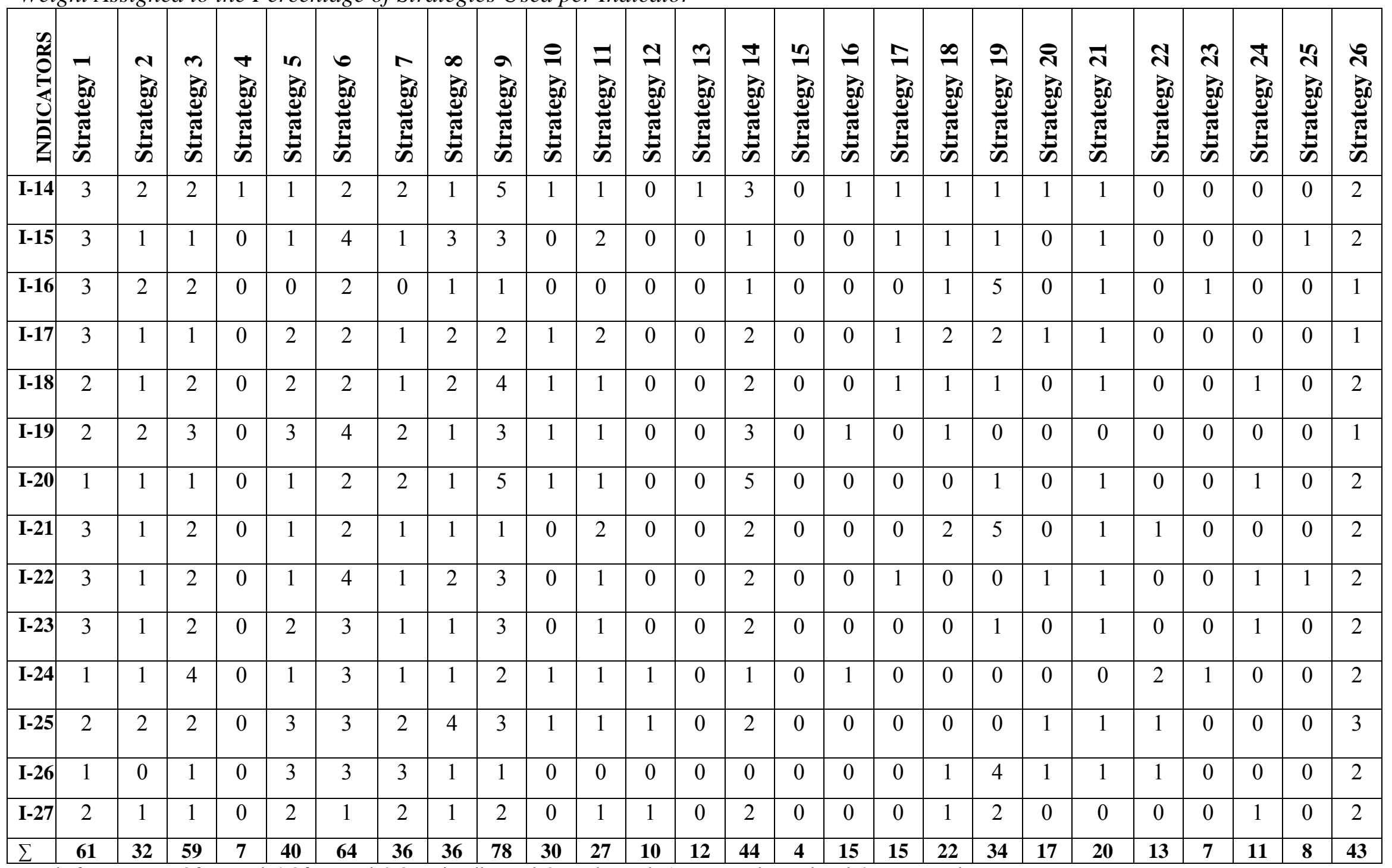
Level of Use: 5 Very Often Used, 4 Often Used, 3 Occasionally Used, 2 Rarely Used, 1 Very Rarely Used, and 0 Never Used

Quartiles: 78-60 Very Often Used, 59-41 Often Used, 40-22 Occasionally Used, and 21-4 Rarely Used. 
The analysis of the sum of the weights, as found in the final row of Table 18, according to the level of use attributed to the quartiles enabled the ranking of the strategies used across indicators. Using the ranges determined by the sum of the weights, strategies were grouped by their overall strength of use. Table 19 shows the rank of the strategies across the indicators and within the quartiles.

Table 19

Rank of Strategies Use Across Indicators and Within the Quartiles

\begin{tabular}{|c|c|c|}
\hline Quartiles & Strategies & $\begin{array}{c}\text { Sum of Weights } \\
\text { Totals }\end{array}$ \\
\hline \multirow{3}{*}{$\begin{array}{l}78-60- \\
\text { Very Often Used }\end{array}$} & Strategy 9: Appropriate Lesson/Learning Activity Development & 78 \\
\hline & Strategy 6: Presentation/Demo/Hands on & 64 \\
\hline & Strategy 1: Identifying/Defining appropriate use of IT & 61 \\
\hline \multirow{3}{*}{$\begin{array}{l}59-41- \\
\text { Often Used }\end{array}$} & Strategy 3: Evaluation/Critique/Assessment & 59 \\
\hline & Strategy 14: Problem- Based Learning/Project-Based Learning & 44 \\
\hline & Strategy 26: Lesson Implementation & 43 \\
\hline \multirow{8}{*}{$\begin{array}{l}40-22- \\
\text { Occasionally } \\
\text { Used }\end{array}$} & Strategy 5: Modeling & 40 \\
\hline & Strategy 7: Examples & 36 \\
\hline & Strategy 8: Mentoring/Consultation & 36 \\
\hline & Strategy 19: Telecollaboration & 34 \\
\hline & Strategy 2: Exemplars/Models/Experts & 32 \\
\hline & Strategy 10: Referencing Standards & 30 \\
\hline & Strategy 11: Team Work/Group Discussion/Peer Discussion & 27 \\
\hline & Strategy 18: Collaborative Learning & 22 \\
\hline \multirow{12}{*}{$\begin{array}{l}21-4- \\
\text { Rarely Used }\end{array}$} & Strategy 21: Technology Support Teams & 20 \\
\hline & Strategy 20: Made Technology Available & 17 \\
\hline & Strategy 16: Present/Develop/Use Rubrics & 15 \\
\hline & Strategy 17: Special Funding/Special Incentives & 15 \\
\hline & Strategy 22: Specific Assessment Tool & 13 \\
\hline & Strategy 13: Appropriate Lesson Development and Assessment & 12 \\
\hline & Strategy 24: Course/Curriculum Modification & 11 \\
\hline & Strategy 12: Grouping & 10 \\
\hline & Strategy 25: Resources Development & 8 \\
\hline & Strategy 4: Observation & 7 \\
\hline & Strategy 23: Faculty Research (Presentations/Conferences) & 7 \\
\hline & Strategy 15: Standards Specific Training & 4 \\
\hline
\end{tabular}

What is not shown in Table 19 are the specific indicators addressed by each of the strategies. Those can be found in Appendix M. The progression of analysis presented in Tables 11-19 led to the identification of those strategies, in rank order, that were successful in 
promoting high-level use of instructional technology in participants' teaching practice. The midpoint of the sum of weights was 41 , therefore any strategy whose sum of weight was equal to or above 41 was considered a top strategy used across indicators. Table 20 shows the top six strategies used by the majority of the participants to address different indicators.

Table 20

Rank of the Top Six Used Strategies Across Indicators

\begin{tabular}{lll}
\hline Rank & \multicolumn{1}{c}{ Strategy Code } & \multicolumn{1}{c}{ Description } \\
\hline $\mathbf{1}^{\text {st }}$ & Strategy 9 & Appropriate (Lesson/Learning Activity) Development \\
$\mathbf{2}^{\text {nd }}$ & Strategy 6 & Presentation/Demo/Hands on \\
$\mathbf{3}^{\text {rd }}$ & Strategy 1 & Identifying/Defining Appropriate Use of IT \\
$\mathbf{4}^{\text {th }}$ & Strategy 3 & Evaluation/Critique/Assessment \\
$\mathbf{5}^{\text {th }}$ & Strategy 14 & Problem-Based Learning/ Project-Based Learning \\
$\mathbf{6}^{\text {th }}$ & Strategy 26 & Lesson Implementation \\
\hline
\end{tabular}

The way the strategies were addressed in each indicator varies. This variation is more than can be presented in text. However, Appendix N provides the description of the use of the top six strategies for the indicators in which they were Very Often Used, Often Used and Occasionally Used. Appendix O shows the same level of details for those strategies whose the sum of weights fell within 40-22 (Occasionally Used). Appendix $\mathrm{N}$ and $\mathrm{O}$ were included in this study for professional development programs interested in the way the strategies were applied in the listed indicators. 
In summary data analyzed to answer Research Question 2 indicated that Strategies 9, 6, $1,3,14$ and 26 were the top six strategies used across indicators. Strategies $5,8,7,19,2,10,11$, and 18 were occasionally used across indicators but might be a possible consideration when planning a professional development program.

Of the 26 strategies used by participants to address the different indicators, 6 were used by a considerably high number of participants across indicators, 8 were occasionally used, and 12 were used sporadically and by a low number of participants to address some specific indicators. Therefore, these last 12 indicators are excluded from the list of strategies to consider when designing instructional technology professional development programs. 


\section{CHAPTER V: SUMMARY, DISCUSSION, AND RECOMMENDATIONS}

This chapter is divided in the following sections: (a) summary of research design, (b) discussion, (c) implications, and (d) recommendations for future research.

\section{Summary of Research Design}

The purpose of this study was to determine a set of common strategies employed by sustainable instructional technology professional development programs that are found to successfully promote educators' high-level use of technology in their teaching practice. Two questions guided this study: (a) Research Question 1: What do successful instructional technology professional development programs recognize as indicators of high-level use of technology?, and (b) Research Question 2: Which instructional technology professional development strategies successfully promote high-level use of instructional technology in participants' teaching practice?

The potential participants of this study were 179 directors or their designees, awardees of the PT3 1999 and 2000 implementation grants, from all over the United States and its territories. Out of these 179 potential participants, 70 (39.11\%) chose to participate in this study. An online questionnaire consisting of close-ended questions and open-ended questions were completed by the 70 participants during the summer of 2004.

The data from the close-ended questions of the questionnaire were analyzed using central tendency measures and were used to answer Research Question 1. For each close-ended question there was a corresponding open-ended question. The open-ended questions were analyzed using qualitative content analysis and the data coming from this section of the questionnaire were used to answer Research Question 2. 


\section{Discussion \\ Research Question 1}

Research Question 1 inquired about what indicators of high-level use of technology are recognized as part of instructional technology professional development programs. The overall results indicated that of the 27 indicators of high-level use of technology, 22 were recognized as part of the professional development programs participating in this study (see Table 10, p. 69).

The results from the analysis of the close-ended section of the Pedagogical Use of Instructional Technology in Teaching Questionnaire suggest that the majority of instructional technology programs participating in this study were successful in preparing their participants to address 22 of the 27 indicators of high-level use of technology. Table 21 presents the 22 indicators recognized by the professional development programs and their alignment with the NETS for teachers.

Table 21

Indicators Recognized by Professional Development Programs Aligned with NETS for Teachers

\begin{tabular}{lc}
\hline \multicolumn{1}{c}{ Indicators } & NETS for Teachers \\
Professional Development Programs Prepared Participants to: & \\
\hline $\begin{array}{l}\text { I-1. differentiate between appropriate and inappropriate uses of } \\
\text { technology for students' grade level and content area. }\end{array}$ & I, II, V,VI \\
\hline $\begin{array}{l}\text { I-2. design and implement learning activities that integrate technology } \\
\text { to support and expand students' critical thinking. }\end{array}$ & I, III \\
\hline $\begin{array}{l}\text { I-3. design and implement learning activities that integrate technology } \\
\text { to support and expand students' problem solving skills. }\end{array}$ & II, III,V \\
\hline $\begin{array}{l}\text { I-4. design and implement learner-centered lessons that are based on } \\
\text { the current best practices for integrating the learning of subject } \\
\text { matter and student technology standards. }\end{array}$ \\
\hline
\end{tabular}


Table 21 (continued)

Indicators Recognized by Professional Development Programs Aligned with NETS for Teachers

\begin{tabular}{|c|c|}
\hline $\begin{array}{c}\text { Indicators } \\
\text { Professional Development Programs Prepared Participants to: }\end{array}$ & NETS for Teachers \\
\hline $\begin{array}{l}\text { I-5. assess learner-centered lessons that are based on the current best } \\
\text { practices for integrating subject matter and student technology } \\
\text { standards. }\end{array}$ & $\mathrm{IV}, \mathrm{V}$ \\
\hline $\begin{array}{l}\text { I-6. design and implement student-centered, instructional materials } \\
\text { that take advantage of computers to engage students in their own } \\
\text { learning. }\end{array}$ & II, III \\
\hline
\end{tabular}

I-7. design and teach technology-enriched learning activities that II, III

connect content, state and national standards with student technology

standards.

I-8. design and teach technology-enriched learning activities that meet

II, III

the individual needs of students.
I-9. design an evaluation plan that applies multiple measures for $\quad$ IV
evaluating technology-based students’ products.
I-10. participate in online professional collaborations with peers and experts.

I-12. guide collaborative learning activities in which students use

III

technology resources to solve authentic problems in the subject area

(s).

I-13. arrange equitable access to appropriate technology resources

II, III, IV

that enable students to engage successfully in learning activities across

subject/content areas and grade levels.

\begin{tabular}{l}
$\begin{array}{l}\text { I-14. plan and implement technology-based learning activities that } \\
\text { promote student engagement in analysis, synthesis, interpretation, and } \\
\text { creation of original products. }\end{array}$ \\
$\begin{array}{l}\text { I-17. structure a learning environment where student collaboration is } \\
\text { the common practice when using technology. }\end{array}$ \\
$\begin{array}{l}\text { I-18. use students' interests, experiences when planning a variety of } \\
\text { computer-related activities. }\end{array}$ \\
\hline $\begin{array}{l}\text { I-19. implement project-based learning that emphasizes critical } \\
\text { content and higher-order thinking skills (e.g., analysis, synthesis, } \\
\text { evaluation) using the available computers. }\end{array}$ \\
\hline
\end{tabular}


Table 21 (continued)

Indicators Recognized by Professional Development Programs Aligned with NETS for Teachers

\begin{tabular}{|c|c|}
\hline $\begin{array}{l}\text { Indicators } \\
\text { Professional Development Programs Prepared Participants to: }\end{array}$ & NETS for Teachers \\
\hline $\begin{array}{l}\text { I-20. design and implement web-based projects that emphasize } \\
\text { complex thinking skill strategies such as problem-solving, scientific } \\
\text { inquiry, or decision-making. }\end{array}$ & III \\
\hline I-21. guide students' use of the Internet for collaboration with others. & II \\
\hline $\begin{array}{l}\text { I-22. use content-specific tools (e.g., software, simulation, web tools) to } \\
\text { support learning. }\end{array}$ & I, III \\
\hline I-23. use technology resources to facilitate knowledge construction. & I, III \\
\hline $\begin{array}{l}\text { I-24. apply technology tools and resources to collect, analyze, and } \\
\text { interpret data and report results. }\end{array}$ & IV \\
\hline $\begin{array}{l}\text { I-27. use technology in instruction to provide students with increased } \\
\text { levels of interactivity. }\end{array}$ & II, III \\
\hline
\end{tabular}

These 22 indicators addressed, to some extent, all the categories of high-level use of technology described in the literature review in this study. The majority of professional development programs reported to be successful in addressing Indicators 6,8 , and 14 . These results suggest that professional development programs are using technology to promote learnercentered instruction as called for in the literature (Moursund \& Bielefeldt, 1999; Roblyer \& Edwards, 2000; Salomon, 2002,Woodell \& Garofoli, 2003). The literature on high-level use of technology also indicates that professional development programs should prepare participants to use technology to create an atmosphere that favors the interpersonal relation among the learners through collaborative work (ISTE, 2000; Jonassen, 2000; McGrath, 2004; Roblyer \& Edwards, 2000; Salomon, 2002). This was accomplished by the majority of the participants reporting their success in addressing indicators 12,13, 17 and 21 that dealt with this issue. Furthermore, in addressing Indicators 2, 3, 18, 19, and 20 the professional development programs participating in this study covered the issues concerning high-order thinking skills as called for in this study's 
literature review (Jonassen, 2000, Trilling \& Hood, 1999). Finally, literature on high-level use of technology also advocates the need for preparing participants of professional development programs to use instructional technology as a means to establish contact with other teachers and experts in the field in order to exchange ideas and thoughts about teaching, and sharing their experiences (Earle, 2002; Harris, 1998; Keefe, 2003; Mckenzie, 2002; Tomei, 1997). The majority of the professional development programs participating in this study indicated success in dealing with this issue by addressing Indicators $1,4,5,7,10,22,23$, and 9 as components of their programs.

In conclusion, the results of this study show that 22 of the 27 indicators were recognized as major components of the majority of participating programs. The most critical issues found in the literature about high-level use of technology were well addressed by the participating programs. However, there were standards and indicators not addressed well by the programs participating in this study and therefore warrant explanation. Standards not addressed are shown in Table 22. The five indicators not addressed by the participants are shown in Table 23. 
Table 22

NETS for Teachers not Covered by Professional Development Programs

\section{Social, Ethical, Legal, and Human Issues}

Teachers understand the social, ethical, legal, and human issues surrounding the use of technology in PK-12 schools and apply that understanding in practice. Teachers:

B. apply technology resources to enable and empower learners with diverse backgrounds, characteristics, and abilities.

C. identify and use technology resources that affirm diversity.

E. facilitate equitable access to technology resources for all students.

Note: Reprinted with permission from National Educational Technology Standards for Teachers - Preparing Teachers to Use Technology, copyright (C) 2002, ISTE International Society for Technology in Education. All rights reserved. Permission does not constitute an endorsement by ISTE.

Table 23

Indicators of High-level Use of Technology not Addressed by Professional Development Programs

\begin{tabular}{ll}
$\begin{array}{c}\text { Indicator } \\
\text { Code }\end{array}$ & \multicolumn{1}{c}{ Our professional development program prepared participants to: } \\
\hline I-11 & $\begin{array}{l}\text { design and facilitate learning experiences that use assistive technologies to meet the special } \\
\text { physical needs of students. }\end{array}$ \\
\hline I-15 & facilitate students' use of technology that addresses their social needs and cultural identity. \\
\hline I-16 & $\begin{array}{l}\text { facilitate students' use of technology that promotes their interaction with the global } \\
\text { community. }\end{array}$ \\
\hline I-25 & $\begin{array}{l}\text { transfer what students' have learned in the classroom to real world situation when planning } \\
\text { the use of technology in the classroom(e.g., student-generated recycling program, student- } \\
\text { generated business). }\end{array}$ \\
\hline I-26 & $\begin{array}{l}\text { design online collaborative projects with other entities (e.g., schools, businesses, } \\
\text { organizations) to find solutions, make decisions, or seek a resolution to an issue of } \\
\text { importance to the students. }\end{array}$ \\
\hline
\end{tabular}

The literature on high-level use of technology indicates the need to prepare teachers to support different learning styles and needs, which also addresses students with limited English 
proficiency, gifted students, and students physically or mentally impaired (Boettcher, 2003;

Kimball, Cohen, Dimmick, \& Mills, 2003-2004; Thombs, 2003; Trilling \& Hood, 1999).

However, results indicate that the majority of instructional technology professional development programs did not prepare participants to address Indicator 11 (see Table 23).

Although professional development programs prepared participants to support learnercentered instruction and to use instructional technology to support different learning styles and needs, they did not prepare participants to use technology to support students who are physically or mentally impaired. The lack of success by professional development programs to support participants to prepare learning activities for special needs students might be due to the lack of training of teachers in general to address this population in a classroom context, even when technology is not involved. As indicated by some professional development programs, this was not a goal of their project, although they recognize its importance. As stated by one participant "we barely 'touched' on this objective; however we are now working more in this area." Participants in this study suggested that this was addressed only when having special education teachers as part of their professional development programs, as mentioned by a participant "the special education participants worked on developing lessons for special needs students."

The literature on high-level use of technology also suggests that teachers should use technology to help bridge cultural differences and increase the students' understanding of the issues concerning a multicultural society, encouraging and supporting the understanding of others beliefs and world perspectives (Jonassen, 2000; Trilling \& Hood, 1999). However, the majority of professional development programs participating in this study did not prepare their participants to address Indicator 15 and Indicator 16 (see Table 23). 
Although the professional development programs in this study reported to be successful in preparing their participants to use technology to facilitate the creation of a community of learners, they did not report success in preparing their participants to use technology to deal with cultural and multicultural issues. This result might be a reflection of the the feeling that this is an issue that comes naturally with instruction as mentioned by a participant that there is "no need to promote this, it comes naturally". Participants also reported that they had difficulties in addressing Indicator 16 due to technical difficulties imposed by online communication, "we attempted this but our server and pipeline abruptly became a huge issue."

It was also mentioned in the literature on high-level use of technology that teachers "must respect and encourage critical thinking and personal knowledge construction as meaningful goals using technology to motivate students to engage in thinking and learning activities that reflect students' realities" (Jonassen, 2000, p. 278). Professional development programs reported to be successful in preparing participants to encourage critical thinking and personal knowledge construction by supporting participants in preparing activities that reflect students' realities. However, the majority of professional development programs surveyed did not prepare their participants to address Indicator 25 (see Table 23).

Although professional development programs prepared participants to design activities that reflect their students' realities, they did not prepare participants to design activities that would support student transfer of what they have learned to their real lives. This is an issue that goes beyond the use of technology in education. Although educators advocate the connection between what students' learn and their realities, it is still an issue to lead students to transfer their content knowledge to their daily life knowledge. 
The literature review on high-level use of technology also mentioned the need for teachers to use technology as a facilitator of the human and social aspects of learning, creating an atmosphere that favors the interpersonal relation among the learners through collaborative work (Boettcher, 2003; Bull, Bull, Cochran, \& Bell, 2002; Cradler, 2003; Earle, 2002; Harris, 1998). However, the majority of the professional development programs did not address Indicator 26 (see Table 23).

Although professional development programs were successful in preparing participants to design project-based learning activities, they did not prepare participants to design online collaborative projects. As mentioned by some participants of this study, one of the reasons might be the lack of trust in technology to integrate an online project with another educational institute as a major part of a unit plan. Technology accessibility might also be an issue, for although one can guarantee one's own access to technology the online partner may have limitations to access technology. Also, that might not be one of the professional development's goals as stated by one of the participants: "not really of focus of our whole program, yet."

In conclusion, instructional professional development programs participating in this study reported preparing participants to address the majority of high-level use of technology indicators presented in this study. However, the professional development programs appeared to be weak on preparing participants to use technology to support social learning activities, learning activities that support diversity population, learning activities that support the learning of students with physical of mental needs, or learning activities that involve the global community. Furthermore, though professional development programs report success in preparing participants to design and implement project-based instruction, they fail to report the same success in helping participants transfer what they have learned in class to real world situation. 


\section{Research Question 2}

Research Question 2 inquired about the strategies that successfully promote high-level use of instructional technology in participants' teaching practice. The overall results indicated that the top six strategies used across indicators were:

- Strategy 9: Appropriate (Lesson/Learning Activity) Development

- Strategy 6: Presentation/Demo/Hands on

- $\quad$ Strategy 1: Identifying/Defining Appropriate Use of IT

- Strategy 3: Evaluation/Critique/Assessment

- $\quad$ Strategy 14: Problem-Based Learning/ Project-Based Learning

- $\quad$ Strategy 26: Lesson Implementation

The strategies that were occasionally used across indicators should be taken into consideration by professional development programs when preparing for their own programs for the following reasons: (a) the strategies that were occasionally used overall were the top strategies used to address particular indicators, and (b) they might have not made it to the top strategies for the way that the rater interpret and coding the participants responses:

- Strategy 5: Modeling

- $\quad$ Strategy 8: Mentoring/Consultation

- Strategy 7: Examples

- Strategy 19: Telecollaboration

- $\quad$ Strategy 2: Exemplars/Models/Experts

- $\quad$ Strategy 10: Referencing Standards

- $\quad$ Strategy 11: Team Work/Group Discussion/Peer Discussion

- Strategy 18: Collaborative Learning. 
All the most used strategies per indicator fell under the top six strategies and the occasionally used strategies used across indicators, with the exception of Strategies 16 and 20 that fell among the rarely used strategies across indicators but were the most often used strategies to address Indicator 9 and Indicator 13, respectively. Therefore, they might be considered when planning to address these specific indicators.

Of the 26 strategies used by participants to address the different indicators, 6 were used by a considerably high number of participants across indicators, 8 were occasionally used, and 12 were used sporadically and by a low number of participants to address some specific indicators, excluding them from the list of strategies to consider when designing instructional technology professional development programs.

Study results suggested that the top strategies used by professional development programs to promote high-level use of technology focused on the preparation of participants to explore, understand and support the use of technology in the classroom. All six top strategies were connected with preparing participants to develop appropriate lesson plans, units, or learning activities that integrate technology to support high-level thinking skills. Preparing participants to focus on the purpose of an activity and the reason for selecting certain instructional technology tools to enhance students' learning experience have been a priority for the majority of the professional development programs participating in this study. These findings substantiate the literature that advocates that it is the educators' responsibility to choose the instructional technology tool that will best promote students' learning based on their own beliefs and judgment of how learning should take place. The practice with instructional technologies and an understanding of their pedagogical applications are essential to the success of any professional 
development program (Harris, 1998; Mouza, 2002-2003; Roblyer \& Edwards, 2000; Tomei, 2002).

Findings from this study also suggest that professional development programs choose a number of different strategies to address the same goal. This is reflected in the results of the percentages of strategies used per indicator. None of the strategies were used $100 \%$, meaning that no one strategy was used by all the participants to address any given indicator. This result confirms Guskey's (2003) statement that the context where the professional development takes place strongly influences the characteristics that contribute to professional development's effectiveness. Therefore, to find diversity in the strategies used to address one common goal is to be expected since the professional development programs participating in this study differ in their context and the populations they addressed.

\section{Implications}

The findings from this study imply that instructional technology professional development programs should take the following into consideration when planning for professional development programs that focus in the high-level use of technology in participants' teaching:

First, professional development programs must make sure that the 22 indicators of highlevel use of technology recognized by the professional development programs in this study are addressed, since they cover to some extent all NETS for teachers and what the literature review on this study report about high-level use of technology. Nevertheless, in order to cover all the items in NETS for teachers and to address everything found in the literature about high-level use of technology the 27 indicators presented in this study should be addressed and be part of the professional development programs goals, not only the 22 recognized as part of the professional 
development programs in this study. Therefore, professional development programs should pay extra attention to assure that their professional development programs have activities that ensure the preparation of participants to use technology to support social learning activities, leaning activities that support diversity population, learning activities that support the learning of students with physical or mental needs, learning activities that involve the global community, and learning activities that support the transferring of what their students have learned in class to real world situation. A starting point is to see what kind of strategies the professional development programs that reported success in this area used to address the five indicators that were not part of the final list of high-level of use of technology recognized by the majority of professional development programs participating in this study.

Second, professional development programs should focus on the top six strategies listed in this study, when preparing participants to appropriately develop lesson plans, units, or learning activities that integrate technology to support high-level thinking skills. The top six strategies listed in this study support the preparation of participants to focus on the purpose of an activity and the reason for selecting certain instructional technology tools to enhance students' learning experience.

Finally, professional development programs should also consider those strategies that were "occasionally used" by the participants in this study as options to better address the context in which professional development programs take place. Furthermore, professional development programs looking to use the results of this study in future planning of their programs should look at individual indicators for those strategies most often used. For example, according to the results of this study Strategy 19: Telecollaboration was not among the top six strategies, however, for Indicator 10 this strategy had the highest percentage of use, indicating that the majority of the 
participants addressing Indicator 10 chose Strategy 19. Therefore, in addition to look at the top six strategies across indicators, professional development programs should look at the top strategies used per indicator to address the unique needs of the program.

In answering the research question, what are not addressed are the varieties of ways these strategies were implemented. Professional development programs reading these results should consider reviewing all the ways in which these strategies were used by referring to Appendix $\mathrm{N}$ and O. In summary, professional development programs should do the following when planning for their programs: (a) determine the goals of the professional development program, (b) match their goals with the high-level use of technology indicators presented in this study, (c) include the top six strategies - find the top strategies that are addressed by the indicators targeted by the program, and (d) find the best way to implement the strategies (see Appendix $\mathrm{N}$ and Appendix O). Following these steps should very well assure the success of professional development programs targeting high-level use of technology.

\section{Recommendations for Further Research}

The instructional professional development programs participating in this study had different specific goals, and focused on the needs of different populations. Some of them had interns as participants, others had faculty members, and still others had k-12 in-service teachers as their participants, while some had a mix of participants. The context in which they took place was unique for each of them. These factors might have influenced the results of this study. Therefore, further research should replicate this study focusing on instructional professional development programs that address a common target population.

This study focused on strategies used across indicators. While the results gave important insights into the kind of strategies being used to address high-level use of technology, further 
research focusing on the strategies per indicator would contribute to the overall understanding of ways to better promote the use of high-level use of technology in teaching.

Another area that warrants exploration is the indicators that the majority of participants reported as not being addressed by their professional development programs. Determining the reasons for failure to address these indicators can better help future professional development programs to include them as part of their programs.

The use of a questionnaire as the main means of data collection restricted the access to information. The inclusion of interviews as part of the research design could contribute significantly to the richness of the data collected.

There was much more to discuss from the open-ended data collected in this study. Some of the responses were very rich in detail, but taking all of it into consideration was beyond the scope of this study. Moreover, further validation of the instrument used is necessary. It is important to mention that this study's findings cannot be generalized due to the many constraints on this research design and the small population it addressed. It would be interesting if further study were conducted on the identification of indicators of high-level use of instructional technology in teaching, for which this research could serve as a source of comparison. 


\section{REFERENCES}

Barron, A. E., Kember, K., Harmes, C., \& Kalaydjian, K. (2003, Summer). Large-scale research study on technology in k-12 schools: Technology integration as it relates to the National Technology Standards. Journal of Research on Technology in Education, 35, 489-507.

Bielefeldt, T. (2002). Teacher outcomes: Improved technology skills. In J. Johnston \& L. T. Barker (Eds.), Assessing the impact of technology in teaching and learning. A sourcebook for evaluators (pp. 119-160). University of Michigan: Institute for Social Research. Retrieved January 30, 2004, from http://www.dlrn.org/star/sourcebook.html

Bober, M. J. (2002). Teacher outcomes: Changed pedagogy. In J. Johnston \& L. T. Barker (Eds.), Assessing the impact of technology in teaching and learning. A sourcebook for evaluators (pp. 87-118). University of Michigan: Institute for Social Research. Retrieved January 30, 2004, from http://www.dlrn.org/star/sourcebook.html

Boettcher, J. V. (2003). Designing for learning: The pursuit of well-structured content. Syllabus, $16,10-13$.

Bray, B. (1998). Ten steps for effective technology staff development. Retrieved May 01, 2003 from http://www.compstrategies.com/staffdevelopment/tensteps.html

Brush, T., Glazewski, K., Rutowski, K., Berg, K., Stromfors, C., Van-Nest, M. H., Stock, L., \& Sutton, J. (2003). Integrating technology in a field-based teacher training program: The PT3@ASU project.ETR\&D, 51, 57-71.

Bull, G., Bull, G., Cochran, P, \& Bell, R. (2002). Learner-based tools revisited: The enduring features of learner-based software: Logo and its successors. Learning \& Leading with Technology, 30, 10-17. 
Bybee, R. W. (2001). Effective professional development for technology teachers. The Technology Teacher, 61 (3), 26-29. Retrieved March 14, 2003 from WilsonWeb research database.

CEO Forum on Education \& Technology. (2000). Teacher preparation star chart: A self assessment tool for colleges of education. Retrieved May 25, 2003, from http://www.ceoforum.org/downloads/tpreport.pdf

Coughlin, E. C., \& Lemke, C. (1999). Professional competency continuum: Professional skills for the digital age classroom. Santa Monica, CA: Milken Family Foundation. Retrieved February 15, 2003, from http://www.mff.org/publications/publications.taf?page=159

Cox, J. (1996). Your opinion, please: How to build the best questionnaires in the field of education. Thousands Oaks, CA: Corwin Press, Inc.

Cradler, J. (2003). Technology's impact on teaching and learning. Learning \& Leading with Technology, 30, 54-57.

Cradler, J., Freeman, M., Cradler, R., \& McNabb, M. (2002, September). Research implications for preparing teachers to use technology. Leading \& Learning with Technology, 30, 5054.

Crawford, C. (2003). Web-enhancing university coursework: An innovative professional development model to support a step-by-step approach towards web-enhancing courses and empowering instructors. International Journal on E-Learning, 2 (1), 5-13.

Driscoll, M. (1998). Web-based training: Using technology to design adult learning experience. San Francisco, CA: Jossey-Bass/Pfeiffer.

Driscoll, M. P. (2000). Psychology of learning for instruction ( $2^{\text {nd }}$ ed.). Needam Heights, MA: Allyn \& Bacon. 
Earle, R. S. (2002, January-February). The integration of instructional technology into public education: Promises and challenges. Educational Technology, 42, 5-13.

Feist, L. (2003, June). Removing barriers to professional development. T.H.E. Journal, 31, 3036.

Fink, A, \& Kosecoff, J. B. (1985). How to conduct surveys: A step-by-step guide. London, England: SAGE Publications, Ltd.

Fink, A. (1995a). The survey handbook. Thousands Oaks, CA: Sage Publications, Inc.

Fink, A. (1995b). How to ask survey questions. Thousands Oaks, CA: Sage Publications, Inc.

Fink, A. (1995c). How to design surveys. Thousands Oaks, CA: Sage Publications, Inc.

Firdyiwek, Y. (1999, January-February). Web-based courseware tools: Where is the pedagogy? Educational Technology, 39, 29-35.

Fowler, F. J. (1995). Improving survey questions: Design and evaluation. Thousands Oaks, CA: Sage Publications, Inc.

Garet, M. S., Porter, A. C., Desimone, L., Birman, B. F., \& Yoon, K. S. (2001). What makes professional development effective? Results from a national sample of teachers. American Educational Research Journal, 38, 915-945.

Gonzales, C., Pickett, L., Hupert, N., \& Martin, W. (2002). The regional educational technology assistance program: Its effects on teaching practice. Journal of Research on Technology in Education, 35, 1-18. Retrieved July 07, 2003 from Wilson Web research database.

Goodale, C., Carbonaro, M., \& Snart, F. (2003). Faculty of education staff development: Support of tomorrow's teachers. Paper presented on SITE conference 2003. Retrieved September 01, 2003, from http://www.aace.org/conf/site/pt3/paper_3008_1038.pdf 
Grant, C. M. (1996). Professional development in a technological age: New definitions, old challenges, new resources. Technology Infusion and School Change: Perspective and Practices. Retrieved May 15, 2003, from http://ra.terc.edu/publications/TERC pubs/techinfusion/prof dev/prof dev frame.html

Groves, M. M., \& Zemel, P. C. (2000). Instructional technology adoption in higher education: An action research case study. International Journal of Instructional Media, 27, 57-65. Retrieved October 7, 2002 from EbscoHost Research Databases.

Guskey, T. R. (2000). Evaluating professional development. Thousands Oaks, CA: Corwin Press, Inc.

Guskey, T. R. (2002). Does it make a difference? Evaluating professional development. Educational Leadership, 56, 45-51.

Guskey, T. R. (2003). Analyzing lists of the characteristics of effective professional development to promote visionary leadership. NASSP Bulletin, 87, 38-54.

Harris, J. (1998). Virtual Architecture: Designing and directing curriculum-based telecomputing. Eugene, OR: International Society for Technology in Education (ISTE).

Harris, J., \& Grandgenett, N. (2002, November). Teachers' authentic e-learning. Learning \& Leading with Technology, 30 (3), 54-59.

Hittleman, D. R, \& Simon, A. J. (2002). Interpreting educational research $\left(3^{\text {rd }}\right.$ ed.). Upper Saddle River, NJ: Merrill Prentice Hall.

Holland, P. E. (2001). Professional development in technology: Catalyst for school reform. Journal of Technology and Teacher Education, 9 (2), 245-267.

International Society for Technology in Education. (2000). National educational technology standards for teachers: Preparing teachers to use technology. (Section 1). Retrieved 
December 09, 2002, from http://cnets.iste.org/teachers/pdf/Sec 1-

\section{1_Establishing_NETST.pdf}

International Society for Technology in Education. (2003a). National educational technology standards (NETS) and the states. Retrieved January 31, 2004, from http://cnets.iste.org/docs/States_using_NETS.pdf

International Society for Technology in Education. (2003b). National educational technology standards for teachers: Resources for assessment. Eugene, OR: Author.

Jonassen, D. H. (2000). Computers as mindtools for schools: Engaging critical thinking (2 ${ }^{\text {nd }}$ ed.). Upper Saddle River, NJ: Prentice Hall.

Keefe, T. J. (2003). Using technology to enhance a course: The importance of interaction. Educause Quarterly, 26, 24-34.

Kimball, W. H., Cohen, L. G., Dimmick, D., \& Mills, R. (2003-2004). No special equipment required. Learning \& Leading with Technology, 31, 12-15.

Kleiman, G., \& Johnson, K. (1998, September). Professional development from reports to reality. EdTech Leaders Online. Retrieved May 03, 2003, from http://www.edtechleaders.org/Resources/articles/reality1.htm

Knowles, M. S., Holton, E. F., \& Swanson, R. A. (1998). The adult learner: The definitive classic in adult education and human resource development ( $5^{\text {th }}$ ed.). Houston, TX: Gulf Publishing Company.

Lam, Y. (2000). Technophilia vs. technophobia. A preliminary look at why second language teachers do not use technology in their classroom. Canadian Modern Language Review, $56,389-420$. 
McGrath, D. (2004). Strengthening collaborative work: Go beyond the obvious with tools for technology enhanced collaboration. Learning \& Leading with Technology, 31, 30-33.

Mckenzie, J. (1998). Professional development that works. eSchool News. Retrieved May 01, 2003, from http://staffdevelop.org/secrets.html

Mckenzie, J. (2001). How teachers learn technology best. The Educational Technology Journal, 10, 1-13. Retrieved October 07, 2003 from EbscoHost Research Databases.

Mckenzie, J. (2002). Beyond toolishness: The best way for teachers to learn and put new technologies to good use. Multimedia Schools, 9, 34-39.

Merriam-Webster. (1995). Merriam-Webster's Collegiate Dictionary (10 ${ }^{\text {th }}$ ed.). Springfied, MA: Merriam-Webster.

Miles, M. B., \& Huberman, A. M. (1994). An expanded sourcebook: Qualitative data analysis ( $2^{\text {nd }}$ ed.). Thousands Oaks, London: Sage Publications.

Moersch, C. (1995). Levels of technology implementation (LoTi): A framework for measuring classroom technology use. Learning \& Leading with Technology, 23(3), 40-42.

Moersch, C. (2002). Measurers of success: Six instruments to assess teacher's use of technology. Learning \& Leading with Technology, 30 (2), 10-14.

Moersch, C. M. (1996-1997). Computer efficiency: Measuring the instructional use of technology. Learning \& Leading with Technology, 24 (4), 52-56.

Morse, J. M., \& Richards, L. (2002). Readme first for a users's guide to qualitative methods. Thousands Oaks, CA: Sage Publications, Inc

Moursund, D., \& Bielefeldt, T. (1999). Will new teachers be prepared to teach in a digital age? A national survey on information technology in teacher education. Santa Monica, CA: 
Milken Family Foundation. Retrieved January 31, 2004, from

http://www.mff.org/publications/publications.taf?page $=154$

Mouza, C. (2002-2003, Winter). Learning to teach with new technology: Implications for professional development. Journal of Research on Technology in Education, 35, 272289.

National Conference of State Legislatures. (2002). Professional development. Retrieved May 06, 2003, from http://www.ncsl.org/programs/educ/TPRoDev.htm.

National Foundation for the Improvement of Education. (2000). Connecting the bits: A reference for using technology in teaching and learning in $k-12$ schools. Washington, DC.

Retrieved June 19, 2003, from http://www.nfie.org/publications/connecting.htm

North Central Regional Education Laboratory. (2003). Educator proficiency. Retrieved May 01, 2003, from http://www.ncrel.org/engauge/framewk/pro/proin.htm

Office of Technology Assessment, U.S. Congress. (1995). Teachers and technology: Making the connection. OTA-HER-616. Washington, DC: U.S. Government Printing Office.

Onwuegbuzie, A. J., \& Teddlie, C. (2003). A framework for analyzing data in mixed methods research. In A. Tashakkori \& C. Teddlie (Eds.), Handbook of mixed methods in social \& behavioral research (pp. 351-383). Thousands Oaks, CA: Sage Publications, Inc.

Patten, M. L. (2001). Questionnaire research: A practical guide ( $2^{\text {nd }}$ ed.). Los Angeles, CA: Pyrczak Publishing.

Patton, M. Q. (2002). Qualitative research and evaluation methods ( $3^{\text {rd }}$ ed.). Thousand Oaks, CA: Sage Publications, Inc.

Poplin, C. J. (2003, June). Models of professional development. T.H.E Journal, 31, 38-41. 
Preparing Tomorrow's Teacher to Use Technology, U.S. Department of Education. (1998). Capacity Building, Implementation, Catalyst Grants: Guidelines for applying to 19992002 Grants.

Preparing Tomorrow's Teacher to Use Technology. (2002). Faculty development: Stories \& strategies. Retrieved January 25, 2003, from http://www.pt3.org/stories/faculty.html

Roblyer, M. D. (2003). Gettting our NETS worth: The role of ISTE's national educational technology standards. Learning \& Leading with Technology, 30, 6-13.

Roblyer, M. D., \& Edwards, J. (2000). Integrating educational technology into teaching (2 ${ }^{\text {nd }}$ ed.). Upper Saddle River, NJ: Prentice-Hall, Inc.

Salomon, G. (2002, March-April). Technology and pedagogy: Why don't we see the promised revolution? Educational Technology, 42, 71-75.

Salpeter, J. (2003, August). Professional development: $21^{\text {st }}$ century models. Technology \& Learning, 24, 34-50.

Schrum, L. (1999). Technology professional development for teachers. ETR\&D, 47 (4), 83-90.

Seels, B., Campbell, S., \& Talsma, V. (2003). Supporting excellence in technology through communities of learners. ETR\&D, 51, 91-104.

Shambaugh, R. N., \& Magliaro, S. G. (1997). Mastering the possibilities: a process approach to instructional design. Needham Heights, MA: Allyn and Bacon.

Shannon, D. M, \& Bradshaw, C. C. (2002). A comparison of response rate, response time, and costs of mail and electronic surveys. The Journal of Experimental Education, 70 (2), 179192. 
Sparks, D. (2002). Designing powerful professional development for teachers and principals. National Staff Development Council. Retrieved June 7, 2003, from http://www.nsdc.org/sparksbook.html

Stemler, S. (2001). An overview of content analysis. Practical Assessment, Research \& Evaluation, 7 (17). Retrieved March, 15, 2004, from http://PAREonline.net/getvn.asp?v=7\&n=17.

Thombs, M. M. (2003). Accessible web pages: Advice for educators. Syllabus, 16, $26-28$.

Tomei, L. A. (1997). Instructional technology: Pedagogy for the future. T.H.E Journal, 25, 5659. Retrieved July 07, 2003, from Academic Search Elite Research Database.

Tomei, L. A. (2002). The technology facade: Overcoming barriers to effective instructional technology. Boston, MA: Allyn \& Bacon.

Tomei, L. A. (2003). The taxonomy for the technology domain. Retrieved June 02, 2004, from http://www.duq.edu/\%7Etomei/taxonomy/

Trilling, B., \& Hood, P. (1999, May-June). Learning technology, and education reform in the knowledge age or "we're wired, webbed, and windowed, now what?" Educational Technology, 39, 5-13.

U.S. Department of Education, No Child Left Behind. (2000). The facts about...21 $1^{\text {st }}$ century technology. Retrieved May 20, 2003, from http://www.nclb.gov/start/facts/21centtech.html

U.S. Department of Education. (2000). Building bridges: The mission \& principles of professional development. Retrieved May 01, 2003, from http://www.ed.gov/G2K/bridge.html 
U.S. Department of Education. (2001). The 1999-2000 annual performance reports for preparing tomorrow's teacher to use technology. Retrieved April 10, 2003, from http://www.ed.gov/offices/OUS/PES/higher/apr analysis/highlights.html

Waltz, C. F., \& Bausell, R. B. (1983). Nursing research: Design, statistics and computer analysis ( $2^{\text {nd }}$ ed.). Philadelphia, PA: Davis Company.

Web-Based Education Commission. (2000). Report of the web-based education commission to the president of the United States: The power of the Internet for learning moving from promise to practice. Washington, DC: Retrieved May 28, 2003, from $\underline{\text { http://interact.hpcnet.org/webcommission/index.htm }}$

White, K., Weigandt, C., \& Wells, J. (2002, March). Trek 21 PT3 project: Evolution of professional development. Paper presented at the Society for Information Technology \& Teacher Education (SITE) Conference, Nashville, TN.

Whitfield, C. M., \& Latimer, B. T. (2003). A model for technology integration: C.R.E.A.T.E for Mississippi’s school mentor program. Leading \& Learning with Technology, 30 (4), 5255.

Woodell, J., \& Garofoli, E. (2003). Faculty development and the diffusion of innovations. Syllabus, 16, 15-17.

Yaghmaie, F. (2003). Content validity and its estimation. Journal of Medical Education. Retrieved March 09, 2004, from http://www.sbmu.ac.ir/Journal/MedEdu/jme7nol/Content $\% 20$ validity $\% 20$ and $\% 20$ its $\% 20$ estimation.htm 
APPENDICES 
APPENDIX A

\section{QUESTIONNAIRE'S ITEMS AND INSTRUMENS USED TO CREATE THEM}




\begin{tabular}{|c|c|c|c|c|c|c|c|c|c|c|}
\hline \multirow[b]{2}{*}{ QUESTIONNAIRE ITEMS } & \multicolumn{4}{|c|}{$\begin{array}{l}\text { NETS for Teachers } \\
\text { Profiles }\end{array}$} & \multicolumn{3}{|c|}{ LoTi } & \multicolumn{2}{|c|}{ PCC } & \multirow[b]{2}{*}{$\begin{array}{l}\text { NETS for } \\
\text { Teachers }\end{array}$} \\
\hline & $\begin{array}{l}\bar{\pi} \\
\overline{0} \\
\stackrel{0}{0} \\
0\end{array}$ & 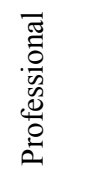 & 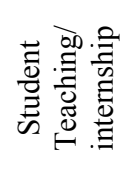 & 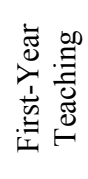 & 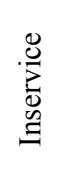 & 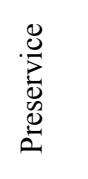 & 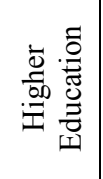 & 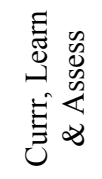 & 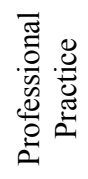 & \\
\hline $\begin{array}{l}\text { differentiate between appropriate and inappropriate uses of } \\
\text { technology for students' grade level and content area }\end{array}$ & 12 & 2 & & & 15 & & 15 & 3 & & $\mathrm{I}, \mathrm{II}, \mathrm{V}, \mathrm{VI}$ \\
\hline $\begin{array}{l}\text { 2. design and implement learning activities that integrate } \\
\text { technology to support and expand students' critical } \\
\text { thinking. }\end{array}$ & 5 & & & & & 46 & & & & I, III \\
\hline $\begin{array}{l}\text { 3. design and implement learning activities that integrate } \\
\text { technology to support and expand students' problem solving } \\
\text { skills. }\end{array}$ & 5 & & 17 & & & 46 & & & & I, III \\
\hline $\begin{array}{l}\text { 4. design and implement learner-centered lessons that are } \\
\text { based on the current best practices for integrating the } \\
\text { learning of subject matter and student technology standards }\end{array}$ & & 8 & 7 & 4 & & & & & & II, III,V \\
\hline $\begin{array}{l}\text { 5. assess learner-centered lessons that are based on the current } \\
\text { best practices for integrating subject matter and student } \\
\text { technology standards. }\end{array}$ & & & 7 & & & & & & & $\mathrm{IV}, \mathrm{V}$ \\
\hline $\begin{array}{l}\text { 6. design and implement student-centered, instructional } \\
\text { materials that take advantage of computers to engage } \\
\text { students in their own learning. }\end{array}$ & & & & & & 34 & & & & II, III \\
\hline $\begin{array}{l}\text { 7. design and teach technology-enriched learning activities that } \\
\text { connect content, state and national standards with student } \\
\text { technology standards. }\end{array}$ & & 7 & 6 & & & & & 2 & & II, III \\
\hline $\begin{array}{l}\text { 8. design and teach technology-enriched learning activities that } \\
\text { meet the individual needs of students. }\end{array}$ & & 6,7 & & & & & & & & II, III \\
\hline $\begin{array}{l}\text { 9. design an evaluation plan that applies multiple measures for } \\
\text { evaluating technology-based students' products. }\end{array}$ & & 12 & 9 & & & & & 15 & & IV \\
\hline $\begin{array}{l}\text { 10. participate in online professional collaborations with peers } \\
\text { and experts. }\end{array}$ & 13 & 18 & 15 & 17 & & & & & 3 & $\mathrm{~V}$ \\
\hline
\end{tabular}




\begin{tabular}{|c|c|c|c|c|c|c|c|c|c|c|}
\hline \multirow[b]{2}{*}{ QUESTIONNAIRE ITEMS } & \multicolumn{4}{|c|}{$\begin{array}{l}\text { NETS for Teachers } \\
\text { Profiles }\end{array}$} & \multicolumn{3}{|c|}{ LoTi } & \multicolumn{2}{|c|}{ PCC } & \multirow[b]{2}{*}{$\begin{array}{l}\text { NETS for } \\
\text { Teachers }\end{array}$} \\
\hline & $\begin{array}{l}\bar{\pi} \\
\stackrel{0}{0} \\
0 \\
0\end{array}$ & 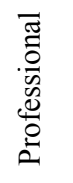 & 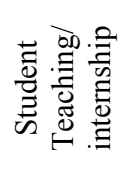 & 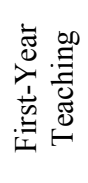 & 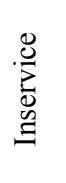 & 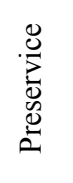 & 离 & 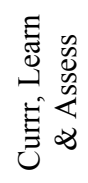 & 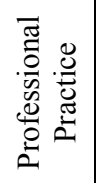 & \\
\hline $\begin{array}{l}\text { 11. design and facilitate learning experiences that use assistive } \\
\text { technologies to meet the special physical needs of students. }\end{array}$ & & 24 & 5 & & & & & & & II, III, VI \\
\hline $\begin{array}{l}\text { 12. guide collaborative learning activities in which students use } \\
\text { technology resources to solve authentic problems in the } \\
\text { subject area (s). }\end{array}$ & & & 8 & & & & & & & III \\
\hline $\begin{array}{l}\text { 13. arrange equitable access to appropriate technology resources } \\
\text { that enable students to engage successfully in learning } \\
\text { activities across subject/content areas and grade levels. }\end{array}$ & & & & 3 & & & & & & II, III, IV \\
\hline $\begin{array}{l}\text { 14. plan and implement technology-based learning activities that } \\
\text { promote student engagement in analysis, synthesis, } \\
\text { interpretation, and creation of original products. }\end{array}$ & & & & 5 & & & & & & II, III \\
\hline $\begin{array}{l}\text { 15. facilitate students' use of technology that addresses their } \\
\text { social needs and cultural identity. }\end{array}$ & 14 & & & 12 & & & & & & III,VI \\
\hline $\begin{array}{l}\text { 16. facilitate students' use of technology that promotes their } \\
\text { interaction with the global community. }\end{array}$ & & & & 12 & & & & & & III,VI \\
\hline $\begin{array}{l}\text { 17. structure a learning environment where student collaboration } \\
\text { is the common practice when using technology. }\end{array}$ & 15 & & & & & & & 4 & & $\mathrm{I}, \mathrm{VI}$ \\
\hline $\begin{array}{l}\text { 18. use students' interests, experiences when planning a variety } \\
\text { of computer-related activities. }\end{array}$ & 9 & & & & 33 & 35 & 34 & & & I, II, III \\
\hline $\begin{array}{l}\text { 19. implement project-based learning that emphasizes critical } \\
\text { content and higher-order thinking skills (e.g., analysis, } \\
\text { synthesis, evaluation) using the available computers. }\end{array}$ & & 1 & & & 8 & 8 & & & 10 & III \\
\hline $\begin{array}{l}\text { 20. design and implement web-based projects that emphasize } \\
\text { complex thinking skill strategies such as problem-solving, } \\
\text { scientific inquiry, or decision-making. }\end{array}$ & & & & & 5 & 5 & & & & III \\
\hline
\end{tabular}


Questionnaire's Items and Instruments Used to Create Them (continued)

\begin{tabular}{|c|c|c|c|c|c|c|c|c|c|c|}
\hline \multirow[b]{2}{*}{ QUESTIONNAIRE ITEMS } & \multicolumn{4}{|c|}{$\begin{array}{l}\text { NETS for Teachers } \\
\text { Profiles } \\
\end{array}$} & \multicolumn{3}{|c|}{ LoTi } & \multicolumn{2}{|c|}{ PCC } & \multirow[b]{2}{*}{$\begin{array}{l}\text { NETS for } \\
\text { Teachers }\end{array}$} \\
\hline & $\begin{array}{l}\bar{\pi} \\
\overline{0} \\
0 \\
0\end{array}$ & 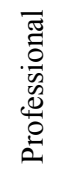 & 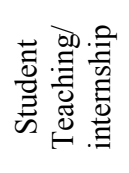 & 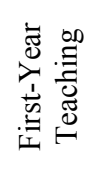 & 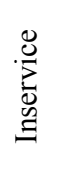 & $\begin{array}{l}.00 \\
\frac{0}{0} \\
0 \\
0 \\
0 \\
0\end{array}$ & 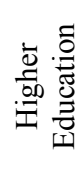 & 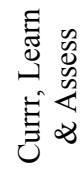 & 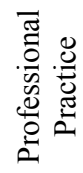 & \\
\hline $\begin{array}{l}\text { 21. guide students' use of the Internet for collaboration with } \\
\text { others. }\end{array}$ & & & & & 21 & & 22 & 11 & & II \\
\hline $\begin{array}{l}\text { 22. use content-specific tools (e.g., software, simulation, web } \\
\text { tools) to support learning. }\end{array}$ & 4 & & & & & & & & & I, III \\
\hline 23. use technology resources to facilitate knowledge construction. & 5 & & & & & & & 7 & & I, III \\
\hline $\begin{array}{l}\text { 24. apply technology tools and resources to collect, analyze, and } \\
\text { interpret data and report results. }\end{array}$ & & & 12 & & & & & & 5 & IV \\
\hline $\begin{array}{l}\text { 25. transfer what students' have learned in the classroom to real } \\
\text { world situation when planning the use of technology in the } \\
\text { classroom(e.g., student-generated recycling program, } \\
\text { student-generated business). }\end{array}$ & & & & & 36 & & 33 & 5 & & II, III \\
\hline $\begin{array}{l}\text { 26. design online collaborative projects with other entities (e.g., } \\
\text { schools, businesses, organizations) to find solutions, make } \\
\text { decisions, or seek a resolution to an issue of importance to the } \\
\text { students. }\end{array}$ & & & & & & 22 & 21 & & & II, III \\
\hline $\begin{array}{l}\text { 27. use technology in instruction to provide students with } \\
\text { increased levels of interactivity. }\end{array}$ & & & & & & & & 6 & & II, III \\
\hline
\end{tabular}


APPENDIX B

PEDAGOGICAL USE OF INSTRUCTIONAL TECHNOLOGY IN TEACHING

QUESTIONNAIRE 


\section{Pedagogical Use of Instructional Technology in Teaching Questionnaire}

\section{DIRECTIONS:}

This questionnaire takes about 30 minutes to complete. It focuses exclusively on the instructional uses of the computer-based technology. It presents you with 27 statements reflecting ways in which a PT3 professional development program may have prepared participants to use ITs as part of their practice.

For each statement you are being asked to indicate the degree to which the statement reflects your way of preparing participants to use IT. Choose Strongly Agree or Agree if your program prepared the participants to accomplish what is indicated in the statement. Choose Disagree or Strongly Disagree if your program did not prepare the participants to accomplish what is indicated in the statement. Choose Not Applied in my Professional Development if the statement was not part of the program's goals and/or objectives.

For those statements you answer Strongly Agree or Agree, use the text box beside the question to briefly describe the strategy(ies) your program used to achieve the statement. Otherwise, write N/A in the textbox, or leave it blank skipping to the next question. After completing all the survey click on the Submit button at the bottom of the page. Below is an example of a Strongly Agree response.

\section{EXAMPLE:}

Our professional development program prepared participants to:

0. differentiate between appropriate and inappropriate uses of technology for students' grade level and content area.

\section{Strongly Agree (Provide Strategies)}

C Agree (Provide Strategies)

C Disagree

C Strongly Disagree

C Not Applied in my Professional Development 0.a. If you Agreed or Strongly Agreed with this statement please list the strategy(ies) you used to accomplish it.

a) Participants from the same subject area and grade level were asked to develop a collaborative lesson using technology tools

b) Examples of lessons that successfully used instructional technology to promote learning in their content area were provided to them

c) Their lessons were evaluated for effectiveness and suggestions were made by experts in their area

\section{CLICK TO BEGIN QUESTIONNAIRE}

\section{Pedagogical Use of I nstructional Technology in Teaching Questionnaire}

Take the time you need to complete the questionnaire. You will not be timed out. However, you must complete it once you start it. You cannot close it and then come back.

\section{Enter your e-mail:}




\begin{tabular}{|c|c|}
\hline $\begin{array}{l}\text { Our professional development program prepared participants to: } \\
\text { 1. differentiate between appropriate and inappropriate uses of } \\
\text { technology for students' grade level and content area. } \\
\text { O Strongly Agree (Provide Stratchies) } \\
\text { Agree (Prowide Strategia) } \\
\text { O Disagree } \\
\text { O Strongly Disagree } \\
\text { Not Applied in my Professional Development }\end{array}$ & $\begin{array}{l}\text { 1.a. If you Agreed or Strongly Agreed with this statement please list } \\
\text { the strategy(ies) you used to accomplish it. }\end{array}$ \\
\hline $\begin{array}{l}\text { Our professional development program prepared participants tos } \\
\text { 2. design and implement learning activities that integrate } \\
\text { technology to support and expand students' critical thinking. } \\
\text { O Strongly Agree (Provide Srutegies) } \\
\text { Agree (Pravide Strategies) } \\
\text { O Disagree } \\
\text { Strongly Disagree } \\
\text { Not Applied in my Professional Development }\end{array}$ & $\begin{array}{l}\text { 2.a. If you Agreed or Strongly Agreed with this statement please list } \\
\text { the strategy(ies) you used to accomplish it. }\end{array}$ \\
\hline $\begin{array}{l}\text { Our professional development program prepared participants to: } \\
\text { 3. design and implement learning activities that integrate } \\
\text { technology to support and expand students' problem solving skills. } \\
\text { O Strongly Agree (Provide Strategies) } \\
\text { O Agree (Prowide Strateglas) } \\
\text { O Disagree } \\
\text { O Strongly Disagree } \\
\text { O Not Applied in my Professional Development }\end{array}$ & $\begin{array}{l}\text { 3.a. If you Agreed or Strongly Agreed with this statement please list } \\
\text { the strategy(ies) you used to accomplish it. }\end{array}$ \\
\hline $\begin{array}{l}\text { Our professional development program prepared participants to: } \\
\text { 4. design and implement learner-centered lessons that are based on } \\
\text { the current best practices for integrating the learning of subject } \\
\text { matter and student technology standards } \\
\text { O Strongly Agree (Provide Sratgies) } \\
\text { O Agree (Provide Stratigles) } \\
\text { Disagree } \\
\text { Strongly Disagree } \\
\text { O Not Applied in my Professional Development }\end{array}$ & $\begin{array}{l}\text { 4.a. If you Agreed or Strongly Agreed with this statement please list } \\
\text { the strategy(ies) you used to accomplish it. }\end{array}$ \\
\hline
\end{tabular}




\begin{tabular}{|c|c|}
\hline $\begin{array}{l}\text { Our professional development program prepared participants to: } \\
\text { 5. assess learner-centered lessons that are based on the current best } \\
\text { practices for integrating subject matter and student technology } \\
\text { standards. } \\
\text { Strongly Agree (Pravide Strategles) } \\
\text { Agree (Provide Stratcela) } \\
\text { Disagree } \\
\text { Strongly Disagree } \\
\text { Not Applied in my Professional Development }\end{array}$ & $\begin{array}{l}\text { 5.a. If you Agreed or Strongly Agreed with this statement please list } \\
\text { the strategy(ies) you used to accomplish it. }\end{array}$ \\
\hline $\begin{array}{l}\text { Our professional development program prepared participants to: } \\
\text { 6. design and implement student-centered, instructional materials } \\
\text { that take advantage of computers to engage students in their own } \\
\text { learning. } \\
\text { Strongly Agree (Prowide Strategies) } \\
\text { Agree (Provide Stratgia) } \\
\text { Disagree } \\
\text { Strongly Disagree } \\
\text { Not Applied in my Professional Development }\end{array}$ & $\begin{array}{l}\text { 6.a. If you Agreed or Strongly Agreed with this statement please list } \\
\text { the strategy(ies) you used to accomplish it. }\end{array}$ \\
\hline $\begin{array}{l}\text { Our professional development program prepared participants to: } \\
\text { 7. design and teach technology-enriched learning activities that } \\
\text { connect content, state and national standards with student } \\
\text { technology standards. } \\
\text { Strongly Agree (Provide Strategies) } \\
\text { Agree (Provide Strategle) } \\
\text { Disagree } \\
\text { Strongly Disagree } \\
\text { Not Applied in my Professional Development }\end{array}$ & $\begin{array}{l}\text { 7.a. If you Agreed or Strongly Agreed with this statement please list } \\
\text { the strategy(ies) you used to accomplish it. }\end{array}$ \\
\hline $\begin{array}{l}\text { Our professional development program prepared participants to: } \\
\text { 8. design and teach technology-enriched learning activities that } \\
\text { meet the individual needs of students. } \\
\text { Strongly Agree (Prowde Strategies) } \\
\text { Agree (Provide Stratgia) } \\
\text { Disagree } \\
\text { Strongly Disagree } \\
\text { Not Applied in my Professional Development }\end{array}$ & $\begin{array}{l}\text { 8.a. If you Agreed or Strongly Agreed with this statement please list } \\
\text { the strategy(ies) you used to accomplish it. }\end{array}$ \\
\hline
\end{tabular}




\begin{tabular}{|c|c|}
\hline $\begin{array}{l}\text { Our professional development program prepared participants to: } \\
\text { 9. design an evaluation plan that applies multiple measures for } \\
\text { evaluating technology-based students' products. } \\
\text { O Strongly Agree (Provide Strutegia) } \\
\text { O Agree (Provide Strategia) } \\
\text { O Disagree } \\
\text { O Strongly Disagree } \\
\text { O Not Applied in my Professional Development }\end{array}$ & $\begin{array}{l}\text { 9.a. If you Agreed or Strongly Agreed with this statement please list } \\
\text { the strategy(ies) you used to accomplish it. }\end{array}$ \\
\hline $\begin{array}{l}\text { Our professional development program prepared participants to: } \\
\text { 10. participate in online professional collaborations with peers and } \\
\text { experts. } \\
\text { O Strongly Agree (Provide Strategia) } \\
\text { O Agree (Provide Stratgia) } \\
\text { O Disagree } \\
\text { O Strongly Disagree } \\
\text { O Not Applied in my Professional Development }\end{array}$ & $\begin{array}{l}\text { 10.a. If you Agreed or Strongly Agreed with this statement please list } \\
\text { the strategy(ies) you used to accomplish it. }\end{array}$ \\
\hline $\begin{array}{l}\text { Our professional development program prepared participants to: } \\
\text { 11. design and facilitate learning experiences that use assistive } \\
\text { technologies to meet the special plyysical needs of students. } \\
\text { O Strongly Agree (Provide Strategios) } \\
\text { O Agree (Provide Strateglo) } \\
\text { O Disagree } \\
\text { O Strongly Disagree } \\
\text { O Not Applied in my Professional Development }\end{array}$ & $\begin{array}{l}\text { 11.a. If you Agreed or Strongly Agreed with this statement please list } \\
\text { the strategy(ies) you used to accomplish it. }\end{array}$ \\
\hline $\begin{array}{l}\text { Our professional development program prepared participants to: } \\
\text { 12. guide collaborative learning activities in which students use } \\
\text { technology resources to solve authentic problems in the subject } \\
\text { area (s). } \\
\text { O Strongly Agree (Provide Strategies) } \\
\text { O Agree (Provide Stratgiaf) } \\
\text { O Disagree } \\
\text { O Strongly Disagree } \\
\text { O Not Applied in my Professional Development }\end{array}$ & $\begin{array}{l}\text { 12.a. If you Agreed or Strongly Agreed with this statement please list } \\
\text { the strategy(ies) you used to accomplish it. }\end{array}$ \\
\hline
\end{tabular}




\begin{tabular}{|c|c|}
\hline Our professional development program prepared participants to: & $\begin{array}{l}\text { 13.a. If you Agreed or Strongly Agreed with this statement please list } \\
\text { the strategy(ies) you used to accomplish it. }\end{array}$ \\
\hline $\begin{array}{l}\text { 13. arrange equitable access to appropriate technology resources } \\
\text { that enable students to engage successfully in learning activities } \\
\text { across subject/content areas and grade levels. }\end{array}$ & \\
\hline O Strongly Agree (Provile Stratggios) & \\
\hline O Agree (Provide Strategia) & \\
\hline O Disagree & \\
\hline O Strongly Disagree & \\
\hline O Not Applied in my Professional Development & \\
\hline Our professional development program prepared participants to: & $\begin{array}{l}\text { 14.a. If you Agreed or Strongly Agreed with this statement please list } \\
\text { the strategy (ies) you used to accomplish it. }\end{array}$ \\
\hline $\begin{array}{l}\text { 14. plan and implement technology-based learning activities that } \\
\text { promote student engagement in analysis, synthesis, interpretation, } \\
\text { and creation of original products. }\end{array}$ & \\
\hline O Strongly Agree (Provite Strategles) & \\
\hline O Agree (Prowile Strategies) & \\
\hline O Disagree & \\
\hline O Strongly Disagree & \\
\hline O Not Applied in my Professional Development & \\
\hline Our professional development program prepared participants to: & $\begin{array}{l}\text { 15.a. If you Agreed or Strongly Agreed with this statement please list } \\
\text { the strategy(ies) you used to accomplish it. }\end{array}$ \\
\hline $\begin{array}{l}\text { 15. facilitate students' use of technology that addresses their social } \\
\text { needs and cultural identity. }\end{array}$ & \\
\hline O Strongly Agree (Provide Strategie) & \\
\hline O Agree (Provide Strategies) & \\
\hline O Disagree & \\
\hline O Strongly Disagree & \\
\hline O Not Applied in my Professional Development & \\
\hline Our professional development program prepared participants to: & $\begin{array}{l}\text { 16.a. If you Agreed or Strongly Agreed with this statement please list } \\
\text { the strategy(ies) you used to accomplish it. }\end{array}$ \\
\hline $\begin{array}{l}\text { 16. facilitate students' use of technology that promotes their } \\
\text { interaction with the global community. }\end{array}$ & \\
\hline O Strongly Agree (Provide Stratogies) & \\
\hline O Agree (Provide Strafegia) & \\
\hline O Disagree & \\
\hline O Strongly Disagree & \\
\hline O Not Applied in my Professional Development & \\
\hline
\end{tabular}




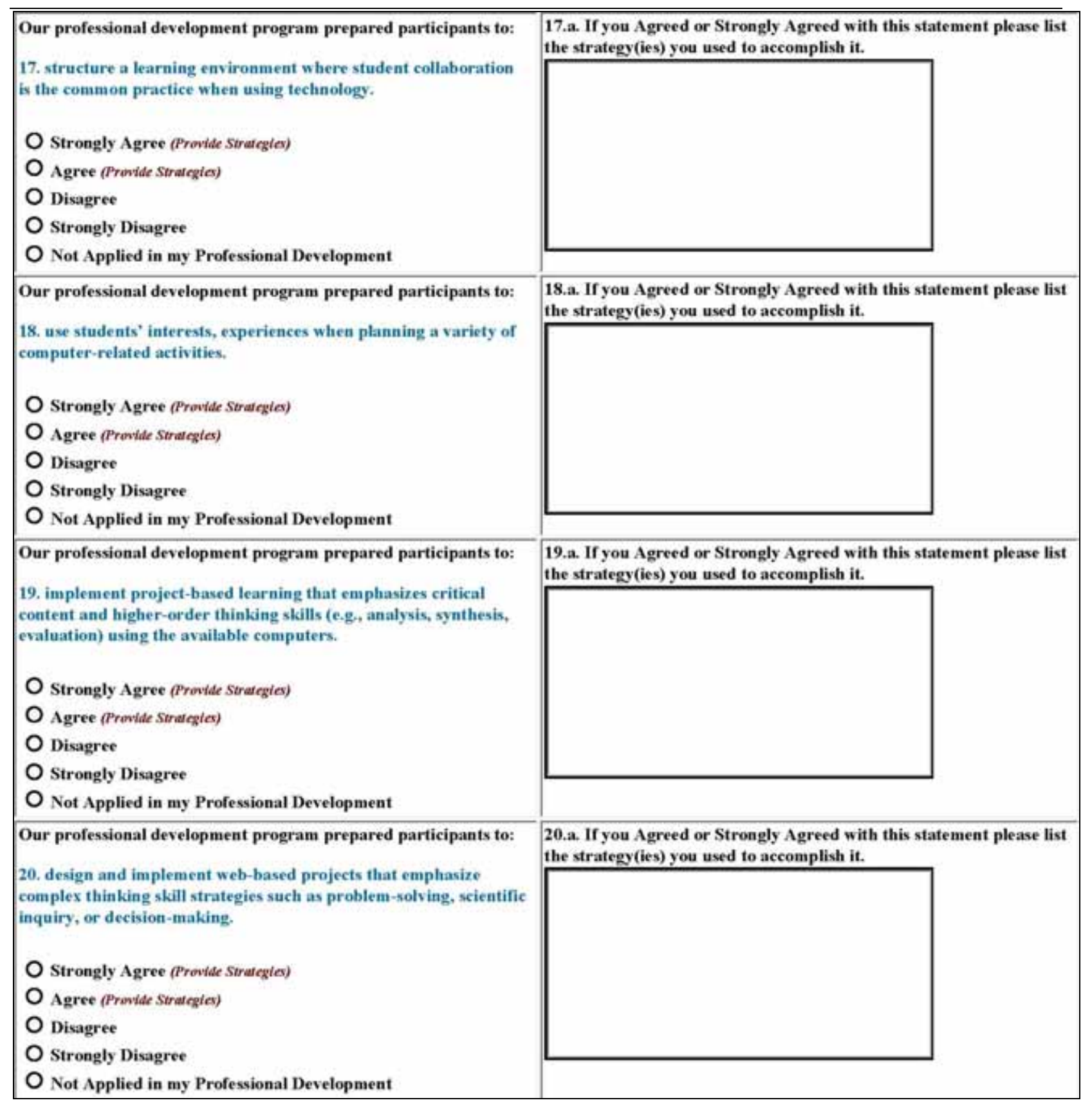




\begin{tabular}{|c|c|}
\hline Our professional development program prepared participants to: & $\begin{array}{l}\text { 21.a. If you Agreed or Strongly Agreed with this statement please list } \\
\text { the strategy(ies) you used to accomplish it. }\end{array}$ \\
\hline $\begin{array}{l}\text { 21. guide students' use of the Internet for collaboration with others. } \\
\text { O Strongly Agree (Pravide Strutegies) } \\
\text { O Agree (Provide Strategio) } \\
\text { O Disagree } \\
\text { O Strongly Disagree } \\
\text { O Not Applied in my Professional Development }\end{array}$ & \\
\hline $\begin{array}{l}\text { Our professional development program prepared participants to: } \\
\text { 22. use content-specific tools (e.g., software, simulation, web tools) } \\
\text { to support learning } \\
\text { O Strongly Agree (Provide Strutegie) } \\
\text { O Agree (Prowide Strategles) } \\
\text { O Disagree } \\
\text { O Strongly Disagree } \\
\text { O Not Applied in my Professional Development }\end{array}$ & $\begin{array}{l}\text { 22.a. If you Agreed or Strongly Agreed with this statement please list } \\
\text { the strategy(ies) you used to accomplish it. }\end{array}$ \\
\hline $\begin{array}{l}\text { Our professional development program prepared participants to: } \\
\text { 23. use technology resources to facilitate knowledge construction. } \\
\text { O Strongly Agree (Provide Strutegles) } \\
\text { O Agree (Prowide Sirategle) } \\
\text { O Disagree } \\
\text { O Strongly Disagree } \\
\text { O Not Applied in my Professional Development }\end{array}$ & $\begin{array}{l}\text { 23.a. If you Agreed or Strongly Agreed with this statement please list } \\
\text { the strategy(ies) you used to accomplish it. }\end{array}$ \\
\hline $\begin{array}{l}\text { Our professional development program prepared participants to: } \\
\text { 24. apply technology tools and resources to collect, analyze, and } \\
\text { interpret data and report results. } \\
\text { O Strongly Agree (Provide Strategles) } \\
\text { O Agree (Provide Strategies) } \\
\text { O Disagree } \\
\text { O Strongly Disagree } \\
\text { O Not Applied in my Professional Development }\end{array}$ & $\begin{array}{l}\text { 24.a. If you Agreed or Strongly Agreed with this statement please list } \\
\text { the strategy(ies) you used to accomplish it. }\end{array}$ \\
\hline
\end{tabular}




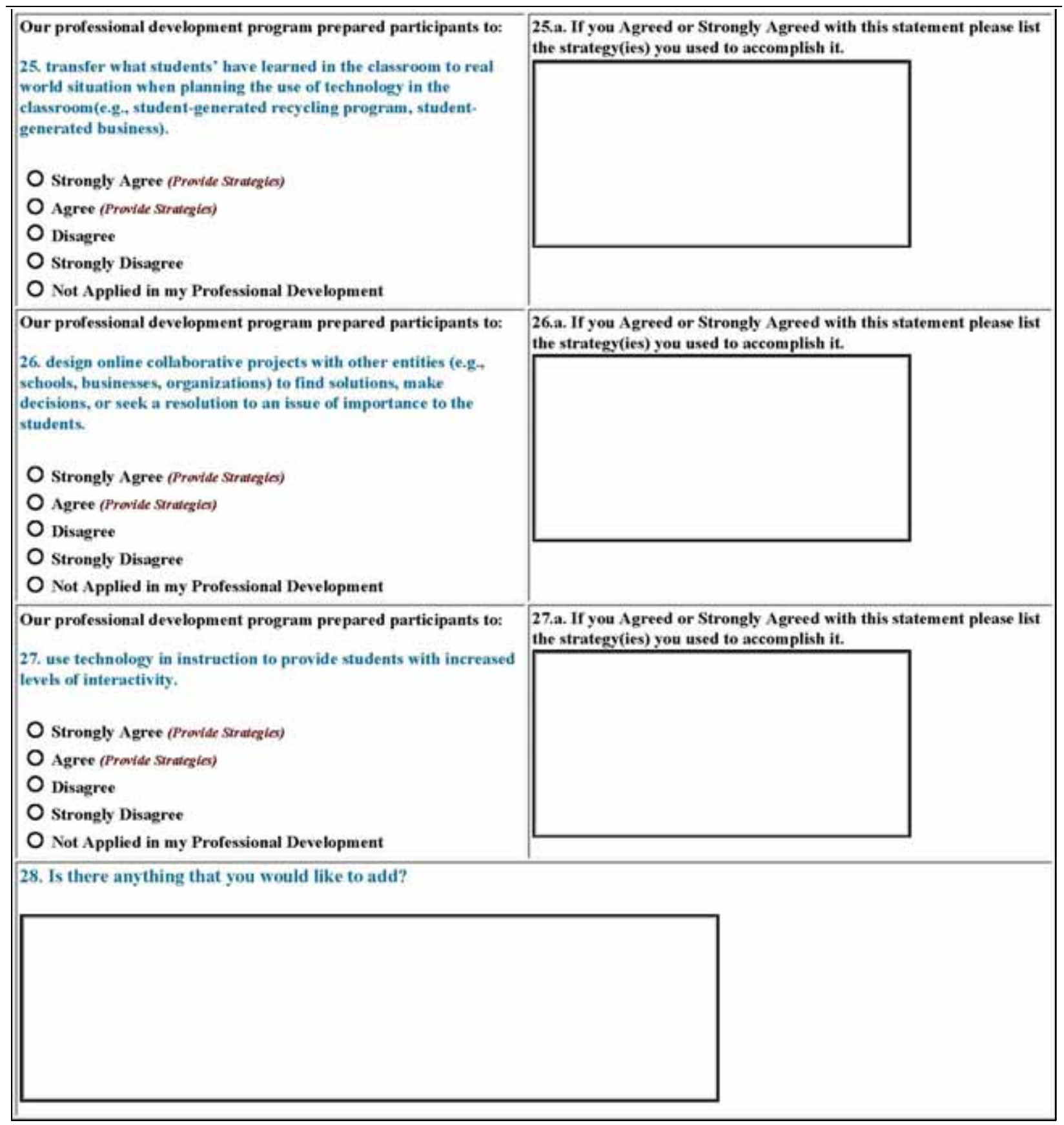


APPENDIX C

INTRODUCTION E-MAIL TO PARTICIPANTS 


\section{Subject: PT3 Research Request}

Dear $<$ participant's name $>$,

I am a doctoral student in the Technology Education program at West Virginia University conducting a study on successful PT3 professional development projects. As a project who exemplifies successful IT integration, you are being asked to participate.

My study aims to identify those strategies you employed in your sustainable instructional technology professional development program that are found to successfully promote educators' highlevel use of technology in their teaching practice. Your participation will contribute to the development of a taxonomy of strategies to guide future professional developments. The resulting taxonomy will be made available for your use.

Participation in this study is relatively easy and involves completing one short online questionnaire. I estimate it will take approximately 20-30 minutes to complete it. Your participation is critical. However, if for some reason you are not able to participate, I ask that you identify the next best person who could complete the questionnaire on behalf of your program. Indicating this person to me is very much appreciated and it will allow the success of this study. I am encouraging participants to complete this survey within one week of receiving this e-mail. Should you choose to participate please follow the steps outlined below:

1. Go to questionnaire's online address

2. Please read the information and then click on the "Click to Begin the Questionnaire" link at the bottom of the page.

3. Login with your Username: <participant's username> and Password: <participant's username>.

4. After completing the survey please click on the Submit button at the end of the page.

Note:_Take the time you need to complete the questionnaire. You will not be timed out. However, you must complete it once you started it. You cannot close it and then come back

Your participation is voluntary, and you may refrain from answering any or all questions without explanation. Please note that your responses are appreciated and will add to the validity of the study. Confidentiality and anonymity of your responses will be protected throughout the study.

If you have any questions or comments concerning this study, please feel free to contact me at (304-599-4196) or kassis@mix.wvu.edu or contact my faculty advisor, Dr. John Wells at (304- 2933803 ext.1703) or jgwells@mail.wvnet.edu . This survey was approved by the Institutional Review Board for the Protection of Human Subjects at West Virginia University.

Your participation in this study means a great deal to me personally but will also contribute to my profession, thank you for your time and effort in participating in this research.

Sincerely,

Karla Assis

Doctoral Student - Technology Education

West Virginia University

$<$ Address $>$

Morgantown - WV 26505 - <Telephone> 
APPENDIX D

INSTITUTIONAL REVIEW BOARD APPROVAL 


\section{WestVirginiaUniversity}

College of Human Resources and Education

May 10, 2004

\section{MEMORANDUM}

TO:

FROM: Lynn Cartwright Interim Associate Dean

RE: $\quad$ Human Resources \& Education H.S. \#2004-034

\section{Title: "Strategies for Sustainable Professional Development Programs to Promote Effective Pedagogical Use of Instructional Technology in Teaching"}

Your Application for Exemption for the above-captioned research project has been reviewed under the Human Subjects Policies and has been approved.

This exemption will remain in effect on the condition that the research is carried out exactly as described in the application.

Best wishes for the success of your research.

cc: Deans Office

Student Advising and Records

John Wells, Advisor

Office of the Dean 
APPENDIX E

THANK-YOU CARD AND THANK YOU MAGNET 


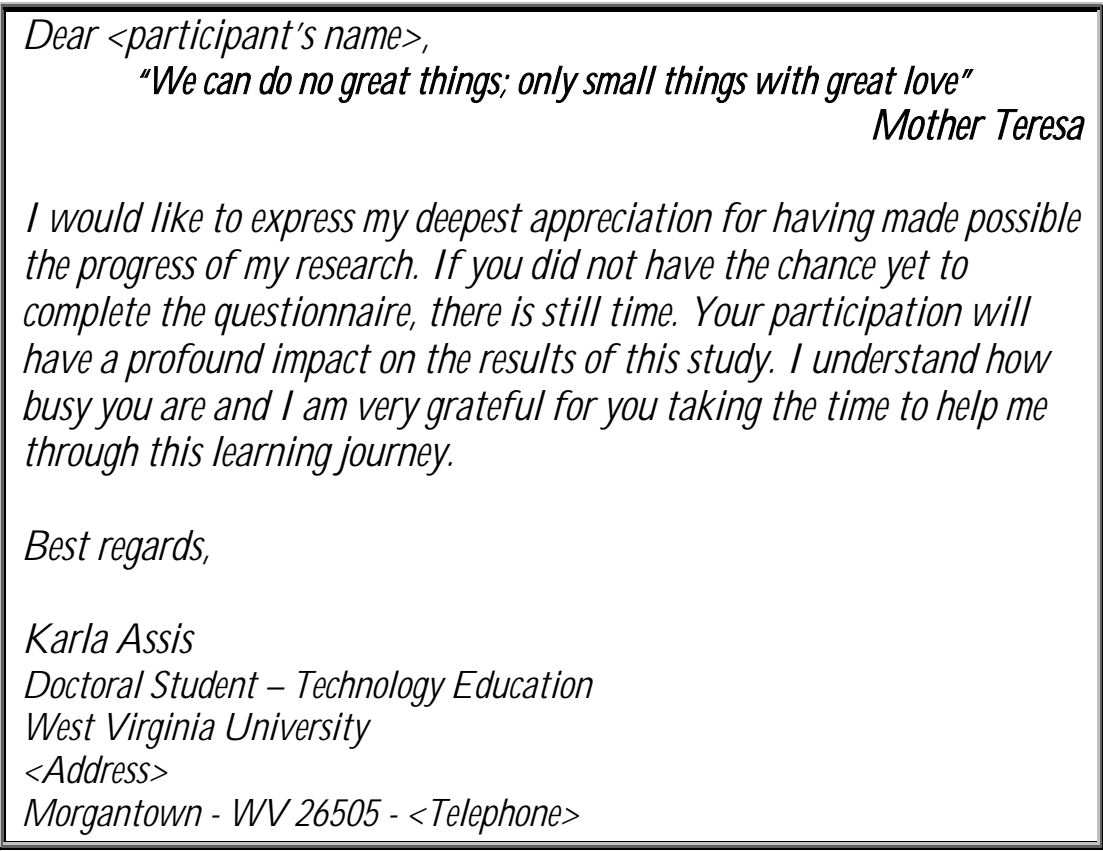

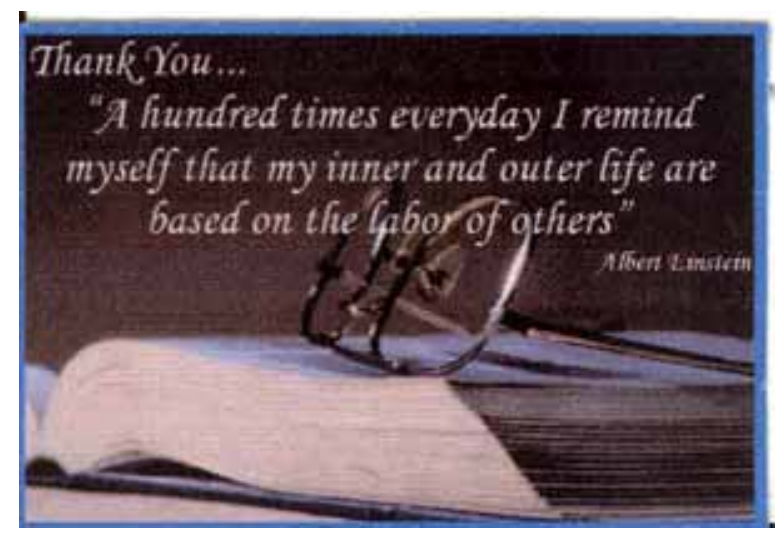


APPENDIX F

FIRST E-MAIL REMINDER 
Subject: PT3 Research - Reminder

Dear [Participant's Name],

This is a follow up to the previous e-mail I sent asking you to participate in my study. I am aware of your busy schedule, but if you could spare approximately 20 to 30 minutes of your time and complete the online questionnaire (questionnaire's web address) it would mean a lot for my research. The questionnaire will be available for completion for one more week. The data collection will end at midnight on May 29, 2004. If you want to participate in this study but you do not have the time to complete the survey please indicate the next best person who could complete the questionnaire in behalf of your program.

To participate in this study please click on the questionnaire's link above, read the information and click on the link Click to Begin Questionnaire at the bottom of the page. You will be prompted to enter the user name: $<>$ and the password: $<>$. After completing the questionnaire click on the Submit button on the bottom of the page.

Thank you for your time and for considering completing the questionnaire!

If you have any question, feel free to contact me at (304-599-4196) or kassis@mix.wvu.edu or contact my faculty advisor, Dr. John Wells at (304- 2933803 ext. 1703) or jgwells@mail.wvnet.edu . This questionnaire was approved by the Institutional Review Board for the Protection of Human Subjects at West Virginia University

Sincerely,

Karla Assis

Doctoral Student - Technology Education

West Virginia University

Address - Telephone 
APPENDIX G

FINAL E-MAIL REMINDER 
Subject: PT3 Research - Reminder

Dear [Participant's Name],

Time to participate is running out. The data collection for this study will end on May 29, 2004. Your participation is crucial for this study. I would really appreciate if you could take approximately 20 to 30 minutes of your busy schedule to complete this online questionnaire (questionnaire's web address). I therefore thank you in advance for considering taking your time to complete this questionnaire.

To participate in this study please click on the questionnaire's link, read the information and click on the link Click to Begin Questionnaire at the bottom of the page. You will be prompted to enter the user name: $<>$ and the password: $<>$. After completing the questionnaire click on the Submit button on the bottom of the page.

Thank you very much for your time.

If you have any question, feel free to contact me at (304-599-4196) or kassis@,mix.wvu.edu or contact my faculty advisor, Dr. John Wells at (304- 2933803 ext. 1703) or jgwells@mail.wvnet.edu . This questionnaire was approved by the Institutional Review Board for the Protection of Human Subjects at West Virginia University.

Sincerely,

Karla Assis

Doctoral Student - Technology Education

West Virginia University

Address - Telephone 
APPENDIX H

THANK-YOU E-MAIL 


\section{Subject: PT3 Research - Thank you}

Dear (participant's name)

I would like to thank you for taking the time to complete the questionnaire. Your participation meant a lot to my study. When the study is completed I will make available the results to you. I am grateful for your support and your efforts to contribute to the success of this study.

Have a wonderful summer!

Best regards,

Karla Assis

Doctoral Student - Technology Education

West Virginia University

$<$ Address $>$

Morgantown - WV 26505 - <Telephone> 


\section{APPENDIX I \\ INTRARESPONDENT MATRIX TEMPLATE \\ GENERATING CODING FROM PARTICIPANTS' RESPONSES}


Intrarespondent Matrix Template - Generating Coding from Participants’ Responses

Indicator \#: Question statement.

\section{Category in which the indicatorbelongs}

\begin{tabular}{|l|l|l|l|}
\hline Par & Participants Responses & Researcher Coding & Suggestions by Expert \\
\hline 1. & & \\
\hline 2. & & & \\
\hline 3. & & & \\
\hline 4. & 5. & & \\
\hline 6. & . & & \\
\hline
\end{tabular}

\section{Example:}

Indicator 1: Our professional development program prepared participants to differentiate between appropniate and inappropniate uses of technology for students' grade level and content area. If you Agreed or Strongly Agreed with this statement please list the strategy (ies) that you used to accomplish it.

\section{Category 4: Appropniate Use of Instructional Technology}

\begin{tabular}{|l|l|l|l|}
\hline Par & Participants Responses & Researcher Coding & Suggestions by Expert \\
\hline 1. & & & \\
\hline 2. & & & \\
\hline 3. & P. & & \\
\hline 5. & P. & & \\
\hline 7. & & & \\
\hline
\end{tabular}


APPENDIX J

HIGH-LEVEL USE OF TECHNOLOGY: PERCENT/FREQUENCY 
High-Level Use of Technology: Percent/Frequency

QUEST1

\begin{tabular}{cccccc}
\hline & & Frequency & Percent & Valid Percent & $\begin{array}{c}\text { Cumulative } \\
\text { Percent }\end{array}$ \\
\hline & 1 & 1 & 1.4 & 1.4 & 1.4 \\
& 2 & 9 & 12.9 & 12.9 & 14.3 \\
Valid & 3 & 7 & 10.0 & 10.0 & 24.3 \\
& 4 & 30 & 42.9 & 42.9 & 67.1 \\
& 5 & 23 & 32.9 & 32.9 & 100.0 \\
\cline { 2 - 5 } & & & & & \\
\hline
\end{tabular}

QUEST2

\begin{tabular}{cccccc}
\hline & & Frequency & Percent & Valid Percent & Cumulative \\
& & & & & Percent \\
\hline \multirow{2}{*}{ Valid } & 3 & 4 & 5.7 & 5.7 & 5.7 \\
& 3 & 3 & 4.3 & 4.3 & 10.0 \\
& 5 & 35 & 50.0 & 50.0 & 60.0 \\
\cline { 2 - 5 } & & 28 & 40.0 & 40.0 & 100.0 \\
\hline
\end{tabular}

QUEST3

\begin{tabular}{lccccc}
\hline & & Frequency & Percent & Valid Percent & $\begin{array}{c}\text { Cumulative } \\
\text { Percent }\end{array}$ \\
\hline \multirow{4}{*}{ Valid } & 2 & 3 & 4.3 & 4.3 & 4.3 \\
& 3 & 4 & 5.7 & 5.7 & 10.0 \\
& 5 & 36 & 51.4 & 51.4 & 61.4 \\
& 5 & 27 & 38.6 & 38.6 & 100.0 \\
\hline
\end{tabular}


High-Level Use of Technology: Percent/Frequency (continued)

\section{QUEST4}

\begin{tabular}{|c|c|c|c|c|c|}
\hline & & Frequency & Percent & Valid Percent & $\begin{array}{c}\text { Cumulative } \\
\text { Percent }\end{array}$ \\
\hline \multirow{5}{*}{ Valid } & 2 & 4 & 5.7 & 6.0 & 6.0 \\
\hline & 3 & 6 & 8.6 & 9.0 & 14.9 \\
\hline & 4 & 24 & 34.3 & 35.8 & 50.7 \\
\hline & 5 & 33 & 47.1 & 49.3 & 100.0 \\
\hline & Total & 67 & 95.7 & 100.0 & \\
\hline \multirow[t]{2}{*}{ Missing } & System & 3 & 4.3 & & \\
\hline & & 70 & 100.0 & & \\
\hline
\end{tabular}

QUEST5

\begin{tabular}{|c|c|c|c|c|c|}
\hline & & Frequency & Percent & Valid Percent & $\begin{array}{c}\text { Cumulative } \\
\text { Percent }\end{array}$ \\
\hline \multirow{5}{*}{ Valid } & 2 & 10 & 14.3 & 14.5 & 14.5 \\
\hline & 3 & 15 & 21.4 & 21.7 & 36.2 \\
\hline & 4 & 20 & 28.6 & 29.0 & 65.2 \\
\hline & 5 & 24 & 34.3 & 34.8 & 100.0 \\
\hline & Total & 69 & 98.6 & 100.0 & \\
\hline \multirow[t]{2}{*}{ Missing } & System & 1 & 1.4 & & \\
\hline & & 70 & 100.0 & & \\
\hline
\end{tabular}


High-Level Use of Technology: Percent/Frequency (continued)

\section{QUEST6}

\begin{tabular}{cccccc}
\hline & & Frequency & Percent & Valid Percent & Cumulative \\
& 2 & 5 & 7.1 & 7.2 & Percent \\
\hline \multirow{2}{*}{ Valid } & 3 & 7 & 10.0 & 10.1 & 7.2 \\
& 4 & 29 & 41.4 & 42.0 & 17.4 \\
& 5 & 28 & 40.0 & 40.6 & 100.0 \\
\cline { 2 - 6 } & Total & 69 & 98.6 & 100.0 & \\
\hline Missing & System & 1 & 1.4 & & \\
\hline Total & & 70 & 100.0 & & \\
\hline
\end{tabular}

QUEST7

\begin{tabular}{cccccc}
\hline & & Frequency & Percent & Valid Percent & $\begin{array}{c}\text { Cumulative } \\
\text { Percent }\end{array}$ \\
\hline \multirow{4}{*}{ Valid } & 2 & 4 & 5.7 & 6.2 & 6.2 \\
& 3 & 5 & 7.1 & 7.7 & 13.8 \\
& 4 & 20 & 28.6 & 30.8 & 44.6 \\
& 5 & 36 & 51.4 & 55.4 & 100.0 \\
\cline { 2 - 6 } & & & & & \\
\hline Missing & Total & 65 & 92.9 & 100.0 & \\
\hline \multicolumn{7}{c}{ Total } & & 70 & 100.0 & & \\
\hline
\end{tabular}


High-Level Use of Technology: Percent/Frequency (continued)

\section{QUEST8}

\begin{tabular}{|c|c|c|c|c|c|}
\hline & & Frequency & Percent & Valid Percent & $\begin{array}{c}\text { Cumulative } \\
\text { Percent }\end{array}$ \\
\hline \multirow{5}{*}{ Valid } & 2 & 6 & 8.6 & 8.7 & 8.7 \\
\hline & 3 & 9 & 12.9 & 13.0 & 21.7 \\
\hline & 4 & 31 & 44.3 & 44.9 & 66.7 \\
\hline & 5 & 23 & 32.9 & 33.3 & 100.0 \\
\hline & Total & 69 & 98.6 & 100.0 & \\
\hline \multirow[t]{2}{*}{ Missing } & System & 1 & 1.4 & & \\
\hline & & 70 & 100.0 & & \\
\hline
\end{tabular}

QUEST9

\begin{tabular}{cccccc}
\hline & & Frequency & Percent & Valid Percent & $\begin{array}{c}\text { Cumulative } \\
\text { Percent }\end{array}$ \\
\hline \multirow{6}{*}{ Valid } & 1 & 1 & 1.4 & 1.4 & 1.4 \\
& 2 & 19 & 27.1 & 27.5 & 29.0 \\
& 3 & 14 & 20.0 & 20.3 & 49.3 \\
& 4 & 21 & 30.0 & 30.4 & 79.7 \\
& 5 & 14 & 20.0 & 20.3 & 100.0 \\
\cline { 2 - 6 } & Total & 69 & 98.6 & 100.0 & \\
\hline Missing & System & 1 & 1.4 & & \\
\hline \multicolumn{7}{c}{ Total } & & 70 & 100.0 & & \\
\hline
\end{tabular}


High-Level Use of Technology: Percent/Frequency (continued)

QUEST10

\begin{tabular}{cccccc}
\hline & & Frequency & Percent & Valid Percent & $\begin{array}{c}\text { Cumulative } \\
\text { Percent }\end{array}$ \\
\hline & 1 & 1 & 1.4 & 1.4 & 1.4 \\
& 2 & 14 & 20.0 & 20.0 & 21.4 \\
Valid & 3 & 14 & 20.0 & 20.0 & 41.4 \\
& 4 & 25 & 35.7 & 35.7 & 77.1 \\
& 5 & 16 & 22.9 & 22.9 & 100.0 \\
\hline
\end{tabular}

QUEST11

\begin{tabular}{lccccc}
\hline & & Frequency & Percent & Valid Percent & Cumulative \\
& 2 & 15 & 21.4 & 21.7 & Percent \\
\hline \multirow{2}{*}{ Valid } & 3 & 20 & 28.6 & 29.0 & 50.7 \\
& 4 & 27 & 38.6 & 39.1 & 89.9 \\
& 5 & 7 & 10.0 & 10.1 & 100.0 \\
\cline { 2 - 6 } & Total & 69 & 98.6 & 100.0 & \\
\hline Missing & System & 1 & 1.4 & & \\
\hline Total & & 70 & 100.0 & & \\
\hline
\end{tabular}

QUEST12

\begin{tabular}{lccccc}
\hline & & Frequency & Percent & Valid Percent & Cumulative \\
& & & & & Percent \\
\hline \multirow{2}{*}{ Valid } & 4 & 4 & 5.7 & 5.7 & 5.7 \\
& 3 & 14 & 20.0 & 20.0 & 25.7 \\
& 5 & 29 & 41.4 & 41.4 & 67.1 \\
& & 23 & 32.9 & 32.9 & 100.0 \\
\cline { 2 - 6 } & Total & 70 & 100.0 & 100.0 & \\
\hline
\end{tabular}


High-Level Use of Technology: Percent/Frequency (continued)

\section{QUEST13}

\begin{tabular}{|c|c|c|c|c|c|}
\hline & & Frequency & Percent & Valid Percent & $\begin{array}{c}\text { Cumulative } \\
\text { Percent }\end{array}$ \\
\hline \multirow{8}{*}{ Valid } & 1 & 1 & 1.4 & 1.4 & 1.4 \\
\hline & 2 & 14 & 20.0 & 20.0 & 21.4 \\
\hline & 3 & 15 & 21.4 & 21.4 & 42.9 \\
\hline & 4 & 23 & 32.9 & 32.9 & 75.7 \\
\hline & 5 & 17 & 24.3 & 24.3 & 100.0 \\
\hline & Total & 70 & 100.0 & 100.0 & \\
\hline & \multicolumn{4}{|c|}{ QUEST14 } & \\
\hline & & Frequency & Percent & Valid Percent & $\begin{array}{c}\text { Cumulative } \\
\text { Percent }\end{array}$ \\
\hline \multirow{5}{*}{ Valid } & 2 & 4 & 5.7 & 5.8 & 5.8 \\
\hline & 3 & 11 & 15.7 & 15.9 & 21.7 \\
\hline & 4 & 30 & 42.9 & 43.5 & 65.2 \\
\hline & 5 & 24 & 34.3 & 34.8 & 100.0 \\
\hline & Total & 69 & 98.6 & 100.0 & \\
\hline Missing & System & 1 & 1.4 & & \\
\hline \multicolumn{2}{|c|}{ Total } & 70 & 100.0 & & \\
\hline
\end{tabular}


High-Level Use of Technology: Percent/Frequency (continued)

QUEST15

\begin{tabular}{lccccc}
\hline & & Frequency & Percent & Valid Percent & Cumulative \\
& 2 & 18 & 25.7 & 26.9 & Percent \\
\hline \multirow{2}{*}{ Valid } & 3 & 21 & 30.0 & 31.3 & 58.2 \\
& 4 & 22 & 31.4 & 32.8 & 91.0 \\
& 5 & 6 & 8.6 & 9.0 & 100.0 \\
\cline { 2 - 6 } & Total & 67 & 95.7 & 100.0 & \\
\hline Missing & System & 3 & 4.3 & & \\
\hline Total & & & & & \\
\hline
\end{tabular}

\begin{tabular}{lccccc}
\hline & & Frequency & Percent & Valid Percent & $\begin{array}{c}\text { Cumulative } \\
\text { Percent }\end{array}$ \\
\hline & 2 & 18 & 25.7 & 25.7 & 25.7 \\
Valid & 3 & 19 & 27.1 & 27.1 & 52.9 \\
& 5 & 23 & 32.9 & 32.9 & 85.7 \\
& 5 & 10 & 14.3 & 14.3 & 100.0 \\
\cline { 2 - 6 } & & & & & \\
\hline
\end{tabular}

\begin{tabular}{|c|c|c|c|c|c|}
\hline & & Frequency & Percent & Valid Percent & $\begin{array}{c}\text { Cumulative } \\
\text { Percent }\end{array}$ \\
\hline \multirow{5}{*}{ Valid } & 2 & 6 & 8.6 & 8.8 & 8.8 \\
\hline & 3 & 8 & 11.4 & 11.8 & 20.6 \\
\hline & 4 & 32 & 45.7 & 47.1 & 67.6 \\
\hline & 5 & 22 & 31.4 & 32.4 & 100.0 \\
\hline & Total & 68 & 97.1 & 100.0 & \\
\hline \multirow[t]{2}{*}{ Missing } & System & 2 & 2.9 & & \\
\hline & & 70 & 100.0 & & \\
\hline
\end{tabular}


High-Level Use of Technology: Percent/Frequency (continued)

QUEST18

\begin{tabular}{|c|c|c|c|c|c|}
\hline & & Frequency & Percent & Valid Percent & $\begin{array}{c}\text { Cumulative } \\
\text { Percent }\end{array}$ \\
\hline \multirow{5}{*}{ Valid } & 2 & 8 & 11.4 & 11.8 & 11.8 \\
\hline & 3 & 15 & 21.4 & 22.1 & 33.8 \\
\hline & 4 & 27 & 38.6 & 39.7 & 73.5 \\
\hline & 5 & 18 & 25.7 & 26.5 & 100.0 \\
\hline & Total & 68 & 97.1 & 100.0 & \\
\hline \multirow[t]{6}{*}{ Missing } & System & 2 & 2.9 & & \\
\hline & \multirow[t]{3}{*}{ otal } & 70 & 100.0 & & \\
\hline & & \multicolumn{3}{|c|}{ QUEST19 } & \\
\hline & & Frequency & Percent & Valid Percent & $\begin{array}{c}\text { Cumulative } \\
\text { Percent }\end{array}$ \\
\hline & 2 & 9 & 12.9 & 13.2 & 13.2 \\
\hline & 3 & 11 & 15.7 & 16.2 & 29.4 \\
\hline \multirow[t]{3}{*}{ Valid } & 4 & 23 & 32.9 & 33.8 & 63.2 \\
\hline & 5 & 25 & 35.7 & 36.8 & 100.0 \\
\hline & Total & 68 & 97.1 & 100.0 & \\
\hline \multirow[t]{2}{*}{ Missing } & System & 2 & 2.9 & & \\
\hline & & 70 & 100.0 & & \\
\hline
\end{tabular}


High-Level Use of Technology: Percent/Frequency (continued)

QUEST20

\begin{tabular}{cccccc}
\hline & & Frequency & Percent & Valid Percent & Cumulative \\
& 1 & 1 & 1.4 & 1.5 & 1.5 \\
& 2 & 11 & 15.7 & 16.9 & 18.5 \\
\multirow{2}{*}{ Valid } & 3 & 12 & 17.1 & 18.5 & 36.9 \\
& 4 & 18 & 25.7 & 27.7 & 64.6 \\
& 5 & 23 & 32.9 & 35.4 & 100.0 \\
\cline { 2 - 6 } & Total & 65 & 92.9 & 100.0 & \\
\hline Missing & System & 5 & 7.1 & & \\
\hline \multicolumn{2}{l}{ Total } & 70 & 100.0 & & \\
\hline
\end{tabular}

QUEST21

\begin{tabular}{|c|c|c|c|c|c|}
\hline & & Frequency & Percent & Valid Percent & $\begin{array}{c}\text { Cumulative } \\
\text { Percent }\end{array}$ \\
\hline \multirow{5}{*}{ Valid } & 2 & 11 & 15.7 & 16.4 & 16.4 \\
\hline & 3 & 16 & 22.9 & 23.9 & 40.3 \\
\hline & 4 & 21 & 30.0 & 31.3 & 71.6 \\
\hline & 5 & 19 & 27.1 & 28.4 & 100.0 \\
\hline & Total & 67 & 95.7 & 100.0 & \\
\hline \multirow[t]{2}{*}{ Missing } & System & 3 & 4.3 & & \\
\hline & & 70 & 100.0 & & \\
\hline
\end{tabular}


High-Level Use of Technology: Percent/Frequency (continued)

\begin{tabular}{cccccc}
\multicolumn{7}{c}{ QUEST22 } & & \\
\hline & & Frequency & Percent & Valid Percent & Cumulative \\
Percent
\end{tabular}


High-Level Use of Technology: Percent/Frequency (continued)

\section{QUEST24}

\begin{tabular}{cccccc}
\hline & & Frequency & Percent & Valid Percent & $\begin{array}{c}\text { Cumulative } \\
\text { Percent }\end{array}$ \\
\hline \multirow{2}{*}{ Valid } & 2 & 10 & 14.3 & 14.9 & 14.9 \\
& 3 & 10 & 14.3 & 14.9 & 29.9 \\
& 5 & 30 & 42.9 & 44.8 & 74.6 \\
\cline { 2 - 6 } & 5 & 17 & 24.3 & 25.4 & 100.0 \\
\hline Missing & Total & 67 & 95.7 & 100.0 & \\
\hline Tystem & 3 & 4.3 & & \\
\hline
\end{tabular}

QUEST25

\begin{tabular}{cccccc}
\hline & & Frequency & Percent & Valid Percent & $\begin{array}{c}\text { Cumulative } \\
\text { Percent }\end{array}$ \\
\hline \multirow{5}{*}{ Valid } & 1 & 1 & 1.4 & 1.5 & 1.5 \\
& 2 & 18 & 25.7 & 27.3 & 28.8 \\
& 3 & 22 & 31.4 & 33.3 & 62.1 \\
& 4 & 12 & 17.1 & 18.2 & 80.3 \\
& 5 & 13 & 18.6 & 19.7 & 100.0 \\
\cline { 2 - 6 } & Total & 66 & 94.3 & 100.0 & \\
\hline Missing & System & 4 & 5.7 & & \\
\hline \multicolumn{7}{c}{ Total } & & 70 & 100.0 & & \\
\hline
\end{tabular}


High-Level Use of Technology: Percent/Frequency (continued)

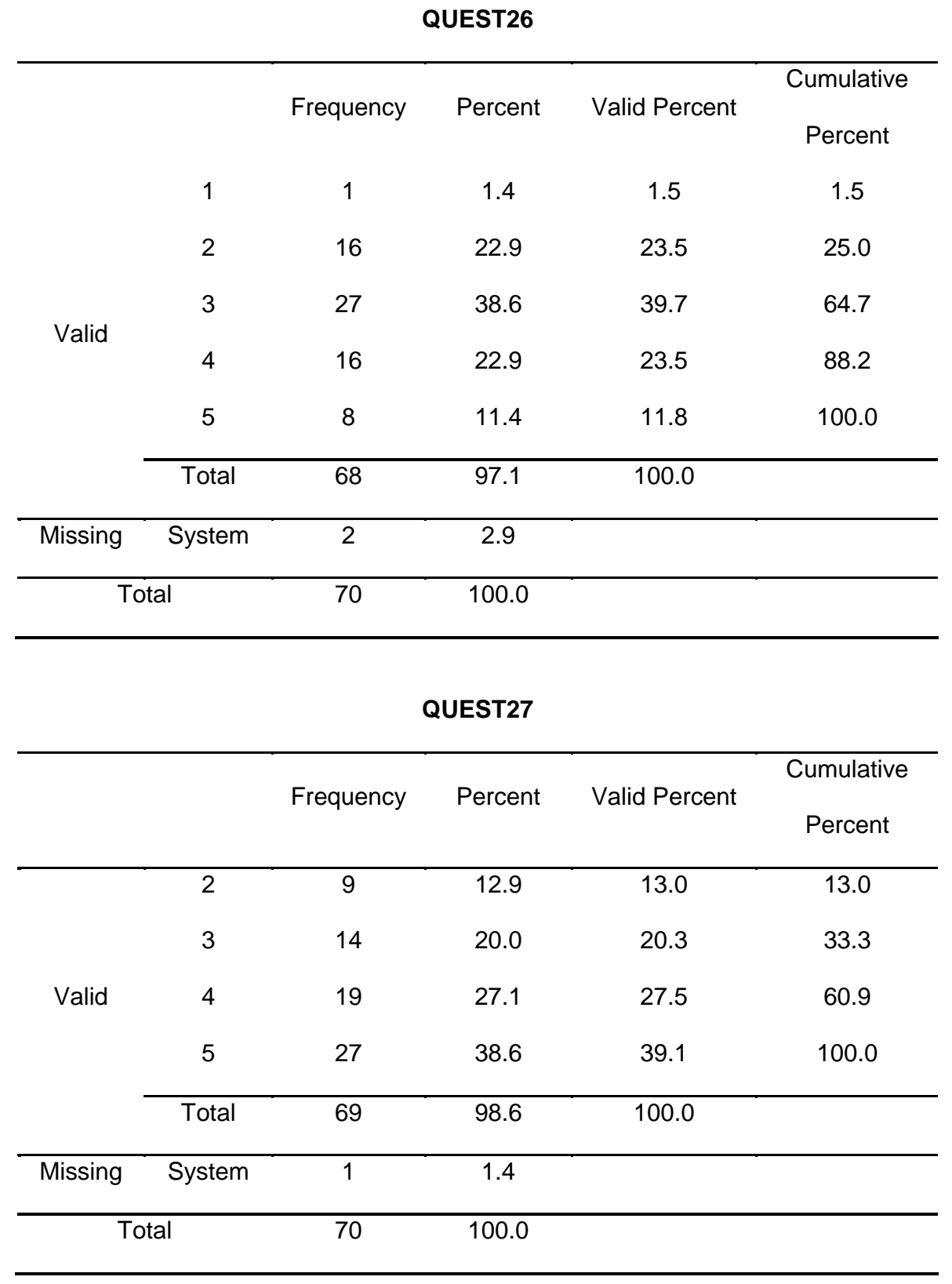




\section{APPENDIX K \\ INTERRESPONDENT MATRIX \\ SAMPLE RESULTS FROM THE ANALYSES OF PARTICIPANT CHOICE OF STRATEGIES PER INDICATOR}


Sample Results from the Interrespondent Matrix - Analyses of Participants' Choice of Strategies per Indicator

Strategies Present in Indicator 1: 51 Responses of 53 Possible Open-Ended Responses

\begin{tabular}{|c|c|c|c|c|c|c|c|c|c|c|c|c|c|c|c|c|c|c|c|c|c|c|c|c|c|c|}
\hline 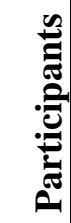 & 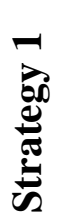 & 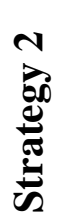 & 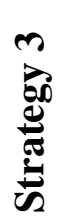 & 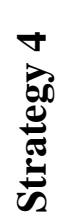 & م0 & ص & D્م & 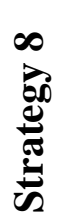 & 品 & 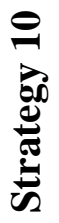 & 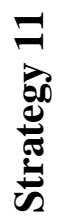 & 党 & 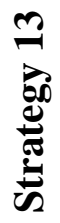 & 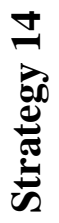 & 号 & 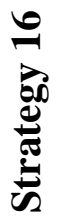 & 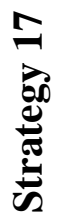 & 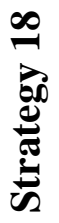 & 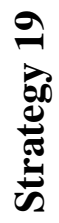 & 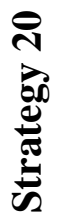 & 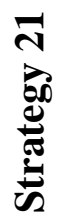 & 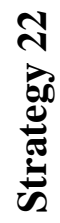 & 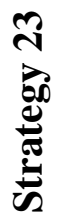 & 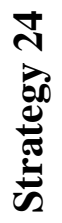 & 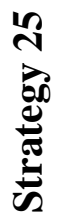 & 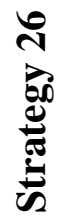 \\
\hline 1 & 1 & 0 & 0 & 0 & 0 & 1 & 0 & 0 & 0 & 0 & 0 & 0 & 0 & 0 & 0 & 0 & 0 & 0 & 0 & 1 & 0 & 0 & 0 & 0 & 0 & 0 \\
\hline 2 & 0 & 0 & 0 & 0 & 0 & 0 & 0 & 0 & 0 & 1 & 0 & 0 & 0 & 1 & 0 & 0 & 0 & 0 & 0 & 0 & 0 & 1 & 0 & 0 & 0 & 0 \\
\hline 3 & 1 & 1 & 1 & 0 & 0 & 0 & 0 & 0 & 0 & 0 & 0 & 0 & 0 & 0 & 0 & 0 & 0 & 0 & 0 & 0 & 0 & 0 & 0 & 0 & 0 & 0 \\
\hline 4 & 0 & 0 & 1 & 0 & 0 & 0 & 0 & 0 & 0 & 0 & 1 & 0 & 0 & 0 & 0 & 0 & 0 & 0 & 0 & 0 & 0 & 0 & 1 & 0 & 0 & 0 \\
\hline 7 & 1 & 0 & 0 & 0 & 0 & 0 & 0 & 0 & 0 & 0 & 0 & 0 & 0 & 0 & 0 & 0 & 1 & 0 & 0 & 0 & 0 & 0 & 0 & 0 & 0 & 0 \\
\hline 9 & 0 & 0 & 1 & 0 & 0 & 0 & 0 & 1 & 1 & 0 & 0 & 0 & 0 & 0 & 0 & 0 & 0 & 0 & 0 & 0 & 0 & 0 & 0 & 0 & 0 & 1 \\
\hline 10 & 0 & 0 & 1 & 0 & 1 & 0 & 0 & 0 & 1 & 1 & 0 & 0 & 0 & 0 & 0 & 0 & 0 & 0 & 0 & 0 & 0 & 0 & 0 & 0 & 0 & 0 \\
\hline 13 & 1 & 0 & 1 & 0 & 0 & 0 & 1 & 0 & 0 & 0 & 0 & 0 & 0 & 0 & 0 & 0 & 0 & 0 & 0 & 0 & 0 & 0 & 0 & 0 & 0 & 0 \\
\hline 14 & 0 & 0 & 0 & 0 & 0 & 0 & 0 & 0 & 0 & 1 & 1 & 0 & 0 & 0 & 0 & 0 & 0 & 0 & 0 & 0 & 0 & 0 & 0 & 0 & 0 & 0 \\
\hline 15 & 0 & 0 & 0 & 0 & 0 & 0 & 0 & 0 & 0 & 1 & 0 & 0 & 1 & 0 & 0 & 0 & 0 & 0 & 0 & 0 & 0 & 0 & 0 & 0 & 0 & 0 \\
\hline 16 & 0 & 0 & 1 & 1 & 0 & 0 & 0 & 0 & 1 & 0 & 0 & 0 & 0 & 0 & 0 & 0 & 0 & 0 & 0 & 0 & 0 & 0 & 0 & 0 & 0 & 0 \\
\hline 17 & 0 & 0 & 1 & 0 & 0 & 0 & 0 & 0 & 1 & 0 & 0 & 0 & 0 & 0 & 0 & 0 & 0 & 0 & 0 & 0 & 0 & 0 & 0 & 0 & 0 & 0 \\
\hline 19 & 0 & 0 & 1 & 0 & 0 & 0 & 0 & 0 & 1 & 0 & 0 & 0 & 0 & 0 & 0 & 0 & 0 & 0 & 0 & 0 & 0 & 1 & 0 & 0 & 0 & 0 \\
\hline 20 & 0 & 0 & 0 & 1 & 0 & 1 & 0 & 1 & 0 & 0 & 0 & 0 & 0 & 0 & 0 & 0 & 0 & 0 & 0 & 0 & 0 & 0 & 0 & 0 & 0 & 0 \\
\hline 21 & 1 & 0 & 1 & 0 & 0 & 0 & 0 & 1 & 1 & 0 & 0 & 0 & 0 & 0 & 0 & 0 & 0 & 0 & 0 & 0 & 0 & 0 & 0 & 0 & 0 & 0 \\
\hline 23 & 1 & 0 & 0 & 0 & 0 & 0 & 0 & 0 & 0 & 0 & 0 & 0 & 0 & 0 & 0 & 0 & 0 & 0 & 0 & 0 & 0 & 0 & 0 & 0 & 0 & 0 \\
\hline 25 & 1 & 0 & 0 & 0 & 0 & 0 & 0 & 0 & 0 & 0 & 0 & 0 & 0 & 0 & 0 & 0 & 0 & 0 & 0 & 0 & 0 & 0 & 0 & 0 & 0 & 0 \\
\hline 26 & 0 & 0 & 0 & 0 & 1 & 0 & 0 & 0 & 0 & 0 & 0 & 0 & 0 & 0 & 0 & 0 & 0 & 0 & 0 & 0 & 0 & 0 & 0 & 0 & 0 & 0 \\
\hline 27 & 1 & 0 & 0 & 0 & 0 & 0 & 0 & 1 & 1 & 0 & 0 & 0 & 0 & 0 & 0 & 0 & 0 & 0 & 0 & 0 & 0 & 0 & 0 & 0 & 0 & 1 \\
\hline 28 & 0 & 0 & 1 & 0 & 0 & 0 & 0 & 0 & 0 & 0 & 0 & 0 & 0 & 0 & 0 & 0 & 0 & 0 & 0 & 0 & 0 & 1 & 0 & 0 & 0 & 0 \\
\hline 29 & 0 & 0 & 0 & 0 & 0 & 0 & 0 & 0 & 1 & 0 & 0 & 0 & 0 & 0 & 0 & 0 & 0 & 0 & 0 & 1 & 0 & 0 & 0 & 0 & 0 & 1 \\
\hline 31 & 1 & 0 & 0 & 0 & 0 & 1 & 0 & 0 & 0 & 0 & 0 & 0 & 0 & 0 & 0 & 0 & 0 & 0 & 0 & 0 & 0 & 0 & 0 & 0 & 0 & 0 \\
\hline 32 & 0 & 0 & 1 & 0 & 0 & 0 & 0 & 0 & 0 & 0 & 0 & 0 & 0 & 0 & 0 & 0 & 0 & 0 & 0 & 0 & 0 & 0 & 0 & 0 & 0 & 1 \\
\hline 33 & 1 & 0 & 0 & 0 & 0 & 0 & 0 & 0 & 0 & 0 & 0 & 0 & 0 & 0 & 0 & 0 & 0 & 0 & 0 & 0 & 0 & 0 & 0 & 0 & 0 & 0 \\
\hline 34 & 1 & 0 & 1 & 0 & 0 & 0 & 0 & 0 & 1 & 0 & 0 & 1 & 0 & 0 & 0 & 0 & 0 & 0 & 0 & 0 & 0 & 0 & 0 & 0 & 0 & 0 \\
\hline 35 & 0 & 1 & 0 & 0 & 0 & 0 & 0 & 0 & 0 & 0 & 0 & 0 & 0 & 0 & 0 & 0 & 0 & 0 & 0 & 0 & 0 & 0 & 0 & 0 & 0 & 0 \\
\hline
\end{tabular}


Sample Results from the Interrespondent Matrix - Analyses of Participants' Choice of Strategies per Indicator (continued)

Strategies Present in Indicator 1: 51 Responses of 53 Possible Open-Ended Responses (continued)

\begin{tabular}{|c|c|c|c|c|c|c|c|c|c|c|c|c|c|c|c|c|c|c|c|c|c|c|c|c|c|c|}
\hline 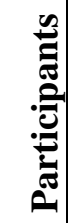 & 멍 & 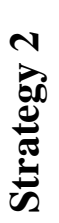 & 赵 & 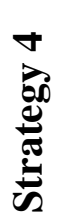 & 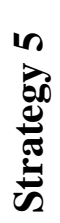 & 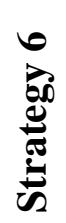 & 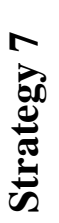 & 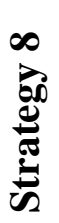 & 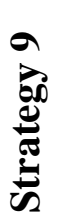 & 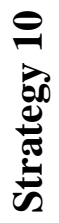 & 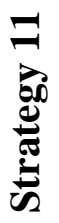 & 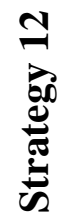 & 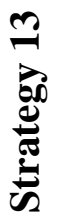 & 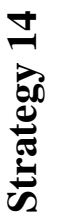 & 일 & 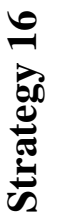 & 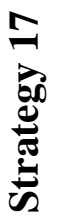 & 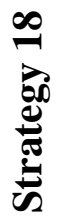 & 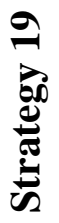 & 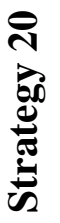 & 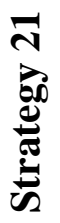 & 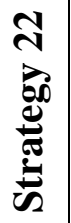 & 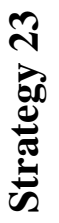 & 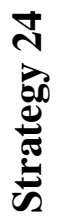 & 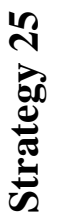 & 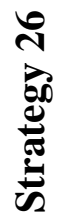 \\
\hline 36 & 1 & 0 & 0 & 0 & 0 & 0 & 0 & 0 & 0 & 0 & 0 & 0 & 0 & 0 & 0 & 0 & 0 & 0 & 0 & 0 & 0 & 0 & 0 & 0 & 0 & 0 \\
\hline 37 & 1 & 0 & 0 & 0 & 0 & 0 & 0 & 0 & 0 & 1 & 0 & 0 & 0 & 0 & 0 & 0 & 0 & 0 & 0 & 0 & 0 & 0 & 0 & 0 & 0 & 0 \\
\hline 38 & 0 & 0 & 1 & 0 & 0 & 1 & 0 & 0 & 0 & 1 & 0 & 1 & 0 & 0 & 0 & 1 & 0 & 0 & 0 & 0 & 0 & 0 & 0 & 0 & 0 & 0 \\
\hline 40 & 1 & 0 & 0 & 0 & 0 & 0 & 0 & 0 & 1 & 0 & 0 & 0 & 0 & 0 & 0 & 0 & 0 & 0 & 0 & 0 & 0 & 0 & 0 & 0 & 0 & 0 \\
\hline 42 & 0 & 0 & 0 & 0 & 0 & 0 & 0 & 0 & 0 & 0 & 0 & 1 & 0 & 0 & 0 & 0 & 0 & 0 & 0 & 0 & 0 & 0 & 0 & 0 & 0 & 0 \\
\hline 44 & 0 & 0 & 1 & 0 & 0 & 1 & 0 & 0 & 1 & 1 & 0 & 0 & 0 & 0 & 0 & 0 & 0 & 0 & 0 & 0 & 0 & 0 & 0 & 0 & 0 & 0 \\
\hline 46 & 1 & 0 & 0 & 0 & 0 & 1 & 1 & 0 & 0 & 0 & 0 & 0 & 0 & 0 & 0 & 0 & 0 & 0 & 0 & 0 & 0 & 0 & 0 & 0 & 0 & 0 \\
\hline 47 & 0 & 0 & 0 & 0 & 0 & 0 & 0 & 0 & 0 & 1 & 0 & 0 & 0 & 0 & 0 & 0 & 0 & 0 & 0 & 0 & 0 & 0 & 0 & 0 & 0 & 0 \\
\hline 48 & 0 & 0 & 0 & 0 & 0 & 0 & 0 & 0 & 1 & 1 & 0 & 0 & 0 & 0 & 0 & 0 & 0 & 0 & 0 & 0 & 0 & 0 & 0 & 0 & 0 & 0 \\
\hline 49 & 0 & 0 & 1 & 0 & 0 & 0 & 0 & 0 & 0 & 0 & 0 & 0 & 0 & 1 & 0 & 0 & 1 & 0 & 0 & 0 & 0 & 0 & 0 & 0 & 0 & 0 \\
\hline 50 & 0 & 0 & 0 & 0 & 0 & 1 & 0 & 0 & 1 & 0 & 0 & 0 & 0 & 0 & 0 & 0 & 0 & 0 & 0 & 0 & 0 & 1 & 0 & 0 & 0 & 0 \\
\hline 51 & 0 & 0 & 0 & 0 & 0 & 1 & 0 & 0 & 0 & 0 & 0 & 0 & 0 & 0 & 0 & 0 & 0 & 0 & 0 & 0 & 1 & 0 & 0 & 0 & 0 & 0 \\
\hline 53 & 0 & 0 & 0 & 0 & 0 & 1 & 0 & 0 & 0 & 0 & 0 & 0 & 0 & 0 & 0 & 0 & 0 & 0 & 0 & 0 & 0 & 0 & 0 & 0 & 0 & 1 \\
\hline 54 & 0 & 0 & 0 & 0 & 0 & 0 & 0 & 0 & 0 & 0 & 1 & 0 & 0 & 1 & 0 & 0 & 0 & 0 & 0 & 0 & 0 & 0 & 0 & 0 & 0 & 0 \\
\hline 55 & 1 & 0 & 1 & 0 & 0 & 1 & 0 & 0 & 0 & 0 & 0 & 0 & 0 & 0 & 0 & 0 & 0 & 0 & 0 & 0 & 0 & 0 & 0 & 0 & 0 & 0 \\
\hline 56 & 1 & 0 & 0 & 0 & 0 & 1 & 0 & 0 & 0 & 0 & 1 & 0 & 0 & 0 & 0 & 0 & 0 & 0 & 0 & 0 & 0 & 0 & 0 & 0 & 0 & 0 \\
\hline 57 & 1 & 0 & 1 & 0 & 0 & 0 & 0 & 0 & 0 & 0 & 0 & 0 & 0 & 0 & 0 & 0 & 0 & 0 & 0 & 0 & 0 & 0 & 0 & 0 & 0 & 0 \\
\hline 59 & 0 & 0 & 0 & 0 & 0 & 0 & 0 & 0 & 0 & 0 & 0 & 1 & 0 & 0 & 0 & 0 & 0 & 0 & 0 & 0 & 0 & 0 & 0 & 0 & 0 & 0 \\
\hline 60 & 1 & 0 & 0 & 0 & 0 & 0 & 0 & 0 & 0 & 0 & 0 & 0 & 0 & 0 & 0 & 0 & 0 & 0 & 0 & 0 & 0 & 0 & 0 & 0 & 0 & 0 \\
\hline 62 & 1 & 0 & 1 & 0 & 0 & 0 & 0 & 0 & 0 & 0 & 0 & 0 & 0 & 0 & 0 & 0 & 0 & 0 & 0 & 0 & 0 & 0 & 0 & 0 & 0 & 0 \\
\hline 64 & 1 & 0 & 0 & 0 & 0 & 0 & 0 & 0 & 0 & 0 & 0 & 1 & 0 & 0 & 0 & 0 & 0 & 0 & 0 & 0 & 0 & 0 & 0 & 0 & 0 & 0 \\
\hline 66 & 1 & 0 & 0 & 0 & 0 & 0 & 0 & 0 & 0 & 0 & 0 & 0 & 0 & 0 & 0 & 0 & 0 & 0 & 0 & 0 & 0 & 0 & 0 & 0 & 0 & 0 \\
\hline 68 & 0 & 0 & 1 & 0 & 0 & 0 & 0 & 0 & 0 & 0 & 0 & 0 & 0 & 0 & 0 & 0 & 0 & 0 & 0 & 0 & 0 & 0 & 0 & 0 & 0 & 0 \\
\hline 69 & 1 & 0 & 0 & 0 & 0 & 0 & 0 & 0 & 1 & 1 & 0 & 0 & 0 & 0 & 0 & 0 & 0 & 0 & 0 & 0 & 0 & 0 & 0 & 0 & 0 & 0 \\
\hline 70 & 0 & 0 & 1 & 0 & 0 & 0 & 0 & 0 & 0 & 1 & 0 & 0 & 0 & 0 & 0 & 0 & 0 & 0 & 0 & 0 & 0 & 0 & 0 & 0 & 0 & 0 \\
\hline$\%$ & 45 & 4 & 39 & 4 & 4 & 22 & 4 & 8 & 27 & 22 & 8 & 10 & 2 & 6 & 0 & 2 & 4 & 0 & 0 & 4 & 2 & 8 & 2 & 0 & 0 & 10 \\
\hline
\end{tabular}


Sample Results from the Interrespondent Matrix - Analyses of Participants' Choice of Strategies per Indicator (continued)

Strategies Present in Indicator 2: 60 Responses of 63 Possible Open-Ended Responses

\begin{tabular}{|c|c|c|c|c|c|c|c|c|c|c|c|c|c|c|c|c|c|c|c|c|c|c|c|c|c|c|}
\hline 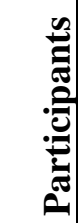 & 엄 & 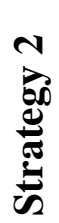 & 赵 & 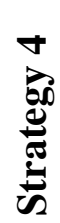 & م) & 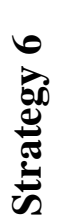 & Ðే & 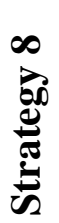 & क્ & 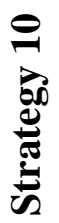 & 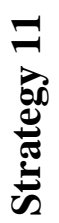 & 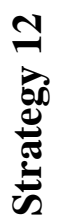 & 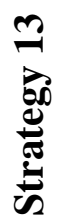 & 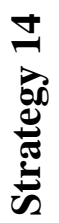 & ڤ్ర & 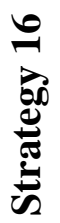 & 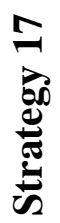 & 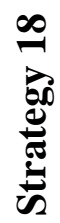 & 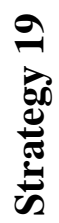 & 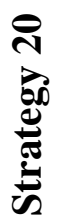 & 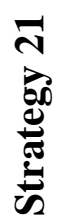 & 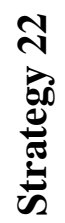 & 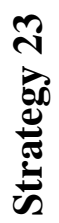 & 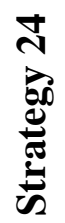 & 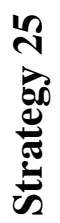 & 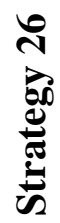 \\
\hline 1 & 1 & 0 & 0 & 0 & 0 & 1 & 0 & 0 & 0 & 0 & 0 & 0 & 0 & 0 & 0 & 0 & 0 & 0 & 0 & 1 & 0 & 0 & 0 & 0 & 0 & 0 \\
\hline 2 & 1 & 0 & 1 & 0 & 0 & 0 & 0 & 0 & 1 & 1 & 0 & 0 & 0 & 0 & 0 & 0 & 0 & 0 & 0 & 0 & 0 & 0 & 0 & 0 & 0 & 0 \\
\hline 3 & 1 & 1 & 1 & 0 & 0 & 0 & 0 & 0 & 1 & 0 & 0 & 0 & 0 & 0 & 0 & 0 & 0 & 0 & 0 & 0 & 0 & 0 & 0 & 0 & 0 & 0 \\
\hline 4 & 0 & 0 & 1 & 0 & 0 & 0 & 0 & 0 & 0 & 0 & 1 & 0 & 0 & 0 & 0 & 0 & 0 & 0 & 0 & 0 & 0 & 0 & 1 & 0 & 0 & 0 \\
\hline 6 & 1 & 0 & 1 & 0 & 0 & 0 & 0 & 0 & 0 & 0 & 0 & 0 & 0 & 0 & 0 & 0 & 0 & 0 & 0 & 0 & 0 & 0 & 0 & 0 & 0 & 0 \\
\hline 7 & 1 & 0 & 0 & 0 & 0 & 0 & 0 & 0 & 0 & 0 & 0 & 0 & 0 & 0 & 0 & 0 & 1 & 0 & 0 & 0 & 0 & 0 & 0 & 0 & 0 & 0 \\
\hline 8 & 0 & 0 & 0 & 0 & 0 & 0 & 1 & 0 & 1 & 0 & 0 & 0 & 0 & 0 & 0 & 0 & 0 & 0 & 0 & 0 & 0 & 0 & 0 & 0 & 0 & 0 \\
\hline 9 & 0 & 0 & 1 & 0 & 0 & 0 & 0 & 0 & 1 & 0 & 0 & 0 & 0 & 0 & 0 & 0 & 0 & 0 & 0 & 0 & 0 & 0 & 0 & 0 & 0 & 1 \\
\hline 10 & 0 & 1 & 1 & 0 & 0 & 1 & 0 & 0 & 1 & 0 & 0 & 0 & 0 & 0 & 0 & 0 & 0 & 0 & 0 & 0 & 0 & 0 & 0 & 0 & 0 & 1 \\
\hline 11 & 1 & 1 & 0 & 0 & 1 & 0 & 1 & 0 & 0 & 0 & 0 & 0 & 0 & 0 & 0 & 0 & 0 & 0 & 0 & 0 & 0 & 0 & 0 & 0 & 0 & 0 \\
\hline 12 & 1 & 0 & 1 & 0 & 0 & 0 & 0 & 0 & 0 & 0 & 0 & 0 & 0 & 0 & 0 & 0 & 0 & 0 & 0 & 0 & 0 & 0 & 0 & 0 & 0 & 0 \\
\hline 13 & 1 & 0 & 1 & 0 & 0 & 1 & 0 & 1 & 0 & 0 & 0 & 0 & 0 & 0 & 0 & 0 & 0 & 0 & 0 & 0 & 0 & 0 & 0 & 0 & 0 & 0 \\
\hline 15 & 0 & 0 & 0 & 0 & 0 & 0 & 0 & 0 & 1 & 0 & 0 & 0 & 0 & 1 & 0 & 0 & 0 & 0 & 0 & 0 & 0 & 0 & 0 & 0 & 0 & 0 \\
\hline 16 & 0 & 0 & 0 & 0 & 0 & 0 & 0 & 0 & 1 & 0 & 0 & 0 & 0 & 0 & 0 & 0 & 0 & 0 & 0 & 0 & 0 & 0 & 0 & 0 & 0 & 1 \\
\hline 17 & 0 & 0 & 0 & 0 & 0 & 0 & 0 & 0 & 1 & 0 & 0 & 0 & 0 & 0 & 0 & 0 & 0 & 0 & 0 & 0 & 0 & 0 & 0 & 0 & 0 & 0 \\
\hline 18 & 0 & 0 & 0 & 0 & 1 & 0 & 0 & 0 & 0 & 0 & 0 & 0 & 0 & 0 & 0 & 0 & 0 & 0 & 0 & 0 & 0 & 0 & 0 & 0 & 0 & 0 \\
\hline 19 & 0 & 0 & 1 & 0 & 0 & 0 & 0 & 0 & 1 & 0 & 0 & 0 & 0 & 0 & 0 & 0 & 0 & 0 & 0 & 0 & 0 & 1 & 0 & 0 & 0 & 0 \\
\hline 20 & 0 & 0 & 1 & 1 & 0 & 1 & 0 & 1 & 0 & 0 & 0 & 0 & 0 & 0 & 0 & 0 & 0 & 0 & 0 & 0 & 0 & 0 & 0 & 0 & 0 & 0 \\
\hline 21 & 1 & 0 & 0 & 0 & 0 & 1 & 0 & 0 & 0 & 0 & 0 & 0 & 0 & 0 & 0 & 0 & 0 & 0 & 0 & 0 & 0 & 0 & 0 & 0 & 0 & 0 \\
\hline 22 & 1 & 0 & 0 & 0 & 0 & 1 & 0 & 1 & 1 & 0 & 0 & 0 & 0 & 0 & 0 & 0 & 1 & 1 & 0 & 0 & 1 & 0 & 0 & 0 & 0 & 1 \\
\hline 23 & 1 & 0 & 0 & 0 & 0 & 0 & 0 & 0 & 0 & 0 & 0 & 0 & 0 & 0 & 0 & 0 & 0 & 0 & 0 & 0 & 0 & 0 & 0 & 0 & 0 & 0 \\
\hline 25 & 0 & 0 & 0 & 0 & 0 & 0 & 0 & 0 & 1 & 0 & 0 & 0 & 0 & 0 & 0 & 0 & 0 & 0 & 0 & 0 & 0 & 0 & 0 & 0 & 0 & 0 \\
\hline 26 & 1 & 0 & 0 & 0 & 1 & 0 & 0 & 1 & 0 & 0 & 0 & 0 & 0 & 0 & 0 & 0 & 0 & 0 & 0 & 0 & 0 & 0 & 0 & 0 & 0 & 0 \\
\hline 27 & 0 & 0 & 0 & 0 & 0 & 0 & 0 & 0 & 1 & 0 & 0 & 0 & 0 & 0 & 0 & 0 & 0 & 0 & 0 & 0 & 0 & 0 & 0 & 0 & 0 & 1 \\
\hline 28 & 0 & 0 & 1 & 0 & 0 & 0 & 0 & 0 & 1 & 0 & 0 & 0 & 0 & 0 & 0 & 0 & 0 & 0 & 0 & 0 & 0 & 0 & 0 & 0 & 0 & 1 \\
\hline 29 & 0 & 0 & 0 & 0 & 0 & 1 & 0 & 0 & 0 & 0 & 0 & 0 & 0 & 0 & 0 & 0 & 0 & 0 & 0 & 0 & 0 & 0 & 0 & 0 & 0 & 0 \\
\hline
\end{tabular}


Sample Results from the Interrespondent Matrix - Analyses of Participants' Choice of Strategies per Indicator (continued)

Strategies Present in Indicator 2: 60 Responses of 63 Possible Open-Ended Responses

\begin{tabular}{|c|c|c|c|c|c|c|c|c|c|c|c|c|c|c|c|c|c|c|c|c|c|c|c|c|c|c|}
\hline 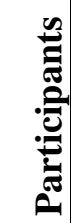 & 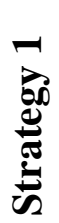 & 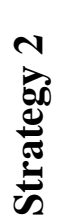 & 赵 & 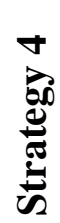 & م) & 苞 & 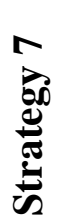 & 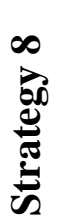 & 疋 & 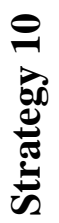 & 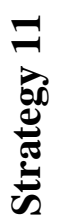 & 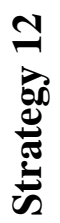 & 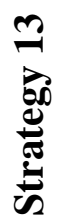 & 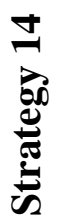 & ڤ్ర & 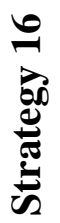 & 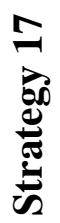 & 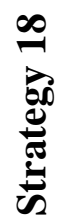 & 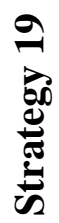 & 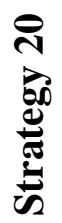 & 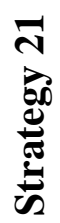 & 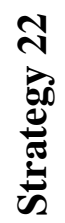 & 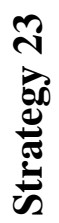 & 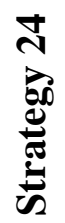 & 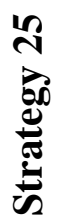 & 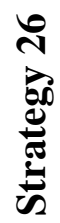 \\
\hline 31 & 0 & 0 & 0 & 0 & 0 & 1 & 0 & 0 & 0 & 0 & 0 & 0 & 0 & 1 & 0 & 0 & 0 & 0 & 0 & 0 & 0 & 0 & 0 & 0 & 0 & 0 \\
\hline 32 & 0 & 0 & 1 & 0 & 0 & 0 & 0 & 0 & 1 & 0 & 0 & 0 & 0 & 0 & 0 & 0 & 0 & 0 & 0 & 0 & 0 & 0 & 0 & 0 & 0 & 1 \\
\hline 33 & 0 & 0 & 0 & 0 & 0 & 0 & 0 & 0 & 0 & 0 & 0 & 0 & 0 & 1 & 0 & 0 & 0 & 0 & 0 & 0 & 0 & 0 & 0 & 0 & 0 & 0 \\
\hline 34 & 1 & 0 & 1 & 0 & 0 & 0 & 0 & 0 & 1 & 0 & 0 & 1 & 0 & 0 & 0 & 0 & 0 & 0 & 0 & 0 & 0 & 0 & 0 & 0 & 0 & 0 \\
\hline 35 & 0 & 1 & 0 & 0 & 0 & 0 & 0 & 0 & 0 & 0 & 0 & 0 & 0 & 0 & 0 & 0 & 0 & 0 & 0 & 0 & 0 & 0 & 0 & 0 & 0 & 0 \\
\hline 36 & 1 & 0 & 0 & 0 & 0 & 0 & 0 & 0 & 1 & 0 & 0 & 0 & 0 & 0 & 0 & 0 & 0 & 0 & 0 & 0 & 0 & 0 & 0 & 0 & 0 & 0 \\
\hline 37 & 1 & 0 & 0 & 0 & 0 & 0 & 0 & 0 & 1 & 0 & 0 & 0 & 0 & 0 & 0 & 0 & 0 & 0 & 0 & 0 & 0 & 0 & 0 & 0 & 0 & 0 \\
\hline 38 & 0 & 0 & 0 & 0 & 0 & 1 & 0 & 0 & 0 & 0 & 0 & 0 & 0 & 0 & 0 & 0 & 0 & 0 & 0 & 0 & 0 & 0 & 0 & 0 & 0 & 0 \\
\hline 40 & 0 & 0 & 0 & 0 & 0 & 0 & 0 & 0 & 1 & 0 & 0 & 0 & 0 & 0 & 0 & 0 & 0 & 0 & 0 & 0 & 0 & 0 & 0 & 0 & 0 & 0 \\
\hline 41 & 0 & 0 & 0 & 0 & 0 & 0 & 0 & 1 & 0 & 0 & 0 & 0 & 0 & 0 & 0 & 0 & 0 & 0 & 0 & 0 & 0 & 0 & 0 & 0 & 0 & 0 \\
\hline 42 & 0 & 0 & 0 & 0 & 0 & 0 & 0 & 0 & 1 & 0 & 0 & 0 & 0 & 1 & 0 & 0 & 0 & 0 & 0 & 0 & 0 & 0 & 0 & 0 & 0 & 0 \\
\hline 45 & 1 & 0 & 0 & 0 & 0 & 0 & 0 & 0 & 0 & 0 & 0 & 0 & 0 & 0 & 0 & 0 & 0 & 0 & 0 & 0 & 0 & 0 & 0 & 0 & 0 & 0 \\
\hline 46 & 1 & 0 & 0 & 0 & 0 & 0 & 1 & 0 & 0 & 0 & 0 & 0 & 0 & 0 & 0 & 0 & 0 & 0 & 0 & 0 & 0 & 0 & 0 & 0 & 0 & 0 \\
\hline 47 & 0 & 0 & 0 & 0 & 0 & 0 & 0 & 0 & 0 & 0 & 1 & 0 & 0 & 1 & 0 & 0 & 0 & 0 & 0 & 0 & 0 & 0 & 0 & 0 & 0 & 0 \\
\hline 48 & 0 & 0 & 0 & 0 & 0 & 0 & 0 & 0 & 0 & 0 & 0 & 0 & 0 & 1 & 0 & 0 & 0 & 0 & 0 & 0 & 0 & 0 & 0 & 0 & 0 & 0 \\
\hline 49 & 0 & 0 & 1 & 0 & 0 & 0 & 0 & 0 & 0 & 0 & 0 & 0 & 0 & 1 & 0 & 0 & 1 & 0 & 0 & 0 & 0 & 0 & 0 & 0 & 0 & 0 \\
\hline 50 & 1 & 0 & 0 & 0 & 0 & 0 & 0 & 0 & 0 & 0 & 0 & 0 & 1 & 0 & 0 & 0 & 0 & 0 & 0 & 0 & 0 & 0 & 0 & 0 & 0 & 0 \\
\hline 51 & 0 & 0 & 0 & 0 & 0 & 1 & 0 & 0 & 0 & 0 & 0 & 0 & 0 & 0 & 0 & 0 & 0 & 0 & 0 & 0 & 1 & 0 & 0 & 0 & 0 & 0 \\
\hline 52 & 0 & 0 & 0 & 0 & 1 & 0 & 0 & 1 & 0 & 0 & 1 & 0 & 0 & 0 & 0 & 0 & 0 & 0 & 0 & 0 & 0 & 0 & 0 & 0 & 0 & 0 \\
\hline 53 & 0 & 0 & 0 & 0 & 0 & 1 & 0 & 0 & 0 & 0 & 0 & 0 & 0 & 0 & 0 & 0 & 0 & 0 & 0 & 0 & 0 & 0 & 0 & 0 & 0 & 1 \\
\hline 54 & 0 & 0 & 0 & 0 & 0 & 0 & 0 & 0 & 0 & 0 & 1 & 0 & 0 & 1 & 0 & 0 & 0 & 0 & 0 & 0 & 0 & 0 & 0 & 0 & 0 & 0 \\
\hline 55 & 0 & 0 & 1 & 0 & 0 & 0 & 0 & 0 & 0 & 0 & 0 & 0 & 0 & 0 & 0 & 0 & 0 & 0 & 0 & 1 & 0 & 0 & 0 & 0 & 0 & 0 \\
\hline 56 & 1 & 0 & 0 & 0 & 0 & 1 & 0 & 0 & 0 & 0 & 1 & 0 & 0 & 0 & 0 & 0 & 0 & 0 & 0 & 0 & 0 & 0 & 0 & 0 & 0 & 0 \\
\hline 57 & 0 & 0 & 0 & 0 & 0 & 0 & 0 & 0 & 1 & 0 & 0 & 0 & 0 & 0 & 0 & 0 & 0 & 0 & 0 & 0 & 0 & 0 & 0 & 0 & 0 & 0 \\
\hline 59 & 0 & 0 & 1 & 0 & 0 & 0 & 0 & 0 & 1 & 0 & 0 & 0 & 0 & 0 & 0 & 0 & 0 & 0 & 0 & 0 & 0 & 0 & 0 & 0 & 0 & 1 \\
\hline 60 & 1 & 0 & 0 & 0 & 0 & 0 & 0 & 0 & 0 & 0 & 0 & 0 & 0 & 0 & 0 & 0 & 0 & 0 & 0 & 0 & 0 & 0 & 0 & 0 & 0 & 0 \\
\hline
\end{tabular}


Sample Results from the Interrespondent Matrix - Analyses of Participants' Choice of Strategies per Indicator (continued)

Strategies Present in Indicator 2: 60 Responses of 63 Possible Open-Ended Responses (continued)

\begin{tabular}{|c|c|c|c|c|c|c|c|c|c|c|c|c|c|c|c|c|c|c|c|c|c|c|c|c|c|c|}
\hline 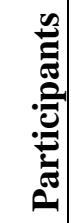 & 常 & 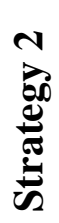 & 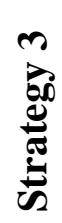 & 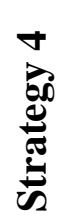 & م & م) & 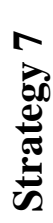 & 矛 & 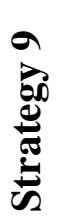 & 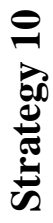 & 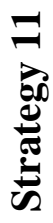 & 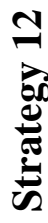 & 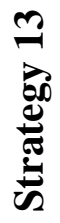 & 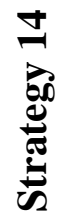 & م & مَّ & స్ & & 奈 & 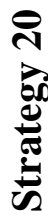 & 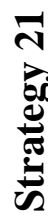 & 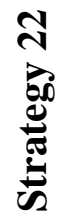 & 光 & 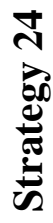 & 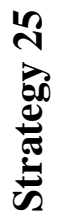 & 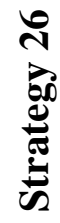 \\
\hline 62 & 1 & 0 & 0 & 0 & 0 & 0 & 0 & 0 & 0 & 0 & 0 & 0 & 0 & 0 & 0 & 0 & 0 & 0 & 0 & 0 & 0 & 0 & 0 & 0 & 0 & 0 \\
\hline 63 & 0 & 0 & 1 & 0 & 0 & 0 & 0 & 0 & 1 & 0 & 0 & 0 & 0 & 0 & 0 & 0 & 0 & 0 & 0 & 0 & 1 & 0 & 0 & 0 & 0 & 0 \\
\hline 64 & 1 & 0 & 0 & 0 & 1 & 1 & 0 & 0 & 0 & 0 & 0 & 1 & 0 & 0 & 0 & 0 & 0 & 0 & 0 & 0 & 0 & 0 & 0 & 0 & 0 & 0 \\
\hline 66 & 0 & 0 & 1 & 0 & 0 & 0 & 0 & 0 & 0 & 0 & 0 & 0 & 0 & 0 & 0 & 0 & 0 & 0 & 0 & 0 & 0 & 0 & 0 & 0 & 0 & 0 \\
\hline 67 & 1 & 0 & 0 & 0 & 0 & 0 & 0 & 0 & 1 & 0 & 0 & 0 & 0 & 0 & 0 & 0 & 0 & 0 & 0 & 0 & 0 & 0 & 0 & 0 & 0 & 0 \\
\hline 68 & 1 & 0 & 0 & 0 & 0 & 0 & 0 & 0 & 0 & 0 & 0 & 0 & 0 & 0 & 0 & 0 & 0 & 0 & 0 & 0 & 0 & 0 & 0 & 0 & 0 & 0 \\
\hline 69 & 1 & 0 & 0 & 0 & 0 & 0 & 0 & 0 & 1 & 1 & 0 & 0 & 0 & 1 & 0 & 0 & 0 & 0 & 0 & 0 & 0 & 0 & 0 & 0 & 0 & 0 \\
\hline 70 & 0 & 0 & 0 & 0 & 0 & 0 & 0 & 0 & 1 & 0 & 0 & 0 & 0 & 1 & 0 & 0 & 0 & 0 & 0 & 0 & 0 & 0 & 0 & 0 & 0 & 0 \\
\hline$\%$ & 42 & 7 & 30 & 2 & 8 & 22 & 5 & 10 & 42 & 3 & 8 & 3 & 2 & 17 & 0 & 0 & 5 & 2 & 0 & 3 & 5 & 2 & 2 & 0 & 0 & 15 \\
\hline
\end{tabular}


Sample Results from the Interrespondent Matrix - Analyses of Participants' Choice of Strategies per Indicator (continued)

Strategies Present in Indicator 3: 56 Responses of 63 Possible Open-Ended Responses

\begin{tabular}{|c|c|c|c|c|c|c|c|c|c|c|c|c|c|c|c|c|c|c|c|c|c|c|c|c|c|c|}
\hline 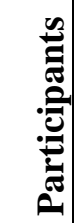 & 홍 & 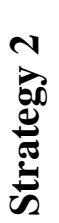 & m & 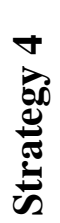 & م્ & 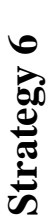 & 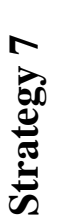 & 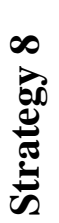 & 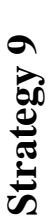 & 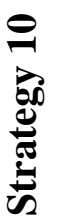 & 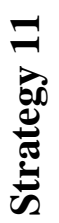 & 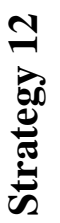 & 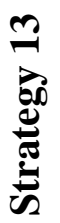 & 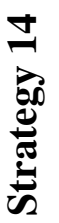 & 号 & 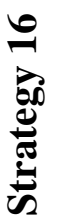 & 공 & 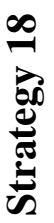 & 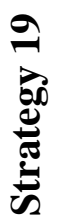 & 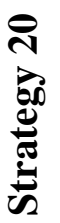 & 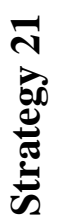 & 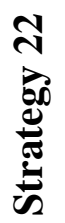 & 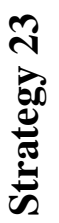 & 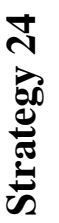 & 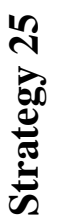 & 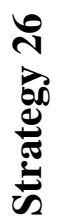 \\
\hline 1 & 1 & 0 & 0 & 0 & 0 & 0 & 0 & 0 & 0 & 0 & 0 & 0 & 0 & 0 & 0 & 0 & 0 & 0 & 0 & 0 & 0 & 0 & 0 & 0 & 0 & 0 \\
\hline 2 & 0 & 0 & 0 & 0 & 0 & 0 & 0 & 0 & 0 & 0 & 0 & 0 & 0 & 0 & 0 & 0 & 0 & 0 & 0 & 0 & 0 & 0 & 0 & 0 & 0 & 0 \\
\hline 4 & 0 & 0 & 0 & 0 & 0 & 0 & 0 & 1 & 1 & 0 & 0 & 0 & 0 & 0 & 0 & 0 & 0 & 0 & 0 & 0 & 0 & 0 & 0 & 0 & 0 & 0 \\
\hline 6 & 1 & 1 & 1 & 0 & 0 & 0 & 0 & 0 & 0 & 0 & 0 & 0 & 0 & 0 & 0 & 0 & 0 & 0 & 0 & 0 & 0 & 0 & 0 & 0 & 0 & 0 \\
\hline 7 & 0 & 0 & 1 & 0 & 0 & 0 & 0 & 0 & 0 & 0 & 0 & 0 & 0 & 0 & 0 & 1 & 0 & 0 & 0 & 0 & 0 & 1 & 0 & 0 & 0 & 0 \\
\hline 8 & 0 & 0 & 0 & 0 & 0 & 0 & 0 & 0 & 1 & 0 & 0 & 0 & 0 & 0 & 0 & 0 & 0 & 0 & 0 & 0 & 0 & 0 & 0 & 0 & 0 & 1 \\
\hline 9 & 0 & 0 & 1 & 0 & 0 & 0 & 0 & 0 & 1 & 0 & 0 & 0 & 0 & 0 & 0 & 0 & 0 & 0 & 0 & 0 & 0 & 0 & 0 & 0 & 0 & 0 \\
\hline 10 & 0 & 0 & 1 & 0 & 0 & 1 & 0 & 0 & 1 & 0 & 0 & 0 & 0 & 0 & 0 & 0 & 0 & 0 & 0 & 0 & 0 & 0 & 0 & 0 & 0 & 1 \\
\hline 11 & 0 & 1 & 0 & 0 & 1 & 0 & 1 & 0 & 0 & 0 & 1 & 1 & 0 & 0 & 0 & 0 & 0 & 0 & 0 & 0 & 0 & 0 & 0 & 0 & 0 & 0 \\
\hline 13 & 1 & 0 & 1 & 0 & 1 & 1 & 0 & 1 & 0 & 0 & 0 & 0 & 0 & 0 & 0 & 0 & 0 & 0 & 0 & 0 & 0 & 0 & 0 & 0 & 0 & 0 \\
\hline 15 & 0 & 0 & 0 & 0 & 0 & 0 & 0 & 0 & 1 & 0 & 0 & 0 & 0 & 0 & 0 & 0 & 0 & 0 & 0 & 0 & 0 & 0 & 0 & 0 & 0 & 0 \\
\hline 16 & 0 & 0 & 0 & 0 & 0 & 1 & 0 & 0 & 1 & 0 & 0 & 0 & 0 & 0 & 0 & 0 & 0 & 0 & 0 & 0 & 0 & 0 & 0 & 0 & 0 & 0 \\
\hline 18 & 0 & 0 & 0 & 0 & 1 & 0 & 0 & 0 & 0 & 0 & 0 & 0 & 0 & 0 & 0 & 0 & 0 & 0 & 0 & 0 & 0 & 0 & 0 & 0 & 0 & 0 \\
\hline 19 & 0 & 0 & 1 & 0 & 0 & 0 & 0 & 0 & 1 & 0 & 0 & 0 & 0 & 0 & 0 & 0 & 0 & 0 & 0 & 0 & 0 & 1 & 0 & 0 & 0 & 0 \\
\hline 20 & 0 & 0 & 1 & 1 & 0 & 1 & 0 & 1 & 0 & 0 & 0 & 0 & 0 & 0 & 0 & 0 & 0 & 0 & 0 & 0 & 0 & 0 & 0 & 0 & 0 & 0 \\
\hline 21 & 0 & 0 & 0 & 0 & 0 & 0 & 0 & 0 & 1 & 0 & 0 & 0 & 0 & 1 & 0 & 0 & 0 & 0 & 0 & 0 & 0 & 0 & 0 & 0 & 0 & 0 \\
\hline 22 & 1 & 0 & 0 & 0 & 0 & 1 & 0 & 1 & 1 & 0 & 0 & 0 & 0 & 0 & 0 & 0 & 1 & 1 & 0 & 0 & 1 & 0 & 0 & 0 & 0 & 0 \\
\hline 23 & 0 & 0 & 0 & 0 & 0 & 0 & 0 & 0 & 0 & 0 & 0 & 0 & 0 & 0 & 0 & 0 & 0 & 0 & 0 & 0 & 0 & 0 & 0 & 0 & 0 & 0 \\
\hline 25 & 0 & 0 & 0 & 0 & 0 & 0 & 0 & 0 & 1 & 0 & 0 & 0 & 0 & 0 & 0 & 0 & 0 & 0 & 0 & 0 & 0 & 0 & 0 & 0 & 0 & 0 \\
\hline 26 & 0 & 0 & 0 & 0 & 1 & 0 & 0 & 1 & 0 & 0 & 0 & 0 & 0 & 0 & 0 & 0 & 0 & 0 & 0 & 0 & 0 & 0 & 0 & 0 & 0 & 0 \\
\hline 27 & 0 & 0 & 0 & 0 & 0 & 0 & 0 & 0 & 1 & 0 & 0 & 0 & 0 & 0 & 0 & 0 & 0 & 0 & 0 & 0 & 0 & 0 & 0 & 0 & 0 & 1 \\
\hline 28 & 0 & 0 & 1 & 0 & 0 & 0 & 0 & 0 & 1 & 0 & 0 & 0 & 0 & 1 & 0 & 0 & 0 & 0 & 0 & 0 & 0 & 0 & 0 & 0 & 0 & 1 \\
\hline 29 & 1 & 0 & 0 & 0 & 0 & 0 & 0 & 0 & 0 & 0 & 0 & 0 & 1 & 0 & 0 & 0 & 0 & 0 & 0 & 0 & 0 & 0 & 0 & 0 & 0 & 0 \\
\hline 30 & 0 & 0 & 0 & 0 & 0 & 0 & 0 & 0 & 1 & 0 & 0 & 0 & 0 & 0 & 0 & 0 & 0 & 0 & 0 & 0 & 0 & 0 & 0 & 0 & 0 & 0 \\
\hline 31 & 0 & 0 & 0 & 0 & 0 & 0 & 0 & 0 & 1 & 0 & 0 & 0 & 1 & 0 & 0 & 0 & 0 & 0 & 0 & 0 & 0 & 0 & 0 & 0 & 0 & 0 \\
\hline 32 & 0 & 0 & 1 & 0 & 0 & 1 & 0 & 0 & 1 & 0 & 0 & 0 & 0 & 0 & 0 & 0 & 0 & 0 & 0 & 0 & 0 & 0 & 0 & 0 & 0 & 0 \\
\hline
\end{tabular}


Sample Results from the Interrespondent Matrix - Analyses of Participants' Choice of Strategies per Indicator (continued)

Strategies Present in Indicator 3: 56 Responses of 63 Possible Open-Ended Responses (continued)

\begin{tabular}{|c|c|c|c|c|c|c|c|c|c|c|c|c|c|c|c|c|c|c|c|c|c|c|c|c|c|c|}
\hline 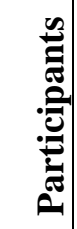 & 党 & 胥 & 趈 & 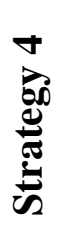 & 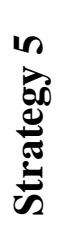 & 范 & 宽 & 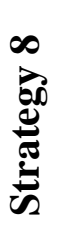 & 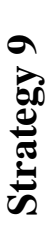 & 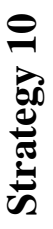 & 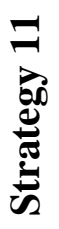 & 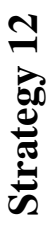 & 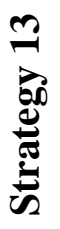 & 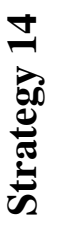 & 号 & 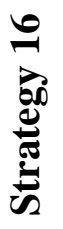 & 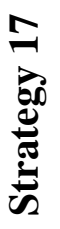 & 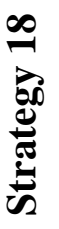 & 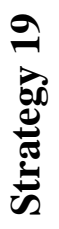 & 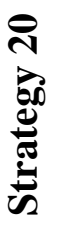 & 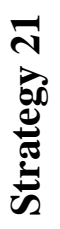 & 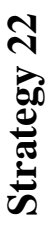 & 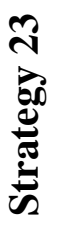 & 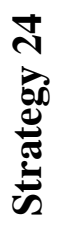 & 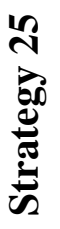 & 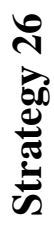 \\
\hline 33 & 0 & 0 & 0 & 0 & 0 & 0 & 0 & 0 & 0 & 0 & 0 & 0 & 0 & 1 & 0 & 0 & 0 & 0 & 0 & 0 & 0 & 0 & 0 & 0 & 0 & 0 \\
\hline 34 & 0 & 0 & 0 & 0 & 0 & 0 & 0 & 0 & 0 & 0 & 0 & 0 & 0 & 1 & 0 & 0 & 0 & 0 & 0 & 0 & 0 & 0 & 0 & 0 & 0 & 0 \\
\hline 35 & 0 & 0 & 0 & 0 & 0 & 0 & 0 & 0 & 0 & 0 & 0 & 0 & 0 & 0 & 0 & 0 & 1 & 0 & 0 & 0 & 1 & 0 & 0 & 0 & 0 & 0 \\
\hline 36 & 0 & 0 & 0 & 0 & 0 & 0 & 0 & 0 & 1 & 0 & 0 & 0 & 0 & 0 & 0 & 0 & 0 & 0 & 0 & 0 & 0 & 0 & 0 & 0 & 0 & 0 \\
\hline 37 & 0 & 0 & 0 & 0 & 0 & 0 & 0 & 0 & 1 & 0 & 1 & 0 & 0 & 0 & 0 & 0 & 0 & 0 & 0 & 0 & 0 & 0 & 0 & 0 & 0 & 0 \\
\hline 38 & 0 & 0 & 0 & 0 & 0 & 1 & 0 & 0 & 1 & 0 & 0 & 0 & 0 & 0 & 0 & 0 & 0 & 0 & 0 & 0 & 0 & 0 & 0 & 0 & 0 & 0 \\
\hline 40 & 0 & 0 & 0 & 0 & 0 & 1 & 0 & 0 & 0 & 0 & 0 & 0 & 0 & 0 & 0 & 0 & 0 & 0 & 0 & 0 & 0 & 0 & 0 & 0 & 0 & 0 \\
\hline 41 & 0 & 0 & 0 & 0 & 0 & 1 & 0 & 0 & 0 & 0 & 0 & 0 & 0 & 0 & 0 & 0 & 0 & 0 & 0 & 0 & 0 & 0 & 0 & 0 & 0 & 0 \\
\hline 42 & 1 & 0 & 0 & 0 & 0 & 0 & 0 & 0 & 0 & 0 & 0 & 0 & 0 & 0 & 0 & 0 & 0 & 0 & 0 & 0 & 0 & 0 & 0 & 0 & 0 & 0 \\
\hline 44 & 0 & 0 & 0 & 0 & 0 & 0 & 0 & 0 & 1 & 1 & 0 & 0 & 0 & 0 & 0 & 0 & 0 & 0 & 0 & 0 & 1 & 0 & 1 & 0 & 0 & 1 \\
\hline 45 & 0 & 0 & 0 & 0 & 0 & 0 & 0 & 0 & 0 & 0 & 0 & 0 & 0 & 0 & 0 & 0 & 0 & 0 & 0 & 0 & 0 & 0 & 0 & 1 & 0 & 0 \\
\hline 46 & 1 & 0 & 0 & 0 & 0 & 0 & 1 & 0 & 0 & 0 & 0 & 0 & 0 & 0 & 0 & 0 & 0 & 0 & 0 & 0 & 0 & 0 & 0 & 0 & 0 & 0 \\
\hline 47 & 0 & 0 & 0 & 0 & 0 & 0 & 0 & 0 & 0 & 0 & 1 & 0 & 0 & 1 & 0 & 0 & 0 & 0 & 0 & 0 & 0 & 0 & 0 & 0 & 0 & 0 \\
\hline 48 & 0 & 0 & 0 & 0 & 0 & 0 & 0 & 0 & 0 & 0 & 0 & 0 & 0 & 1 & 0 & 0 & 0 & 0 & 0 & 0 & 0 & 0 & 0 & 0 & 0 & 0 \\
\hline 49 & 0 & 0 & 1 & 0 & 0 & 1 & 0 & 0 & 0 & 0 & 0 & 0 & 0 & 0 & 0 & 0 & 0 & 0 & 0 & 0 & 1 & 0 & 0 & 0 & 0 & 0 \\
\hline 50 & 0 & 0 & 0 & 0 & 1 & 0 & 0 & 0 & 1 & 0 & 0 & 1 & 0 & 0 & 0 & 0 & 0 & 0 & 0 & 0 & 0 & 0 & 0 & 0 & 0 & 0 \\
\hline 51 & 0 & 0 & 1 & 0 & 0 & 0 & 0 & 0 & 0 & 0 & 0 & 0 & 0 & 0 & 0 & 0 & 0 & 0 & 0 & 0 & 0 & 0 & 0 & 0 & 0 & 0 \\
\hline 52 & 0 & 0 & 0 & 0 & 1 & 0 & 0 & 1 & 0 & 0 & 1 & 0 & 0 & 0 & 0 & 0 & 0 & 0 & 0 & 0 & 0 & 0 & 0 & 0 & 0 & 0 \\
\hline 53 & 0 & 0 & 0 & 0 & 0 & 1 & 0 & 0 & 0 & 0 & 0 & 0 & 0 & 0 & 0 & 0 & 0 & 0 & 0 & 0 & 0 & 0 & 0 & 0 & 0 & 1 \\
\hline 54 & 0 & 0 & 0 & 0 & 0 & 0 & 0 & 0 & 0 & 0 & 1 & 0 & 0 & 1 & 0 & 0 & 0 & 0 & 0 & 0 & 0 & 0 & 0 & 0 & 0 & 0 \\
\hline 57 & 0 & 0 & 0 & 0 & 0 & 0 & 0 & 0 & 1 & 0 & 0 & 0 & 0 & 0 & 0 & 0 & 0 & 0 & 1 & 0 & 0 & 0 & 0 & 0 & 0 & 0 \\
\hline 59 & 0 & 0 & 0 & 0 & 1 & 0 & 0 & 0 & 0 & 0 & 0 & 0 & 0 & 0 & 0 & 0 & 0 & 0 & 0 & 0 & 0 & 0 & 0 & 0 & 0 & 0 \\
\hline 62 & 0 & 0 & 0 & 0 & 0 & 0 & 0 & 0 & 0 & 0 & 0 & 0 & 0 & 0 & 0 & 0 & 0 & 0 & 0 & 0 & 0 & 1 & 0 & 0 & 0 & 0 \\
\hline 63 & 0 & 0 & 1 & 0 & 0 & 0 & 0 & 0 & 1 & 0 & 0 & 0 & 0 & 0 & 0 & 0 & 0 & 0 & 0 & 0 & 1 & 0 & 0 & 0 & 0 & 0 \\
\hline 64 & 0 & 0 & 0 & 0 & 1 & 0 & 0 & 0 & 1 & 0 & 0 & 0 & 0 & 1 & 0 & 0 & 0 & 0 & 0 & 0 & 0 & 0 & 0 & 0 & 0 & 0 \\
\hline 66 & 0 & 0 & 1 & 0 & 0 & 0 & 0 & 0 & 0 & 0 & 0 & 0 & 0 & 0 & 0 & 0 & 0 & 0 & 0 & 0 & 0 & 0 & 0 & 0 & 0 & 0 \\
\hline
\end{tabular}


Sample Results from the Interrespondent Matrix - Analyses of Participants' Choice of Strategies per Indicator (continued)

Strategies Present in Indicator 3: 56 Responses of 63 Possible Open-Ended Responses (continued)

\begin{tabular}{|c|c|c|c|c|c|c|c|c|c|c|c|c|c|c|c|c|c|c|c|c|c|c|c|c|c|c|}
\hline 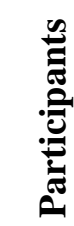 & 常 & م & 苞 & 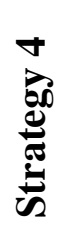 & مَ & 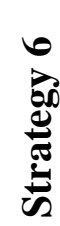 & 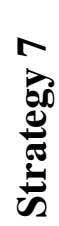 & 赵 & क) & 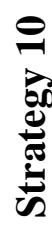 & 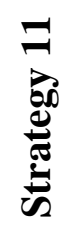 & 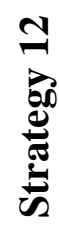 & 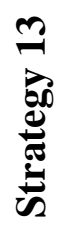 & 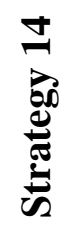 & مَ & 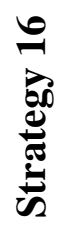 & 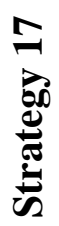 & م & 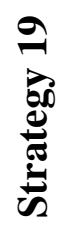 & 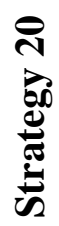 & 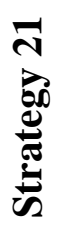 & 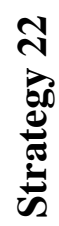 & 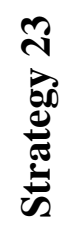 & 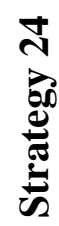 & 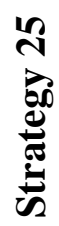 & 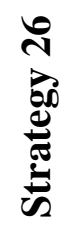 \\
\hline 67 & 0 & 0 & 0 & 0 & 0 & 0 & 0 & 0 & 0 & 0 & 1 & 0 & 0 & 0 & 0 & 0 & 0 & 0 & 0 & 0 & 0 & 0 & 0 & 0 & 0 & 0 \\
\hline 68 & 0 & 0 & 0 & 0 & 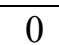 & 0 & 0 & 0 & 1 & & 0 & 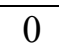 & 0 & 0 & 0 & & & & 0 & & & & & & 0 & 0 \\
\hline 69 & 0 & 0 & 0 & 0 & 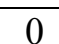 & 0 & 0 & 0 & 1 & & 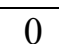 & 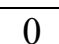 & 0 & 1 & 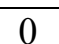 & & & & 0 & & & & & & 0 & 0 \\
\hline 70 & 0 & 0 & 0 & 0 & ( & 0 & 0 & 0 & 1 & 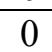 & 0 & 0 & 0 & 1 & 0 & & & & 0 & & & & & U & 0 & 0 \\
\hline$\%$ & 13 & 4 & 23 & 2 & 14 & 20 & 4 & 11 & 46 & 2 & 11 & 4 & 4 & 18 & 0 & & 4 & 2 & 2 & 0 & 9 & 5 & 2 & 2 & 0 & 11 \\
\hline
\end{tabular}


APPENDIX L

\section{RANK OF STRATEGIES USED PER INDICATOR}


Rank of Strategies Used per Indicator

Indicator 1: differentiate between appropriate and inappropriate uses of technology for students' grade level and content area.

\begin{tabular}{|c|c|c|c|c|}
\hline $\begin{array}{c}\text { Very Often Used } \\
>40 \\
\end{array}$ & $\begin{array}{c}\text { Often Used } \\
40-31 \\
\end{array}$ & $\begin{array}{c}\text { Occasionally Used } \\
30-21 \\
\end{array}$ & $\begin{array}{c}\text { Rarely Used } \\
20-11 \\
\end{array}$ & $\begin{array}{c}\text { Very Rarely Used } \\
10-1 \\
\end{array}$ \\
\hline $\begin{array}{ll} & \text { Strategy 1: } \\
& \text { Identifying/Defining } \\
& \text { appropriate use of IT }\end{array}$ & $\begin{array}{ll} & \text { Strategy 3: } \\
\text { Evaluation/Critique/ } \\
\text { Assessment }\end{array}$ & $\begin{array}{ll}\text { - } & \text { Strategy 9: Appropriate } \\
\text { (Lesson/Learning } \\
\text { Activity) Development } \\
\text { - } & \text { Strategy 6: } \\
& \text { Presentation/Demo/ } \\
& \text { Hands on } \\
\text { - } & \text { Strategy 10: } \\
& \text { Referencing Standards }\end{array}$ & None & $\begin{array}{ll}\text { - } & \text { Strategy 12: Grouping } \\
\text { - } & \text { Strategy 26: Lesson Implementation } \\
\text { - } & \text { Strategy 11: Team Work/Group } \\
& \text { Discussion/Peer Discussion } \\
\text { - } & \text { Strategy 8: Mentoring/Consultation } \\
\text { - } & \text { Strategy 22: Specific Assessment } \\
& \text { Tool } \\
\text { - } & \text { Strategy 14: Problem- Based } \\
& \text { Learning/Project-Based Learning } \\
\text { - } & \text { Strategy 4: Observation } \\
\text { - } & \text { Strategy 5: Modeling } \\
\text { - } & \text { Strategy 7: Examples } \\
\text { - } & \text { Strategy 2: } \\
& \text { Exemplars/Models/Experts } \\
\text { - } & \text { Strategy 17: Special Funding/Special } \\
& \text { Incentives } \\
\text { - } & \text { Strategy 20: Made Technology } \\
& \text { Available } \\
\text { - } & \text { Strategy 16: Present/Develop/Use } \\
& \text { Rubrics } \\
\text { - } \quad \text { Strategy 21: Technology Support } \\
\text { - Teams } \\
\text { - Strategy 13: Appropriate Lesson } \\
\text { Development and Assessment } \\
\text { Strategy 23: Faculty Research } \\
\text { (Presentations/Conferences) }\end{array}$ \\
\hline
\end{tabular}


Rank of Strategies Used per Indicator (continued)

Indicator 2: design and implement learning activities that integrate technology to support and expand students' critical thinking.

\begin{tabular}{|c|c|c|c|c|}
\hline $\begin{array}{c}\text { Very Often Used } \\
>40\end{array}$ & $\begin{array}{c}\text { Often Used } \\
40-31 \\
\end{array}$ & $\begin{array}{c}\text { Occasionally Used } \\
30-21 \\
\end{array}$ & $\begin{array}{c}\text { Rarely Used } \\
20-11 \\
\end{array}$ & $\begin{array}{c}\text { Very Rarely Used } \\
10-1\end{array}$ \\
\hline $\begin{array}{ll}\text { - } & \text { Strategy 1: } \\
\text { Identifying/Defining } \\
\text { appropriate use of IT } \\
\text { - Strategy 9: } \\
\text { Appropriate } \\
\text { (Lesson/Learning } \\
\text { Activity) } \\
\text { Development }\end{array}$ & None & $\begin{array}{ll}\text { - } & \text { Strategy 3: } \\
\text { Evaluation/Critique/ } \\
\text { Assessment } \\
\text { - Strategy 6: } \\
\text { Presentation/Demo/ } \\
\text { Hands on }\end{array}$ & $\begin{array}{ll}\text { - } & \text { Strategy 14: Problem- } \\
\text { Based } \\
\text { Learning/Project-Based } \\
\text { Learning } \\
\text { - } \\
\text { Strategy 26: Lesson } \\
\text { Implementation }\end{array}$ & 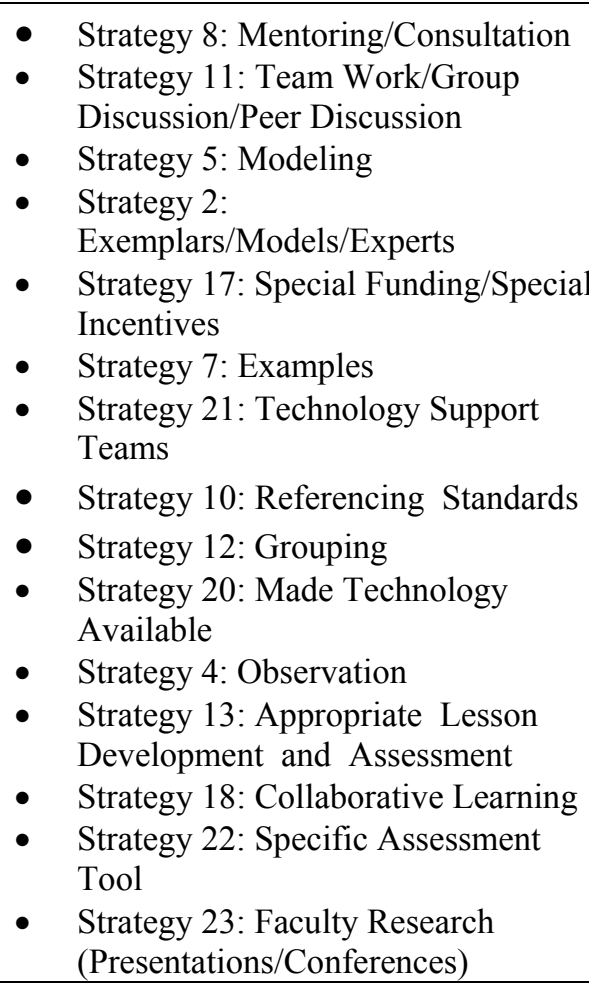 \\
\hline
\end{tabular}


Rank of Strategies Used per Indicator (continued)

Indicator 3: design and implement learning activities that integrate technology to support and expand students' problem solving skills.

\begin{tabular}{|c|c|c|c|c|}
\hline $\begin{array}{c}\text { Very Often Used } \\
>40\end{array}$ & $\begin{array}{c}\text { Often Used } \\
40-31\end{array}$ & $\begin{array}{c}\text { Occasionally Used } \\
30-21\end{array}$ & $\begin{array}{c}\text { Rarely Used } \\
20-11 \\
\end{array}$ & $\begin{array}{c}\text { Very Rarely Used } \\
10-1 \\
\end{array}$ \\
\hline $\begin{array}{l}\text { - } \text { Strategy 9: } \\
\text { Appropriate } \\
\text { (Lesson/Learning } \\
\text { Activity) } \\
\text { Development }\end{array}$ & None & $\begin{array}{ll} & \text { Strategy 3: } \\
\text { Evaluation/Critique/ } \\
\text { Assessment }\end{array}$ & $\begin{array}{ll}\text { - } & \text { Strategy 6: } \\
\text { Presentation/Demo/ } \\
\text { Hands on } \\
\text { - Strategy 14: Problem- } \\
\text { Based } \\
\text { Learning/Project-Based } \\
\text { Learning } \\
\text { - Strategy 5: Modeling } \\
\text { - } & \text { Strategy 1: } \\
\text { Identifying/Defining } \\
\text { appropriate use of IT } \\
\text { - Strategy 8: } \\
\text { Mentoring/Consultation } \\
\text { - Strategy 11: Team } \\
\text { Work/Group } \\
\text { Discussion/Peer } \\
\text { Discussion } \\
\text { Strategy 26: Lesson } \\
\text { Implementation }\end{array}$ & $\begin{array}{ll} & \text { Strategy 21: Technology Support } \\
& \text { Teams } \\
\text { - } & \text { Strategy 22: Specific Assessment } \\
& \text { Tool } \\
\text { - } & \text { Strategy 7: Examples } \\
\text { - } & \text { Strategy 12: Grouping } \\
\text { - } & \text { Strategy 13: Appropriate Lesson } \\
& \text { Development and Assessment } \\
\text { - } & \text { Strategy 17: Special Funding/Special } \\
& \text { Incentives } \\
\text { - } & \text { Strategy 2: } \\
& \text { Exemplars/Models/Experts } \\
\text { - } & \text { Strategy 4: Observation } \\
\text { - } & \text { Strategy 10: Referencing Standards } \\
\text { - } & \text { Strategy 16: Present/Develop/Use } \\
& \text { Rubrics } \\
\text { - Strategy 18: Collaborative Learning } \\
\text { - Strategy 19: Telecollaboration } \\
\text { - Strategy 23: Faculty Research } \\
\text { - } \quad \text { Presentations/Conferences) } \\
\text { Modification }\end{array}$ \\
\hline
\end{tabular}


Rank of Strategies Used per Indicator (continued)

Indicator 4: design and implement learner-centered lessons that are based on the current best practices for integrating the learning of subject matter and student technology standards.

\begin{tabular}{|c|c|c|c|c|}
\hline $\begin{array}{c}\text { Very Often Used } \\
>40\end{array}$ & $\begin{array}{c}\text { Often Used } \\
40-31 \\
\end{array}$ & $\begin{array}{c}\text { Occasionally Used } \\
30-21 \\
\end{array}$ & $\begin{array}{c}\text { Rarely Used } \\
20-11 \\
\end{array}$ & $\begin{array}{c}\text { Very Rarely Used } \\
10-1\end{array}$ \\
\hline $\begin{array}{l}\text { Strategy 9: } \\
\text { Appropriate } \\
\text { (Lesson/Learning } \\
\text { Activity) } \\
\text { Development }\end{array}$ & None & $\begin{array}{l}\text { - } \quad \text { Strategy 10: } \\
\text { Referencing Standards }\end{array}$ & $\begin{array}{l}\text { - Strategy 3: } \\
\text { Evaluation/Critique/ } \\
\text { Assessment } \\
\text { - Strategy 6: } \\
\text { Presentation/Demo/ } \\
\text { Hands on } \\
\text { - Strategy 1: } \\
\text { Identifying/Defining } \\
\text { appropriate use of IT } \\
\text { - Strategy 2: } \\
\text { Exemplars/Models/Exp } \\
\text { erts } \\
\text { - Strategy 5: Modeling } \\
\text { Strategy 26: Lesson } \\
\text { Implementation } \\
\text { Strategy 7: Examples } \\
\end{array}$ & $\begin{array}{ll}\text { - } & \text { Strategy 14: Problem- Based } \\
& \text { Learning/Project-Based Learning } \\
\text { - } & \text { Strategy 8: Mentoring/Consultation } \\
\text { - } & \text { Strategy 11: Team Work/Group } \\
& \text { Discussion/Peer Discussion } \\
\text { - } & \text { Strategy 13: Appropriate Lesson } \\
& \text { Development and Assessment } \\
\text { - } & \text { Strategy 15: Standards Specific } \\
\text { - } & \text { Training } \\
\text { - } & \text { Strategy 18: Collaborative Learning } \\
\text { - } & \text { Strategy 4: Observation } \\
\text { - } & \text { Strategy 21: Technology Support } \\
& \text { Teams } \\
\text { - Strategy 23: Faculty Research } \\
\text { - } \text { (Presentations/Conferences) } \\
\text { Strategy 24: Course/Curriculum } \\
\text { Modification }\end{array}$ \\
\hline
\end{tabular}


Rank of Strategies Used per Indicator (continued)

Indicator 5: assess learner-centered lessons that are based on the current best practices for integrating subject matter and student technology standards.

\begin{tabular}{|c|c|c|c|c|}
\hline $\begin{array}{c}\text { Very Often Used } \\
>40\end{array}$ & $\begin{array}{c}\text { Often Used } \\
40-31\end{array}$ & $\begin{array}{c}\text { Occasionally Used } \\
\text { 30-21 } \\
\end{array}$ & $\begin{array}{c}\text { Rarely Used } \\
20-11 \\
\end{array}$ & $\begin{array}{c}\text { Very Rarely Used } \\
10-1 \\
\end{array}$ \\
\hline None & $\begin{array}{ll}\text { - Strategy 10: } \\
\text { Referencing } \\
\text { Standards } \\
\text { - Strategy 3: } \\
\text { Evaluation/Critique/ } \\
\text { Assessment }\end{array}$ & None & $\begin{array}{ll}\text { - } & \text { Strategy 2: } \\
& \text { Exemplars/Models/ } \\
\text { Experts } \\
\text { - } & \text { Strategy 13: } \\
& \text { Appropriate Lesson } \\
\text { Development and } \\
\text { Assessment } \\
\text { - Strategy 16: } \\
\text { Present/Develop/Use } \\
\text { Rubrics } \\
\text { - Strategy 9: Appropriate } \\
\text { (Lesson/Learning } \\
\text { Activity) Development } \\
\text { - Strategy 22: Specific } \\
\text { Assessment Tool } \\
\text { - Strategy 26: Lesson } \\
\text { Implementation }\end{array}$ & $\begin{array}{ll}\text { - } & \text { Strategy 6: Presentation/Demo/ } \\
& \text { Hands on } \\
\text { - } & \text { Strategy 1: Identifying/Defining } \\
& \text { appropriate use of IT } \\
\text { - } & \text { Strategy 7: Examples } \\
\text { - } & \text { Strategy 8: Mentoring/Consultation } \\
\text { - } & \text { Strategy 15: Standards Specific } \\
& \text { Training } \\
\text { - } & \text { Strategy 4: Observation } \\
\text { - } & \text { Strategy 5: Modeling } \\
\text { - } & \text { Strategy 11: Team Work/Group } \\
& \text { Discussion/Peer Discussion } \\
\text { - } & \text { Strategy 14: Problem- Based } \\
& \text { Learning/Project-Based Learning } \\
\text { - } \quad \text { Strategy 18: Collaborative Learning } \\
\text { - Strategy 21: Technology Support } \\
\text { - Teams } \\
\text { - Strategy 25: Resources Development }\end{array}$ \\
\hline
\end{tabular}


Rank of Strategies Used per Indicator (continued)

Indicator 6: design and implement student-centered, instructional materials that take advantage of computers to engage students in their own learning.

\begin{tabular}{|c|c|c|c|c|}
\hline $\begin{array}{c}\text { Very Often Used } \\
>40\end{array}$ & $\begin{array}{c}\text { Often Used } \\
40-31\end{array}$ & $\begin{array}{c}\text { Occasionally Used } \\
30-21\end{array}$ & $\begin{array}{c}\text { Rarely Used } \\
20-11\end{array}$ & $\begin{array}{c}\text { Very Rarely Used } \\
10-1\end{array}$ \\
\hline $\begin{array}{l}\text { - Strategy 9: } \\
\text { Appropriate } \\
\text { (Lesson/Learning } \\
\text { Activity) } \\
\text { Development }\end{array}$ & None & None & $\begin{array}{ll}\text { - } & \text { Strategy 6: } \\
\text { Presentation/Demo/ } \\
\text { Hands on } \\
\text { - Strategy 14: Problem- } \\
\text { Based } \\
\text { Learning/Project-Based } \\
\text { Learning } \\
\text { - Strategy 3: } \\
\text { Evaluation/Critique/ } \\
\text { Assessment } \\
\text { - } & \text { Strategy 5: Modeling } \\
\text { - } & \text { Strategy 1: } \\
\text { Identifying/Defining } \\
\text { appropriate use of IT }\end{array}$ & $\begin{array}{ll}\text { - } & \text { Strategy 11: Team Work/Group } \\
& \text { Discussion/Peer Discussion } \\
\text { - } & \text { Strategy 25: Resources Development } \\
\text { - } & \text { Strategy 26: Lesson Implementation } \\
\text { - } & \text { Strategy 2: Exemplars/Models/ } \\
& \text { Experts } \\
\text { - } & \text { Strategy 7: Examples } \\
\text { - } & \text { Strategy 8: Mentoring/Consultation } \\
\text { - } & \text { Strategy 10: Referencing Standards } \\
\text { - } & \text { Strategy 21: Technology Support } \\
& \text { Teams } \\
\text { - } & \text { Strategy 4: Observation } \\
\text { - } & \text { Strategy 16: Present/Develop/Use } \\
& \text { Rubrics } \\
\text { - } & \text { Strategy 17: Special Funding/Special } \\
& \text { Incentives } \\
\text { - Strategy 18: Collaborative Learning } \\
\text { - Strategy 24: Course/Curriculum } \\
\text { - Modification } \\
\text { - Strategy 20: Made Technology } \\
\text { Available } \\
\text { Strategy 23: Faculty Research } \\
\text { (Presentations/Conferences) }\end{array}$ \\
\hline
\end{tabular}


Rank of Strategies Used per Indicator (continued)

Indicator 7: design and teach technology-enriched learning activities that connect content, state and national standards with student technology standards.

\begin{tabular}{|c|c|c|c|c|}
\hline $\begin{array}{c}\text { Very Often Used } \\
>40\end{array}$ & $\begin{array}{c}\text { Often Used } \\
40-31\end{array}$ & $\begin{array}{c}\text { Occasionally Used } \\
30-21 \\
\end{array}$ & $\begin{array}{c}\text { Rarely Used } \\
20-11 \\
\end{array}$ & $\begin{array}{c}\text { Very Rarely Used } \\
10-1 \\
\end{array}$ \\
\hline $\begin{array}{l}\text { Strategy 10: } \\
\text { Referencing } \\
\text { Standards }\end{array}$ & $\begin{array}{l}\text { - Strategy 9: } \\
\text { Appropriate } \\
\text { (Lesson/Learning } \\
\text { Activity) } \\
\text { Development }\end{array}$ & $\begin{array}{l}\text { - Strategy 3: } \\
\text { Evaluation/Critique/ } \\
\text { Assessment }\end{array}$ & $\begin{array}{ll}\text { - Strategy 13: } \\
\text { Appropriate Lesson } \\
\text { Development and } \\
\text { Assessment } \\
\text { - Strategy 26: Lesson } \\
\text { Implementation } \\
\text { - Strategy 6: } \\
\text { Presentation/Demo/ } \\
\text { Hands on }\end{array}$ & 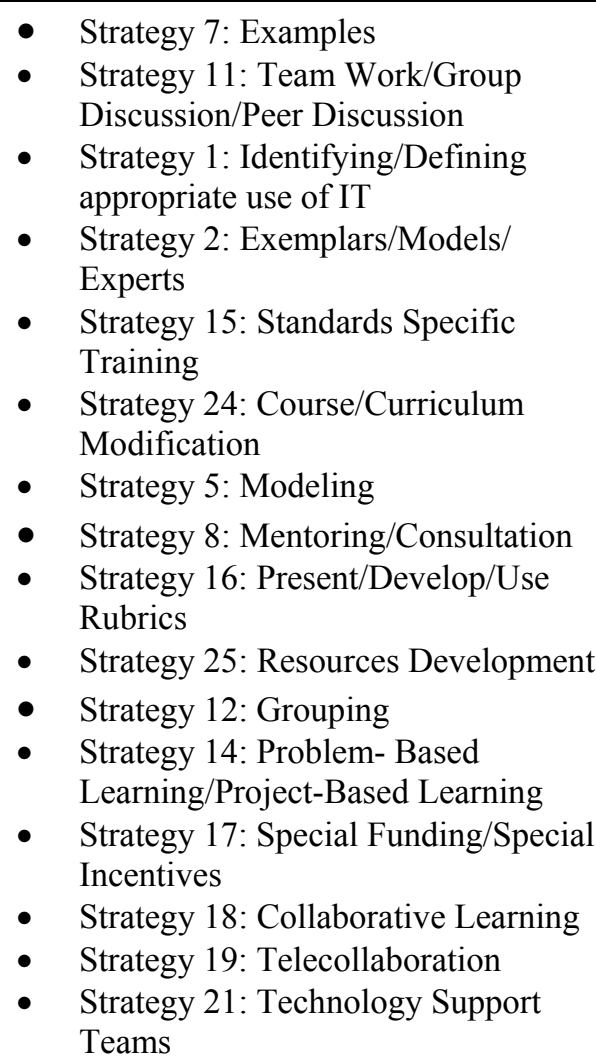 \\
\hline
\end{tabular}


Rank of Strategies Used per Indicator (continued)

Indicator 8: design and teach technology-enriched learning activities that meet the individual needs of students.

\begin{tabular}{|c|c|c|c|c|}
\hline $\begin{array}{c}\text { Very Often Used } \\
>40 \\
\end{array}$ & $\begin{array}{c}\begin{array}{c}\text { Often Used } \\
40-31\end{array} \\
\end{array}$ & $\begin{array}{c}\text { Occasionally Used } \\
30-21 \\
\end{array}$ & $\begin{array}{c}\text { Rarely Used } \\
20-11 \\
\end{array}$ & $\begin{array}{c}\text { Very Rarely Used } \\
10-1 \\
\end{array}$ \\
\hline $\begin{array}{l}\text { - Strategy 9: } \\
\text { Appropriate } \\
\text { (Lesson/Learning } \\
\text { Activity) } \\
\text { Development }\end{array}$ & None & $\begin{array}{l}\text { Strategy 3: } \\
\text { Evaluation/Critique/ } \\
\text { Assessment }\end{array}$ & $\begin{array}{ll} & \text { Strategy 6: } \\
& \text { Presentation/Demo/ } \\
& \text { Hands on } \\
\text { - } & \text { Strategy 1: } \\
& \text { Identifying/Defining } \\
& \text { appropriate use of IT } \\
\text { - } & \text { Strategy 7: Examples } \\
\text { - } & \text { Strategy 10: } \\
& \text { Referencing Standards } \\
\text { - } & \text { Strategy 26: Lesson } \\
& \text { Implementation }\end{array}$ & $\begin{array}{ll}\text { - } & \text { Strategy 2: Exemplars/Models/ } \\
& \text { Experts } \\
\text { - } & \text { Strategy 8: Mentoring/Consultation } \\
\text { - } & \text { Strategy 16: Present/Develop/Use } \\
& \text { Rubrics } \\
\text { - } & \text { Strategy 5: Modeling } \\
\text { - } & \text { Strategy 14: Problem- Based } \\
& \text { Learning/Project-Based Learning } \\
\text { - } & \text { Strategy 20: Made Technology } \\
& \text { Available } \\
\text { - } & \text { Strategy 22: Specific Assessment } \\
& \text { Tool } \\
\text { - } & \text { Strategy 11: Team Work/Group } \\
& \text { Discussion/Peer Discussion } \\
\text { - } & \text { Strategy 12: Grouping } \\
\text { - Strategy 17: Special Funding/Special } \\
\text { - } \text { Incentives } \\
\text { - Strategy 18: Collaborative Learning } \\
\text { - Strategy 19: Telecollaboration } \\
\text { - Ttrategy 21: Technology Support } \\
\text { Teams } \\
\text { Strategy 24: Course/Curriculum } \\
\text { Modification }\end{array}$ \\
\hline
\end{tabular}


Rank of Strategies Used per Indicator (continued)

Indicator 9: design an evaluation plan that applies multiple measures for evaluating technology-based students' products.

\begin{tabular}{|c|c|c|c|c|}
\hline $\begin{array}{c}\text { Very Often Used } \\
>40\end{array}$ & $\begin{array}{l}\text { Often Used } \\
40-31 \\
\end{array}$ & $\begin{array}{c}\text { Occasionally Used } \\
30-21\end{array}$ & $\begin{array}{c}\text { Rarely Used } \\
20-11 \\
\end{array}$ & $\begin{array}{c}\text { Very Rarely Used } \\
10-1\end{array}$ \\
\hline $\begin{array}{l}\text { - Strategy 16: } \\
\text { Present/Develop/Use } \\
\text { Rubrics }\end{array}$ & $\begin{array}{l}\text { - Strategy 3: } \\
\text { Evaluation/Critique/ } \\
\text { Assessment }\end{array}$ & $\begin{array}{l}\text { - Strategy 13: } \\
\text { Appropriate Lesson } \\
\text { Development and } \\
\text { Assessment }\end{array}$ & $\begin{array}{l}\text { Strategy 6: } \\
\text { Presentation/Demo/ } \\
\text { Hands on } \\
\text { - Strategy 22: Specific } \\
\text { Assessment Tool }\end{array}$ & $\begin{array}{ll}\text { - } & \text { Strategy 1: Identifying/Defining } \\
& \text { appropriate use of IT } \\
\text { - } & \text { Strategy 2: Exemplars/Models/ } \\
& \text { Experts } \\
\text { - } & \text { Strategy 5: Modeling } \\
\text { - } & \text { Strategy 7: Examples } \\
\text { - } & \text { Strategy 10: Referencing Standards } \\
\text { - } & \text { Strategy 15: Standards Specific } \\
& \text { Training } \\
\text { - } & \text { Strategy 26: Lesson Implementation }\end{array}$ \\
\hline
\end{tabular}

Indicator 10: participate in online professional collaborations with peers and experts.

\begin{tabular}{|c|c|c|c|c|}
\hline $\begin{array}{c}\text { Very Often Used } \\
>40\end{array}$ & $\begin{array}{c}\text { Often Used } \\
40-31 \\
\end{array}$ & $\begin{array}{c}\text { Occasionally Used } \\
30-21 \\
\end{array}$ & $\begin{array}{c}\text { Rarely Used } \\
20-11 \\
\end{array}$ & $\begin{array}{c}\text { Very Rarely Used } \\
10-1\end{array}$ \\
\hline $\begin{array}{ll} & \text { Strategy 19: } \\
& \text { Telecollaboration }\end{array}$ & None & None & $\begin{array}{ll}\text { - Strategy 6: } \\
\text { Presentation/Demo/ } \\
\text { Hands on }\end{array}$ & $\begin{array}{ll}\text { - } & \text { Strategy 9: Appropriate } \\
\text { (Lesson/Learning Activity) } \\
\text { Development } \\
\text { - Strategy 17: Special Funding/Special } \\
\text { Incentives } \\
\text { - } \quad \text { Strategy 20: Made Technology } \\
\text { Available } \\
\text { - Strategy 18: Collaborative Learning } \\
\text { - Strategy 1: Identifying/Defining } \\
\text { appropriate use of IT } \\
\text { - Strategy 5: Modeling } \\
\text { - Strategy 8: Mentoring/Consultation } \\
\text { - Strategy 21: Technology Support } \\
\text { - Teams } \\
\text { - Strategy 25: Resources Development }\end{array}$ \\
\hline
\end{tabular}


Rank of Strategies Used per Indicator (continued)

Indicator 11: design and facilitate learning experiences that use assistive technologies to meet the special physical needs of students.

\begin{tabular}{|c|c|c|c|c|}
\hline $\begin{array}{c}\text { Very Often Used } \\
>40\end{array}$ & $\begin{array}{c}\text { Often Used } \\
40-31\end{array}$ & $\begin{array}{c}\text { Occasionally Used } \\
30-21\end{array}$ & $\begin{array}{c}\text { Rarely Used } \\
20-11\end{array}$ & $\begin{array}{c}\text { Very Rarely Used } \\
10-1\end{array}$ \\
\hline None & None & None & $\begin{array}{ll}\text { - } & \text { Strategy 6: } \\
\text { Presentation/Demo/ } \\
\text { Hands on } \\
\text { - Strategy 1: } \\
\text { Identifying/Defining } \\
\text { appropriate use of IT } \\
\text { - } & \text { Strategy 9: Appropriate } \\
\text { (Lesson/Learning } \\
\text { Activity) } \\
\text { - Strategy 8: } \\
\text { Mentoring/Consultation } \\
\text { - Strategy 20: Made } \\
\text { Technology Available } \\
\text { - Strategy 7: Examples }\end{array}$ & $\begin{array}{ll} & \text { Strategy 2: Exemplars/Models/ } \\
& \text { Experts } \\
\text { - } & \text { Strategy 12: Grouping } \\
\text { - } & \text { Strategy 17: Special Funding/Special } \\
& \text { Incentives } \\
\text { - } & \text { Strategy 18: Collaborative Learning } \\
\text { - } & \text { Strategy 19: Telecollaboration } \\
\text { - } & \text { Strategy 3: Evaluation/Critique/ } \\
& \text { Assessment } \\
\text { - } & \text { Strategy 5: Modeling }\end{array}$ \\
\hline
\end{tabular}

Indicator 12: guide collaborative learning activities in which students use technology resources to solve authentic problems in the subject area (s).

\begin{tabular}{|c|c|c|c|c|}
\hline $\begin{array}{c}\text { Very Often Used } \\
>40\end{array}$ & $\begin{array}{c}\text { Often Used } \\
40-31\end{array}$ & $\begin{array}{c}\text { Occasionally Used } \\
30-21 \\
\end{array}$ & $\begin{array}{c}\text { Rarely Used } \\
20-11\end{array}$ & $\begin{array}{c}\text { Very Rarely Used } \\
10-1\end{array}$ \\
\hline None & $\begin{array}{ll}\text { Strategy 14: } \\
\text { Problem- Based } \\
\text { Learning/Project- } \\
\text { Based Learning }\end{array}$ & $\begin{array}{l}\text { - Strategy 9: Appropriate } \\
\text { (Lesson/Learning } \\
\text { Activity) }\end{array}$ & $\begin{array}{ll}\text { - } & \text { Strategy 5: Modeling } \\
\text { - } & \text { Strategy 2: } \\
& \text { Exemplars/Models/ } \\
& \text { Experts } \\
\text { - } & \text { Strategy 6: } \\
& \text { Presentation/Demo/ } \\
& \text { Hands on } \\
\text { - } & \text { Strategy 1: } \\
& \text { Identifying/Defining } \\
\text { appropriate use of IT } \\
\text { - Strategy 3: } \\
\text { Evaluation/Critique/ } \\
\text { Assessment } \\
\text { - Strategy 7: Examples }\end{array}$ & $\begin{array}{ll}\text { - } & \text { Strategy 8: Mentoring/Consultation } \\
\text { - } & \text { Strategy 26: Lesson Implementation } \\
\text { - } & \text { Strategy 18: Collaborative Learning } \\
\text { - } & \text { Strategy 11: Team Work/Group } \\
& \text { Discussion/Peer Discussion } \\
\text { - } & \text { Strategy 19: Telecollaboration } \\
\text { - } & \text { Strategy 24: Course/Curriculum } \\
& \text { Modification } \\
\text { - } & \text { Strategy 25: Resources Development } \\
\text { - } & \text { Strategy 10: Referencing Standards } \\
\text { - } & \text { Strategy 12: Grouping } \\
\text { - } & \text { Strategy 17: Special Funding/Special } \\
& \text { Incentives }\end{array}$ \\
\hline
\end{tabular}


Rank of Strategies Used per Indicator (continued)

Indicator 13: arrange equitable access to appropriate technology resources that enable students to engage successfully in learning activities across subject/content areas and grade levels.

\begin{tabular}{|c|c|c|c|c|}
\hline $\begin{array}{c}\text { Very Often Used } \\
>40\end{array}$ & $\begin{array}{c}\text { Often Used } \\
40-31 \\
\end{array}$ & $\begin{array}{c}\text { Occasionally Used } \\
30-21\end{array}$ & $\begin{array}{c}\text { Rarely Used } \\
20-11 \\
\end{array}$ & $\begin{array}{c}\text { Very Rarely Used } \\
10-1\end{array}$ \\
\hline $\begin{array}{l}\text { - Strategy 20: Made } \\
\text { Technology } \\
\text { Available }\end{array}$ & None & $\begin{array}{l}\text { - } \\
\text { Strategy 1: } \\
\text { Identifying/Defining } \\
\text { appropriate use of IT }\end{array}$ & $\begin{array}{ll}\text { - } & \text { Strategy 6: } \\
\text { Presentation/Demo/ } \\
\text { Hands on } \\
\text { - Strategy 3: } \\
\text { Evaluation/Critique/ } \\
\text { Assessment } \\
\text { - Strategy 11: Team } \\
\text { Work/Group } \\
\text { Discussion/Peer } \\
\text { Discussion }\end{array}$ & $\begin{array}{ll}\text { - } & \text { Strategy 2: Exemplars/Models/ } \\
\text { - } & \text { Experts } \\
\text { - } & \text { Strategy 7: Examples } \\
\text { - } & \text { Strategy 8: Mentoring/Consultation 14: Problem- Based } \\
& \text { Learning/Project-Based Learning } \\
\text { - } & \text { Strategy 5: Modeling } \\
\text { - } & \text { Strategy 10: Referencing Standards } \\
\text { - } & \text { Strategy 17: Special Funding/Specia } \\
\text { - } & \text { Incentives } \\
\text { - } & \text { Strategy 18: Collaborative Learning } \\
\text { - } & \text { Strategy 26: Lesson Implementation }\end{array}$ \\
\hline
\end{tabular}


Indicator 14: plan and implement technology-based learning activities that promote student engagement in analysis, synthesis, interpretation, and creation of original products.

\begin{tabular}{|c|c|c|c|c|}
\hline $\begin{array}{c}\text { Very Often Used } \\
>40\end{array}$ & $\begin{array}{c}\text { Often Used } \\
40-31\end{array}$ & $\begin{array}{c}\text { Occasionally Used } \\
30-21\end{array}$ & $\begin{array}{c}\text { Rarely Used } \\
20-11\end{array}$ & $\begin{array}{c}\text { Very Rarely Used } \\
10-1\end{array}$ \\
\hline $\begin{array}{l}\text { Strategy 9: } \\
\text { Appropriate } \\
\text { (Lesson/Learning } \\
\text { Activity) }\end{array}$ & None & $\begin{array}{ll}\text { - } & \text { Strategy 1: } \\
\text { Identifying/Defining } \\
\text { appropriate use of IT } \\
\text { Strategy 14: Problem- } \\
\text { Based } \\
\text { Learning/Project-Based } \\
\text { Learning }\end{array}$ & $\begin{array}{ll}\text { - } & \text { Strategy 2: } \\
& \text { Exemplars/Models/ } \\
& \text { Experts } \\
\text { - } & \text { Strategy 6: } \\
& \text { Presentation/Demo/ } \\
& \text { Hands on } \\
\text { - } & \text { Strategy 26: Lesson } \\
& \text { Implementation } \\
\text { - } & \text { Strategy 3: } \\
& \text { Evaluation/Critique/ } \\
\text { Assessment } \\
\text { - Strategy 7: Examples }\end{array}$ & $\begin{array}{ll}\text { - } & \text { Strategy 5: Modeling } \\
\text { - } & \text { Strategy 8: Mentoring/Consultation } \\
\text { - } & \text { Strategy 10: Referencing Standards } \\
\text { - } & \text { Strategy 11: Team Work/Group } \\
& \text { Discussion/Peer Discussion } \\
\text { - } & \text { Strategy 16: Present/Develop/Use } \\
& \text { Rubrics } \\
\text { - } & \text { Strategy 17: Special Funding/Special } \\
& \text { Incentives } \\
\text { - } & \text { Strategy 18: Collaborative Learning } \\
\text { - } & \text { Strategy 19: Telecollaboration } \\
\text { - } & \text { Strategy 21: Technology Support } \\
& \text { Teams } \\
\text { - } & \text { Strategy 4: Observation } \\
\text { - Strategy 13: Appropriate Lesson } \\
\text { - } \quad \text { Strategy 20: Made Technology } \\
\text { Available }\end{array}$ \\
\hline
\end{tabular}


Rank of Strategies Used per Indicator (continued)

Indicator 15: facilitate students' use of technology that addresses their social needs and cultural identity.

\begin{tabular}{|c|c|c|c|c|}
\hline $\begin{array}{c}\text { Very Often Used } \\
>40 \\
\end{array}$ & $\begin{array}{c}\text { Often Used } \\
40-31 \\
\end{array}$ & $\begin{array}{c}\text { Occasionally Used } \\
30-21 \\
\end{array}$ & $\begin{array}{c}\text { Rarely Used } \\
20-11 \\
\end{array}$ & $\begin{array}{c}\text { Very Rarely Used } \\
10-1 \\
\end{array}$ \\
\hline & $\begin{array}{ll} & \text { Strategy 6: } \\
\text { Presentation/Demo/ } \\
\text { Hands on }\end{array}$ & $\begin{array}{ll}\text { - } & \text { Strategy 1: } \\
\text { Identifying/Defining } \\
\text { appropriate use of IT } \\
\text { - } \\
\text { Strategy 8: } \\
\text { Mentoring/Consultation } \\
\text { - } & \text { Strategy 9: Appropriate } \\
\text { (Lesson/Learning } \\
\text { Activity) }\end{array}$ & $\begin{array}{ll}\text { - Strategy 26: Lesson } \\
\text { Implementation } \\
\text { - Strategy 11: Team } \\
\text { Work/Group } \\
\text { Discussion/Peer } \\
\text { Discussion }\end{array}$ & $\begin{array}{ll} & \text { Strategy 2: Exemplars/Models/ } \\
& \text { Experts } \\
\text { - } & \text { Strategy 3: Evaluation/Critique/ } \\
& \text { Assessment } \\
\text { - } & \text { Strategy 5: Modeling } \\
\text { - } & \text { Strategy 7: Examples } \\
\text { - } & \text { Strategy 14: Problem- Based } \\
& \text { Learning/Project-Based Learning } \\
\text { - } & \text { Strategy 17: Special Funding/Special } \\
& \text { Incentives } \\
\text { - } & \text { Strategy 18: Collaborative Learning } \\
\text { - } & \text { Strategy 19: Telecollaboration } \\
\text { - } & \text { Strategy 21: Technology Support } \\
& \text { Teams } \\
\text { - } & \text { Strategy 25: Resources Development }\end{array}$ \\
\hline
\end{tabular}

\begin{tabular}{|c|c|c|c|c|}
\hline \multicolumn{5}{|c|}{ Indicator 16: facilitate students' use of technology that promotes their interaction with the global community. } \\
\hline $\begin{array}{c}\text { Very Often Used } \\
>40\end{array}$ & $\begin{array}{c}\text { Often Used } \\
40-31\end{array}$ & $\begin{array}{c}\text { Occasionally Used } \\
30-21\end{array}$ & $\begin{array}{c}\text { Rarely Used } \\
20-11\end{array}$ & $\begin{array}{c}\text { Very Rarely Used } \\
10-1\end{array}$ \\
\hline $\begin{array}{ll}\text { - } & \text { Strategy 19: } \\
& \text { Telecollaboration }\end{array}$ & None & $\begin{array}{l}\text { Strategy 1: } \\
\text { Identifying/Defining } \\
\text { appropriate use of IT }\end{array}$ & $\begin{array}{ll}\text { - Strategy 6: } \\
\text { Presentation/Demo/ } \\
\text { Hands on } \\
\text { - Strategy 2: } \\
\text { Exemplars/Models/ } \\
\text { Experts } \\
\text { - Strategy 3: } \\
\text { Evaluation/Critique/ } \\
\text { Assessment }\end{array}$ & $\begin{array}{ll}\text { - } & \text { Strategy 8: Mentoring/Consultation } \\
\text { - } & \text { Strategy 14: Problem- Based } \\
& \text { Learning/Project-Based Learning } \\
\text { - } & \text { Strategy 18: Collaborative Learning } \\
\text { - } & \text { Strategy 9: Appropriate } \\
& \text { (Lesson/Learning Activity) } \\
\text { - } & \text { Strategy 21: Technology Support } \\
& \text { Teams } \\
\text { - } & \text { Strategy 23: Faculty Research } \\
& \text { (Presentations/Conferences) } \\
\text { - } & \text { Strategy 26: Lesson Implementation }\end{array}$ \\
\hline
\end{tabular}


Rank of Strategies Used per Indicator (continued)

Indicator 17: structure a learning environment where student collaboration is the common practice when using technology.

\begin{tabular}{|c|c|c|c|c|}
\hline $\begin{array}{c}\text { Very Often Used } \\
>40\end{array}$ & $\begin{array}{c}\text { Often Used } \\
40-31 \\
\end{array}$ & $\begin{array}{c}\text { Occasionally Used } \\
30-21 \\
\end{array}$ & $\begin{array}{c}\text { Rarely Used } \\
20-11 \\
\end{array}$ & $\begin{array}{c}\text { Very Rarely Used } \\
10-1\end{array}$ \\
\hline None & None & $\begin{array}{l}\text { Strategy 1: } \\
\text { Identifying/Defining } \\
\text { appropriate use of IT }\end{array}$ & $\begin{array}{ll}\text { - } & \text { Strategy 5: Modeling } \\
\text { - } & \text { Strategy 6: } \\
& \text { Presentation/Demo/ } \\
& \text { Hands on } \\
\text { - } & \text { Strategy 11: Team } \\
& \text { Work/Group } \\
& \text { Discussion/Peer } \\
& \text { Discussion } \\
\text { - } & \text { Strategy 14: Problem- } \\
& \text { Based } \\
& \text { Learning/Project-Based } \\
& \text { Learning } \\
\text { - } & \text { Strategy 9: Appropriate } \\
& \text { (Lesson/Learning } \\
& \text { Activity) } \\
\text { - } & \text { Strategy 18: } \\
& \text { Collaborative Learning } \\
\text { - } & \text { Strategy 8: } \\
& \text { Mentoring/Consultation } \\
\text { - } & \text { Strategy 19: } \\
& \text { Telecollaboration }\end{array}$ & $\begin{array}{ll}\text { - } & \text { Strategy 2: Exemplars/Models/ } \\
& \text { Experts } \\
\text { - } & \text { Strategy 3: Evaluation/Critique/ } \\
& \text { Assessment } \\
\text { - } & \text { Strategy 20: Made Technology } \\
& \text { Available } \\
\text { - } & \text { Strategy 7: Examples } \\
\text { - } & \text { Strategy 17: Special Funding/Special } \\
& \text { Incentives } \\
\text { - } & \text { Strategy 26: Lesson Implementation } \\
\text { - } & \text { Strategy 10: Referencing Standards } \\
\text { - Strategy 19: Telecollaboration } \\
\text { - Strategy 21: Technology Support } \\
\end{array}$ \\
\hline
\end{tabular}


Rank of Strategies Used per Indicator (continued)

Indicator 18: use students' interests, experiences when planning a variety of computer-related activities.

\begin{tabular}{|c|c|c|c|c|}
\hline $\begin{array}{c}\text { Very Often Used } \\
>40\end{array}$ & $\begin{array}{c}\text { Often Used } \\
40-31\end{array}$ & $\begin{array}{c}\text { Occasionally Used } \\
30-21\end{array}$ & $\begin{array}{c}\text { Rarely Used } \\
20-11\end{array}$ & $\begin{array}{c}\text { Very Rarely Used } \\
10-1\end{array}$ \\
\hline None & $\begin{array}{l}\text { - Strategy 9: } \\
\text { Appropriate } \\
\text { (Lesson/Learning } \\
\text { Activity) }\end{array}$ & None & $\begin{array}{ll}\text { - Strategy 3: } \\
\text { Evaluation/Critique/ } \\
\text { Assessment } \\
\text { - Strategy 5: Modeling } \\
\text { - } \quad \text { Strategy 6: } \\
\text { Presentation/Demo/ } \\
\text { Hands on } \\
\text { - Strategy 8: } \\
\text { Mentoring/Consultation } \\
\text { - Strategy 1: } \\
\text { Identifying/Defining } \\
\text { appropriate use of IT } \\
\text { Strategy 14: Problem- } \\
\text { Based } \\
\text { Learning/Project-Based } \\
\text { Learning } \\
\text { - Strategy 26: Lesson } \\
\text { Implementation }\end{array}$ & $\begin{array}{ll}\text { - } & \text { Strategy 2: Exemplars/Models/ } \\
& \text { Experts } \\
\text { - } & \text { Strategy 11: Team Work/Group } \\
& \text { Discussion/Peer Discussion } \\
\text { - } & \text { Strategy 7: Examples } \\
\text { - } & \text { Strategy 10: Referencing Standards } \\
\text { - } & \text { Strategy 17: Special Funding/Special } \\
& \text { Incentives } \\
\text { - } & \text { Strategy 18: Collaborative Learning } \\
\text { - } & \text { Strategy 24: Course/Curriculum } \\
& \text { Modification }\end{array}$ \\
\hline
\end{tabular}

Indicator 19: implement project-based learning that emphasizes critical content and higher-order thinking skills (e.g., analysis, synthesis, evaluation) using the available computers.

\begin{tabular}{|c|c|c|c|c|}
\hline $\begin{array}{l}\text { Very Often Used } \\
>40\end{array}$ & $\begin{array}{c}\text { Often Used } \\
40-31\end{array}$ & $\begin{array}{c}\text { Occasionally Used } \\
\text { 30-21 }\end{array}$ & $\begin{array}{c}\text { Rarely Used } \\
20-11\end{array}$ & $\begin{array}{c}\text { Very Rarely Used } \\
10-1\end{array}$ \\
\hline None & $\begin{array}{l}\text { - Strategy 6: } \\
\text { Presentation/Demo/ } \\
\text { Hands on }\end{array}$ & $\begin{array}{ll}\text { - } & \text { Strategy 5: Modeling } \\
\text { - } & \text { Strategy 9: Appropriate } \\
\text { (Lesson/Learning } \\
\text { Activity) } \\
\text { - Strategy 14: Problem- } \\
\text { Based } \\
\text { Learning/Project-Based } \\
\text { Learning } \\
\text { Strategy 3: } \\
\text { Evaluation/Critique } \\
\end{array}$ & $\begin{array}{ll}\text { - } & \text { Strategy 7: Examples } \\
\text { - } & \text { Strategy 1: } \\
& \text { Identifying/Defining } \\
& \text { appropriate use of IT } \\
\text { - } & \text { Strategy 2: } \\
& \text { Exemplars/Models/ } \\
\text { Experts }\end{array}$ & $\begin{array}{ll}\text { - } & \text { Strategy 10: Referencing Standards } \\
\text { - } & \text { Strategy 26: Lesson Implementation } \\
\text { - } & \text { Strategy 11: Team Work/Group } \\
& \text { Discussion/Peer Discussion } \\
\text { - } & \text { Strategy 16: Present/Develop/Use } \\
& \text { Rubrics } \\
\text { - } & \text { Strategy 18: Collaborative Learning } \\
\text { - } & \text { Strategy 8: Mentoring/Consultation }\end{array}$ \\
\hline
\end{tabular}




\section{Rank of Strategies Used per Indicator (continued)}

Indicator 20: design and implement web-based projects that emphasize complex thinking skill strategies such as problem-solving, scientific inquiry, or decision-making.

\begin{tabular}{|c|c|c|c|c|}
\hline $\begin{array}{c}\text { Very Often Used } \\
>40\end{array}$ & $\begin{array}{c}\text { Often Used } \\
40-31 \\
\end{array}$ & $\begin{array}{c}\text { Occasionally Used } \\
30-21 \\
\end{array}$ & $\begin{array}{c}\text { Rarely Used } \\
20-11 \\
\end{array}$ & $\begin{array}{c}\text { Very Rarely Used } \\
10-1 \\
\end{array}$ \\
\hline $\begin{array}{ll}\text { - } & \text { Strategy 9: } \\
\text { Appropriate } \\
\text { (Lesson/Learning } \\
\text { Activity) } \\
\text { Strategy 14: } \\
\text { Problem- Based } \\
\text { Learning/Project- } \\
\text { Based Learning }\end{array}$ & None & None & $\begin{array}{ll}\text { - } & \text { Strategy 6: } \\
& \text { Presentation/Demo/ } \\
& \text { Hands on } \\
\text { - } & \text { Strategy 7: Examples } \\
\text { - } & \text { Strategy 26: Lesson } \\
& \text { Implementation }\end{array}$ & $\begin{array}{ll}\text { - } & \text { Strategy 1: Identifying/Defining } \\
& \text { appropriate use of IT } \\
\text { - } & \text { Strategy 19: Telecollaboration } \\
\text { - } & \text { Strategy 2: Exemplars/Models/ } \\
& \text { Experts } \\
\text { - } & \text { Strategy 3: Evaluation/Critique/ } \\
& \text { Assessment } \\
\text { - } & \text { Strategy 11: Team Work/Group } \\
& \text { Discussion/Peer Discussion } \\
\text { - } & \text { Strategy 21: Technology Support } \\
& \text { Teams } \\
\text { - } & \text { Strategy 24: Course/Curriculum } \\
& \text { Modification } \\
\text { - } & \text { Strategy 10: Referencing Standard } \\
\text { - } & \text { Strategy 5: Modeling } \\
\text { - } & \text { Strategy 8: Mentoring/Consultation }\end{array}$ \\
\hline
\end{tabular}


Rank of Strategies Used per Indicator (continued)

Indicator 21: guide students' use of the Internet for collaboration with others.

\begin{tabular}{|c|c|c|c|c|}
\hline $\begin{array}{c}\text { Very Often Used } \\
>40\end{array}$ & $\begin{array}{l}\text { Often Used } \\
40-31\end{array}$ & $\begin{array}{c}\text { Occasionally Used } \\
30-21\end{array}$ & $\begin{array}{c}\text { Rarely Used } \\
20-11\end{array}$ & $\begin{array}{c}\text { Very Rarely Used } \\
10-1\end{array}$ \\
\hline $\begin{array}{ll}\text { - } & \text { Strategy 19: } \\
& \text { Telecollaboration }\end{array}$ & None & $\begin{array}{l}\text { - Strategy 1: } \\
\text { Identifying/Defining } \\
\text { appropriate use of IT }\end{array}$ & $\begin{array}{ll}\text { - } & \text { Strategy 18: } \\
& \text { Collaborative Learning } \\
\text { - } & \text { Strategy 3: } \\
\text { Evaluation/Critique/ } \\
\text { Assessment } \\
\text { - Strategy 6: } \\
\text { Presentation/Demo/ } \\
\text { Hands on } \\
\text { - Strategy 11: Team } \\
\text { Work/Group } \\
\text { Discussion/Peer } \\
\text { Discussion } \\
\text { - Strategy 14: Problem- } \\
\text { Based } \\
\text { Learning/Project-Based } \\
\text { Learning } \\
\text { Strategy 26: Lesson } \\
\text { Implementation }\end{array}$ & $\begin{array}{ll}\text { - } & \text { Strategy 7: Examples } \\
\text { - } & \text { Strategy 9: Appropriate } \\
& \text { (Lesson/Learning Activity) } \\
\text { - } & \text { Strategy 2: Exemplars/Models/ } \\
& \text { Experts } \\
\text { - } & \text { Strategy 5: Modeling } \\
\text { - } & \text { Strategy 8: Mentoring/Consultation } \\
\text { - } & \text { Strategy 21: Technology Support } \\
& \text { Teams } \\
\text { - } & \text { Strategy 22: Specific Assessment } \\
& \text { Tool }\end{array}$ \\
\hline
\end{tabular}


Rank of Strategies Used per Indicator (continued)

Indicator 22: use content-specific tools (e.g., software, simulation, web tools) to support learning.

\begin{tabular}{|c|c|c|c|c|}
\hline $\begin{array}{c}\text { Very Often Used } \\
>40\end{array}$ & $\begin{array}{c}\text { Often Used } \\
40-31 \\
\end{array}$ & $\begin{array}{c}\text { Occasionally Used } \\
30-21 \\
\end{array}$ & $\begin{array}{c}\text { Rarely Used } \\
20-11 \\
\end{array}$ & $\begin{array}{c}\text { Very Rarely Used } \\
10-1\end{array}$ \\
\hline None & $\begin{array}{ll}\text { - } & \text { Strategy 6: } \\
\text { Presentation/Demo/ } \\
\text { Hands on }\end{array}$ & $\begin{array}{ll} & \text { Strategy 1: } \\
\text { Identifying/Defining } \\
\text { appropriate use of IT } \\
\text { - } \\
\text { Strategy 9: Appropriate } \\
\text { (Lesson/Learning } \\
\text { Activity) }\end{array}$ & $\begin{array}{ll}\text { - } & \text { Strategy 26: Lesson } \\
\text { Implementation } \\
\text { - } & \text { Strategy 3: } \\
\text { Evaluation/Critique/ } \\
\text { Assessment } \\
\text { - Strategy 8: } \\
\text { Mentoring/Consultation } \\
\text { - Strategy 14: Problem- } \\
\text { Based } \\
\text { Learning/Project-Based } \\
\text { Learning }\end{array}$ & $\begin{array}{ll} & \text { Strategy 2: Exemplars/Models/ } \\
& \text { Experts } \\
\text { - } & \text { Strategy 5: Modeling } \\
\text { - } & \text { Strategy 7: Examples } \\
\text { - } & \text { Strategy 11: Team Work/Group } \\
& \text { Discussion/Peer Discussion } \\
\text { - } & \text { Strategy 20: Made Technology } \\
& \text { Available } \\
\text { - } & \text { Strategy 21: Technology Support } \\
& \text { Teams } \\
\text { - } & \text { Strategy 24: Course/Curriculum } \\
& \text { Modification } \\
\text { - } & \text { Strategy 25: Resources Development } \\
\text { - Strategy 17: Special Funding/Special } \\
\end{array}$ \\
\hline
\end{tabular}

Indicator 23: use technology resources to facilitate knowledge construction.

\begin{tabular}{|c|c|c|c|c|}
\hline $\begin{array}{c}\text { Very Often Used } \\
>\mathbf{4 0}\end{array}$ & $\begin{array}{c}\text { Often Used } \\
40-31 \\
\end{array}$ & $\begin{array}{c}\text { Occasionally Used } \\
30-21 \\
\end{array}$ & $\begin{array}{c}\text { Rarely Used } \\
20-11 \\
\end{array}$ & $\begin{array}{c}\text { Very Rarely Used } \\
10-1 \\
\end{array}$ \\
\hline None & None & $\begin{array}{l}\text { - Strategy 9: Appropriate } \\
\text { (Lesson/Learning } \\
\text { Activity) } \\
\text { - Strategy 1: } \\
\text { Identifying/Defining } \\
\text { appropriate use of IT } \\
\text { - Strategy 6: } \\
\text { Presentation/Demo/ } \\
\text { Hands on }\end{array}$ & $\begin{array}{l}\text { - Strategy 26: Lesson } \\
\text { Implementation } \\
\text { - Strategy 5: Modeling } \\
\text { - Strategy 3: } \\
\text { Evaluation/Critique/ } \\
\text { Assessment } \\
\text { - Strategy 14: Problem- } \\
\text { Based } \\
\text { Learning/Project-Based } \\
\text { Learning }\end{array}$ & $\begin{array}{ll}\text { - } & \text { Strategy 7: Examples } \\
\text { - } & \text { Strategy 11: Team Work/Group } \\
& \text { Discussion/Peer Discussion } \\
\text { - } & \text { Strategy 2: Exemplars/Models/ } \\
& \text { Experts } \\
\text { - } & \text { Strategy 8: Mentoring/Consultation } \\
\text { - } & \text { Strategy 24: Course/Curriculum } \\
& \text { Modification } \\
\text { - } & \text { Strategy 19: Telecollaboration } \\
\text { - } & \text { Strategy 21: Technology Support } \\
& \text { Teams }\end{array}$ \\
\hline
\end{tabular}


Rank of Strategies Used per Indicator (continued)

Indicator 24: apply technology tools and resources to collect, analyze, and interpret data and report results

\begin{tabular}{|c|c|c|c|c|}
\hline $\begin{array}{c}\text { Very Often Used } \\
>40\end{array}$ & $\begin{array}{c}\text { Often Used } \\
40-31\end{array}$ & $\begin{array}{c}\text { Occasionally Used } \\
30-21\end{array}$ & $\begin{array}{c}\text { Rarely Used } \\
20-11\end{array}$ & $\begin{array}{c}\text { Very Rarely Used } \\
10-1\end{array}$ \\
\hline None & $\begin{array}{ll}- & \text { Strategy 3: } \\
\text { Evaluation/Critique/ } \\
\text { Assessment }\end{array}$ & $\begin{array}{l}\text { - Strategy 6: } \\
\text { Presentation/Demo/ } \\
\text { Hands on }\end{array}$ & $\begin{array}{ll}\text { - } & \text { Strategy 22: Specific } \\
& \text { Assessment Tool } \\
\text { - } & \text { Strategy 9: Appropriate } \\
\text { (Lesson/Learning } \\
\text { Activity) } \\
\text { - } & \text { Strategy 26: Lesson } \\
& \text { Implementation }\end{array}$ & $\begin{array}{ll} & \text { Strategy 1: Identifying/Defining } \\
& \text { appropriate use of IT } \\
\text { - } & \text { Strategy 7: Examples } \\
\text { - } & \text { Strategy 8: Mentoring/Consultation } \\
\text { - } & \text { Strategy 23: Faculty Research } \\
& \text { (Presentations/Conferences) } \\
\text { - } & \text { Strategy 2: Exemplars/Models/ } \\
& \text { Experts } \\
\text { - } & \text { Strategy 5: Modeling } \\
\text { - } & \text { Strategy 11: Team Work/Group } \\
& \text { Discussion/Peer Discussion } \\
\text { - } & \text { Strategy 10: Referencing Standard } \\
\text { - } & \text { Strategy 12: Grouping } \\
\text { - } & \text { Strategy 14: Problem- Based } \\
& \text { Learning/Project-Based Learning } \\
\text { - } & \text { Strategy 16: Present/Develop/Use } \\
& \text { Rubrics }\end{array}$ \\
\hline
\end{tabular}


Rank of Strategies Used per Indicator (continued)

Indicator 25: transfer what students' have learned in the classroom to real world situation when planning the use of technology in the classroom(e.g., student-generated recycling program, student-generated business).

\begin{tabular}{|c|c|c|c|c|}
\hline $\begin{array}{c}\text { Very Often Used } \\
>40\end{array}$ & $\begin{array}{c}\text { Often Used } \\
40-31 \\
\end{array}$ & $\begin{array}{c}\text { Occasionally Used } \\
30-21 \\
\end{array}$ & $\begin{array}{c}\text { Rarely Used } \\
20-11 \\
\end{array}$ & $\begin{array}{c}\text { Very Rarely Used } \\
10-1\end{array}$ \\
\hline None & $\begin{array}{l}\text { Strategy 8: } \\
\text { Mentoring/ } \\
\text { Consultation }\end{array}$ & $\begin{array}{ll} & \text { Strategy 5: Modeling } \\
\text { - } & \text { Strategy 6: } \\
\text { Presentation/Demo/ } \\
\text { Hands on } \\
\text { - } \quad \text { Strategy 9: Appropriate } \\
\text { (Lesson/Learning } \\
\text { Activity) } \\
\text { - Strategy 26: Lesson } \\
\text { Implementation }\end{array}$ & $\begin{array}{ll}\text { - } & \text { Strategy 3: } \\
& \text { Evaluation/Critique/ } \\
\text { Assessment } \\
\text { - } & \text { Strategy 7: Examples } \\
\text { - } & \text { Strategy 1: } \\
& \text { Identifying/Defining } \\
\text { appropriate use of IT } \\
\text { - Strategy 2: } \\
\text { Exemplars/Models/ } \\
\text { Experts } \\
\text { - Strategy 14: Problem- } \\
\text { Based } \\
\text { Learning/Project-Based } \\
\text { Learning } \\
\end{array}$ & $\begin{array}{ll}\text { - } & \text { Strategy 10: Referencing Standard } \\
\text { - } & \text { Strategy 11: Team Work/Group } \\
& \text { Discussion/Peer Discussion } \\
\text { - } & \text { Strategy 12: Grouping } \\
\text { - } & \text { Strategy 20: Made Technology } \\
& \text { Available } \\
\text { - } & \text { Strategy 21: Technology Support } \\
& \text { Teams } \\
\text { - Strategy 22: Specific Assessment } \\
\quad \text { Tool }\end{array}$ \\
\hline
\end{tabular}


Rank of Strategies Used per Indicator (continued)

Indicator 26: design online collaborative projects with other entities (e.g., schools, businesses, organizations) to find solutions, make decisions, or seek a resolution to an issue of importance to the students.

\begin{tabular}{|c|c|c|c|c|}
\hline $\begin{array}{c}\text { Very Often Used } \\
>40\end{array}$ & $\begin{array}{c}\text { Often Used } \\
40-31 \\
\end{array}$ & $\begin{array}{c}\text { Occasionally Used } \\
30-21 \\
\end{array}$ & $\begin{array}{c}\text { Rarely Used } \\
20-11 \\
\end{array}$ & $\begin{array}{c}\text { Very Rarely Used } \\
10-1\end{array}$ \\
\hline None & $\begin{array}{ll}\text { - } & \text { Strategy 19: } \\
& \text { Telecollaboration }\end{array}$ & $\begin{array}{ll} & \text { Strategy 5: Modeling } \\
\text { - } & \text { Strategy 6: } \\
& \text { Presentation/Demo/ } \\
& \text { Hands on } \\
\text { - } & \text { Strategy 7: Examples }\end{array}$ & $\begin{array}{l}\text { - Strategy 26: Lesson } \\
\text { Implementation }\end{array}$ & $\begin{array}{ll}\text { - } & \text { Strategy 1: Identifying/Defining } \\
\text { appropriate use of IT } \\
\text { - } \\
\text { Strategy 3: Evaluation/Critique/ } \\
\text { Assessment } \\
\text { - } \quad \text { Strategy 8: Mentoring/Consultation } \\
\text { - } \quad \text { Strategy 9: Appropriate } \\
\text { (Lesson/Learning Activity) } \\
\text { - Strategy 18: Collaborative Learning } \\
\text { - Strategy 20: Made Technology } \\
\text { Available } \\
\text { - Strategy 21: Technology Support } \\
\text { Teams } \\
\text { - Strategy 22: Specific Assessment } \\
\text { Tool } \\
\end{array}$ \\
\hline
\end{tabular}


Rank of Strategies Used per Indicator (continued)

Indicator 27: use technology in instruction to provide students with increased levels of interactivity.

\begin{tabular}{|c|c|c|c|c|}
\hline $\begin{array}{c}\text { Very Often Used } \\
>40\end{array}$ & $\begin{array}{c}\text { Often Used } \\
40-31\end{array}$ & $\begin{array}{c}\text { Occasionally Used } \\
30-21\end{array}$ & $\begin{array}{c}\text { Rarely Used } \\
20-11\end{array}$ & $\begin{array}{c}\text { Very Rarely Used } \\
10-1\end{array}$ \\
\hline None & None & None & $\begin{array}{ll}\text { - } & \text { Strategy 1: } \\
& \text { Identifying/Defining } \\
& \text { appropriate use of IT } \\
\text { - } & \text { Strategy 9: Appropriate } \\
& \text { (Lesson/Learning } \\
& \text { Activity) } \\
\text { - } & \text { Strategy 5: Modeling } \\
\text { - } & \text { Strategy 7: Examples } \\
\text { - } & \text { Strategy 19: } \\
& \text { Telecollaboration } \\
\text { - } & \text { Strategy 14: Problem- } \\
& \text { Based } \\
& \text { Learning/Project-Based } \\
& \text { Learning } \\
\text { - Strategy 26: Lesson } \\
\text { Implementation }\end{array}$ & $\begin{array}{ll}\text { - } & \text { Strategy 11: Team Work/Group } \\
\text { Discussion/Peer Discussion } \\
\text { - Strategy 2: Exemplars/Models/ } \\
\text { Experts } \\
\text { - Strategy 3: Evaluation/Critique/ } \\
\text { Assessment } \\
\text { - Strategy 6: Presentation/Demo/ } \\
\text { Hands on } \\
\text { - Strategy 8: Mentoring/Consultation } \\
\text { - Strategy 12: Grouping } \\
\text { - Strategy 18: Collaborative Learning } \\
\text { - Strategy 24: Course/Curriculum } \\
\text { Modification }\end{array}$ \\
\hline
\end{tabular}




\section{APPENDIX M}

RANK OF STRATEGIES USE ACROSS INDICATORS AND INDICATORS ADDRESSED

BY EACH STRATEGY 
Rank of Strategies Use Across Indicators and Indicators Addressed by Each Strategy

\begin{tabular}{|c|c|c|c|c|c|c|c|}
\hline \multirow{2}{*}{$\begin{array}{c}\text { Strategies Most Often Used } \\
\text { Across Indicators } \\
\text { First Quartile: } 78-60 \\
\end{array}$} & \multicolumn{7}{|c|}{ Indicators in which the most often used strategies appear in each of the five levels of use ${ }^{\epsilon}$} \\
\hline & 5 & 4 & 3 & 2 & 1 & & 0 \\
\hline $\begin{array}{l}\text { Strategy 9: } \\
\text { Appropriate (Lesson/Learning } \\
\text { Activity) Development }\end{array}$ & $\begin{array}{l}2,3,4,6,8,14, \\
20\end{array}$ & 7,18 & $\begin{array}{l}1,12,15,19,22 \\
23,25\end{array}$ & $5,11,17,24,27$ & $10,16,21,26$ & 9,13 & \\
\hline $\begin{array}{l}\text { Strategy 6: } \\
\text { Presentation/Demo/Hands on }\end{array}$ & 0 & $15,19,22$ & $\begin{array}{l}1,2,23,24,25, \\
26\end{array}$ & $\begin{array}{l}3,4,6,7,8,9,10, \\
11,12,13,14,16, \\
17,18,20,21\end{array}$ & 5,27 & 0 & \\
\hline $\begin{array}{l}\text { Strategy 1: } \\
\text { Identifying/Defining } \\
\text { Appropriate Use of IT }\end{array}$ & 1,2 & 0 & $\begin{array}{l}13,14,, 15,16 \\
17,21,22,23\end{array}$ & $\begin{array}{l}3,4,6,8,11,12 \\
18,19,25,27\end{array}$ & $\begin{array}{l}5,7,9,10,20,24, \\
26\end{array}$ & 0 & \\
\hline
\end{tabular}


Rank of Strategies Use Across Indicators and Indicators Addressed by Each Strategy (continued)

\begin{tabular}{|c|c|c|c|c|c|c|}
\hline \multirow{2}{*}{$\begin{array}{l}\text { Strategies Often Used Across } \\
\text { Indicators } \\
\text { Second Quartile: } 59-41\end{array}$} & \multicolumn{6}{|c|}{ Indicators in which the often used strategies appear in each of the five levels of use ${ }^{\epsilon}$} \\
\hline & 5 & 4 & 3 & 2 & 1 & 0 \\
\hline $\begin{array}{l}\text { Strategy 3: } \\
\text { Evaluation/Critique/Assessment }\end{array}$ & 0 & $1,2,5,9,24$ & $3,7,8,19$ & $\begin{array}{l}4,6,12,14,16,19, \\
25\end{array}$ & $\begin{array}{l}11,15,17,20,26, \\
27\end{array}$ & 10 \\
\hline $\begin{array}{l}\text { Strategy 14: } \\
\text { Problem- Based Learning/ } \\
\text { Project-Based Learning }\end{array}$ & 20 & 12 & 14,19 & $\begin{array}{l}2,3,6,17,18,21 \\
22,23,25,27\end{array}$ & $\begin{array}{l}1,4,5,7,8,13 \\
15,16\end{array}$ & $9,10,11,26$ \\
\hline $\begin{array}{l}\text { Strategy } 26: \\
\text { Lesson implementation }\end{array}$ & 0 & 0 & 25 & $\begin{array}{l}2,3,4,5,7,8,14 \\
15,18,20,21,22 \\
23,24,26,27\end{array}$ & $\begin{array}{l}1,6,9,12,13,16 \\
17,19\end{array}$ & 10,11 \\
\hline
\end{tabular}

${ }^{€}$ Level of Use: 5 Very Often Used, 4 Often Used, 3 Occasionally Used, 2 Rarely Used, 1 Very Rarely Used, and 0 Never Used 
Rank of Strategies Use Across Indicators and Indicators Addressed by Each Strategy (continued)

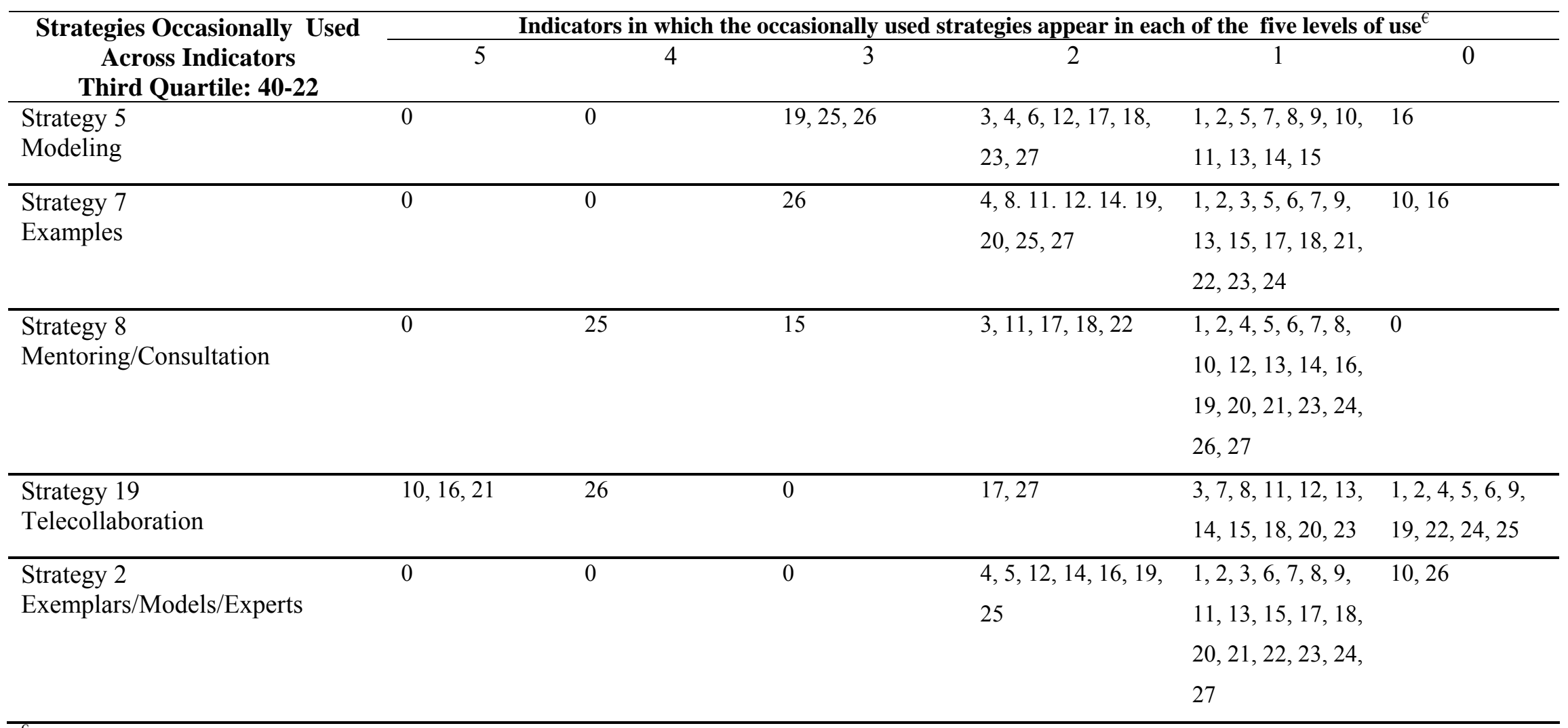

\footnotetext{
${ }^{€}$ Level of Use: 5 Very Often Used, 4 Often Used, 3 Occasionally Used, 2 Rarely Used, 1 Very Rarely Used, and 0 Never Used
} 
Rank of Strategies Use Across Indicators and Indicators Addressed by Each Strategy (continued)

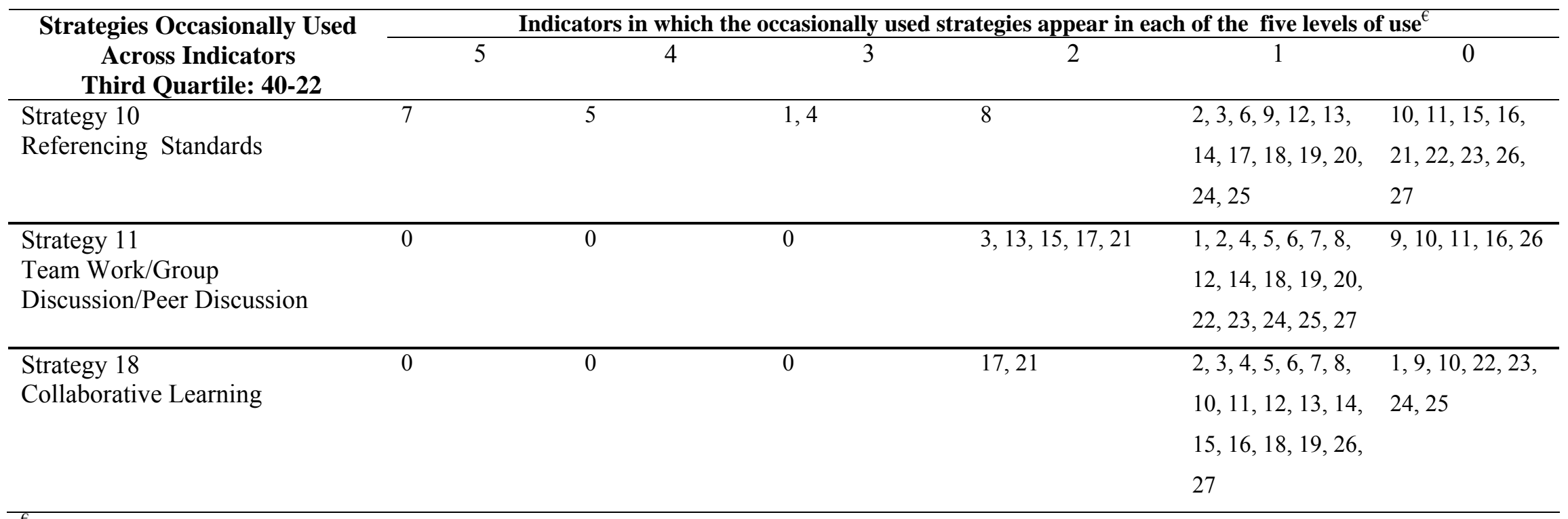

${ }^{€}$ Level of Use: 5 Very Often Used, 4 Often Used, 3 Occasionally Used, 2 Rarely Used, 1 Very Rarely Used, and 0 Never Used 
Rank of Strategies Use Across Indicators and Indicators Addressed by Each Strategy (continued)

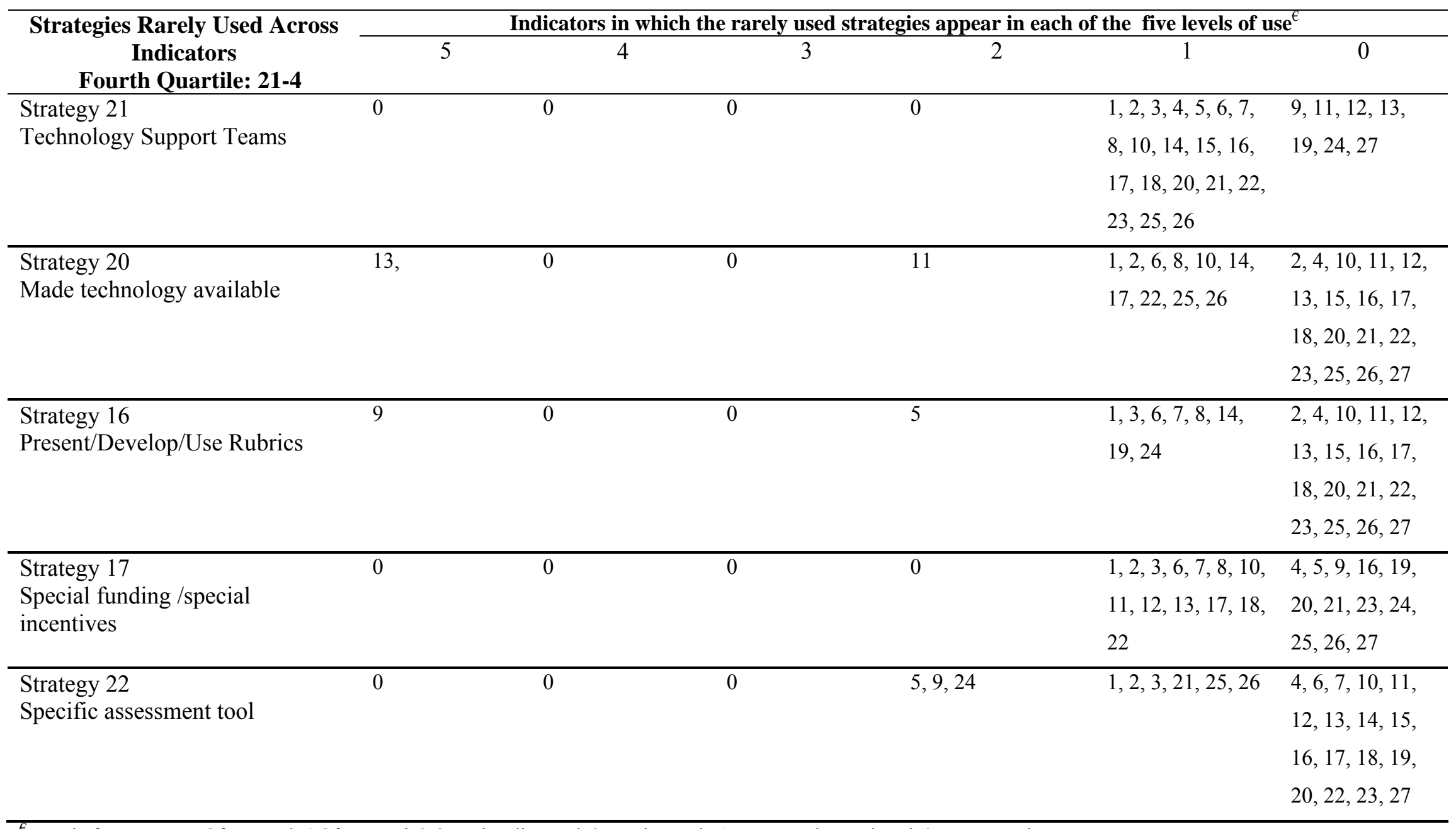

${ }^{€}$ Level of Use: 5 Very Often Used, 4 Often Used, 3 Occasionally Used, 2 Rarely Used, 1 Very Rarely Used, and 0 Never Used 
Rank of Strategies Use Across Indicators and Indicators Addressed by Each Strategy (continued)

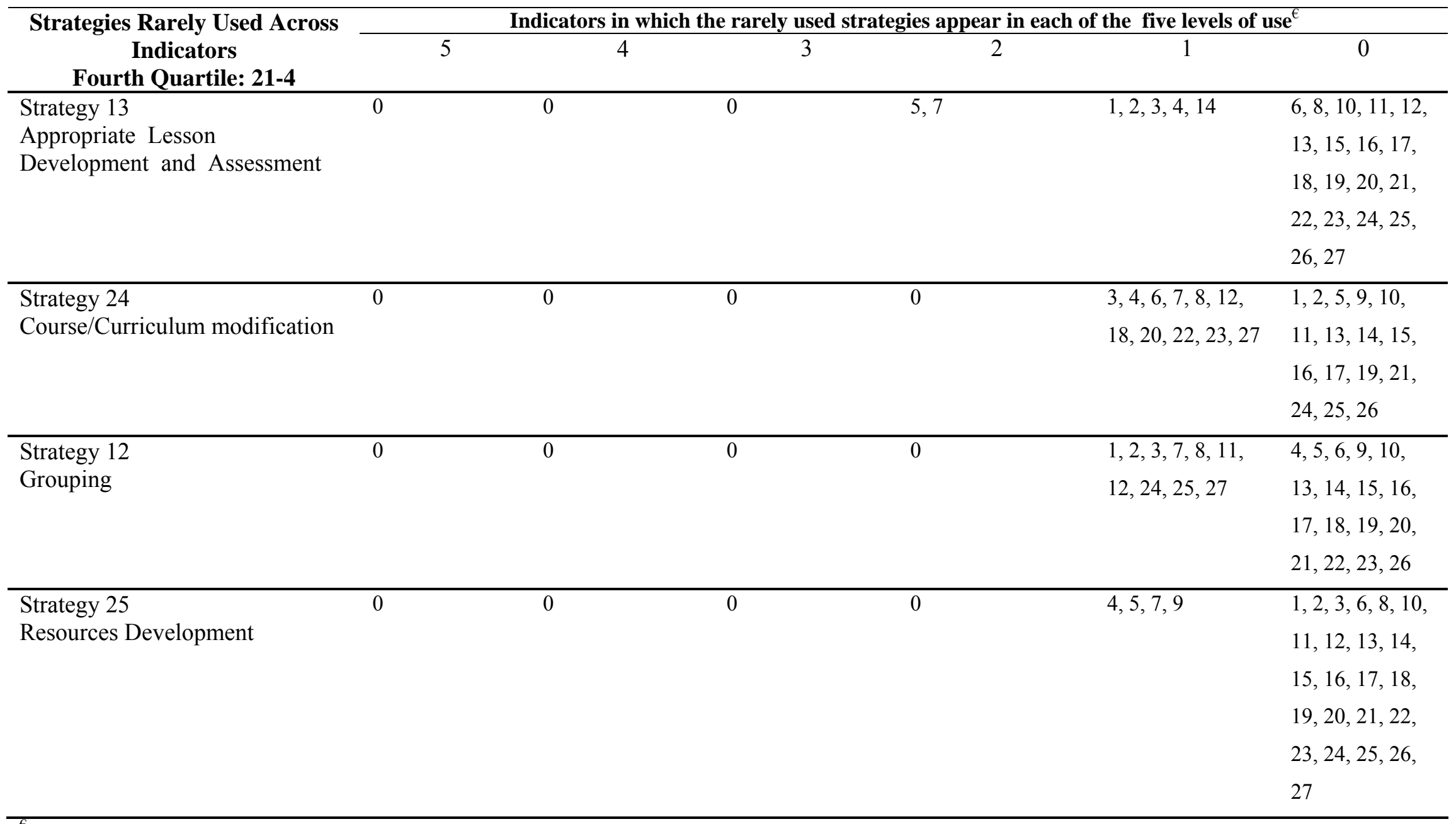

${ }^{€}$ Level of Use: 5 Very Often Used, 4 Often Used, 3 Occasionally Used, 2 Rarely Used, 1 Very Rarely Used, and 0 Never Used 
Rank of Strategies Use Across Indicators and Indicators Addressed by Each Strategy (continued)

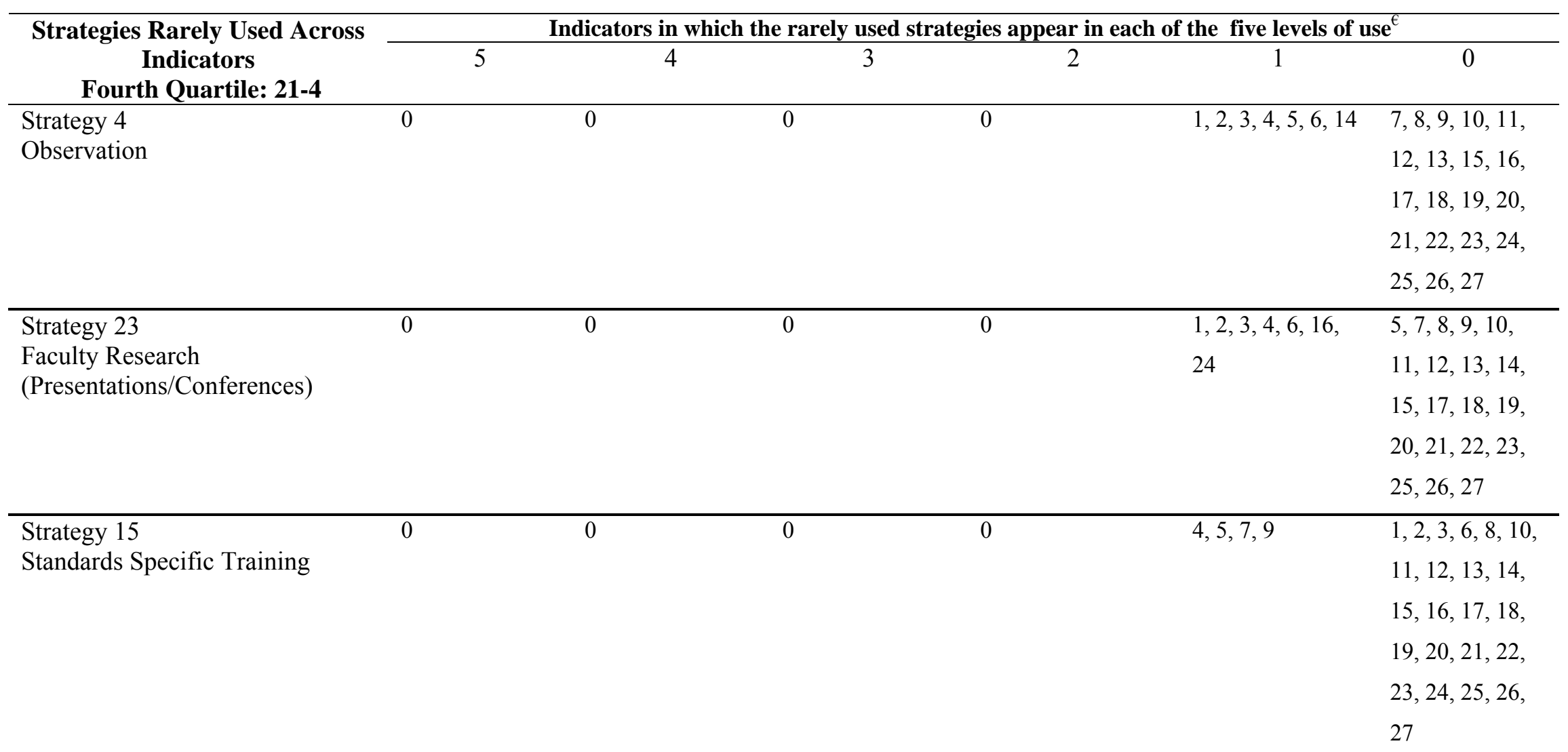

${ }^{\epsilon}$ Level of Use: 5 Very Often Used, 4 Often Used, 3 Occasionally Used, 2 Rarely Used, 1 Very Rarely Used, and 0 Never Used 
APPENDIX N

DESCRIPTION OF THE MOST USED STRATEGIES ACROSS INDICATORS 


\section{Strategy 9: Appropriate (Lesson/Learning Activity) Development.}

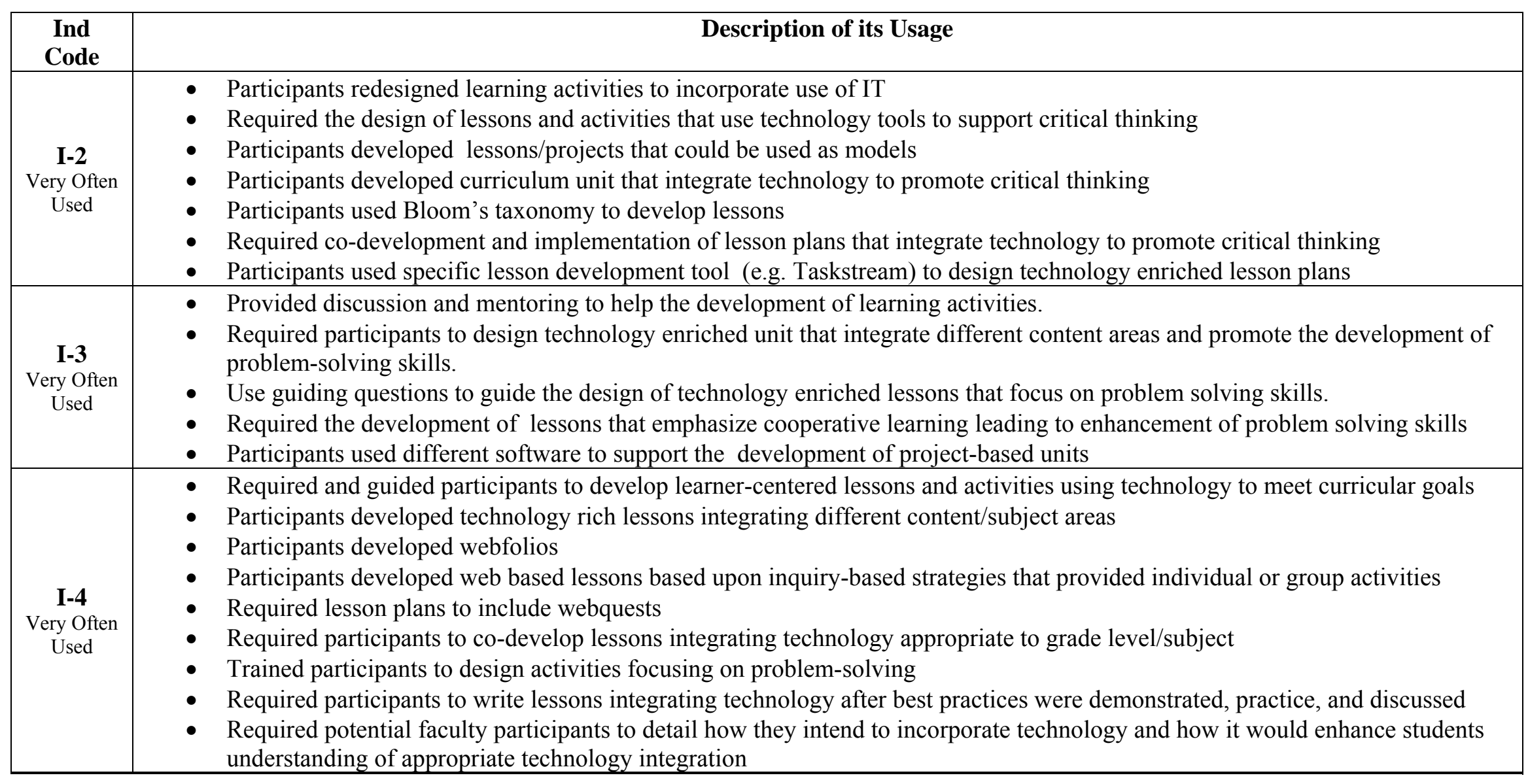


Description of the Most Used Strategies Used Across Indicators (continued)

\section{Strategy 9: Appropriate (Lesson/Learning Activity) Development (continued)}

\begin{tabular}{|c|c|}
\hline $\begin{array}{l}\text { Ind } \\
\text { Code }\end{array}$ & Description of its Usage \\
\hline $\begin{array}{c}\text { I-6 } \\
\text { Very Often } \\
\text { Used }\end{array}$ & $\begin{array}{l}\text { - Required participants to develop student-centered project-based lesson plans } \\
\text { - Required the inclusion of the development of webfolios in their lesson plans } \\
\text { - Participants developed webquest units and webpages addressing curriculum goals } \\
\text { - Required participants to develop online and classroom learning materials } \\
\text { - Participants developed lessons or learning activities that included online research and/or construction of presentations using } \\
\text { - technology } \\
\text { - Participants developed technology enriched lessons with the help of experts on their subject } \\
\text { - Required participants to develop e-portfolios and include it as part of their lesson plans }\end{array}$ \\
\hline $\begin{array}{c}\mathbf{I - 8} \\
\text { Very Often } \\
\text { Used }\end{array}$ & $\begin{array}{l}\text { - Required participants to design technology-enriched learning activities that addressed students individual needs } \\
\text { - Participants developed on-line self-pacing materials that addressed students' needs } \\
\text { - Provided examples that could be used to inspire the development of technology-enriched lesson } \\
\text { - Required participants to develop an e-portfolio and include it as part of their lesson plans } \\
\text { - Required participants to write mini-lessons about each module (e.g. desktop publishing, spreadsheets, multi-media, etc). In each } \\
\text { mini-lesson, the student is required to describe a special population - such as sight-impaired, dyslexic, etc, and then to describe } \\
\text { how technology can be used to help that student } \\
\text { - Provided guidelines for the development of technology-enriched learning activities } \\
\text { - Required participants developed project-based learning activities }\end{array}$ \\
\hline
\end{tabular}


Description of the Most Used Strategies Used Across Indicators (continued)

\section{Strategy 9: Appropriate (Lesson/Learning Activity) Development (continued)}

\begin{tabular}{|c|c|}
\hline $\begin{array}{c}\text { Ind } \\
\text { Code }\end{array}$ & Description of its Usage \\
\hline $\begin{array}{c}\mathbf{I}-\mathbf{2 0} \\
\text { Very Often } \\
\text { Used }\end{array}$ & $\begin{array}{l}\text { - } \quad \text { Participants developed lesson plans that included virtual field trips } \\
\text { - } \quad \text { Participants developed learning activities that focus on webquest } \\
\text { - } \quad \text { Participants created their own course oriented web pages } \\
\text { - } \quad \text { Participants used Harris' activity structures to develop learning activities } \\
\text { - } \quad \text { Participants used Bloom's taxonomy to develop technology-enriched lessons }\end{array}$ \\
\hline $\begin{array}{c}\text { I-7 } \\
\text { Often Used }\end{array}$ & $\begin{array}{l}\text { - Required participants to develop technology enriched lesson plans, and online materials that support content specific curriculum } \\
\text { goals } \\
\text { - } \text { Participants developed webquest units and webpages addressing curriculum goals } \\
\text { - } \quad \text { Required participants to identify ISTE National Educational Technology Standards for Students and Teachers and develop } \\
\text { lesson plans that would address them. } \\
\text { - } \text { Required participants to include a technology standard in their syllabus that matches the academic the academic state and } \\
\text { - } \text { national standards } \\
\text { - } \text { Required participants to develop units that integrate technology and meet curriculum, state, and national goals } \\
\text { - } \text { Required participants to develop an e-portfolio and include it as part of their lesson plans }\end{array}$ \\
\hline $\begin{array}{c}\text { I-18 } \\
\text { Often Used }\end{array}$ & $\begin{array}{l}\text { - Participants created a technology fair based on a motivational theme that provided activities that involved students in exploring } \\
\text { both technology and how the technology supports curricular goals. } \\
\text { - Supported the development of technology enriched lesson plans that considered students' learning objectives and students' } \\
\text { motivation and interests, and adjust to the special interest of students. } \\
\text { - The Participants created webpages that addressed learning needs } \\
\text { - } \text { Encouraged the development of lesson plans that focused on the use of content-based technology that support students creative } \\
\text { work }\end{array}$ \\
\hline
\end{tabular}




\section{Strategy 9: Appropriate (Lesson/Learning Activity) Development (continued)}

\begin{tabular}{|c|c|}
\hline $\begin{array}{l}\text { I-1 } \\
\text { Occasionally } \\
\text { Used }\end{array}$ & $\begin{array}{l}\text { - Participants designed curriculum units that integrate technology in the different content/subject areas } \\
\text { - Participants designed lessons, webquest, and webpages to further implementation in their classrooms } \\
\text { - Participants developed curriculum unit that integrate technology } \\
\text { - Required participants to complete a set of assignments to demonstrate their understanding of appropriate and inappropriate use } \\
\text { - of technology }\end{array}$ \\
\hline $\begin{array}{l}\text { I-15 } \\
\text { Occasionally } \\
\text { Used }\end{array}$ & $\begin{array}{l}\text { - Required the development of technology-enriched lesson plans } \\
\text { - Participants developed lesson plans that required students to research their culture via Internet seeking databases throughout the } \\
\text { country } \\
\text { - } \text { Required participants to develop learning activities within their content areas }\end{array}$ \\
\hline $\begin{array}{c}\text { I-22 } \\
\text { Occasionally } \\
\text { Used }\end{array}$ & $\begin{array}{l}\text { - Participants developed activities that used specific content related software to support learning goals } \\
\text { - Participants developed technology-enriched lesson plans to address their content area } \\
\text { - Participants developed web sites to support curriculum goals }\end{array}$ \\
\hline \begin{tabular}{c|}
$\mathbf{I}-23$ \\
Occasionally \\
Used
\end{tabular} & $\begin{array}{l}\text { - Used Inspiration to guide participants to develop technology-enriched learning activities } \\
\text { - Participants developed webfolios and were asked to design lessons that incorporate the use of webfolios }\end{array}$ \\
\hline \begin{tabular}{c|c}
$\mathbf{I}-25$ \\
Occasionally \\
Used
\end{tabular} & - Participants selected technology based activities to integrate in their lesson plans \\
\hline
\end{tabular}




\section{Strategy 6: Presentation/Demo/Hands on}

\begin{tabular}{|c|c|}
\hline $\begin{array}{l}\text { Ind } \\
\text { Code }\end{array}$ & Description of its Usage \\
\hline $\begin{array}{c}\text { I-19 } \\
\text { Often Used }\end{array}$ & $\begin{array}{l}\text { - Specific training on evaluation strategies } \\
\text { - } \quad \text { Group workshops with experts in the area }\end{array}$ \\
\hline $\begin{array}{c}\text { I-22 } \\
\text { Often Used }\end{array}$ & $\begin{array}{l}\text { - } \text { Group workshops with experts in the area } \\
\text { - Presentation of technology tools and hands-on training on their use } \\
\text { - Training in content-specific instructional technology tools } \\
\text { - } \quad \text { Provided skills development workshops }\end{array}$ \\
\hline $\begin{array}{c}\text { I-1 } \\
\text { Occasionally } \\
\text { Used }\end{array}$ & $\begin{array}{l}\text { - } \text { Group workshops with experts in the area } \\
\text { - } \quad \text { Presentation and review of available software and hardware. } \\
\text { - Trained participants to use content-based software } \\
\text { - } \text { On-site training sessions } \\
\text { - Engaged participants in activities and projects related to appropriate integration of technology into instructional units } \\
\text { - Invited outside guest speakers as part of the training } \\
\text { - Summer workshops } \\
\text { - Required participants to complete technology driven program } \\
\text { - Provided specific training to participants on instructional technologies that they chose as relevant to their teaching area } \\
\text { - Taught participants on different levels of technology integration: Low (fundamental use of an application), middle (application } \\
\text { of technology to teaching, e.g. Powerpoint presentations) and high (building webquests). }\end{array}$ \\
\hline $\begin{array}{c}\mathbf{I}-\mathbf{2} \\
\text { Occasionally } \\
\text { Used }\end{array}$ & $\begin{array}{l}\text { - Group workshops demonstrating technology that supported critical thinking } \\
\text { - Conduct workshops on the use of communication technologies that enhanced distance learning opportunities } \\
\text { - Group workshops on specific theme with experts in the area. } \\
\text { - Presentation and review of available software and hardware } \\
\text { - Taught technology skills as lessons } \\
\text { - Sessions on the use of webquest to promote critical thinking } \\
\text { - Introduction to content-related software and learning activities }\end{array}$ \\
\hline
\end{tabular}


Description of the Most Used Strategies Used Across Indicators (continued)

\section{Strategy 6: Presentation/Demo/Hands on (continued)}

\begin{tabular}{|c|c|}
\hline $\begin{array}{l}\text { Ind } \\
\text { Code }\end{array}$ & Description of its Usage \\
\hline $\begin{array}{l}\text { I-23 } \\
\text { Occasionally } \\
\text { Used }\end{array}$ & $\begin{array}{l}\text { - } \text { Group workshops with experts in the area } \\
\text { - } \quad \text { Presentation and review of available software and hardware } \\
\text { - } \quad \text { Taught the use of PDAs in the classroom } \\
\text { - } \quad \text { Training in specific software applications: web authoring software, video editing, and concept map. } \\
\text { - }\end{array}$ \\
\hline $\begin{array}{l}\text { I-24 } \\
\text { Occasionally } \\
\text { Used }\end{array}$ & $\begin{array}{l}\text { - } \text { Training on spreadsheet } \\
\text { - } \quad \text { Group workshop on content-specific software } \\
\text { - } \quad \text { Content specific workshops } \\
\text { - } \quad \text { Required participants to complete technology driven program }\end{array}$ \\
\hline $\begin{array}{l}\text { I-25 } \\
\text { Occasionally } \\
\text { Used }\end{array}$ & $\begin{array}{l}\text { - Group workshops with experts in the area } \\
\text { - Offered workshops sessions on specific technology-content related topics, e.g,, Intro to Palm Pilots, Powerpoint, How to Create } \\
\text { a Website.. }\end{array}$ \\
\hline $\begin{array}{c}\mathbf{I - 2 6} \\
\text { Occasionally } \\
\text { Used } \\
\end{array}$ & - Group workshops with experts in the area \\
\hline
\end{tabular}


Description of the Most Used Strategies Used Across Indicators (continued)

Strategy 1: Identifying/Defining Appropriate Use of IT

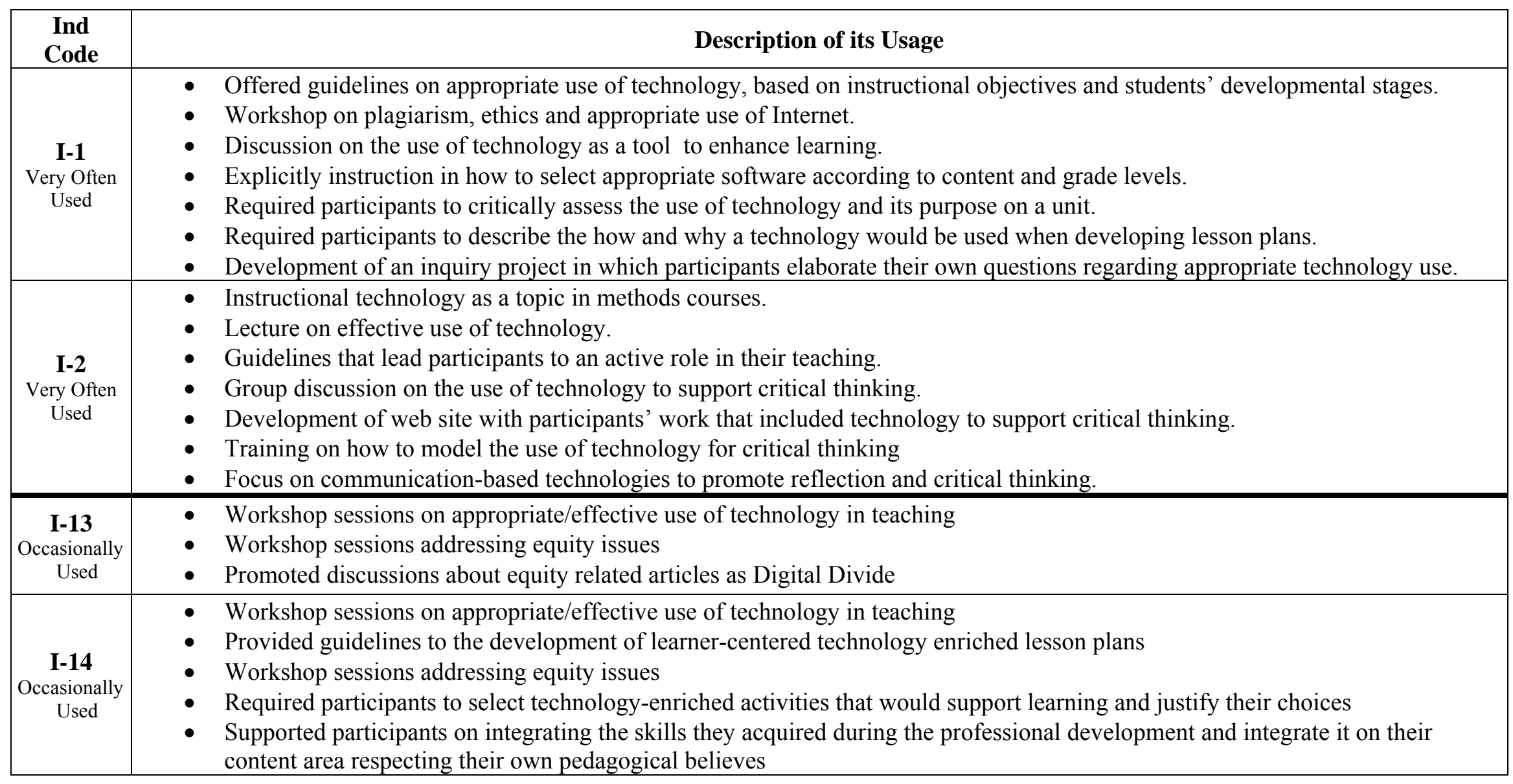




\section{Strategy 1: Identifying/Defining Appropriate Use of IT (continued)}

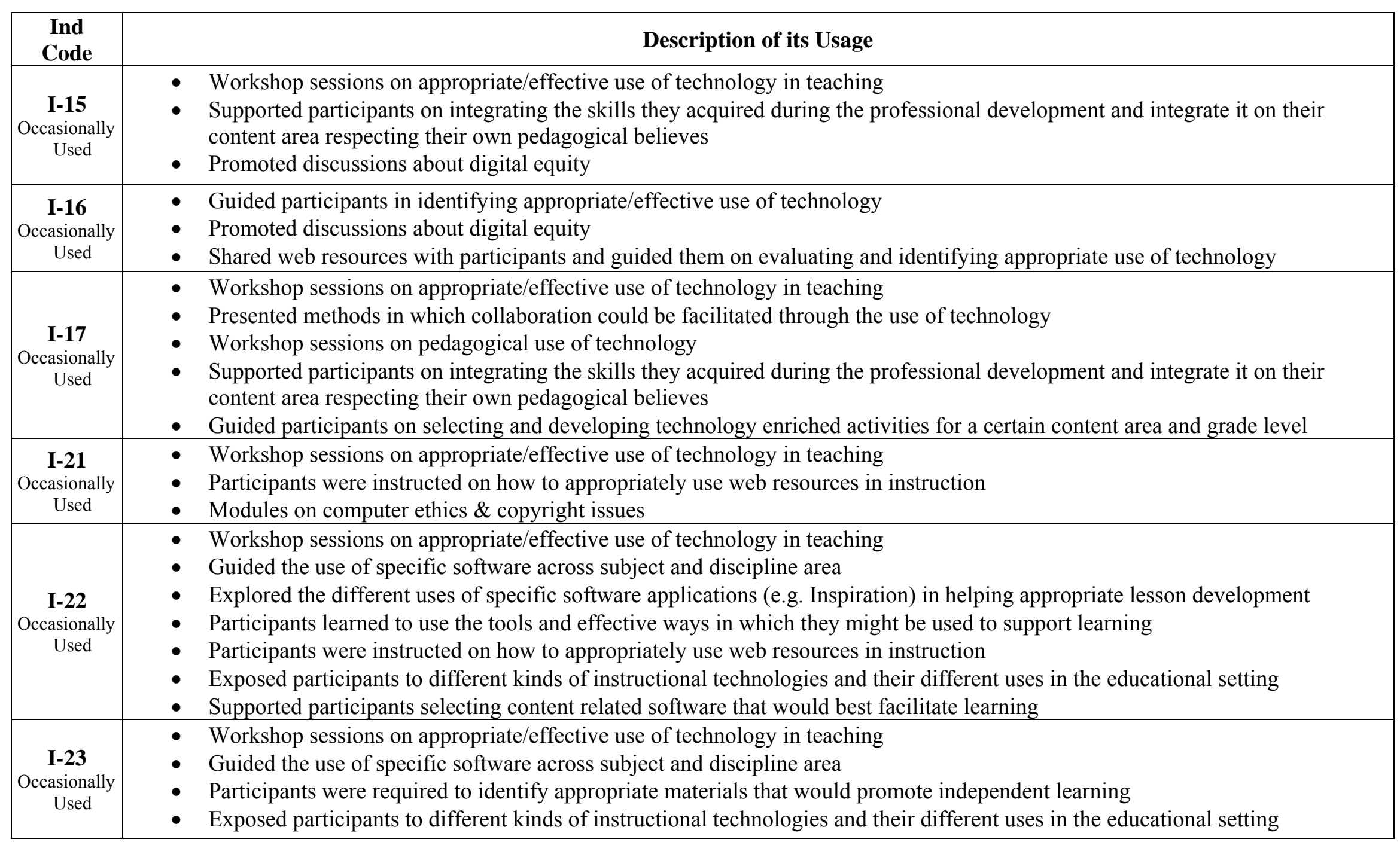


Description of the Most Used Strategies Used Across Indicators (continued)

\section{Strategy 3: Evaluation/Critique/Assessment}

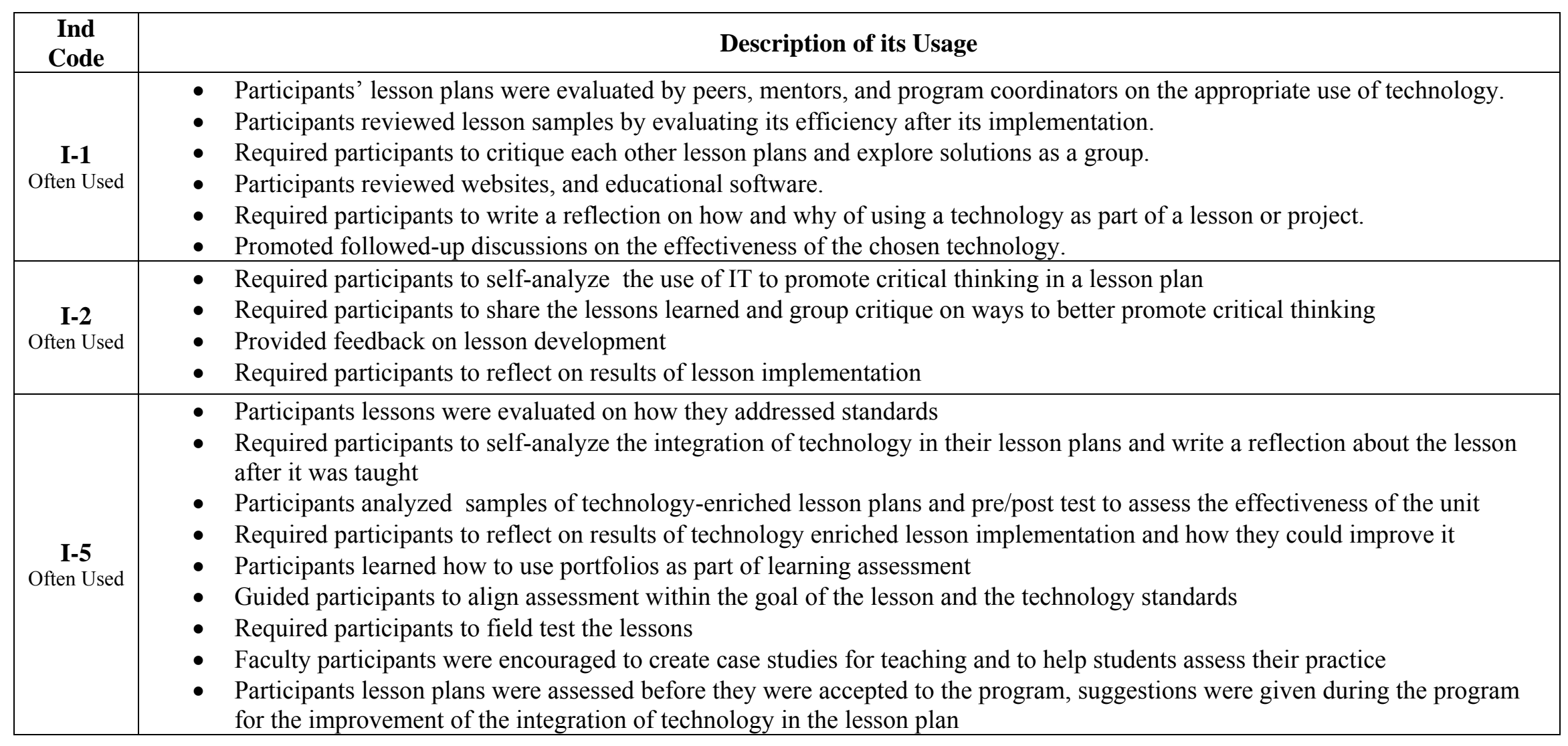


Description of the Most Used Strategies Used Across Indicators (continued)

\section{Strategy 3: Evaluation/Critique/Assessment (continued)}

\begin{tabular}{|c|c|}
\hline $\begin{array}{c}\text { Ind } \\
\text { Code }\end{array}$ & Description of its Usage \\
\hline $\begin{array}{c}\text { I-9 } \\
\text { Often Used }\end{array}$ & $\begin{array}{l}\text { - Participants lessons were evaluated on how they addressed standards } \\
\text { - Discussed in workshops the importance of evaluating the process as well as the products during instructional time with } \\
\text { technology } \\
\text { - Required participants to design and develop a webfolio assessment system that allowed for multiple measurement options } \\
\text { - Integrated a matrix to evaluate lesson plans for assessing multiple learning and teaching strategies based on Gardner's theory } \\
\text { and others mainly Vygotsky } \\
\text { Required participants to generate a teaching webfolio to demonstrate their learning. The webfolio are jointly reviewed by the } \\
\text { programs experts }\end{array}$ \\
\hline $\begin{array}{c}\mathbf{I}-\mathbf{2 4} \\
\text { Often Used }\end{array}$ & $\begin{array}{l}\text { - Required participants to self-analyze the integration of technology in their lesson plans and write a reflection about the lesson } \\
\text { after it was taught } \\
\text { - Required participants to design and develop a webfolio assessment system that allowed for multiple measurement options } \\
\text { - Made available to participants online quiz and report generators that tested participants' students progress and provided report } \\
\text { to participants } \\
\text { - Participants used specific software (e.g. Excel, SPSS) to collect, interpret data from eight schools and evaluate which school } \\
\text { was a best match for them } \\
\text { Used Profiler tool to measure participants' technology development }\end{array}$ \\
\hline
\end{tabular}


Description of the Most Used Strategies Used Across Indicators (continued)

\section{Strategy 3: Evaluation/Critique/Assessment (continued)}

\begin{tabular}{|c|c|}
\hline $\begin{array}{c}\text { Ind } \\
\text { Code }\end{array}$ & Description of its Usage \\
\hline $\begin{array}{c}\mathbf{I}-\mathbf{1 9} \\
\text { Occasionally } \\
\text { Used }\end{array}$ & $\begin{array}{l}\text { - Required participants to self-analyze the integration of technology in their lesson plans and write a reflection about the lesson } \\
\text { after it was taught } \\
\text { - Participants technology integrated lessons were evaluated by peers and program coordinators } \\
\text { - Participants analyzed web sites and software packages on the basis of promoting higher order thinking skills }\end{array}$ \\
\hline
\end{tabular}




\section{Strategy 14: Problem- Based Learning/ Project-Based Learning}

\begin{tabular}{|c|c|}
\hline $\begin{array}{l}\text { Ind } \\
\text { Code }\end{array}$ & Description of its Usage \\
\hline $\begin{array}{c}\mathbf{I - 1 2} \\
\text { Often Used }\end{array}$ & $\begin{array}{l}\text { - Required participants to develop content related projects (e.g. AIDS project) in which students do research online and use } \\
\text { technology to share and report the results } \\
\text { - Participants focused on the design of webquest related to the subject area } \\
\text { - Required participants to complete online case-based problem solving exercises individually and then discuss and collaborate on } \\
\text { their answers before moving to the next case } \\
\text { - Encouraged and trained participants on the use of Thinkquest in the subject area }\end{array}$ \\
\hline $\begin{array}{c}\mathbf{I}-14 \\
\text { Occasionally } \\
\text { Used }\end{array}$ & $\begin{array}{l}\text { - Participants are exposed to webquests and include it in their lesson plans } \\
\text { - Required participants to design project based activities and include in their lesson plans } \\
\text { - Trained participants on Thinkquest and the development of digital storytelling projects } \\
\text { - Required participants to conduct a case study on extended inquiry projects with the purpose of analyzing how extended inquiry } \\
\text { projects are designed, developed and implemented }\end{array}$ \\
\hline
\end{tabular}

\section{Strategy 26: Lesson Implementation}

\begin{tabular}{|c|cl|}
\hline $\begin{array}{c}\text { Ind } \\
\text { Code }\end{array}$ & & Description of its Usage \\
\hline $\begin{array}{c}\text { I-25 } \\
\text { Occasionally } \\
\text { Used }\end{array}$ & $\bullet$ & Required participants to field test their technology infused lesson plans testing their lesson plan in a real world setting \\
\hline
\end{tabular}


APPENDIX O

DESCRIPTION OF THE OCCASIONALLY USED STRATEGIES ACROSS INDICATORS 
Description of the Occasionally Used Strategies across Indicators

\section{Strategy 5: Modeling}

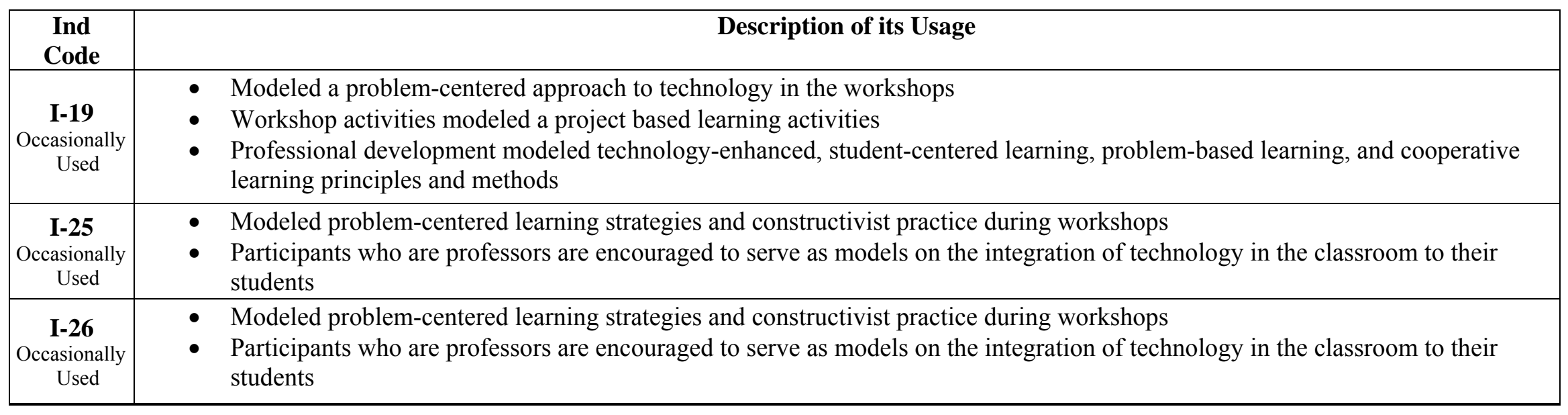

\section{Strategy 7: Examples}

\begin{tabular}{|c|cl|}
\hline $\begin{array}{c}\text { Ind } \\
\text { Code }\end{array}$ & & \\
\hline $\begin{array}{c}\text { I-26 } \\
\text { Occasionally } \\
\text { Used }\end{array}$ & $\bullet$ & $\begin{array}{l}\text { Required participants to share their technology enriched lesson plans/activities with the other participants } \\
\text { As a follow-up to the training sessions, special sessions were scheduled for participants to share projects and ideas about how } \\
\text { they were applying what they learned in the training sessions }\end{array}$ \\
\hline
\end{tabular}


Description of the Occasionally Used Strategies across Indicators (continued)

\section{Strategy 8: Mentoring/Consultation}

\begin{tabular}{|c|c|}
\hline $\begin{array}{l}\text { Ind } \\
\text { Code }\end{array}$ & Description of its Usage \\
\hline $\begin{array}{c}\text { I-25 } \\
\text { Often Used }\end{array}$ & $\begin{array}{l}\text { - } \text { Participants were coached on appropriate/effective incorporation of technology in teaching } \\
\text { - Mentor participants in-site guiding them on ways to better integrate technology in their subject area } \\
\text { - } \quad \text { Participants could individually discuss with their mentors the application of technology in their unit } \\
\text { - } \quad \text { Participants mentored the teachers from the schools they were placed on how to integrate technology in their classroom }\end{array}$ \\
\hline $\begin{array}{c}\mathbf{I - 1 5} \\
\text { Occasionally } \\
\text { Used }\end{array}$ & $\begin{array}{l}\text { - Participants were coached on appropriate/effective incorporation of technology in teaching } \\
\text { - Technology consultants were available to work on one-one mentoring. } \\
\text { - Placed an experienced classroom teacher working full time for the project, and serving as a consultant for teachers on the } \\
\text { integration of technology into their classrooms } \\
\text { - Provided a center that included a highly trained staff where participants could get individual help on the integration of } \\
\text { - } \quad \text { Prochnology into their units }\end{array}$ \\
\hline
\end{tabular}




\section{Strategy 19: Telecollaboration}

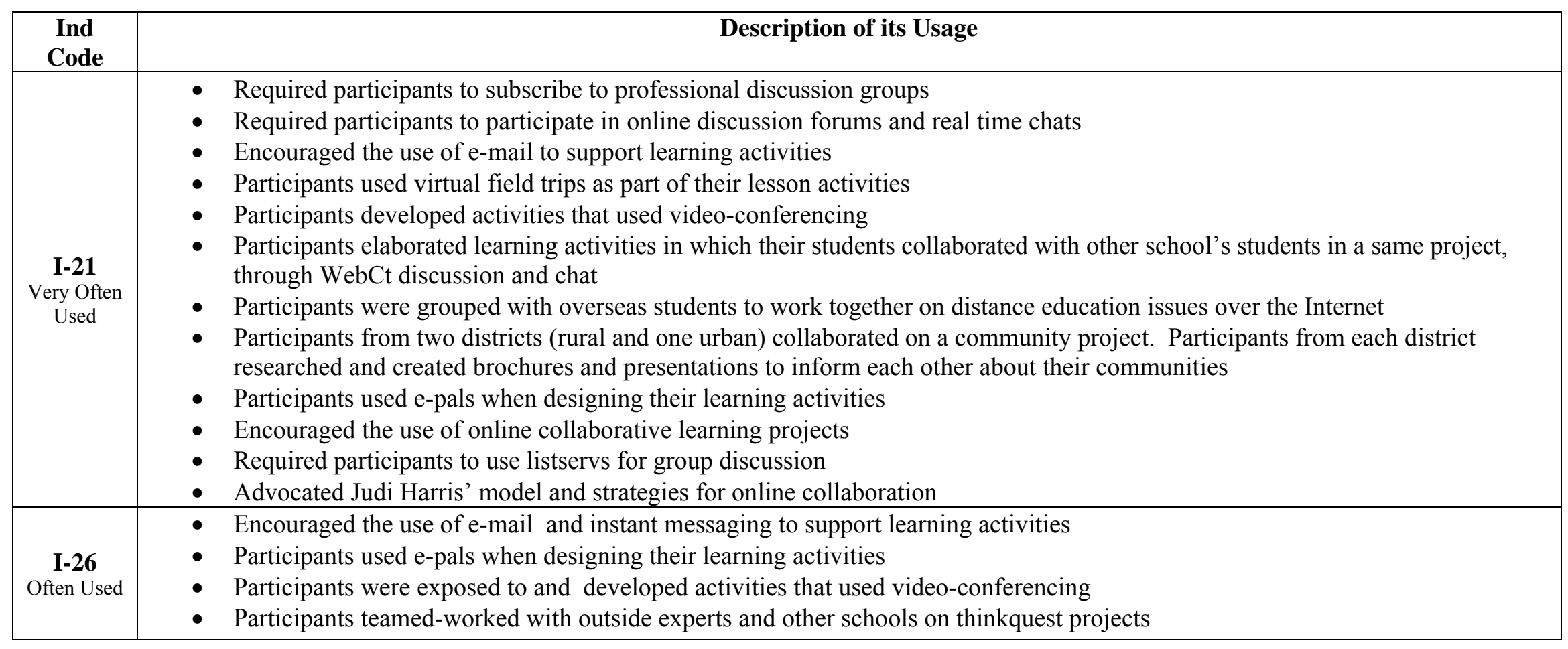

\section{Strategy 2: Exemplars/Models/Experts}

\begin{tabular}{|c|c|}
\hline $\begin{array}{c}\text { Ind } \\
\text { Code }\end{array}$ & \multicolumn{1}{c|}{ Description of its Usage } \\
\hline & $\begin{array}{l}\text { This strategy did not have any indicator in which it was highly used, but this strategy was present in almost all the } \\
\text { indicators in some degree }\end{array}$ \\
\hline
\end{tabular}




\section{Strategy 10: Referencing Standards}

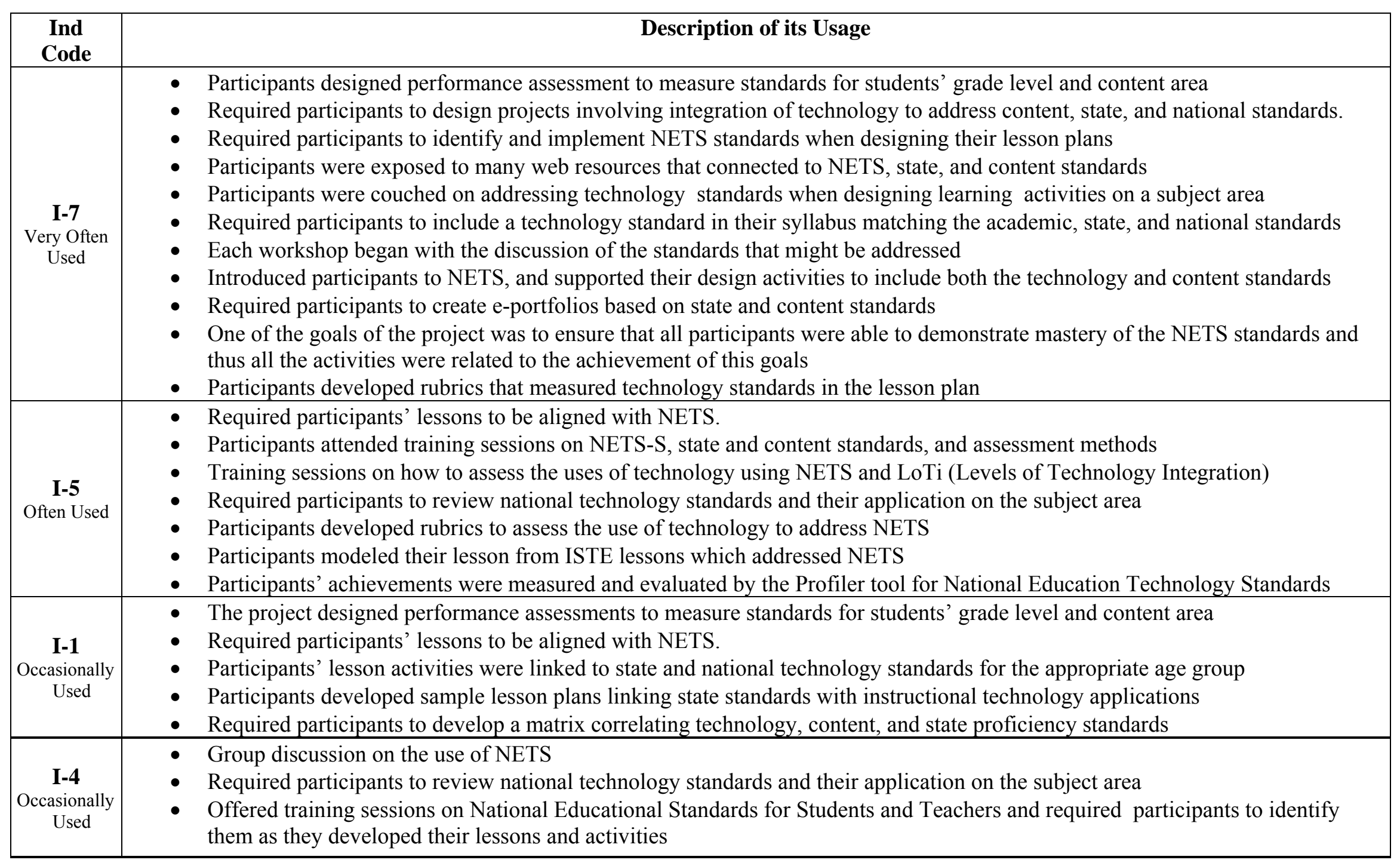


Description of the Occasionally Used Strategies across Indicators (continued)

\section{Strategy 11: Team Work/Group Discussion/Peer Discussion}

\begin{tabular}{|c|c|}
\hline $\begin{array}{c}\text { Ind } \\
\text { Code }\end{array}$ & Description of its Usage \\
\hline - This strategy did not have any indicator in which it was highly used, but this strategy was present in almost all the indicators in \\
some degree
\end{tabular}

\section{Strategy 18: Collaborative Learning}

\begin{tabular}{|l|l|}
$\begin{array}{c}\text { Ind } \\
\text { Code }\end{array}$ & Description of its Usage \\
- & $\begin{array}{l}\text { This strategy did not have any indicator in which it was highly used, but this strategy was present in almost all the indicators in } \\
\text { some degree }\end{array}$ \\
\hline
\end{tabular}




\title{
KARLAR . ASSIS, Ed.D
}

\author{
e-mail: kakaher@yahoo.com
}

\section{SUMMARY OF QUALIFICATIONS}

- 9 years of teaching experience from which 4 years were in Brazil and 5 years were in the USA

- Strong love and commitment to teaching

- Particular strength in bridging cultural gaps among people through educational and interpersonal relations

- Teaching experience for all age groups. Experience in Teaching English as a Second/ Foreign Language (TESO L/ TEFL) and experience in guiding faculty members on the use of technology for instructional purpose

\section{EDUCATION}

2001-2004

West Vinginia University

U.S.A - Morgantown, $\mathrm{WV}$

- Doctoral Degree - Ed.D, Technology Education - Minor : Instructional Technology

D issertation Topic:: Strategies for Sustainable Professional Development Programs to Promote Effective Pedagogical Use of Technology in Teaching

\section{8-2001}

West Vinginia University

- MA, Technology E ducation - Minor: Instructional Technology

U.S.A - Morgantown, $W V$

Thesis Topic: Fourth Grade Elementary Students' Perception of the Motivational Aspects of Using Computers to Write in the "Student as Authors" Project

1992- 1995

Universidade Federal do Espinito Santo

- B.A. English Language and Literature.

Brazil- Vitonia, $E S$

\section{PROFESSIONAL EXPERIENCE}

2002-present

Teaching and Leaming Technologies Center West Vinginia University

Teaching and Instructional Technology Support

- D eveloped a web page for West Virginia Partnership for Teacher Q uality - WVPTQ

- Trained students and faculty at College of Human Resources and Education on how to use different instructional technologies

- Supported the creation of e-portfolios by College of Human Resoucers and Education students

- Acted as a technology resource person to faculty and students at the College of Human Resources and Education

- Conducted workshops and prepared the tutorials for a variety of software such as Inspiration, FrontPage, and D reamWeaver.

- Assisted in the teaching of the graduate course SPED 609 Computer Application in Special Education 
June 2002-August 2002

Trek 21- Grant funded Project

U.S.A - Morgantown, $W V$ Educating Teachers as Agents of Technological Changes- West Virginia University Teaching and Instructional Technology Support for K-12 teachers and H uman Resources Education faculty members

- Presented examples of the integration of instructional technologies into teaching

- Demonstrated how to use such instructional technologies as voice e-mail, voice web board, and audio/ video instructional tools

- Guided the development of units integrating instructional technologies by K-12 and faculty members participating in the project

- Guided the decision making process of the implementation of the instructional technologies into the particpants' lesson plans

1998- May 2002

Intensive English Program

U.S.A - Morgantown, $\mathrm{WV}$

West Virginia University

Designer of a partial online course and Coordinator/ Creator of the E nglish as a Second Language Tutoring Program

- D esigned and co-created the partial online course ESL 250 Listening and Speaking skills

- Created and coordinated the Tutoring Program

- D eveloped materials and trained teachers for the tutoring program

August 1997- November 1997

Central Elementary School

U.S.A - Morgantown, $\mathrm{WV}$ Asssistant of Title I Reading Specialist

- Tutored English as a Second Language to elementary school students

- Used e-books and e-mailing to guide the reading and writing of English as a Second Language students

- Participated on the "Student as Authors" Project

August 1996- July 1997

Prefeitura Municipal de Vitonia

Brazil - Vitonia, ES

Coordinator of the Computer Lab

- Coordinated the computer lab activities

- Trained teachers and students on the development of basic computer skills

- Supported teachers to develop projects to integrate technology to their teaching

1994- July 1996

Point Language Senvices

Brazil - Vitonia, ES

English as a Foreign Language T eacher

- Taught English to children, adolescents, and adults using the communicative approach 
- Manual and instructional material resources for the Tutoring Program at West Virginia University

- Developed the online material for the ESL 250: Listening and Communication Skills course offered by the D epartment of Foreign Languages at West Virginia University

- Workshop materials used by K-12 educators and faculty at West Virginia University's College of Human Resources and Education on how to use software such as FrontPage, D reamWeaver, PowerPoint, Word, Inspiration, Audio Visual Tools, their related software, and develop instructional materials to be integrated as part of their classroom

- Tutorials to be used to instruct participants of the Instructional Technology Training Programs offered by the department of Human Resources and Education.

\section{PRESE NTATIONS}

- Assis, K. R., Dingess, T., \& Huntley, H. (April, 2002). IE P Tutoring Fills the G ap. Presentation at the International TESOL Convention. Salt Lake City, Utah.

- Assis, K. R., Dingess, T., \& Huntley, H. (April, 2002). E SL Speaking and Listening online? Presentation at CALL Internet Village - Internet Fair at the International TE SO L Convention. Salt Lake City, Utah.

- Assis, K. R. (2001). Tutoring at an Intensive English Program. Three Rivers TESOL. West Virginia, Morgantown.

- Presentations on the online course material of the ESL 250: Listening and Communication Skills course offered by the D epartment of Foreign Languages at West Virginia University.

\section{PUBLICATIONS}

\section{Dissertation}

Cezarino, K. R. A.(2004). Strategies for sustainable professional development programs to promote effective pedagogical use of technology in teaching. Unpublished doctoral dissertation, West Virginia University, West Virginia.

Thesis

Assis, K. R. (2001). Fourth grade elementary students' perception of the motivational aspects of using computers to write in the "Student as Authors" Project. Unpublished master's thesis, West Virginia University, West Virginia.

\section{Published Article}

Assis, K. R. (2001). Tutoring program at West Virginia University Intensive English Program. Three Rivers Tesol,10, 8.

\section{LAN GUAGES}

Portuguese (native), English (fluent), Spanish (working knowledge) 